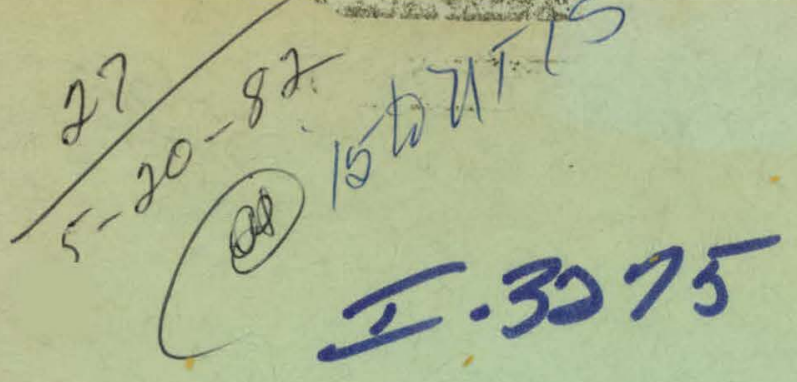

UCID- 19303

\title{
RESEARCH RESULTS REPORTED BY OEQ SUMMER \\ (1981) STUDENT EMPLOYEES OF LLNL WORKING WITH EARTH SCIENCES (K) DIVISTON PERSONNEL
}

Marianne C. Doyle, Phoebe J. Griffith, Edith P. Kreevoy, Howard J. Turner III, Debra A. Tatman

H. A. Tewes, Editor

This is an informal report intended primarily for internal or limited external distribution. The opinions and conclusions stated are those of the author and may or may not be those of the Laboratory.

Work performed under the auspices of the U.S. Department of Energy by the Lawrence Livermore Laboratory under Contract W-7405-Eng-48. 


\section{DISCLAIMER}

This report was prepared as an account of work sponsored by an agency of the United States Government. Neither the United States Government nor any agency Thereof, nor any of their employees, makes any warranty, express or implied, or assumes any legal liability or responsibility for the accuracy, completeness, or usefulness of any information, apparatus, product, or process disclosed, or represents that its use would not infringe privately owned rights. Reference herein to any specific commercial product, process, or service by trade name, trademark, manufacturer, or otherwise does not necessarily constitute or imply its endorsement, recommendation, or favoring by the United States Government or any agency thereof. The views and opinions of authors expressed herein do not necessarily state or reflect those of the United States Government or any agency thereof. 


\section{DISCLAIMER}

Portions of this document may be illegible in electronic image products. Images are produced from the best available original document. 
Abstract. $. \ldots \ldots \ldots \ldots \ldots \ldots \ldots \ldots \ldots \ldots \ldots \ldots \ldots \ldots \ldots \ldots \ldots \ldots, 1$

Introduction........................................... 2

Background.............................................. 2

Personnel.................................................. 3

Report 1--Marianne C. Doyle.................................. 6

Part I. Spent Fuel Test--Climax Stock: Core Logging Results

Part II. Calculational Test of Theory of Overburden Subsidence

Report 2--Phoebe J. Griffith............................. 23

Part I. Spent Fuel Test--Climax: Core Logging Results

Part II. Possible Southern Extension of Greenville Fault System

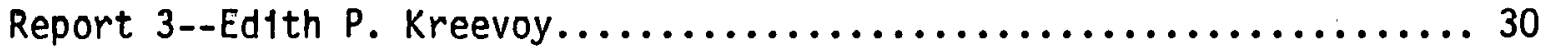

Studies in Bacteriological Purification of Water from UCG Experiment in Wyoming

Report 4--Howard J. Turner III .......................... 45

Hazardous Waste Literature Review

Report $5--$ Debra A. Tatman................................ 55

Part I. Seismic Noise in the USSR

Part. IT. Correlation of Seismir. Signal with Explosion Yield

Part III. Ground Motion Recorded in Vicinity of Underground Coal Gasification Experiment

Appendix A (to Report $1--$ Doyle) $\ldots \ldots \ldots \ldots \ldots \ldots \ldots \ldots \ldots \ldots \ldots \ldots$. Al

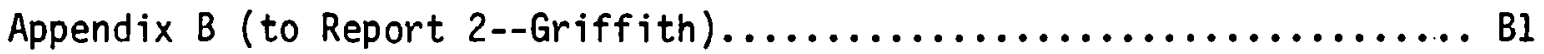

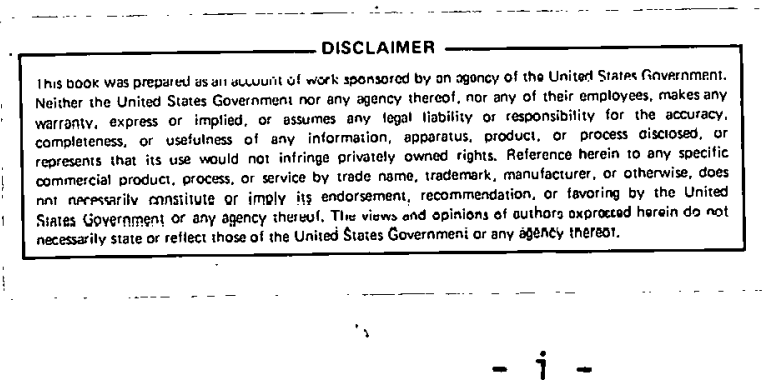

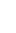
(1) 6 
RESEARCH RESULTS REPORTED BY OEO SUMMER (1981) STUDENT EMPLOYEES

OF LLNL WORKING WITH EARTH SCIENCES (K) DIVISION PERSONNEL

H. A. Tewes, Editor

ABSTRACT

Significant experimental results were achieved in a number of research programs that were carried out during the summer of 1981 by students sponsored by the Office of Equal Opportunity at the Lawrence Livermore National Laboratory. These students were working with Earth Sciences (K) Division personnel. Accomplishments include the following:

- Preparation of post-burn stratigraphic sections for the Hoe Creek III experiment, Underground Coal Gasification Project.

- Preparation of miscellaneous stratigraphic sections in the Climax granite near the Spent Fuel Test, Nevada Test Site, for the Waste Isolation Project.

- Confirmation of the applicability of a new theory relating to subsidence (solid matrix movement).

- Experimental confirmation that organic groundwater contaminants produced during an underground coal gasification experiment can be removed by appropriate bacterial treatment.

- Development of data supporting the extension of the Greenville Fault Zone into the Northern Diablo Range (Alameda and Santa Clara Counties, California).

- Completion of a literature review on hazardous waste (current disposal technology, regulations, research needs). 
- Preparation of a map showing levels of background seismic noise in the USSR.

- Demonstration of a correlation of explosion size with the P-wave magnitude of the seismic signal produced by the explosion.

- Reduction of data showing the extent of ground motion resulting from subsidence in the vicinity of the Hoe Creek III experiment, Underground Coal Gasification Project.

\section{INTRODUCTION}

This document presents brief reports of the research completed during the summer of 1981 by five of the six students who were employed under the Lawrence Livermore National Laboratory's Office of Equal Opportunity (OEO) programs and who worked with Earth Sciences (K) Division personnel. The reports have been lightly edited to conform to LLNL publishing guidelines, but, basically, the reports are representative of the research and writing capabilities of the individual students.

\section{BACKGROUND}

The objectives of the Lawrence Livermore National Laboratory's affirmative action programs are: (a) to ensure that members of groups who in the past may have been victims of employment discrimination are given equal opportunities to compete for jobs and to have their qualifications assessed fairly, and (b) to achieve a diversified work force at all levels. To implement this policy, the Laboratory's OEO has initiated a number of programs; the students whose work is reported in this document were employed under the provisions of either (1) the Summer Student Internship Program (SSIP) or (2) the Student Technology Experience Program (STEP). The SSIP 
provides full-time degree-related summer employment to college students and college-bound high school students. The program acquaints students with Laboratory expertise, facilities, and research equipment. Students work full-time for 12 weeks. The STEP provides local high school and college students with work experience relevant to their academic goals. Students work full-time during the summer and 16 hours per week during the academic year.

A key factor in the successful implementation of the OEO programs is the Affirmative Action Coordinator (AAC) at the Division level. The Earth Sciences (K) Division AAC for the past two years has been Ellen Raber. Without her continued active help and interest, the productivity of these OEO students would have been severely impaired, and the preparation of this report would not have been possible.

\section{PERSONNEL}

(Note that the year in college listed for each student will represent his or her status for the 1981-1982 academic year.)

1. Under SSIP

Marianne C. Doyle: Senior geology and mathematics major at Lafayette College, Easton, PA. Worked with Dale G. Wilder (Engineering . Geology Group) and Dr. Donald C. Helm (Geohydrology and Environmental Studies Group).

Phoebe J. Griffith: Senior geology major at Lafayette College, Easton, PA. Worked with Dale G. Wilder, David W. Carpenter (Engineering Geology Group) and Jerry J. Sweeney (Applied Geophysics Group). 
Edith P. Kreevoy: Senior civil engineering major at the University of Wisconsin, Madison, WI. Worked with Dr. Willard A. Murray (formerly of the Geohydrology and Environmental Studies Groups, now employed by Dames and Moore, San Francisco, CA), Ellen Raber (Geochemistry Group) and Dr. Daniel H. Stuermer (Environmental Sciences Division).

Kelly A. Look: Freshman at Stanford University, Stanford, CA. Worked with Prof. Albert T. Smith, Jr., and Dr. David B. Harris (Near Field Seismology Group) and Dr. Steven R. Taylor (Far Field Seismology Group). Since most of Ms. Look's work involved data processing, she did not prepare a summary report. She was assigned and completed the following tasks:

- Reading digital cassette tapes for portable seismometers into computer files.

- Compiling and organizing some 10,000 seismic P-wave arrival-time readings.

- Estimating back-azimuth of seismic events using three-component digital seismic data.

0 In the course of her 12-week appointment, Ms. Look also taught herse if the basics of FORTRAN and the Primos operating system, and wrote plotting routines to show the relationship between different parameters.

Howard J. Turner, III: Junior civil engineering major at Carnegie-Mellon University, Pittsburg, PA. Worked with David W. Carpenter, Ellen Raber, and Neil B. Crow (Geology Group). 
2. Under STEP

Debra A. Tatman: Senior geology major at California State University Hayward, Hayward, CA. Worked with Dr. Peter W. Rodgers (Applied Geophysics Group), Dr. Jean L. Younker (Geology Group), and Abelardo L. Ramirez (Engineering Geology Group). 
REPORT 1 -- Marianne C. Doyle

PART I. SPENT FUEL TEST--CLIMAX STOCK: CORE LOGGING RESULTS

PART II. CALCULATIONAL TEST OF THEORY OF OVERBURDEN SUBSIDENCE

This summer I worked in two totally different fields of geology. The first was geological engineering with Dale Wilder and the second involved geohydrologic studies with Donald Helm.

My work with Dale Wilder related to two different projects: the underground coal gasification (UCG) Hoe Creek III experiment, and the nuclear waste isolation study of the Climax granite (i.e., the Spent Fuel Test--Climax) at the Nevada Test Site. In the Hoe Creek III UCG experiment, I was involved in drafting the stratigraphic section and the accompanying geologic description from the field notes of the Post Burn Core (PBC) and Post Burn Slant (PBS) holes. I was involved in finding errors in the digitization of the electric logs (gamma, spontaneous potential (SP), density, and resistivity (E) logs 16 and 64) and ordering the corrections. In addition, I proofread the typing of the geologic descriptions.

In the Spent Fuel Test--Climax (SFT-C) at the Nevada Test Site (Ramspott et a1., 1981), the cores of ten 16-ft-deep heater holes in the south drift were logged. Core logging included mapping the location of the joints in the quartz monzonite and describing the mineralogy with any accompanying alteration in the joints. The total amount of core logged was roughly 165 ft. Core logs are included in Appendix A. 
The bulk of my work involved helping to test Donald Helm's theory of solid matrix movement (1981a, 198 lb). Since I had no previous experience in geohydrology, the first two weeks were spent as an orientation to the basics through readings from M.K. Hubbert (1940), D.K. Todd (1959), and D.W. Taylor (1948). By this time, an HP9821A calculator and 9862A plotter had arrived and I started to learn to program the calculator from the manual (Hewlett-Packard, 1973). To test my ability to program, I was given the consolidation theory of soil mechanics (Taylor, 1948, p. 234):

$$
U=1-\underset{m=0}{m} \frac{\infty}{M^{2}} e^{-M^{2} T}
$$

where $M=\frac{1}{2} \pi(2 m+1)$

$U$ is the average consolidation ratio

$T=c_{V} t / H^{2}$

where $c_{V}$ is the coefficient of consolidation

$t$ is time

$H$ is the length of the longest vertical drainage path of water which was solved and plotted successfully.

My next assignment involved verifying Donald Helm's (1981a, 1981b) new theory of calculating solid matrix movement of a saturated confined aquifer system in response to fluid withdrawal. This theory can be applied to any time-dependent solid/fluid interaction in sedimentary material. For example, it predicts horizontal and vertical components of subsidence associated with fluid production, including water, oil, gas, geothermal/geopressured brine, and geothermal steam. The old theory (Biot, 1941; Bear and Corapcioglu, 1981) involves a three-step strategy. The first step solved for time-dependent stress, the second step for time-dependent strain, and, finally, the third for time-dependent displacement of the 
solids. One problem with this theory is trying to get from the second to the third step in the field. It is difficult to predict how the shape of a specified group of particles has changed in response to the change in stress. The new theory reverses the sequence and solves first for the time-dependent displacement of the solid matrix and then for the time-dependent stress and strain.

My work involved verifying the new theory by comparing the solutions for stress based on the old theory with solutions for stress based on the new theory. The tentative solution for axially symmetric vertical displacement according to the new theory is

$$
\begin{aligned}
& U_{z d}=-2 \sum_{n=1}^{\infty} \frac{1}{N^{3}}(\sin N) e^{-N^{2} T} \\
& +\frac{1}{2}\left\{1+A\left[\left(\ln R_{d}\right)+2 \sum_{m=1}^{\infty} \frac{J_{1}\left(\beta_{m} R_{d}\right)}{\beta_{m}^{3} J_{1}^{2}\left(\beta_{m}\right)} e^{-\beta_{m}^{2} T}\right]\right\} \\
& +4 A\left[\sum_{n=1}^{\infty} \frac{1}{N^{3}}(\sin N) e^{-N^{2} T}\right]_{m=1}^{\infty} \frac{1-e^{-\left(\beta_{m}{ }^{2}-N^{2}\right) T}}{\left(\beta_{m}^{2}-N^{2}\right)}
\end{aligned}
$$

where $\quad N=\frac{(2 n-1) \pi}{2}$

$$
u_{z d}=\frac{k_{z z} u_{s z}}{s_{s} z^{2} v_{s z i}}
$$

$U_{S Z}$ is the vertical component of displacement field of solids.

$K_{Z Z}$ is the vertical component of a transversely isotropic hydraulic conductivity tensor.

$S_{S}$ is the specific storage for volumetric skeletal strain. 
$Z$ is the thickness of aquifer system.

$V_{\text {szi }}$ is the initial value of the vertical component of the velocity field of solids.

$\mathrm{U}_{\mathrm{Zd}}$ is the normalized vertical displacement of the upper boundary of a reservoir.

$A$ is a function of the anisotropy of the transversely isotropic system $(0 \leq A \leq 1)$ and was set equal to one.

$R_{d}$ is the normalized radial distance from the production well. $R_{d} \equiv r / R \geq 0$, where $r$ is the radial distance to a point of interest and $R$ is a radius of influence that is determined by $Z$ and by the degree of anisotropy of the aquifer system.

$B_{n}$ is the nth root of the Bessel equation $J_{0}\left(B_{m}\right)=0$.

Figure 1-1 is a plot of the solution given above. However, the plot does not include the third term of the function. My assignment was to determine how significant an effect the previously uncalculated third term had on the solution. My calculations indicated that the values for the third term were sufficiently small such that they had little effect on the plot. Figure 1-1 thus indicates that the vertical component of displacement, $U_{z d}$, moves downwards with time ( $i$. e., that subsidence - increases with time). Note that $U_{z d}$ in the foregoing equation pertains only to the upper boundary of a reservoir.

It may be that the third term is significant in an equivalent equation for vertical displacement of a surface near the base of a reservoir. These values have not yet been plotted. 


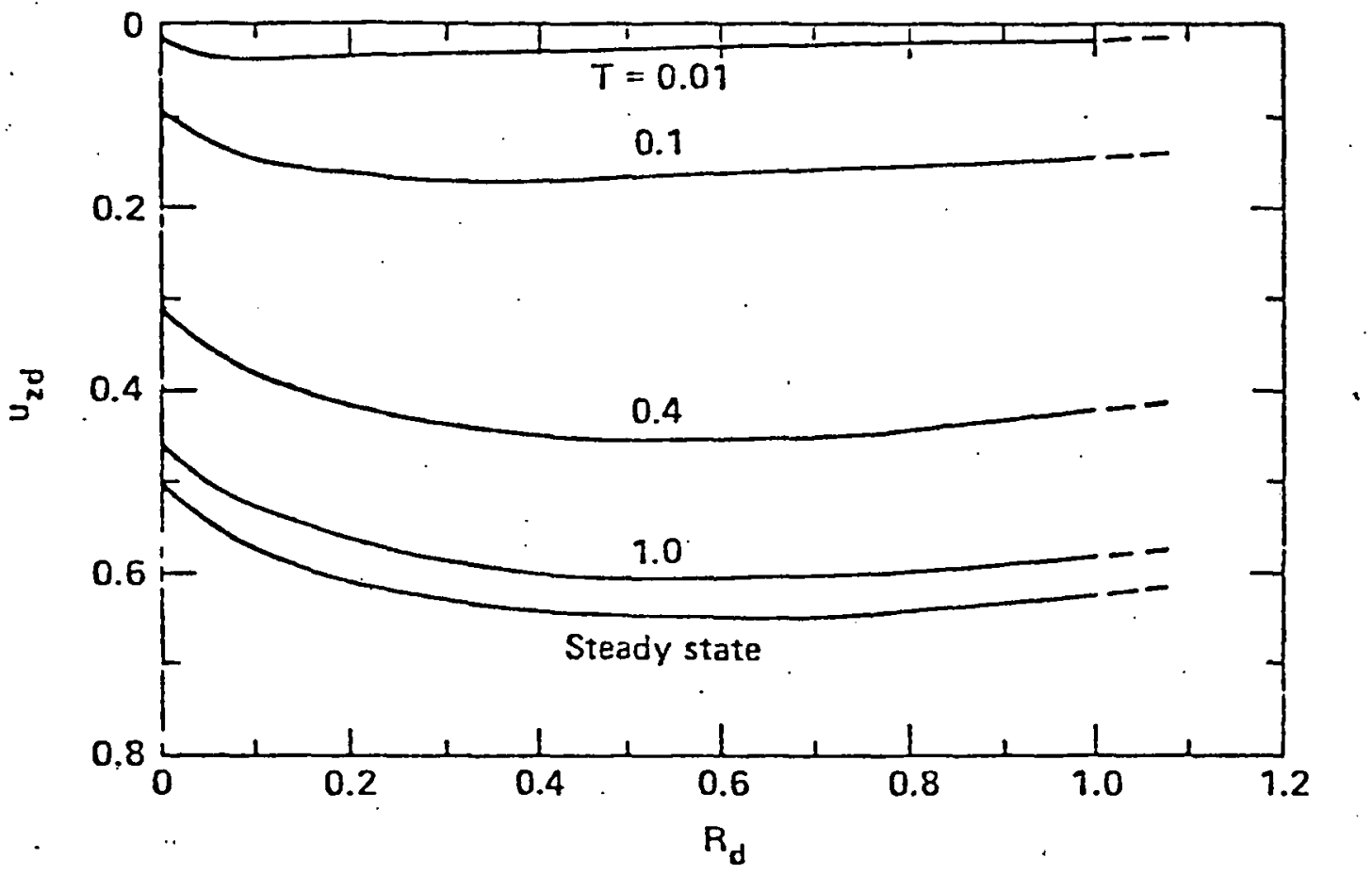

Figure 1-1. Vertical component of dimensionless displacement $U_{z d}$ vs normalized radial distance $R_{d}$ from the production well for different values of dimensionless time $T$. 
14 I was also asked to calculate the third term in the equation

$$
\begin{aligned}
& E_{z z}=2 \sum_{n=1}^{\infty} \frac{1}{N^{2}}\left\{\cos \left[N\left(1-z_{d}\right)\right]\right\} e^{-N^{2} T} \\
& -Z_{d}\left\{1+A\left[1 n R_{d}+2 \sum_{m=1}^{\infty} \frac{J_{1}\left(\beta_{m} R_{d}\right)}{\beta_{m}^{3} J_{1}^{2}\left(\beta_{m}\right)} e^{-\beta_{m}^{2} T}\right]\right\} \\
& +4 A\left\{\sum_{n=1}^{\infty} \frac{1}{N^{2}} \cos \left[N\left(1-Z_{d}\right)\right] e^{-N^{2} T}\right\} \sum_{m=1}^{\infty} \frac{1-e^{-\left(\beta_{m}^{2}-N^{2}\right) T}}{\left(\beta_{m}^{2}-N^{2}\right)} \\
& \text { where } E_{z z} \equiv \frac{k_{z z} E z z}{S_{s} Z v_{s z i}}
\end{aligned}
$$

$E_{Z z}$ is the vertical normal component of the strain tensor.

$z_{d}(\equiv z / Z)$ is normalized depth within the bounds $0 \leq Z_{d} \leq 1$.

$z$ is the depth to a point of interest below the upper boundary of the aquifer system.

$Z$ is the depth to the upper bound of zero vertical movement that underlies the system.

I was then to determine if this third term had any appreciable effect on the computed value of the equation as a whole. Near the top of the reservoir $\left(z_{d}=0\right)$, the term was negligibly small.

Figure 1-2 is a plot of dimensionless pressure vs dimensionless time for $Z_{d}=0$ at different radial distances from a production we 11 . This plot indicates that there is more drawdown near the well than exists farther away and that the drawdown increases with time. The solid lines (new theory) compare closely to Hantush and Jacob's (1955) initial theory of leaky aquifers. The dashed line in the figure shows the shape of Theis' (1935) pioneering theory. This strongly helps to validate the new theory. The 


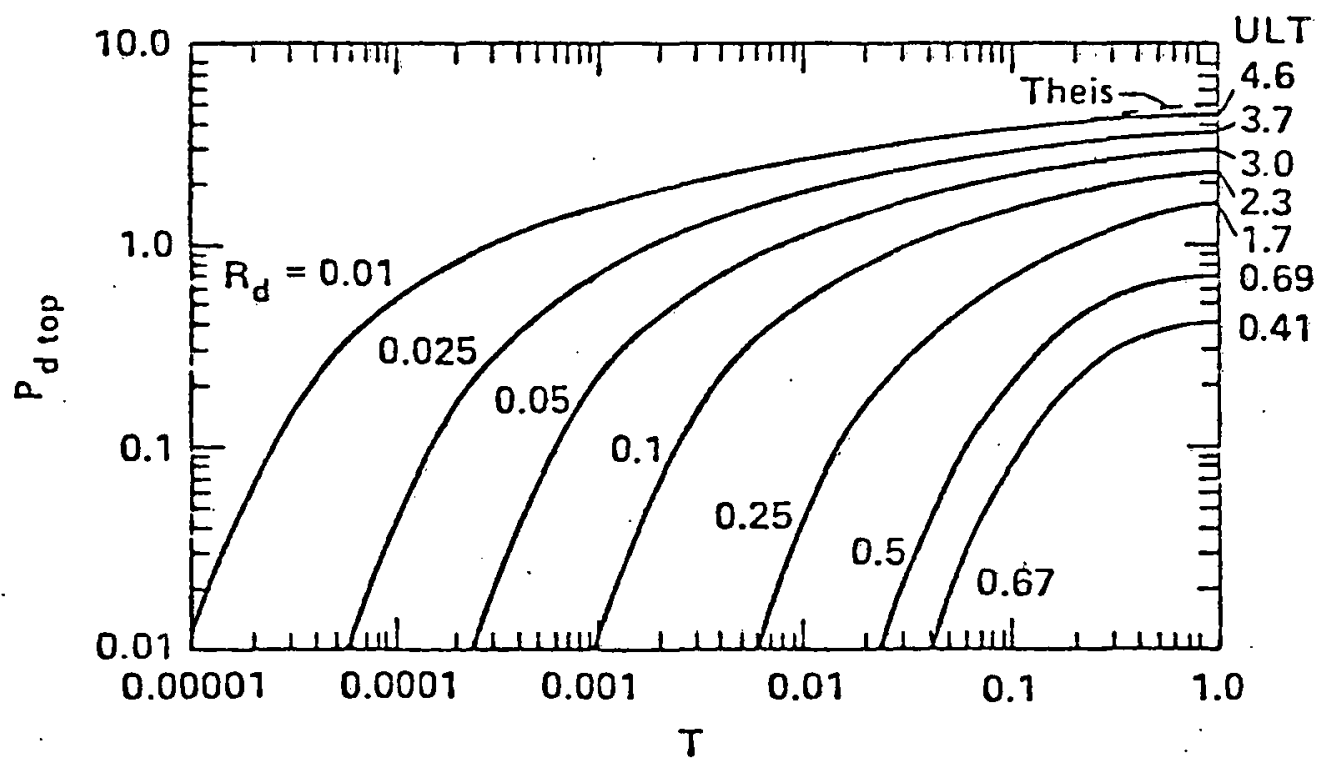

Figure 1-2. Dimensionless pressure at the top of a confined aquifer $P_{d}$ top vs dimensionless time $T$ at different nornialized radial distances $R_{d}$ from the production well. 
significance of the third term for surfaces near the base of a reservoir $\left(Z_{d}=1\right)$ has not yet been determined.

The following addendum contains the two programs written for the third terms of the equations $E_{z z}$ and $U_{z d}$ along with a description of the logic used., 


\section{ADDENDUM}

The purpose of this addendum is to explain the logic invoived in the two programs used to calculate the third terms of the equations:

\section{PROGRAM 1}

$$
\begin{aligned}
& U_{z d}=-2 \sum_{n=1}^{\infty} \frac{1}{N^{3}} \quad(\sin N) e^{-N^{2} T}
\end{aligned}
$$

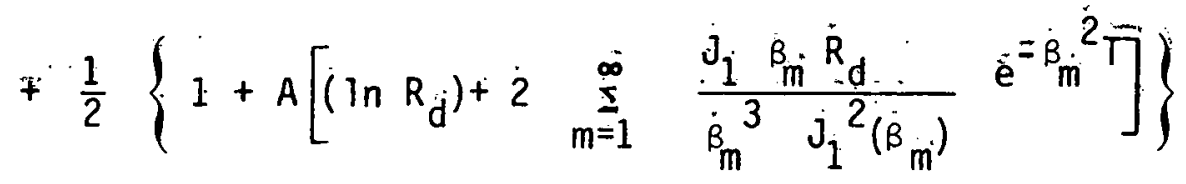

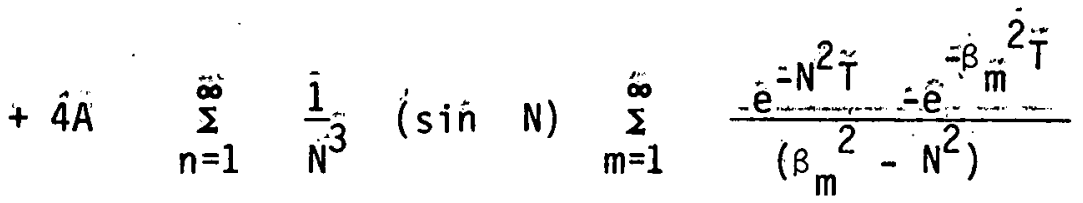

where $\quad A=1$ and $N=\frac{(2 \dot{n}-1) \pi}{2}$.

\section{PROGRAM 2}

$$
\begin{aligned}
& E_{i i^{\prime}}=2 \sum_{n=1}^{\infty} \frac{1}{N^{2}}\left\{\cos \left[N\left(1-Z_{d}\right)\right]\right\} e^{-N^{2} T} \\
& -Z d\left\{1+A\left[\ln R_{d}+2 \sum_{m=1}^{\infty} \frac{J_{1}\left(\beta_{m} R_{d}\right)}{\beta_{m}^{3} j_{1}^{2}\left(\beta_{m}\right)} e^{-\beta_{m}^{2} T}\right]\right\}
\end{aligned}
$$

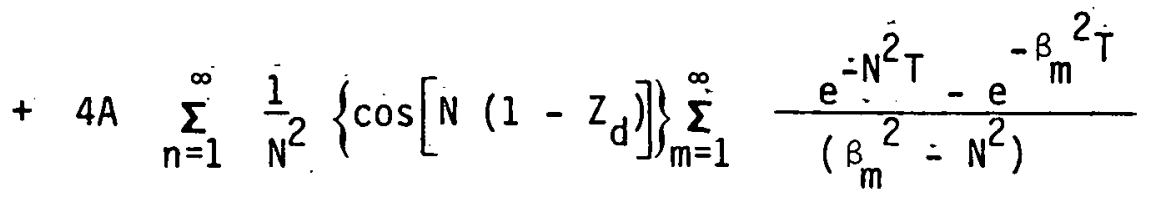


Step

$$
\begin{aligned}
0: & 0 \rightarrow X \rightarrow Y \rightarrow A \rightarrow B \rightarrow C \rightarrow R 15 \rightarrow \\
& R 16, \rightarrow R 17 ; 1 \rightarrow Z ; \text { ENT R13 }
\end{aligned}
$$

Initializes registers $X, Y$, $Z, A, B, C, R 16$ and counters R15 and R17. Enters time factor.

$1: \quad 2.4048255577 \rightarrow \mathrm{Rl}$;

$5.5200781103 \rightarrow R 2$;

$8.6537279129 \rightarrow R 3+$

$2: 11.7915344391 \rightarrow R 4$;

$14.9309177086 \rightarrow R 5$;

$18.071063967 \rightarrow R 6 F$

$3: 21.2116366299 \rightarrow R 7$;

$24.3524715308 \rightarrow \mathrm{R} 8$;

$27.4934791320+R 9+$

$4: 30.6346064684 \rightarrow R 10$;

$33.7758202136 \rightarrow R 11$;

$36.9170983537 \rightarrow R 12 \vdash$

$5: \pi(2 x-1) / 2 \rightarrow Y+$

$6: R Z \uparrow 2-Y \uparrow 2 \quad A+$

7 : If $Y \uparrow 2$ R13 > 80; GTO "A"-

8 : If $R Z \uparrow 2$ RI3 > 80; GTO "A"-

$9:(\operatorname{EXP}(-Y+2 \quad R 13)-$

$\operatorname{EXP}(R Z \uparrow 2 \quad R 13)) / A \rightarrow B$

Puts values for $\beta_{m}$ (the root that solves the Bessel function, $\left.J_{0}\left(\beta_{m}\right)=0\right)$ in registers R1 through R9.
Puts the value for $N$ in register $Y$.

Puts the value for $B_{m}{ }^{2}-N^{2}$ $(m=1$ to 12$)$ into register $A$.

Prevents the calculation for the term that occurs in step 9 from getting out of the calculation range.

Puts the value for

$\frac{\left(e^{-N^{2} T}-e^{-\beta_{m}{ }^{2} T}\right)}{\left(\beta_{m}{ }^{2}-N^{2}\right)}$

into register $B$. 
$10: B+C \rightarrow C$; IF $R I 5=11 ;$ GTO "A" $\downarrow$

$11: 1+R 15 \rightarrow R 15 ;$ GTO 5 ト
Sums up all the

$\frac{e^{-N^{2} T}-e^{-\beta_{m}^{2} T}}{\beta_{m}^{2}-N^{2}}$

up to the $12^{\text {th }}$ term--if you have summed all of the terms, it sends the data to "A". If not, it goes to the next $\beta_{m}$ and returns to 5 to recalculate.

Calculates

$\frac{1}{N^{3}} \sin N \sum_{m=1}^{\infty} \frac{e^{N^{2} T}-e^{-\beta} m^{2} T}{B_{m}^{2}-N^{2}}$

and sums them all up into register $R 16$. It also includes $180 / \pi$ as a conversion factor for the calculator, which handles trigonometric functions in degrees, no tradians.

Checks counter so that the total amount of terms added up does not exceed the amount of $B_{m}$ 's (in this case 12). When it has reached the right amount, it sends the computer out of the loop to step 15 . '

Increments the counter for $\mathrm{n}$ and increments, the counter for $m$ and sends the computer back to step 5 and the first loop. 
15 : PRT " $X "=, 4 R 16, " T=", R 13$,

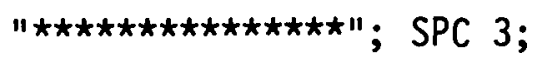

$+\quad$ ENT R13F

$16: \quad 0 \rightarrow X \rightarrow Y \rightarrow A \rightarrow B \rightarrow C \rightarrow R 15 \rightarrow$ $\mathrm{R} 16 \rightarrow \mathrm{R} 17 ; 1 \rightarrow \mathrm{Z}$; GTO 1 F

$\star \star \star \star$ (Loop is steps 12 to 16 )

$17:$ END
Prints value for $U_{z d}$, the time factor, spaces 3 then asks for a new time factor.

Initializes both registers $X, Y, Z, A$, $B, C, R 16$, and counters $R 15$ and R17. Send data back to step 1 to calculate another $U_{z d}$. 
Step

$$
\begin{array}{ll}
0: \quad 0 \rightarrow X \rightarrow Y \rightarrow A \rightarrow B \rightarrow C \quad R 15 \rightarrow & \text { Initializes registers } X, Y, \\
R 16, \rightarrow R 17 ; 1 \rightarrow Z ; \text { ENT R13 } & \text { Z, A, B, C, R16 and counters } \\
& \text { R15 and R17. Enters time factor. }
\end{array}
$$

$1: \quad 2.4048255577 \rightarrow R 1$;

$5.5200781103 \rightarrow R 2$;

$8.6537279129 \rightarrow R 3+$

2 : $11.7915344391 \rightarrow R 4$;

$14.9309177086 \rightarrow R 5$;

$18.071063967 \rightarrow R 6+$

$3: 21.2116366299 \rightarrow R 7$;

$24.3524715308 \rightarrow R 8$;

$27.4934791320 \rightarrow R 9+$

$4: 30.6346064684 \rightarrow \mathrm{R} 10$;

$33.7758202136 \rightarrow R 11$;

$36.9170983537 \rightarrow R 12 \nmid$

$5: \quad \pi(2 x-1) / 2 \rightarrow Y \mid$

Puts values for ${ }^{B} m$ (the roots that satisfy the Bessel function, $\left.J_{0}\left(B_{m}\right)=0\right)$ in registers

R1 through R9.

$6: R Z \uparrow 2-Y \uparrow 2 \rightarrow A \vdash$

7 If $Y \uparrow 2 * R 13>80$; GTO "A"

8 : If $R Z \uparrow 2$ * $R 13>80$; GTO "A"

$9: \quad\left(\operatorname{EXP}\left(\begin{array}{lll}-Y+2 & R 13)-\end{array}\right.\right.$ $\operatorname{EXP}(R Z \uparrow 2 \quad R 13)) / A \rightarrow B+$
Puts the value for $N$ in register $Y$.

Puts the value for $B_{m}{ }^{2}-N^{2}$ $(m=1$ to 12$)$ into register $A$

Prevents the calculation for the term that occurs in step 9 from getting out of the calculation range

Puts the value for $\frac{\left(e^{-N^{2} T}-e^{-\beta_{m}{ }^{2} T}\right)}{\left(\beta_{m}{ }^{2}-N^{2}\right)}$

into register $B$. 
$10: B+C \rightarrow C ;$ IF R15=11; GTO "A"

Sums up all the

$11: 1+R 15 \rightarrow R 15 ;$ GTO 5 ト $\frac{e^{-N^{2} T}-e^{-\beta_{m}^{2} T}}{\beta_{m}^{2}-N^{2}}$

up to the $12^{\text {th }}$ term--if you have

summed all of the terms, it sends the data to "A". If not, it goes to the next $B_{m}$ and returns to 5 to recalculate.

$\star \star \star$ (Loop is steps 5 to 11 )

$12:$ :A"; $C * Y \uparrow(-2)$

Calculates

$\star \cos (Y * 180 / \pi)+R 16 \cdot R 16+\left[\frac{1}{N^{2}} \cos N \sum_{m=1}^{\infty} \frac{e^{N^{2} T}-e^{-\beta_{m}{ }^{2} T}}{\beta_{m}^{2}-N^{2}}\right]$

and sums them all up into register R16. It also includes $180 / \pi$ as a conversion factor for the calculatpr, which handles trigonometric functions in degrees, not radians.

13 : $1 F \quad$ R17=11 ; GTO 15 P

Checks counter so that the total amount of terms added up does not exceed the amount of $\beta_{\mathrm{m}}$ 's (in this case 12).

When it has reached the right amount, it sends the computer out of the loop to step 15.

$14: 1+R 17 \rightarrow R 17 ; X+1 \rightarrow X ; 0 \rightarrow R 15$;

Increments the counter for $n$ and GTO 5 卜 increments the counter for $m$ and sends the computer back to step 5 and the first loop. 
15: PRT "X"=, 4R16, "T=", R13,

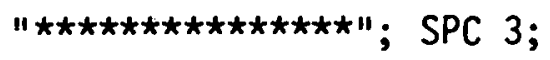
ENT R13 F

$16: 0 \rightarrow X \rightarrow Y \rightarrow A \rightarrow B \rightarrow C \rightarrow R 15 \rightarrow$ $\mathrm{R} 16 \rightarrow \mathrm{R} 17 ; 1 \rightarrow 2 ; \mathrm{GTO} 1+$

$\star \star \star \star$ (Loop is steps 12 to 16 )

17 : END
Prints value for $U_{z d}$, the time factor, spaces 3 then asks for a new time factor.

Initializes both registers $X, Y, Z, A$, $B, C, R 16$, and counters $R 15$ and R17.

Sends data back to step 1 to calculate another $U_{z d}$. 


\section{REFERENCES}

Bear, J., and Corapcioglu, M. Y., 1981, "Mathematical Model for Regional Land Subsidence due to Pumping," Water Resources Research, 17, 937-958.

Biot, M.A., 1941, "General Theory of Three-Dimensional Consolidation," $\underline{J}$. App 1. Phys., 12, 155-164.

Hantush, M. S., and Jacob, C. E., 1955, "Nonsteady Radial Flow in an Infinite Leaky Aquifer," Trans. Am. Geophys. Union, 37, 95-100.

Helm, D.C., 1981a, "Transient Drawdown Patterns Within a Confined Aquifer System Viewed in Terms of Anisotropic and Nonhomogeneous Skeletal Deformation (abs.)," Trans. Am. Geophys. Union (EOS). 62, 281.

Helm, D. C., 1981b, "Conceptual Aspects of Subsidence due to Fluid Withdrawal," Recent Trends in Geohydrology, (R.A. Freeze and T. N. Narasimhan, Eds.) Geological Society of America (in press).

Hewlett-Packard, 1973, Operating and Programming Manual for the HP9821A Calculator, Loveland, Colo., Hewlett-Packard Co., 132. p.

Hubbert, M. K., 1940, "Theory of Groundwater Motion," J. Geol., 48, $785-944$. 
Ramspott, L. D., Ballou, L. B., and Patrick, W. C., 1981, Status Report on the Spent Fuel Test--Climax: A Test of Geologic Storage of High-Level Waste in Granite, Lawrence Livermore National Laboratory Rept. UCRL-85516 (prepared for submittal to AIME Annual Meeting, Chicago, IL, February 22, 1981).

Taylor, D. W., 1948, Fundamentals of Soil Mechanics (New York, John Wiley and Sons, Inc.), $700 \mathrm{p}$.

Theis, C. V., 1935, "The Relationship Between the Lowering of Piezometric Surface and the Rate and Duration of Discharge Using Groundwater Storage," Trans. Am. Geophys. Union, 16, 519-524.

Todd, D. K., 1959, Ground Water Hydrology (New York, John Wiley and Sons, Inc.), $336 \mathrm{p}$. 
REPORT 2--Phoebe J. Griffith

PART I. SPENT FUEL TEST--CLIMAX: CORE LOGGING RESULTS

PART II. POSSIBLE SOUTHERN EXTENSION OF GREENVILLE FAULT SYSTEM

In my summer work at LLNL, I have been involved in a number of tasks, most of which come under the Site Survey Project, a geologic hazards appraisal of the LLNL site. In carrying out these tasks, I have been under the supervision of David Carpenter and Jerry Sweeney. I have done field work for a seismic refraction profile and at geohydrology drill sites and work on the Greenville Fault study, doing literature research and other in-office work. My second major task this summer has been core logging of samples from the climax granite stock at the Nevada Test Site (NTS). This work was done for the Spent Fuel Test--Climax (SFT-C) under the direction of Dale Wilder.

My field work on the seismic refraction profile lasted only three days and consisted of observing the operation and helping to lay down cables and plant geophones. My other field work consisted of the two geologic drilling and coring activities: the geohydrology study and the core logging at NTS. On the geohydrology study, I worked with David Carpenter and others at various drill sites around and on the Laboratory grounds. The drill holes are intended for groundwater monitoring purposes; samples taken at regular intervals from the cores will be used in an attempt to correlate the strata beneath the Laboratory and produce a cross section. My duties on this project were to help in sampling, to box and label samples in preparation for storage, and occasionally to add input to the description of samples. 
Spent Fuel Test--Climax

Logging of $160 \mathrm{ft}$ of core from the north heater drift (SFT-C) heater holes was completed during the last three weeks of the summer. The core was logged for the location of joints and their mineralogy, thickness, and orientation. The core logs are presented as Appendix B.

\section{Study of the Greenville Fault}

My major task this summer has involved working with Jerry Sweeney on the study of the Greenville Fault, which also falls under the Site Survey heading. The purpose of this study is to determine the actual length of the Greenville Fault by investigating the possible existence of a southern extension of this feature, identified as a lineament on air photos of the Northern Diablo Range.

After reading reports on the geology of the area surrounding the Livermore Valley to get acquainted with the rocks of this area, I began the actual task of studying the lineament. This study consisted of two main activities:

1. Review of papers dealing with the area of the lineament. This review was to determine whether the rocks on either side of the fault zone can be correlated. Of particular interest were papers by Bauder (1975) and Evarts (1977) which deal with the Cedar Mountain region and the Red Mountain region, respectively. These regions are interpreted as containing ophiolite bodies which are believed to have been a single unit at one time and have since been offset by the Greenville Fault. If these units were indeed a single body in the past, the offset indicated would be approximately $6 \mathrm{mi}(10 \mathrm{~km})$. 
2. Palinspastic reconstruction of movement along the fault, to observe the structures as they may have appeared before right lateral movement displaced the ophiolites. I performed this construction by cutting copies of maps by Cotton (1972) and Dibblee (1981) along the lineament and moving them in a left-lateral sense until the ophiolite matched up.

Not only do the rocks and structures correlate well on the maps (of Cotton and.Dibblee), but the petrography of the ophiolites (of Bauder and Evarts) correlates very well also. Table 2-1 relates the units found in the two ophiolites described by Bauder (1975) and Evarts (1977). Similarities between the two can be observed. Also included are reproductions of the map reconstructions based on Dibblee (1979). Figure 2-1 is the area as it appears now. Figure 2-2 shows the reconstruction.

Field reconnaissance of the area is planned in the future: this study is not yet completed. However, the evidence at hand points very strongly to the existence of the Greenville Fault south of the Livermore Valley. 
Table 2-1. Units found in the ophiolites described by Bauder and Evarts.

CEDAR MTN.

(BAUDER)

1 .

2. MINOR KERATOPHYRE

3. GABBROIC SECTIONS:

- DIORITES

- GABBROS: HORNBLENDE

+ PLAGIOCLASE

SOME W/ CUMULUS TEXTURE

- PLAGIOGRANITE

4. "DISMEMBERED OPHIOLITE": (SERPENTINIZED ALPINE ULTRAMAFICS)

- DUNITE W/ CHROMITE AND INTERLAYERS OF PYROXENITE

- HARZBURGITE: OLIVINE + ORTHOPYX.

- MINOR CLINOPYROXENE + CHROMIUM SP INEL

- PARTLY SERPENTINIZED
RED MTN.

(EVARTS)
1. CHERT + VOLCANICLASTIC S.S.

2. VOLCANIC MEMBER:

- ALTERED BASALTS, ANDESITES, DACITES

3. PLUTONIC MEMBER:

- HORNBLENDE QTZ. DIORITES

- HORNBLENDE GABBROS W/ PYROXENE CUMULATES

- GABBRO CUMULATES W/ PLAGIOGRANITE INTRUSIVES

4. ALPINE PERIDOTITE MEMBER:

- BLACK SERPENTINITE

- DUNITE-WEHRUTE: W/ CHROMITE AND PYROXENITE DIKES

- HARZBURgITE: OLIVINE + ORTHOPYX.

- MINOR CLINOPYROXENE + CHROMIUM SPINEL

- PARTLY SERPENTINIZED

- HIGHLY SHEARED SERPENTINITE (AT MARGINS OF MASS) 


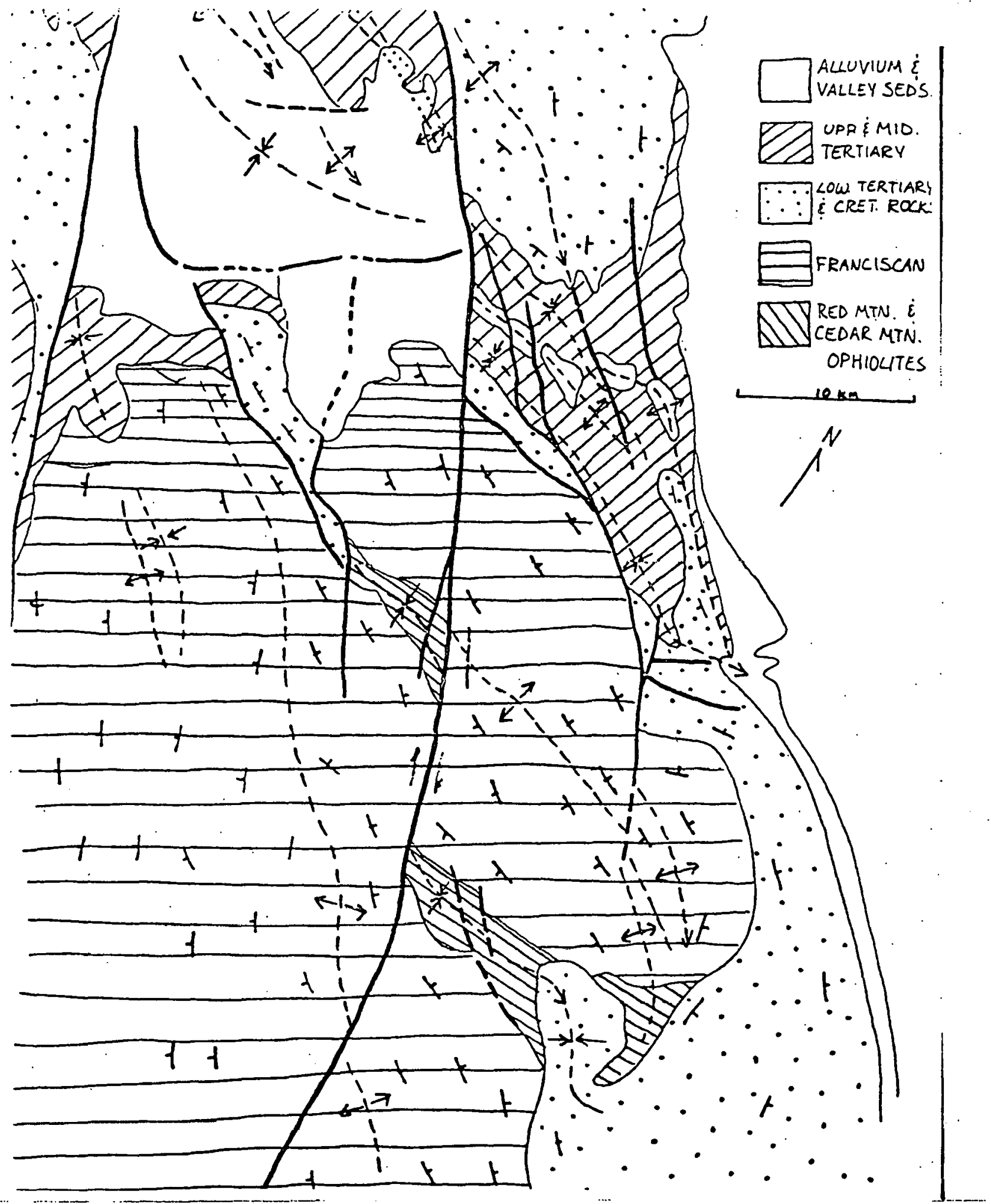

Figure 2-1. Present interpretation of structure in Southcastern Alameda County/Northeastern Santa Clara County in the Cedar Mountain/Red Mountain Regions. 


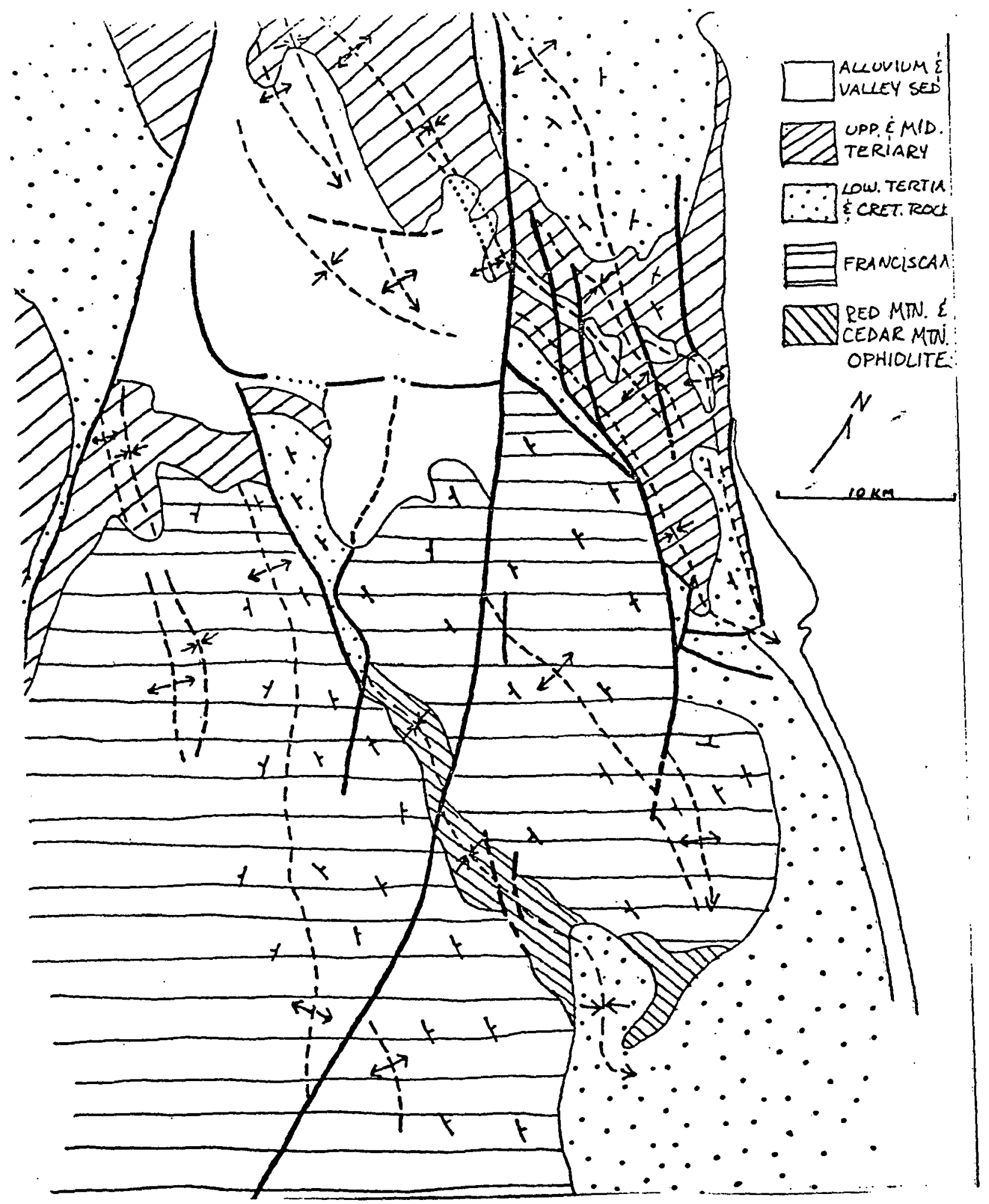

Figure 2-2. Palinspastic reconstruction of $10 \mathrm{~km}$ of dextral movement along the Greenville Fault shown in Figure 1. 


\section{REFERENCES}

Bauder, J. M., 1975, Geology of the Cedar Mountain Region Northern Diablo Range, California, M.S. Thesis, Stanford University, Stanford, CA, 93 p.

Cotton, W. R., 1972, Preliminary Geologic Map of the Franciscan Rocks in the Central Part of the Diablo Range, Santa Clara and Alameda Counties, California, U.S. Geological Survey Misc. Field Studies Map MF-343.

Dibblee, T. W., Jr., 1981, private communication.

Evarts, R. C., 1977, "The Geology and Petrology of the Del Puerto Ophiolite, Diabḷ Range, Central California Coast Ranges," in Coleman, R. G., and Irwin, W. P., Eds., North American Ophiolites, Oregon Department of Geology and Mineral Industries Bu11. 95, pp. 121-140. 
REPORT 3 -- Edith P. Kreevoy

STUDIES IN THE BACTERIOLOGICAL PURIFICATION OF WATER FROM UCG EXPERIMENT IN WYOMING

\section{Introduction}

Underground coal gasification (UCG) involves the conversion of coal into combustible gases, which are a source of synthetic fuels. If the coar is gasified underground the utilization of deep coal reserves may be economically feasible and, in addition, there is no need to expose workers to the hazards of underground mining. However, there are environmental implications as a result: of this process, one of which is the possible contamination of groundwater.

This report gives the results of a study that has been undertaken to determine if certain bacteria may be able to digest and remove the organic contaminants in the groundwater near the UCG experiments carried out at the Hoe Creek Site in northeastern Wyoming. Furthermore, the basic design of a treatment facility was formulated, and a simplified cost analysis for groundwater cleanup, based on laboratory results, was prepared.

By adding certain nutrients to the environment the growth of some bacteria can be stimulated, and if the biostimulation demonstrated in the laboratory could be achieved in the field, the resulting increases in bacterial flora should accelerate the removal of contaminarits from groundwater. In determining if the biostimulation process would stimulate the bacteria in the groundwater at Hoe Creek, several analyses were performed. Adenosine triphosphate (ATP) 
was used for measuring the actual microbial biomass, and since bacterial populations have been reported to be directly proportional to concentrations of ATP, the analysis can be directly related to the concentration of bacteria in the groundwater.

\section{Experimental}

Two water samples from the water sampling well WS-10 (located $3 \mathrm{~m}$ from the Hoe Creek II burn cavity and completed into the Felix No. 1 coal seam; see Fig. 3-1) were each filtered through Schleicher and Schell \#25 glass fiber filter papers ( 3.0 gal/filter). Each filter was divided, and each half was immediately immersed in boiling tris* buffer $(10 \mathrm{ml})$ for five minutes; and then the four 10-ml samples were frozen. To determine the ATP content, the frozen samples were thawed and $1.0 \mathrm{ml}$ of buffered firefly extract was added to $0.2 \mathrm{ml}$ of each of the samples. The resulting solutions were then placed in a JRB photometer, which was used for the quantitative determination of ATP by measuring the amount of light given off by its reaction with firefly luciferase enzyme. The bloluminescent reaction is specific for ATP. (One photon of light is emitted for each molecule of ATP that is hydrolyzed.)

Subsequent to the determination of the bacterial concentration in the Hoe Creek II water samples, nutrient analyses were carried out on duplicate water samples. Next, four different tests were performed to see which conditions would increase the number of bacterial cells per liter of Hoe Creek II

*tris: tris(hydroxymethy 1) aminomethane. 


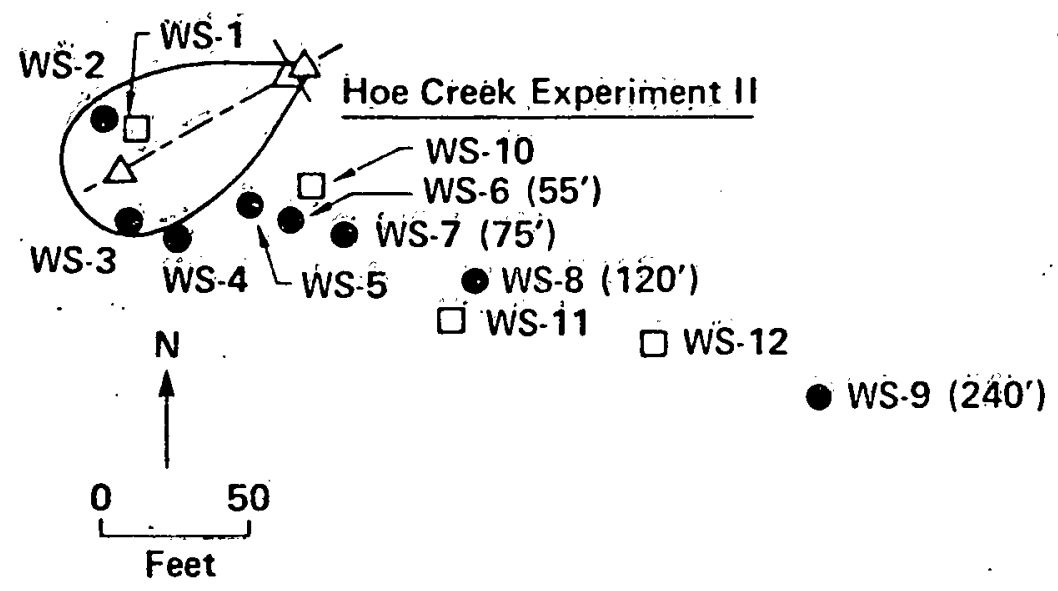

O EM.1

Site boündary
WS. 14

WS: 130

O P.O

Hoe Creek Experiment I

O 1.0

Figure 3-1. Location of water sampling wells (WS 1-14) near the Hoe Creek II gasification experiment. The process wells (open triangles) ànd wells at the Hoe Creek I site have also been sampled. The weils indicated with open squares are completed in the Felix No: 1 Coal. The solid circles designate wells completed in the Felix No: 2 Coal. Additional wells have been émpletêd in ân overlying sand aquifer. 
water:

(1) Leave water untouched in closed flask

(2) Aerate water (continuously during bacterial growth period)

(3) Aerate and add enough sodium phosphate to adjust the weight ratio of nitrogen: phosphorous to $16: 1^{*}$

(4) Aerate; add sodium phosphate as in 3 ) above*; add yeast extract $\star \star$

Eight samples (2 of each test) were treated as indicated above and placed away from light for five days. At this time each sample solution. was filtered through Schleicher and Schell \#25 glass fiber filter paper. Each filter (or set of filters) was immersed in $10 \mathrm{ml}$ of boiling tris buffer for five minutes. The ATP content of each of the resulting solutions was determined using the JRB Photometer, and the bacterial concentrations in the eight samples (four sets of duplicate samples) were calculated.

Finally, a sample of Hoe Creek II well water (with known pollutant loading) was treated with sodium phosphate (to attain an optimum nitrogen to phosphorous ratio*) and yeast extract added. The mixture was aerated in the absence of light for three weeks, and the resulting solution was analyzed to determine the effect of bacterial action on the pollutants present in the groundwater.

* But see footnote on p. 34 regarding calculational error.

* The yeast extract is a source of B-vitamins and is the water-soluble portion of fresh yeast. 


\section{Results}

To quantify the ATP analyses of the Hoe Creek II well water samples, a stock solution of ATP was made and used in serial dilutions to calibrate the JRB photometer (see Table 3-1). Based on the calibration and the analytical results for Hoe Creek II water shown in Table 3-2, the average ATP content of each of the "half-filter" samples (equivalent to $1.5 \mathrm{gal}$ of well water) was $0.088 \pm 0.010$ or $15.5 \pm 1.7 \mathrm{ng} / \overline{1}$. Using the conversion factor

$$
\text { bacterial cells/1 }=6.6 \times 10^{5} \mathrm{C}
$$

where $\dot{c}$ is ATP concentration in ng/l (Holm-Hansen and Booth, 1966), the bacterial concentration in the Hoe Creek II well water was calculated to be $(1.02 \pm 0.11) \times 10^{7} \mathrm{cells} / 1$. Since this bacterial concentration is too jow to be effective in the treatment of the well water to reduce the levels of organic pollutants, a nutrient analysis was performed on the well water so that the nitrogen to phosphorous ratio could be adjusted for optimum bacterial growth. Results of the analysis of duplicate well water samples are presented in Table 3-3. Based on the results shown in Table 3-3, the ratio of $\mathrm{N}: \mathrm{P}$ (ammonia nitrogen to phosphate phosphorous) was $25,500 \mathrm{ng} / 1: 73 \mathrm{ng} / 1=350$. For optimum growing of bacteria cultures, this $N: P$ ratio should be $16: 1$; hence, to attain this ratio, about $1.5 \mathrm{mg}$ of phosphorous per liter of solution $(6.8 \mathrm{mg} / 1$ of sodium dihydrogen phosphate monohydrate) must be added to the we 11 water. *

* Note: Due to a calculational error in the nutrient estimations, only

$3.98 \mathrm{mg} / \mathrm{l}$ of $\mathrm{NaH}_{2} \mathrm{PO}_{4} \cdot \mathrm{H}_{2} \mathrm{O}$ was added to the well water in Tests 3 and 4 , rather than the $6.8 \mathrm{mg} / 1$ required to attain the optimum $16: 1$ ratio of $N: P$. 
Table 3-1. Calibration of JRB photometer for amounts of ATP in Hoe Creek II we 11 water samples.

\begin{tabular}{crr} 
Mg of ATP & \multicolumn{2}{c}{ Photometer reading } \\
in 10-m] samp le \\
\hline 0.01 & Assay 1 & Assay 2 \\
0.05 & 5611 & 5747 \\
0.1 & 11161 & 11092 \\
0.5 & 30702 & 25420 \\
& 107027 & 105108
\end{tabular}

a For calibration, $0.2 \mathrm{ml}$ of each of these solutions was added to

$1.0 \mathrm{ml}$ of buffered firefly extract and the degree of biolumineșcence determined,

b Sensitivity, 8.5 .

Table 3-2. Hoe Creek II water samples: ATP analytical results.

\begin{tabular}{cccc}
\hline & \multicolumn{3}{c}{ Photometer reading } \\
\cline { 2 - 4 } Samp le No. & Assay 1 & Assay 2 & Assay 3 \\
\hline 1 & 24172 & 17790 & 17778 \\
2 & 23903 & 23653 & 18332 \\
3 & 22600 & 22050 & 23195 \\
4 & 23285 & 23333 & 23195 \\
& & & \\
Av. & & & \\
\hline
\end{tabular}


Table 3-3. Nutrient analytical results: Hoe Creek II well water.

\begin{tabular}{lccc}
\hline & \multicolumn{3}{c}{ Concentrations $(\mathrm{ppm})$} \\
\cline { 2 - 4 } Species & Sample A & Sample B & Average \\
\hline Phosphate & 0.24 & 0.21 & 0.23 \\
Nitrate & 0.13 & 0.53 & 0.33 \\
Ammonia & 31.0 & 31.0 & 31.0 \\
Nitrite & 0.005 & 0.005 & 0.005 \\
& & & \\
\hline
\end{tabular}

Table 3-4. Calibration of JRB photometer for amounts of ATP present in solution from four bacterial growth tests.

\begin{tabular}{|c|c|c|c|}
\hline \multirow{2}{*}{$\begin{array}{l}\text { Mg of ATP } \\
\text { in 10-ml samp le } \\
\end{array}$} & \multicolumn{3}{|c|}{ Photometer reading } \\
\hline & Assay 1 & Assay 2 & Assay 3 \\
\hline 0.005 & 10896 & 10924 & --- \\
\hline 0.01 & 17481 & 17430 & -- \\
\hline 0.05 & 155939 & 163828 & 159625 \\
\hline
\end{tabular}

a For calibration, $0.2 \mathrm{ml}$ of each of these solutions was added to $1.0 \mathrm{ml}$ of buffered firefly extract, and the degree of bioluminescence was determined.

b Sensitivity, 8.0 . 
As in the previously described Hoe Creek II water analysis, it was necessary to calibrate the JRB photometer to determine the extent of bacterial growth in the four test solutions which had been prepared as indicated in the preceding section. Table 3-4 summarizes the calibration data. Table 3-5 shows the results of the bacterial growth experiments. It can be seen that neither aeration nor an adjusted $N: P$ ratio plus aeration was effective in enhancing bacterial growth. However, significant growth (a factor of 100 increase in bacteria) resulted from addition of yeast to an aerated, N:P adjusted solution.

The effects of bacterial growth on Hoe Creek II water quality parameters are shown in Table 3-6, and Fig. 3-2. As expected, bacterial activity increased the total organic carbon (TOC), biological oxygen demand (BOD), and the chemical oxygen demand (COD) of the water. However, the significant organic contaminants were decreased by a factor of 15 from 7.8 to $0.54 \mathrm{ppm}$ (as determined by gas chromatography--compare Figs. 3-2a and 3-2b).

In conclusion, experiments showed that bacterial growth can be induced in samples of Hoe Creek II well water; such growth has been demonstrated to reduce the concentration of organic chemical pollutants in the water. It is possible that a facility can be designed to biologically purify water that has been contaminated by contact with a UCG project. 
Table 3-5. Bacterial growth experiments: data and results.

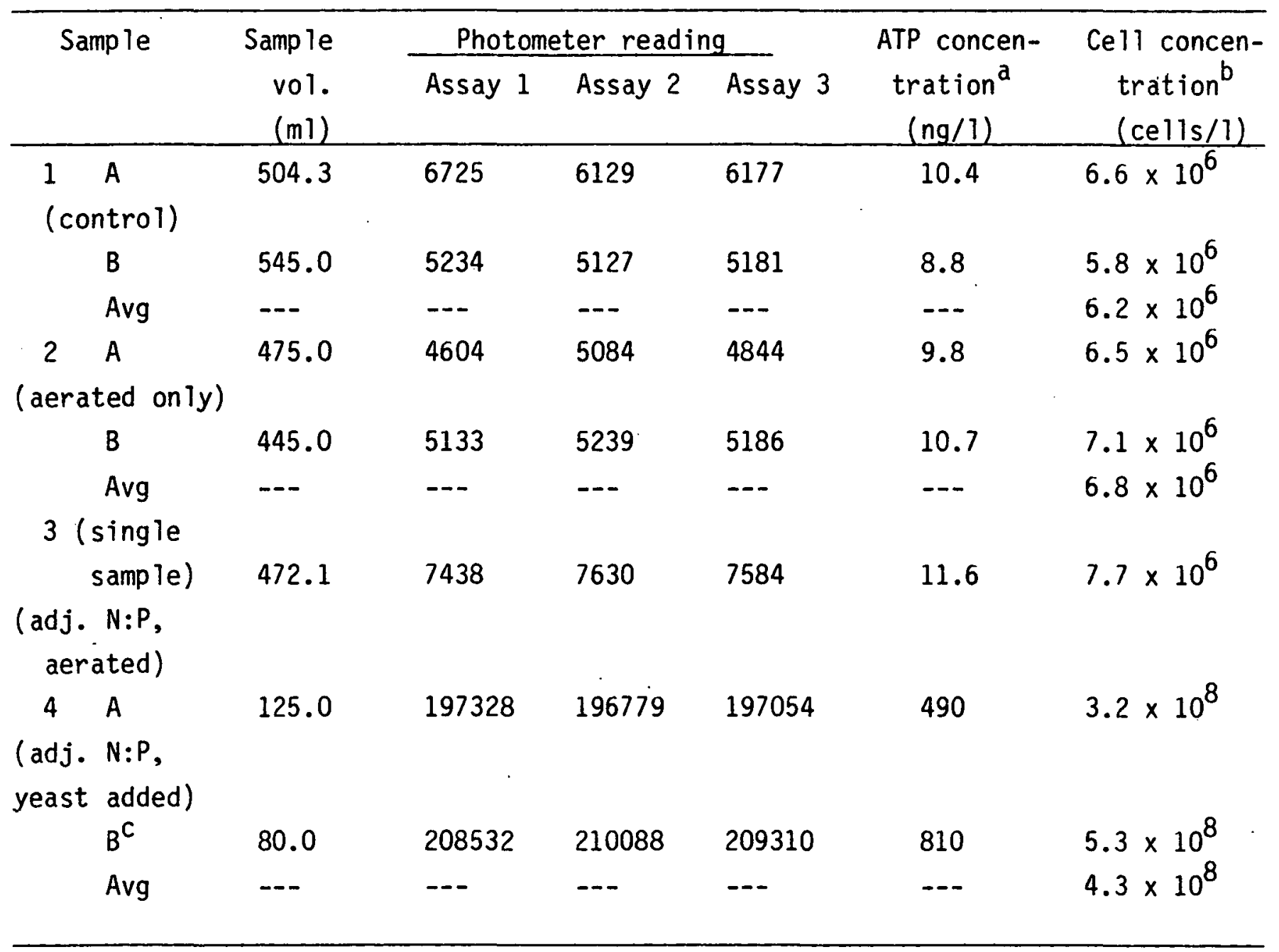

a Calculated using the calibration data in Table 4.

b Calculated using the factor of Holm-Hansen and Booth (1966).

c $8.3 \mathrm{ml}$ of tris buffer used.

Table 3-6. Water quality factors affected by bacterial growth ${ }^{a}$.

\begin{tabular}{lcc}
\hline WQ factor & $\begin{array}{c}\text { Before } \\
\text { treatment } \\
\text { (ppm) }\end{array}$ & $\begin{array}{c}\text { After } \\
\text { treatment } \\
\text { (ppm) }\end{array}$ \\
\hline Total organic carbon & 35 & 450 \\
Biological oxygen demand & 35 & 215 \\
Chemical oxygen demand & 120 & 1000 \\
\hline
\end{tabular}

a $17.4 \mathrm{~g}$ of yeast and $1.38 \mathrm{~g}$ of $\mathrm{NaH}_{2} \mathrm{PO}_{4} \cdot \mathrm{H}_{2} \mathrm{O}$ added to 3.51 of water and aerated in the dark for three weeks. 


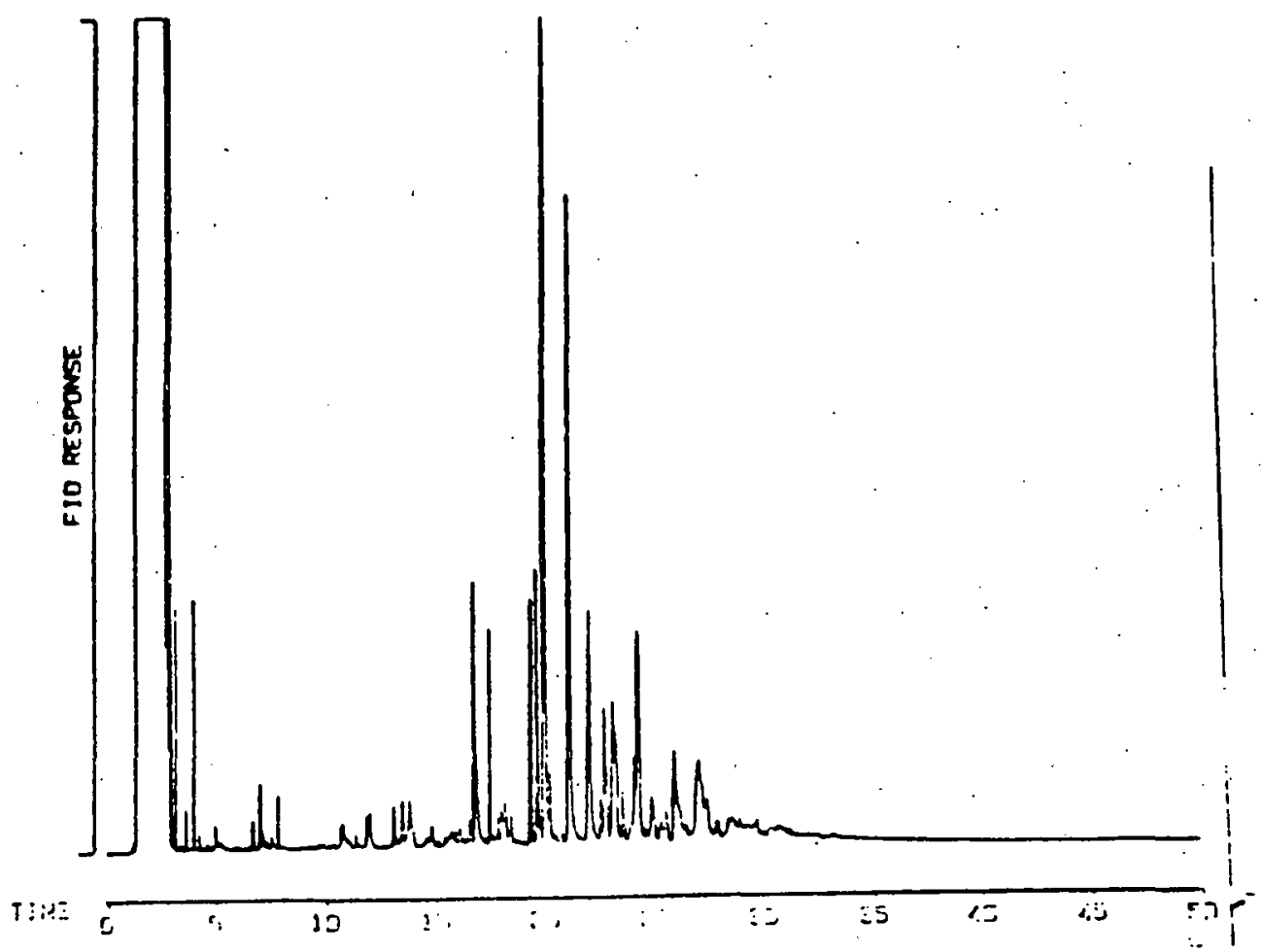

(a)

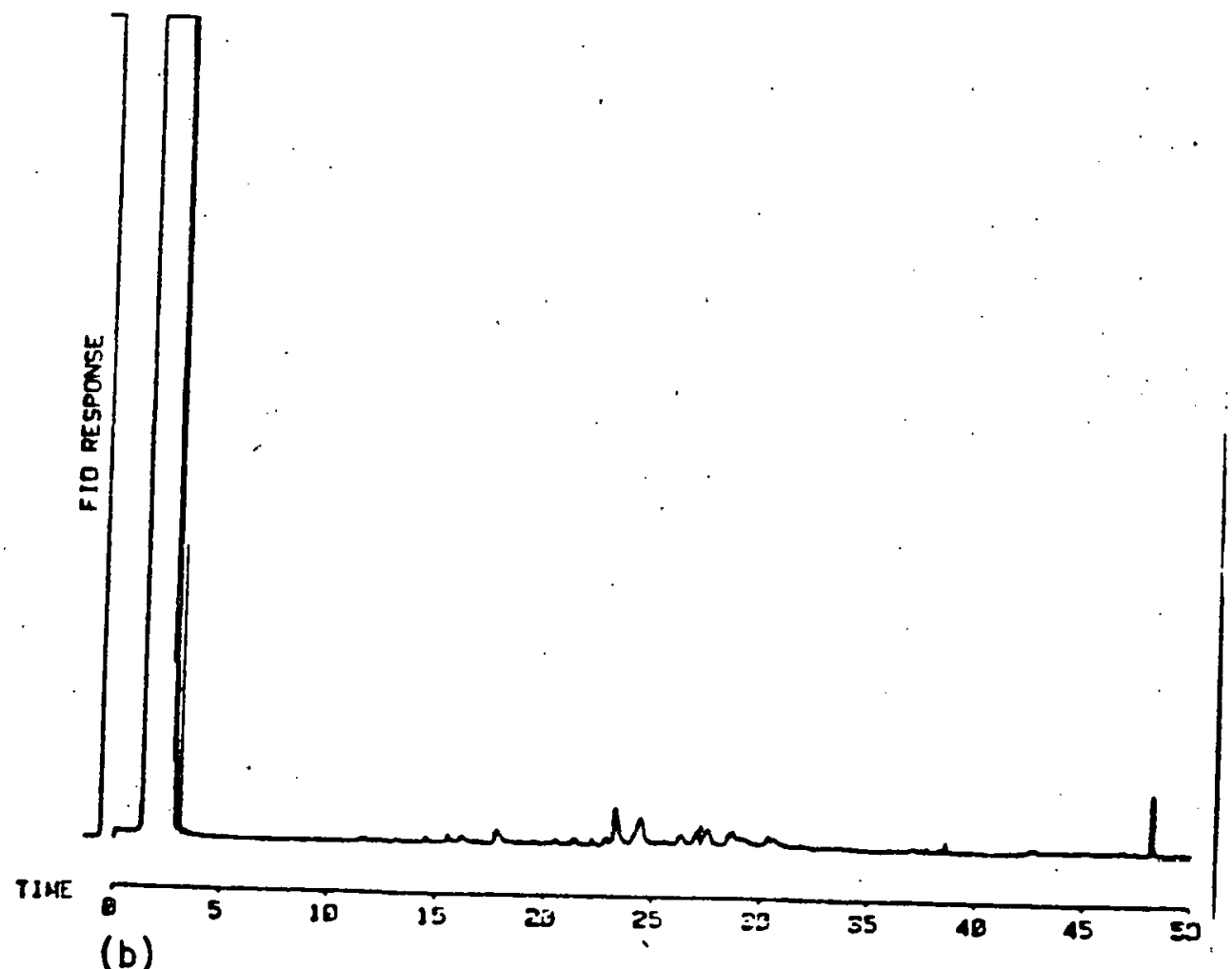

Figure 3-2. Gas chromatograph analytical results: pollutants in Hoe Creek Water.

(a) Before bio-purification.

(b) After bio-purification (factor of 15 reduction in totai concentration of pollutants). 
UCG Water Purification Facility: Conceptual Design and Cost Estimate

Conceptual Design for a Hoe Creek II Treatment Facility

To achieve biostimulation of Hoe Creek II water, an inline mixer would replace the aeration step since the inline mixer dissolves more oxygen and minimizes problems associated with bacterial plugging of the finer parts of the formation. A treatment facility has been designed and its cost estimated. Several assumptions were made before the process was designed:

(1) Water requires no residence time on the surface.

(2) The coal will not chemically reduce the aerated system.

(3) The aquifer will not plug up due to bacterial growth.

(4) There should be enough air to saturate the water.

The water will be pumped from the cavity under pressure through the inline mixer where oxygen will be injected and chemicals added. Polluted water will be pumped out of a centrally located we11, treated, and returned through five injection wells going into the sand, Felix I and Felix II (see Figs. 3-3 and 3-4). By pumping the water out of the UCG cavity a cone of depression is created, in turn allowing the water to flow through the aquifers into the cavity.

The organic contaminants are basically contained within a 20-m radius surrounding the cavity. The five injection wells will be placed 40-m from the cavity center so as to treat all contaminated water. Each of the five wells will go through all three aquifers, where a straddle packer will be used to control the flow, allowing flow to go through only one aquifer at a time. Using the following assumptions, we can estimate the volume of water: 

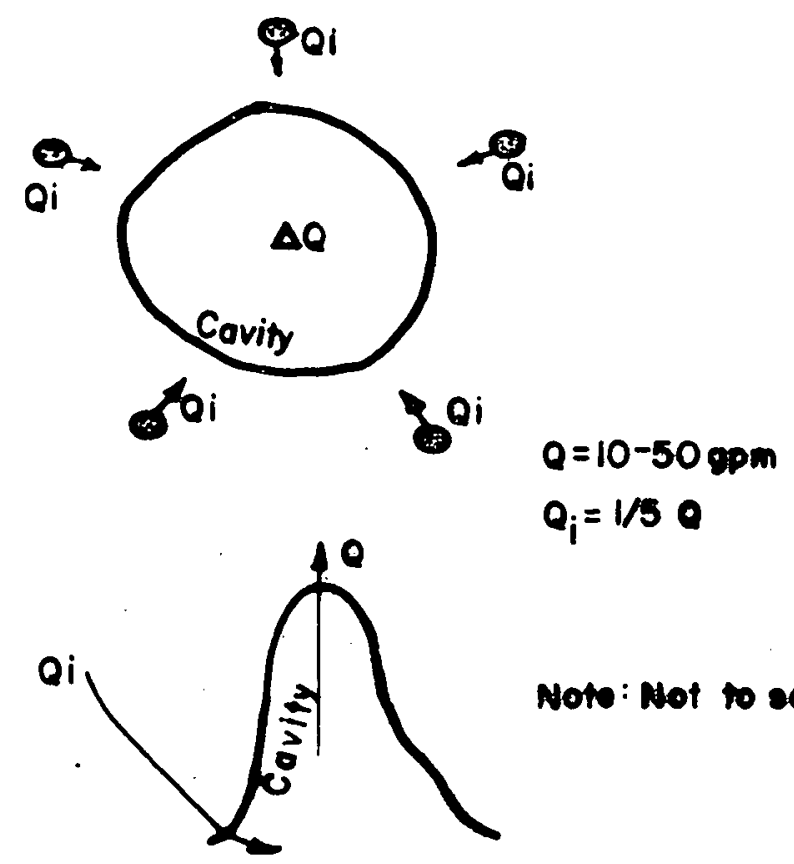

Note: Hot to seele

FIGURE 3-3. Plan view of injection well locations around the Hoe Creek II cavtty.

\section{FLOW PATTERY}

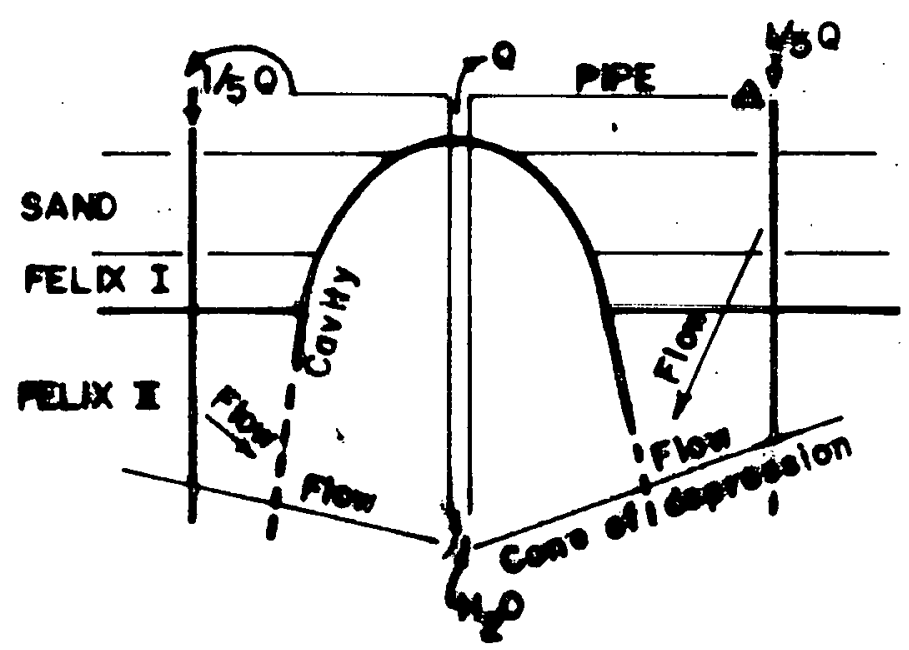

Figure 3-4. Cross section, withdrawal and injection wells, Hoe Creek II. 


$\begin{array}{lll}\text { Porosity }(\theta): & \text { Felix I } & 3 \% \\ & \text { Felix II } & 3 \% \\ & \text { Sand } & 15 \% \\ \text { Thickness: } & \text { Felix I } & 9.84 \mathrm{ft} \\ & \text { Felix II } & 24.93 \mathrm{ft} \\ & \text { Sand } & 24 \mathrm{ft}\end{array}$

Di ameter: $262.4 \mathrm{ft}$

Total volume of water: $\quad 33,500$ gal

Assuming a pumping rate of $50 \mathrm{gal} / \mathrm{min}$, we estimate that this volume of water could be handled in slightly over 11 hours.

COST OF CHEMICALS AND PUMPING:

Sodium Phosphate (phosphate fertilizer-Sim Cal Soil Builders, Helm, CA)

$20 \% \mathrm{P}_{2} \mathrm{O}_{5}: \$ 102.05 /$ ton

Must add $0.003984 \mathrm{~g} / 1$ to $\mathrm{H}_{2} \mathrm{O}$

Cost is $\$ 1.7 \times 10^{-6} / \mathrm{gal}$.

Yeast . (Bacto Yeast-DIFCO Lab., Detroit, MI)

$\$ 464.75 / 10 \mathrm{~kg}$

Must add 5. g/

Cost is $\$ 0.88 / \mathrm{gal}$

Calculations for cost of treating all $\mathrm{H}_{2} \mathrm{O}(33,500 \mathrm{gal})$ with sodium phosphate: $\$ 0.06$

Cost of treating all $\mathrm{H}_{2} \mathrm{O}$ with yeast: $\$ 30,000$.

Cost of pumping all $\mathrm{H}_{2} \mathrm{O}$ (one "turnover" at $0.04 \$ / g a 1$ ): $\$ 13$.

Cost of pumping $\mathrm{H}_{2} \mathrm{O}$ @ $50 \mathrm{gpm}$ for 1 (30-day) month: $\$ 860$.

Assumed Operational Procedure:

Pump for 10 days with air, add nutrients (yeast and sodium phosphate) for one week, then pump for remainder of month. 
TOTAL COST:

Material/Equipment/Operation

Sodium phosphate

Yeast

Pumping o $50 \mathrm{gpm} / 1$ month

Treatment (machines):

Submersible pump

Inline mixer

Small compressure package

3 chemical feeders

Safety valve

Check valve

Electrical control

Drilling Const:

1 well (cased, into cavity)

5 wells adjacent to cavity

TOTAL COST
Cost (\$)

\author{
0.06 \\ 30,000 . \\ 860. \\ 18,000 .
}

$$
\begin{array}{ll}
20,000 . & \text { (est.) } \\
20,000 . & \text { (est.) } \\
\$ 89,000 . & \text { (50-gpm pumping rate) }
\end{array}
$$

This cost is relatively low compared to other forms of cleanup. 


\section{BIBLIOGRAPHY}

Cavari B., 1976, "ATP in Lake Kinnaret: Indicator of Microbial Biomass or of Phosphorous Deficiency?," Limnol. Oceanogr. 21, (2), 231-236.

Holm-Hansen, 0. and Booth, C.R., 1966, "Measurement of Adenosine Triphosphate in the Ocean and its Ecological Significance," Limnol. Oceanogr. 11, (4), 510-519.

Kar 1, D.M. and Larock, P., 1975, "Adenosine Triphosphate Measurements in So 1$]$ and Marine Sediments," J. Fish. Res. Board Can. 32, 599-607.

Riemann, Bo, 1979, "The Occurrence and Ecological Importance of Dissolved ATP in Fresh Water," Freshwater Biol. 9 (5), 481-490.

Suntech, Inc., 1981, Interim Status Report, Heleva Landfill Bioreclamation Project, Suntech, Inc., P.0. Box 1135, Marcus Hook, PA 19061. 
REPORT 4 -- Howard J. Turner, III

HAZARDOUS WASTE LITERATURE REVIEW

This brief technical note is a review of current information concerning hazardous waste disposal. The area of waste disposal encompasses the effective isolation from the biosphere of a variety of discarded materials that could prove hazardous under certain conditions. However, this report will concentrate specifically on toxic hazardous wastes.

Hazardous wastes pose research and regulatory problems for the Environmental Protection Agency (EPA) and operational problems for industry. The Resource Conservation and Recovery Act (RCRA) requires the EPA to establish standards and procedures for control of waste generators. This report reviews available information concerning hazardous waste. disposal technology and EPA regulations; it points out areas where definitive solutions are lacking.

\section{CHARACTERISTICS OF HAZARDOUS WASTE}

There are two ways by which a waste material is classified as hazardous; either by its presence on the EPA-developed listing of hazardous wastes, or by exhibiting particular ignitable, corrosive, reactive, or toxic characteristics. The EPA list of hazardous waste materials includes both spent halogenated and nonhalogenated solvents. Also included are wastes from electroplating baths and waste water treatment sludges from many production processes. Some commercial chemical products are also considered to be hazardous waste when discarded. These include such substances as arsenic, acids, cyanides, and many pesticides; and toxic wastes such as 
benzène, toluene, urethane, and phenols. Soluble salts of suich métàls as zinc; copper, lead, chromium, cadmium, and nickel are termed hazardous when present in significant quantities.

A solid waste is considered hazardous if it exhibits any of the following characteristics:

1. Ignitability

a. A liquid with a flash point less than $140^{\circ} \mathrm{F}\left(60^{\circ} \ddot{\mathrm{C}}\right)$.

b. A nonliquid capable of causing fire through friction; absorption of moisture, or spontaneous chemicàl changes, thät whén ighnitêd burns so vigorousiy and persistently that it c̈reates a fiàzàrd.

c. An ignitable compressed gas or oxidizer (see DOT transportation regulations; 49 Code of Federal Regulations $\mathbf{1} 7 \overline{3} . \overline{3} 0$ or $173 . \overline{1} \bar{j} \dot{1})$ :

\section{Corrosivity}

a. An aqueous liquid that has a pH less than or eqquã to 2.0; or greater than or equal to 12.5 .

b. A liquid that corrodes steel at a rate greater than $i / 4 \mathrm{in} / \mathrm{yr}$.

\section{Réactivity}

a. The waste is normally unstable and readily undergoes violènt change without detonating.

b. It reacts violently with water.

c. It forms potentially explosive mixtures with water.

d. When mixed with water, it generates toxic gases, vapors, or fumes in a quantity sufficient to present a danger to human health or the environment.

e. A cyanide- or sulfide-bearing waste that, when eẍpösed to $\mathrm{pH}$ conditions between 2 and 12.5, can generate toxic gases, vapors or fumes in a quantity sufficiènt to present a dàngêr tô humañ heaith or the environment: 
f. A waste capable of detonation or explosive reaction if it is subjected to a strong initiating source or heated under conf inement.

g. Material readity capable of detonation or explosive decomposition or reaction at standard temperature and pressure.

h. An explosive, forbidden explosive, or Class B explosive as defined in DOT transportation regulations (49 CFR 173.51, 173.53 or 173.88)

\section{Toxicity}

A waste material, the extract* of which contains any of the below contaminants at concentrations equal to or greater than the values indicated:

Maximum

Contaminant

Concentration $(\mathrm{ppm})$

Arsenic

5.0

Barium

100.0

Cadmium

1.0

Chromium

5.0

Lead

5.0

Mercury

0.2

Selenium

1.0

Silver

5.0

Endrin

0.02

Lindane

0.4

Mexthoxychlor

10.0

Toxaphene $\left(\mathrm{C}_{10} \mathrm{H}_{10} \mathrm{Cl}_{8}\right.$, technical)

(chlorinated camphene, 67-69\% chlorine) 0.5

2,4-D (2.4-dichlorphenoxyacetic acid) $\quad 10.0$

Silvex 2 (2,4,5-trichlorophenoxypropionic acid) 1.0

* The extract consists of the liquid component of a solid waste and deionized water at $\mathrm{pH} 5.0$, which has been continuously brought into contact with the solid phase of the waste for a 24-hour period. 


\section{PRESENT PACKAGING METHODS FOR DISPOSAL}

According to EPA standards, stabilization and solidification are proper methods to dispose of waste. These methods allow the surface area of the waste to be reduced, lowering the permeability of the resultant solid and preventing rapid leaching of the toxic material.

The materials regularly used to encapsulate the waste material include:

epoxy resins

polymeric sulfur

asphalt

plastic binders polyethylene

polypropylene

urea formaldehyde

vinyl polyester

\section{CURRENT DISPOSAL METHODS}

Land Disposal is the most frequently used method of hazardous waste disposal. Technology weaknesses lie in controlling the migration of leachates from sites into the surrounding environment, and in the residual build-up of chemicals within the soils in the vicinity of the pollutant sources.

Because landfills are used extensively for waste disposal, the EPA has established specific criteria for Class I waste site design. Complete protection to maintain the quality of groundwater must be provided. Geological conditions must be such as to prevent vertical and lateral hydraulic continuity between liquids and gases--associated with the wastes at the site--and usable surface and groundwaters. The disposal area can be modified to prevent any lateral hydraulic continuity, and should not overlie usable groundwater except under exceptional circumstances. The permeability from the disposal area must not exceed $10 \times 10^{-8} \mathrm{~cm} / \mathrm{sec}$. The specified soils include silty clay $(\mathrm{CL})$, adobe clay $(\mathrm{CH})$ or organic clay $(\mathrm{OH})$ with not less than $30 \%$ passing through a number 200 sieve, with the liquid limit and plasticity index set at 30\% each. 
Deep-Well Injection can be a safe method of disposal for all types of hazardous wastes if the disposal site is properly located, designed, operated, managed, and regulated. Weaknesses exist in areas of chemistry, microbiology, engineering, and geology. Tentatively excluded as being safe for deep-well injection are 13 chemicals and their related compounds. These chemicals include:

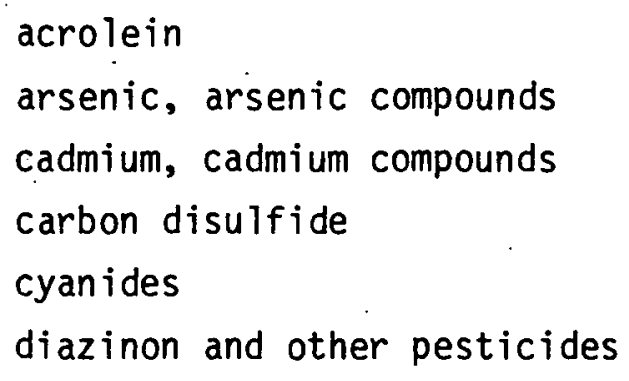

\section{fluorides}

hydrocyanic acid hydrofluoric acid hexavalent chromium compounds mercury, mercury compounds nitrophenol

Land Cultivation is an optional disposal method for pharmaceutical, tannery, food processing, paper and pulp, and oil refinery industries. The principal weakness lies in the danger of groundwater contamination.

Underground Mines are a feasible method of storage for hazardous wastes. However, there is a considerable lack of experience in the proper packaging of waste to prevent leakage into the environment.

Ponds and Lagoons are extensively used for on-site disposal and storage. Concern involves migration of waste into soils and aquifers. Incineration is used frequently for reduction of wastes into an ash or residue. However, it is not effective in destruction of organic waste seriously contaminated with volatile components (e.g., mercury, selenium, thallium, arsenic, etc.). It appears that incineration will be limited to organic materials for which land treatment is not applicable. 


\section{DISPOSAL REGULATIONS}

In 1976 the Resource Conservation and Recovery Act was passed; the law will: have a dramatic effect on the methods of hazardous waste disposal. As a result of technical advances and regulations, industries generating: hazardous wastes over the next decade will encounter numerous issues regarding the selection and implementation of approved methods for hazardous waste management.

Currently, land-based disposal is used for most hazardous wastes. However, land-based disposal sites will be required to attain more efficient: containment of waste materials, and to demonstrate improvements in the areas of emission control.

\section{EPA RESEARCH GOALS}

EPA's primary concern is with the migration of hazardous waste leachates from land-fills, wells, and other disposal facilities into soils and shalliow aquifers. Another area of concern is the residual chemical build-upi in soils in the vicinity of pollutant sources. Listed below is an assessment of EPA goals and needs in waste technology and in the identification of hazardous wastes.

Significant goals include evaluating current waste disposal site sampling and analytical procedures, as well as developing monitoring guidelines and a quality assurance program. The EPA also plans to identify, to sample, and to characterize current industrial hazardous: wastes and water streams and to assess current methods of disposal:

Under the area of waste technology, the needs are categorized: as short-term, medium-term, and long-term.

\section{Short-Term Needs:}

1. To develop a data base and guidance manual for evaluation of proposed land-fijlls', surface impoundments, and l'and treatment fäctilities: 
2. To develop protocols for evaluating hazardous waste fixation and encapsulation methods

3. To develop methods for prediction of volatile emissions from surface impoundments and land disposal facilities

4. To develop, evaluate, and validate measurement methods to determine the destruction efficiency of incineration facilities

Medium-Term Needs:

1. To determine the compatibility of industrial hazardous wastes with various disposal technologies

2. To develop and to demonstrate cost-effective technologies for the treatment, detoxification, or destruction of industrial hazardous wastes

3. To determine the potential for recycling or reuse of industrial wastes

4. To determine the potential for regional hazardous waste management facilities

Long-Term Needs:

1. To develop data on options to improve land disposal site design and management for treated wastes

2. To develop and to demonstrate alternatives to land-fill disposal

3. To determine methods to increase recovery and use of secondary materials REMEDIAL ACTIONS

There are no conventional methods for clean-up of hazardous materials. There is a definite lack of technology for remedial actions. Several methods have been investigated at the laboratory level. However, none have proven to be successful in resolving the problems associated with leaching, migrating toxics, or improperly buried waste. These methods include sludge composting, soil attenuation, site encapsulation, and the treatment of waste with oxygen and uitraviolet light. 
Recently, LLNL has been involved in evaluating some unconventional in-situ methods to control and mitigate groundwater contamination problems. These include injection of ozone, oxygen, or waste-consuming bacteria. In addition, state-of-the-art monitoring and sampling techniques can be made available from individuals who participated in the University of Waterloo Short course, "Field Methods in Contaminated Hydrology," April 1981. 
BIBL IOGRAPHY

Berkowitz, Ivan B., 1977, Physical, Chemical, and Biological Treatment

Techniques for Industrial Wastes, Volume I, Little (Arthur D.), Inc.

Cambridge, MA. Environmental Protection Agency, Washington, D. C.

Carme1, Matthew M., and Garrison, Richard P., 1981, "An Approach to RCRA

Hazardous Waste Management," Am. Ind. Hyg. Assoc. J. 42, 515-520.

Cleary, Robert W., Miller, David W., and Pinder, George F., 1980, Groundwater

Pollution and Hydrology (short course), GRC Services, Princeton, NJ .

Dallaire, Gene, "Hazardous Waste Management in California: Lessons for the

U.S.," Civil Engineering - ASCE, April 1981, pp. 53-56.

EPA, 1981, "Environmental Protection Agency Regulations for Identifying

Hazardous Wastes", U.S. Code of Federal Regulation (40CFR261).

Ghassemi, M., 1976, Analysis of a Land Disposal Damage Incident Involving

Hazardous Waste Materials. TRW Systems Group, Redondo Beach, CA, Environmental Protection Agency, Washington, D. C.

Gibb, J. P., "Field Verification of Hazardous Waste Migration from Land

Disposal Sites," in Land Disposal of Hazardous Wastes: Proceedings of

the Fourth Annual Research Symposium, San Antonio, TX, March 6-8, 1978,

pp. 215-232, Environmental Protection Agency report EPA-600/9-78-016.

Gradat, A., and Short, W. L., 1980, "Managing Hazardous Wastes under

RCRA-Part II," Chem. Eng., 87 (15), 60-68.

Lynch, John W., 1980, "The New Hazardous-Waste Regulation--Part I," Chem.

Eng., 87 (15), 55-59.

Pojasek, Robert B., 1978, "Stabilization, Solidification of Hazardous

Wastes," Environ. Sci. Technol., 12, 382-386.

Pojașek, Robert B., 1979, "Dịsposing of Hazardous Chemical Wastes,"

Environ. Sci.Technol., 13, 810-814. 
Schomaker, Norbert B., "Current Research on Land Disposal of Hazardous Wastes," in Land Disposal of Hazardous Wastes: Proceedings of the Fourth Annual Research Symposium, San Antonio, TX, March 6-8, 1978, pp. 1-13, Environmental Protection Agency report EPA-600/9-78-016.

University of Waterloo, "Field Methods in Containment Hydrogeology," (short course), The Hydrogeology Group, University of Water 100, Water 100, Ontario, Canada (1981).

Wiles, Carlton C., "Assessment of Deep Well Injection of Hazardous Waste," in Land Disposal of Hazardous Wastes: Proceedings of the Fourth Annual Research Symposium, San Antonio, TX, March 6-8, 1978, pp. 397-404, Environmental Protection Agency report EPA-600/9-78-016. 
REPORT 5 -- Debra A. Tatman

PART I. SEISMIC NOISE IN THE USSR

PART II. CORRELATION OF SEISMIC SIGNAL WITH EXPLOSION YIELD

PART III. GROUND MOTION RECORDED IN VICINITY OF UNDERGROUND

COAL GASIFICATION EXPERIMENT

\section{INTRODUCTION}

This report summarizes my work at LLNL this surmer. I have been involved in three projects: (1) In support of the Seismic Verification Program (SVP), I surveyed seismic noise (background) levels in the USSR under the guidance of Peter Rodgers of the Applied Geophysics Group. My second task involved the correlation of seismic P-wave amplitude with explosion yield. Jean Younker (Geology Group Leader) was my project director for this work, which was also carried out in support of the SVP. (3) I reduced and analyzed ground deflection data obtained from the Hoe Creek III experiment of the Underground Coal Gasification (UCG) Project. For this latter task, I worked with Abelardo Ramirez of the Engineering Geology Group, K Division.

\section{VERIFICATION PROJECT (COMPREHENSIVE TEST BAN TREATY)}

The first project involved the Comprehensive Test Ban Treaty work going on at LLNL. My task was to indicate seismic noise levels in the Soviet Union on a tectonic map of the USSR (Proskurjakova et al, 1973). This was done so that areas of the lowest seismic noise could be found where seismic stations could be sited if a seismic monitoring system is allowed within the Soviet Union (Nordyke, 1981). A small-scale version of the resulting map is shown in Fig. 5-1. The different levels of background noise are indicated. The greatest interest is in the areas having the lowest background noise. The areas shown to have the highest background noise occur in eastern Siberia. The other areas are characterized by mild seismic noise levels. 


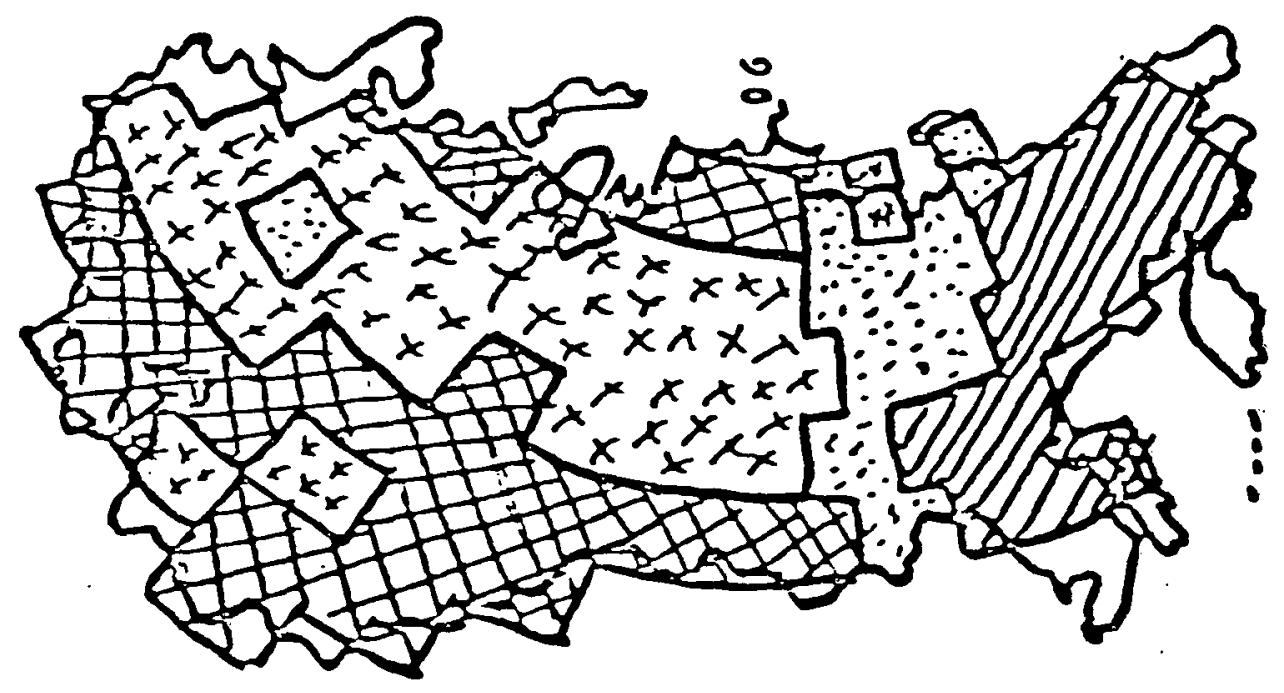

1-sec noise, nim

$\$$ Very low: $n m \leq 1$

Low: $n m \quad 1<n m \leq 10$ $[\because \vdots 9$ Medium: $10<\mathrm{nm}<100$

DHigh: $\mathrm{nm} \geq 100$

Figure 5-1. Seismic noise levels of the Soviet Union.

(average vertical peak-to-peak amplitude of the seismic noise in nm.) 


\section{NEVADA TEST SITE EVENT ANALYSIS (SEISMIC VERIFICATION PROJECT)}

This study was carried out to understand better the relationship between the yield of an underground explosion and the size of the seismic wave produced by the explosion (Dahlman and Israelson, 1977). A unique set of regional seismic data with known events (11 NTS events) was used to better understand what information could be generated from having a seismic monitoring system in the Soviet Union (Nordyke, 1981). The names and dates of the 11 events are given in Table 5-1; the locations are shown in Fig. 5-2. These events, which were recorded on the LLNL four-station seismic network, were run through two calculations (linear regressions and correlation coefficients) on a hand calculator to determine if there was a linear relationship between the log of the $P$-wave amplitude and the explosive yield. These shot data were then plotted, and the preliminary results can be seen in Fig. 5-3. Therefore, if there is a supposed nuclear explosion in Russia and the $P$-wave amplitude is determined, one would then be able to calculate the approximate size of the explosion provided that the area has been appropriately calibrated.

Table 5-1. Dates and names of nuclear explosions used in this study. Numbers (1-11) refer to the code used for approximate locations for the 11 events plotted on the map in Fig. 5-2.

\begin{tabular}{lll}
\hline 1 & $9-6-79$ & Hearts \\
2 & $8-3-79$ & Burzet \\
3 & $8-8-79$ & Offshore \\
4 & $4-16-80$ & Pyramid \\
5 & $4-3-80$ & Liptauer \\
6 & $8-29-79$ & Nessel \\
7 & $2-28-80$ & Tarko \\
8 & $11-29-79$ & Backgammon \\
9 & $3-8-80$ & Norbo \\
10 & $9-8-79$ & Pera \\
& $11-12-14-79$ & Azul \\
\hline
\end{tabular}




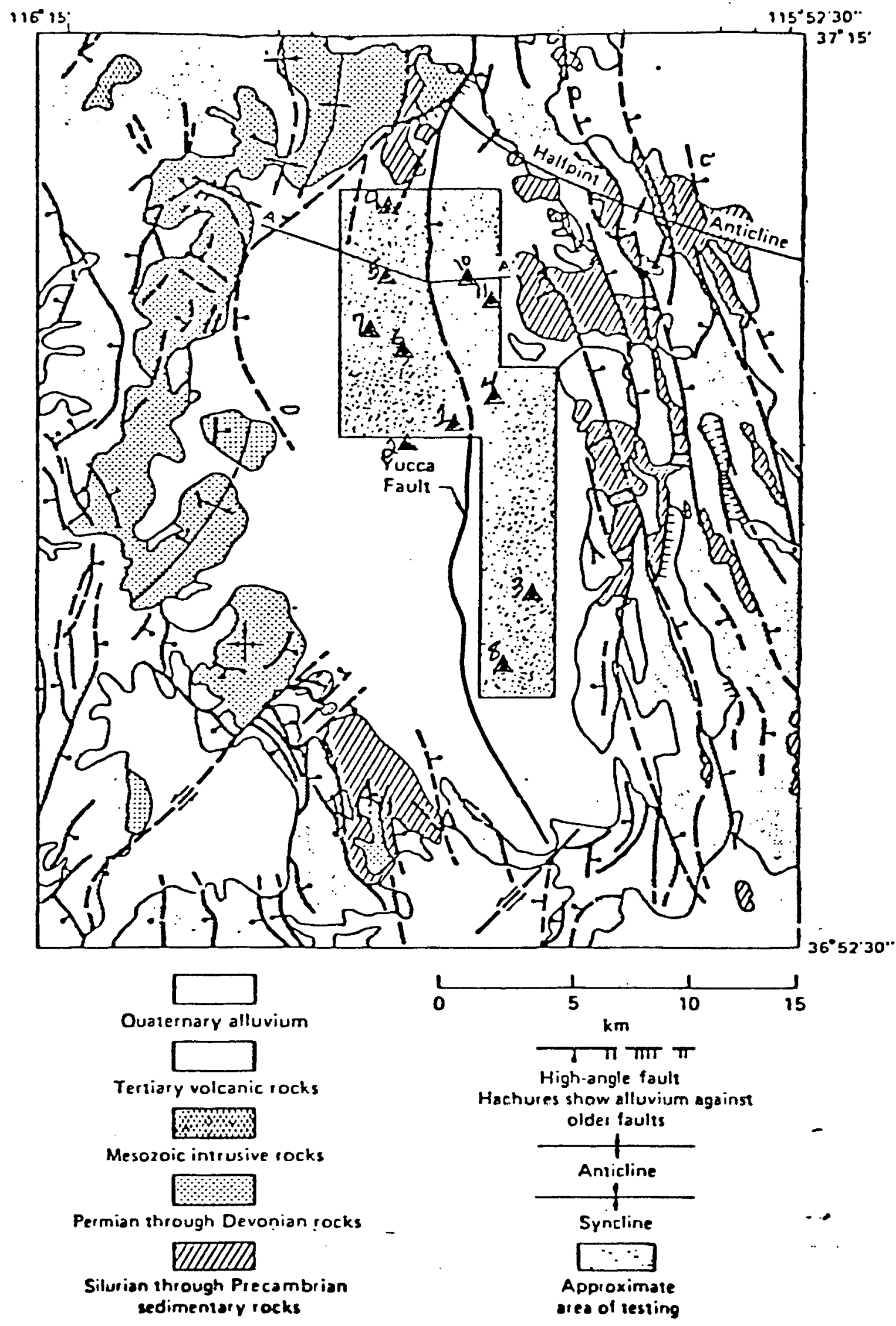

Figure 5-1. Location of nuclear explosions listed in Table 5-1. 


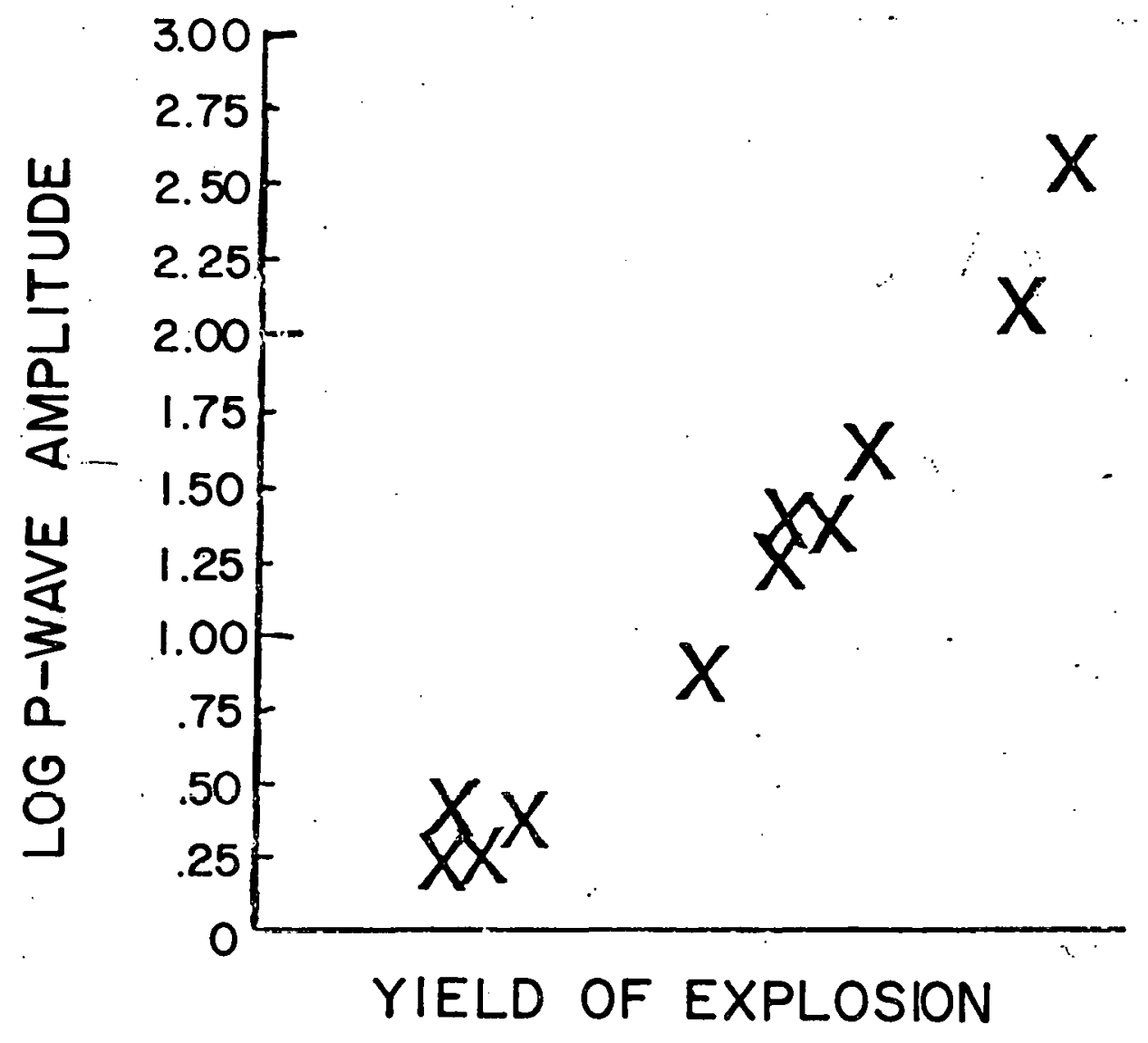

Figure 5-3. Graph of log-linearity between $P$-wave amplitude and yield of explosion. 
The overall goal of the Underground Coal Gasification (UCG) Project is to develop a method for the in situ conversion of coal into combustible gases by subsurface burning of the coal. This is done by the heating of coal in the presence of gasifying agents such as oxygen and steam ( $\mathrm{Hi} 11$, 1980). Two important environmental concerns associated with in situ coal gasification are groundwater contamination and post-burn subsidence of the overburden.

I worked on the subsidence aspect of the coal program this summer. Six instrumentation boreholes were drilled around the injection wells at the Hoe Creek III site as shown in Fig. 5-4.

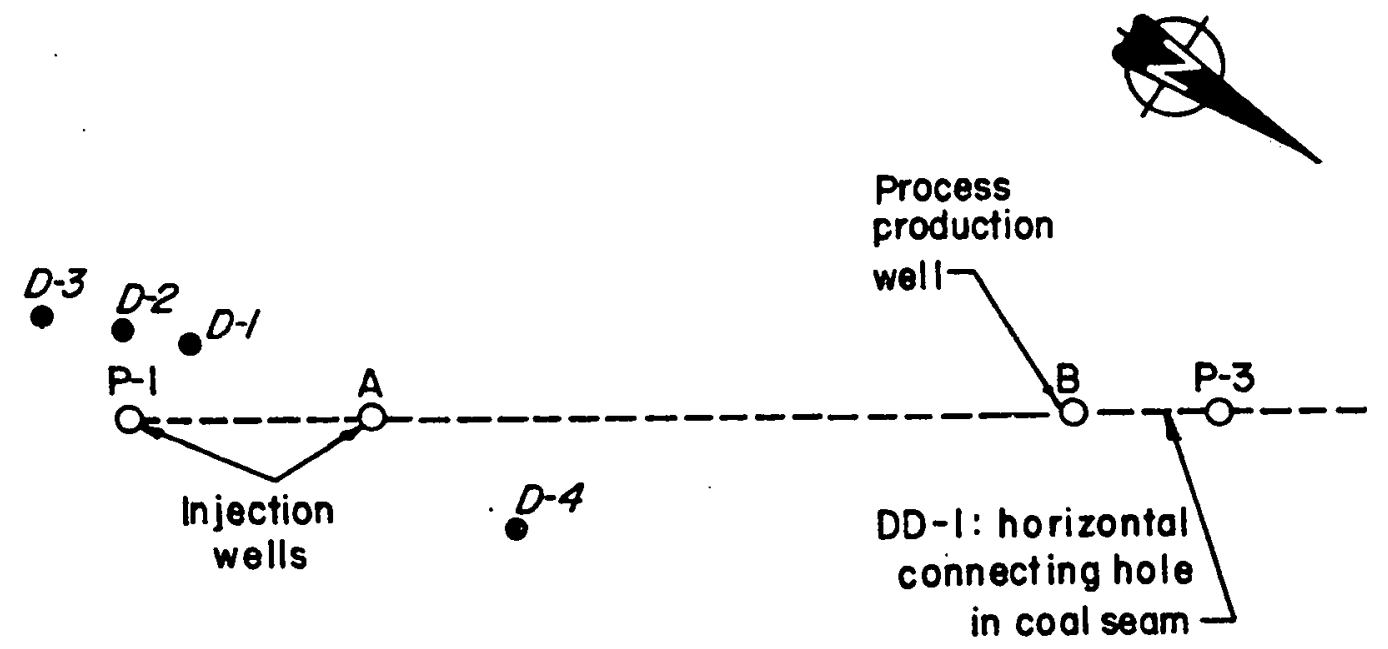

0.5

$\cdot D-6$

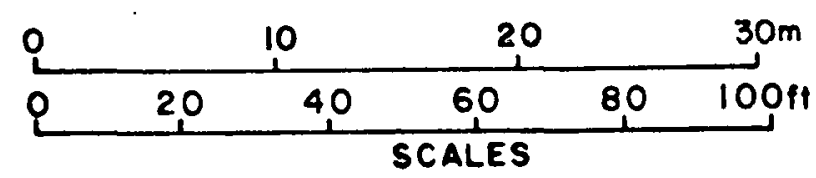

Figure 5-4 Location of six instrumentation boreholes in relation to injection wells for Hoe Creek III experiment near Gillette, WY. 
Deflectometers were periodically lowered into the six boreholes to measure how much the borehole casings were deflected during and after a burn (Ganow, 1978). The deflectometers were designed to detect and record horizontal movement of the borehole casings in two directions by means of sensors oriented at right angles to each other. The respective signals from the two sensors were fed into two channels (designated $A$ and $B$ ) of a recorder. The sensor orientations (as represented by their channel designations) are shown in Fig. 5-4; the deflectometer boreholes are labeled D-1 through D-6, respectively. Figures 5-5 through 5-8 show horizontal deflections calculated using several computer programs which reduced and corrected the raw deflectometer data. The ground displacement increased with time. Fig. 5-9 presents two vertical profiles that show the increased deflection with time elaspsed since the beginning of the burn. The top drawing shows horizontal motion perpendicular to the burn, while the lower drawing shows horizontal motion parallel to the burn. (Note that in the Figs. 5-5 through 5-9, Channel A records the horizontal motion perpendicular to the burn, while the horizontal motion parallel to the burn is shown in Channel B.) In addition, plots showing orientation of vector motion (shown in Figs. 5-10 through 5-13) were also generated. 
HOE CREEK II I DEFLECTIONS

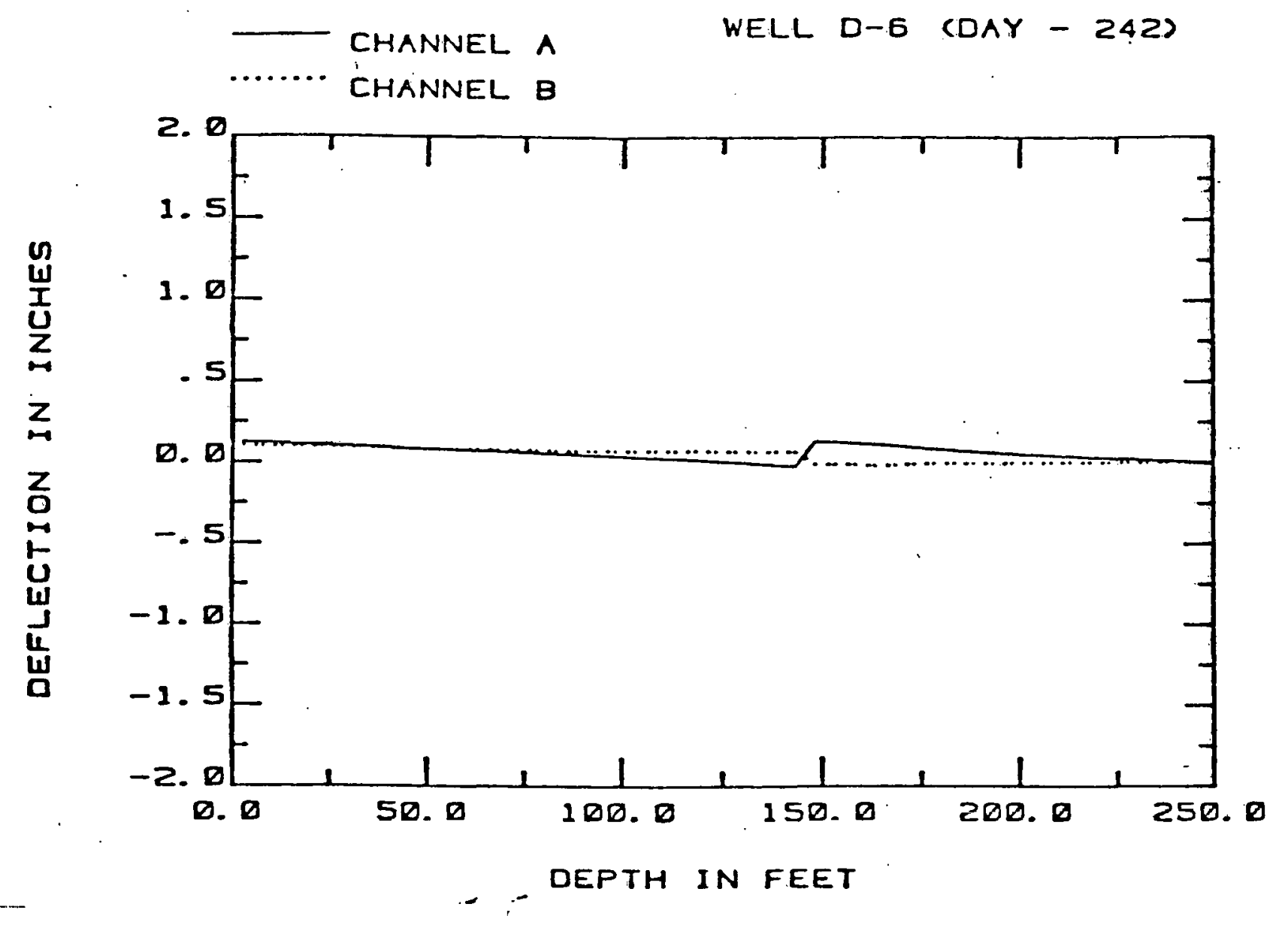

Figure 5-5. Deflections occurring 12 days after beginning of coal burn. 


\section{HOE CREEK I I I DEFLECTIONS}

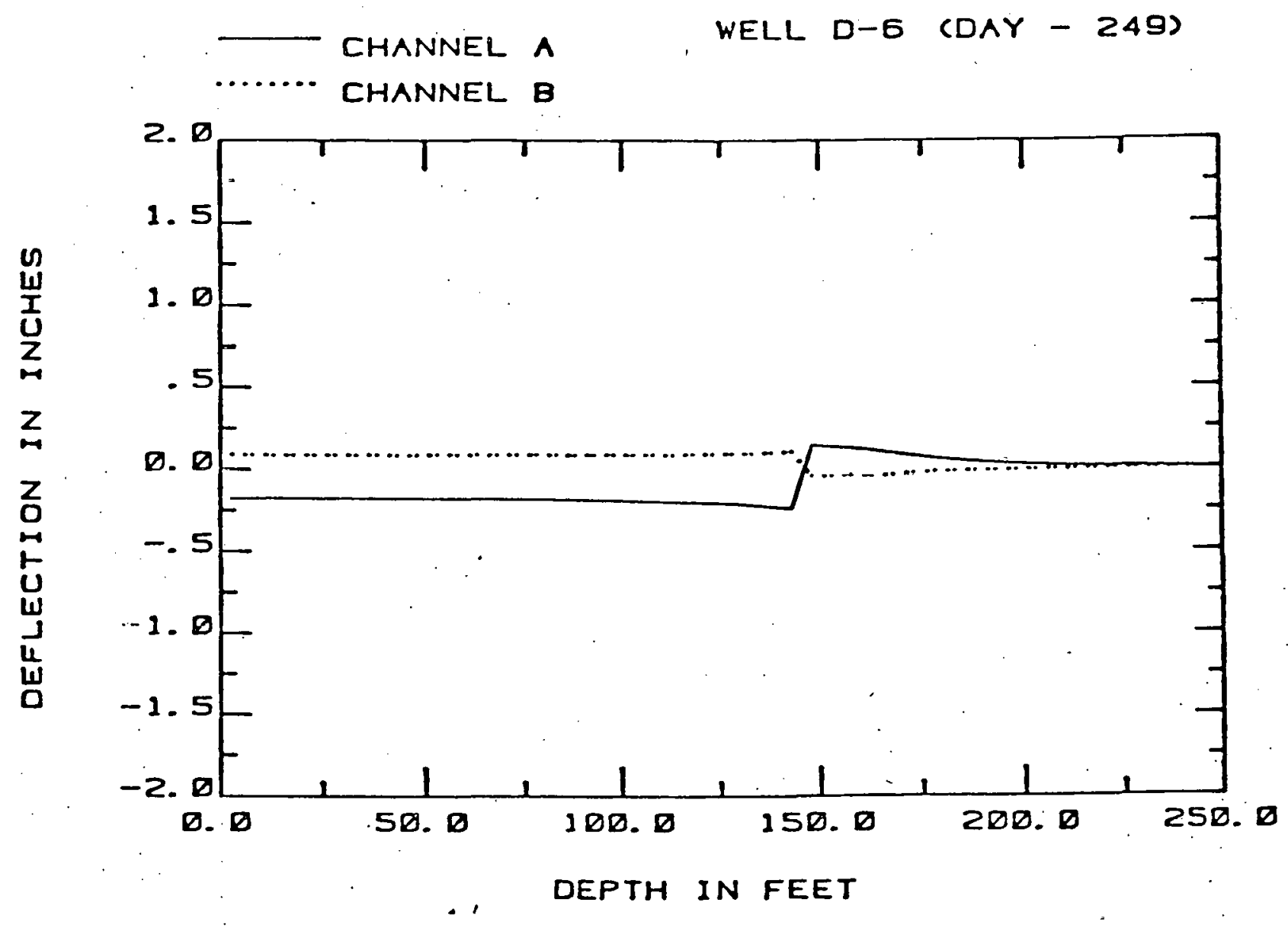

Figure 5-6. Deflections occurring 19 days after beginning of coal burn. 
HOE CREEK I I I DEFLECTIONS

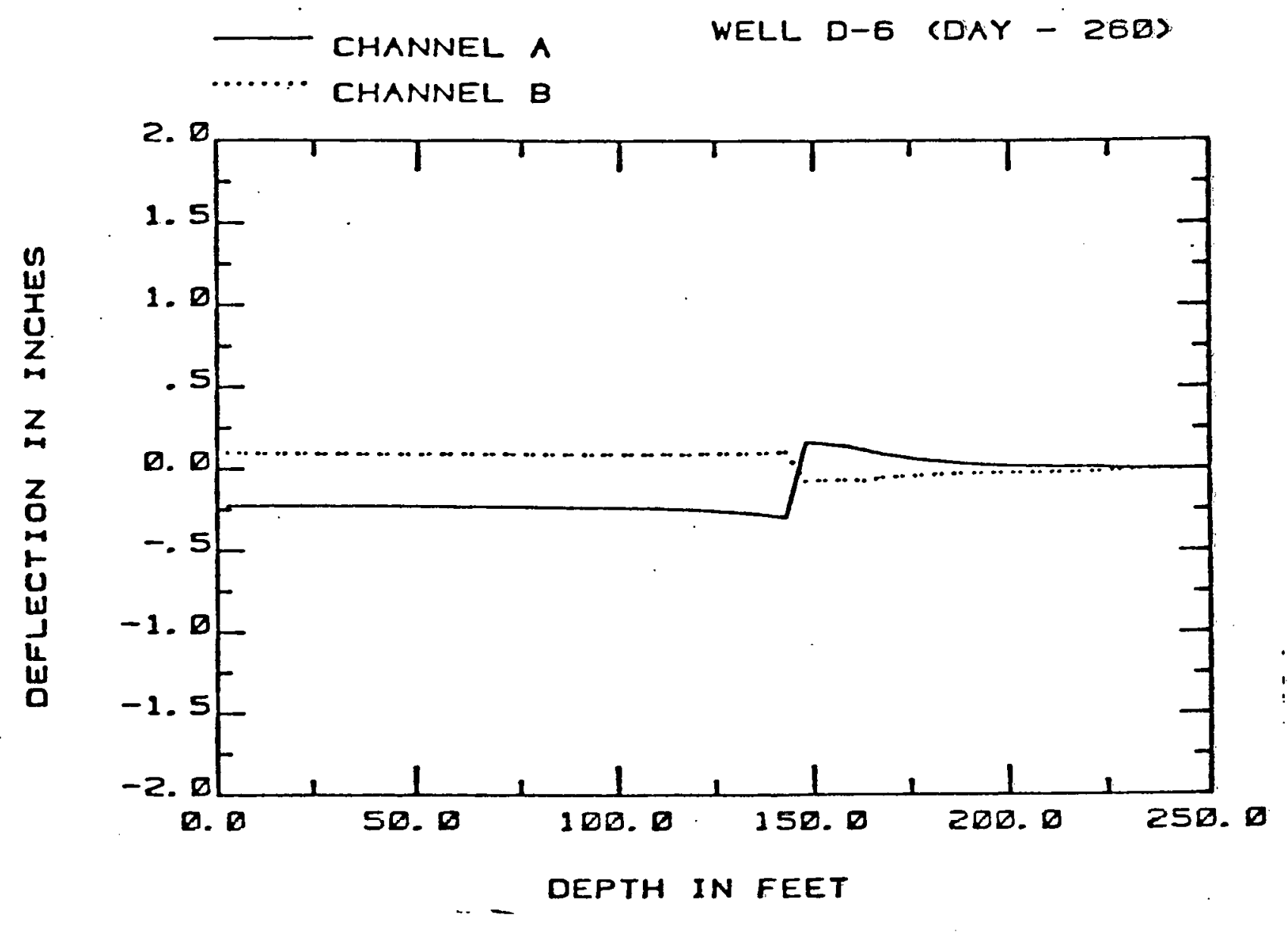

Figure 5-7. Deflections occurring 30 days after beginning of coal burn. 
HOE CREEK I I I DEFLECTIONS

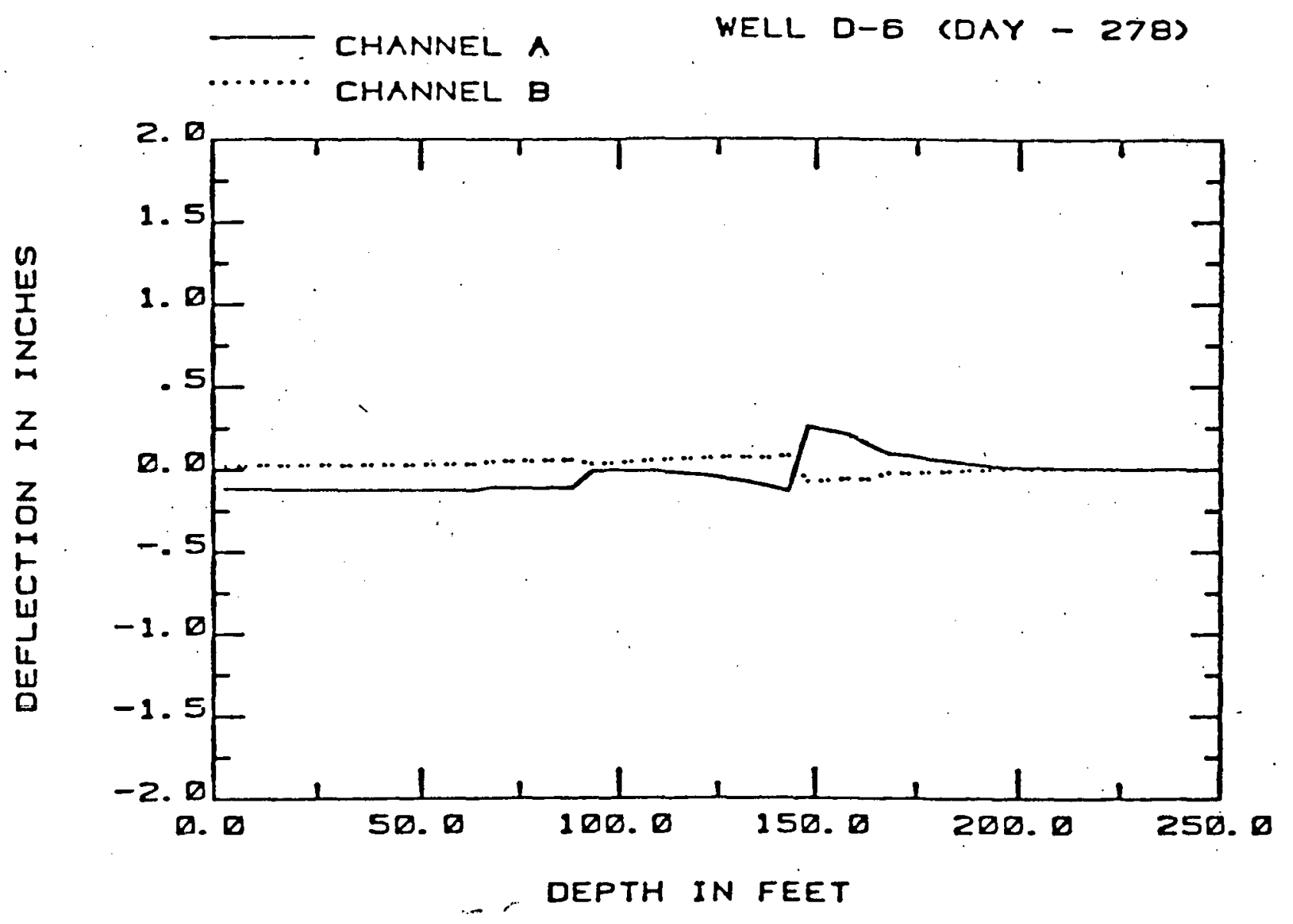

Figure 5-8. Deflections occurring 48 days after beginning of coal burn. 


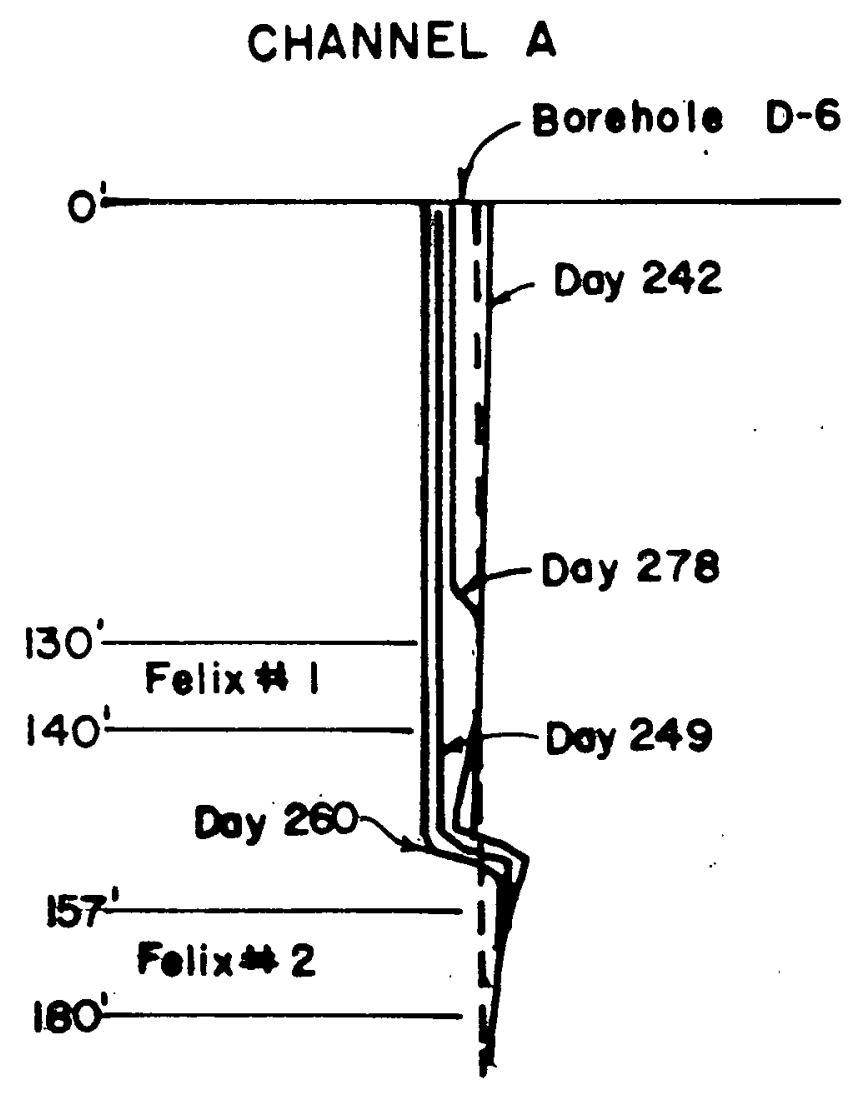

CHANNEL B

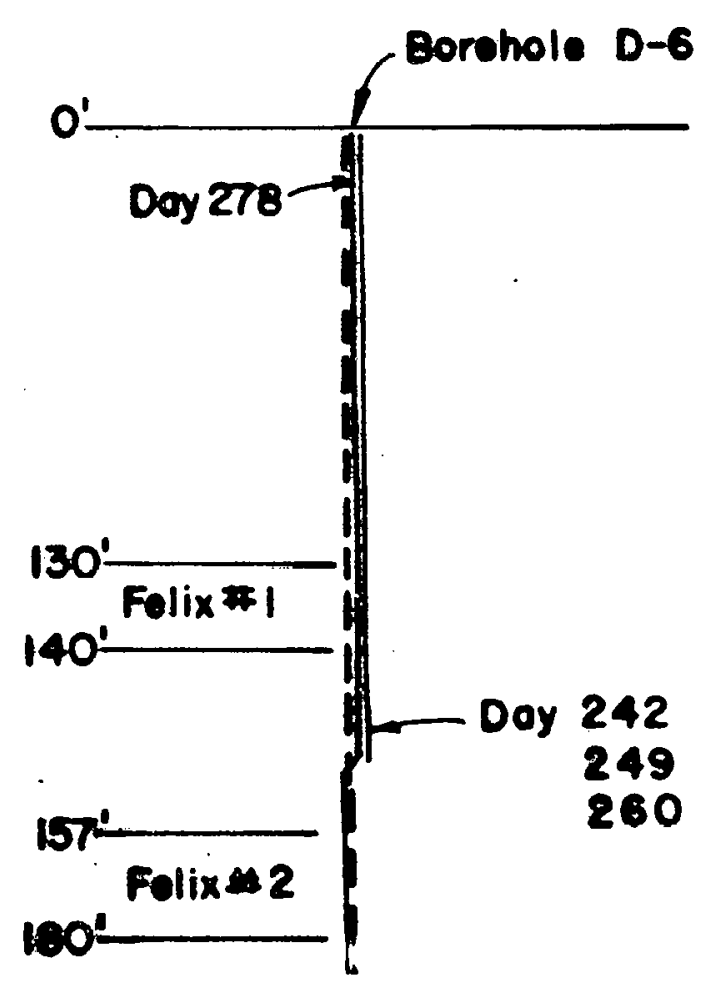

Figure 5-9. Schematic drawings of borehole and motions in relation to Felix \#1 and Felix \#2 coal beds. 
PREDOMINANT DEFLECTION PLANES

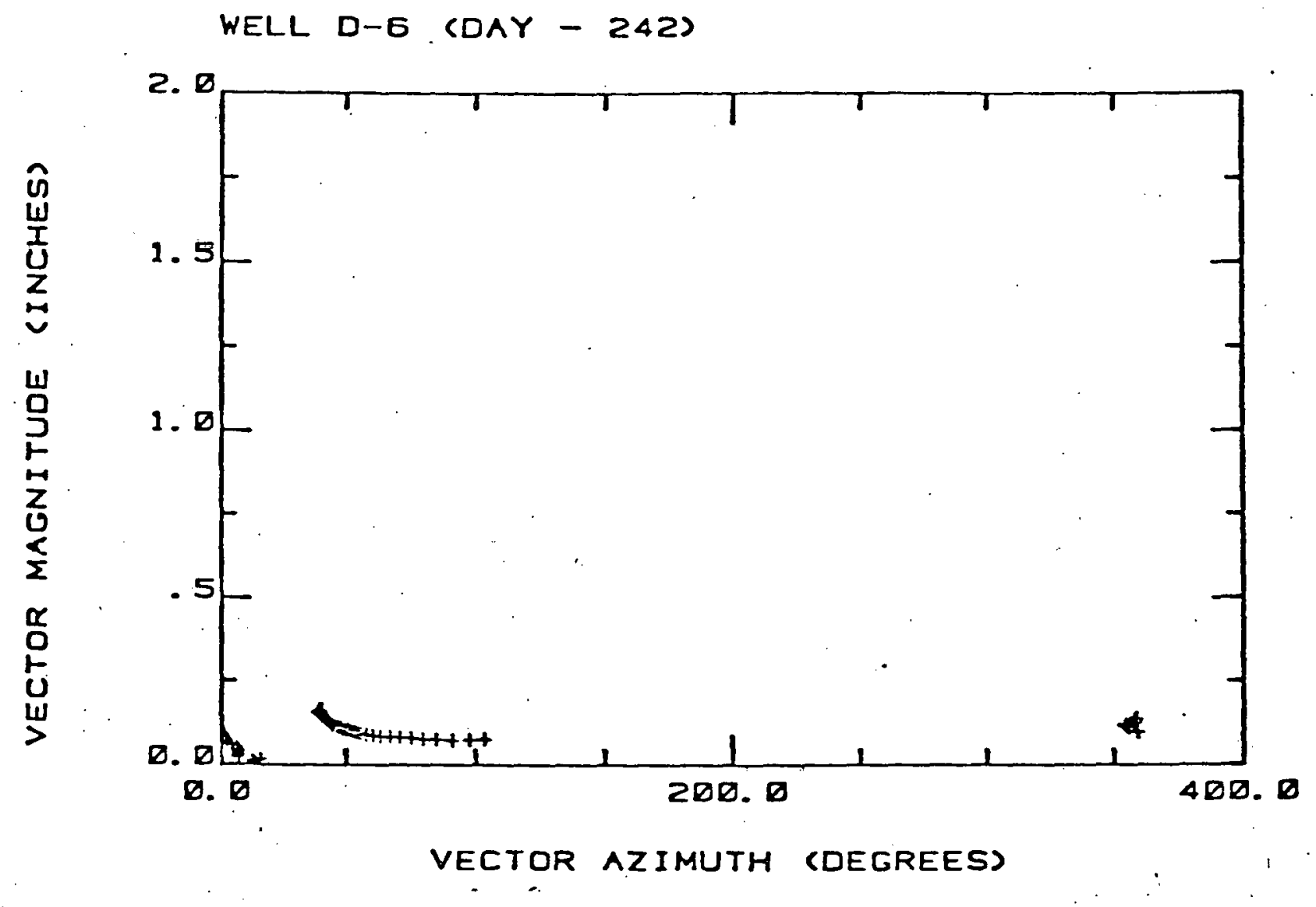

Figure 5-10. Orientation of vector motion occurring 12 days after start of coal burn. 


\section{1 \\ PREDOMINANT DEFLECTION PLANES}

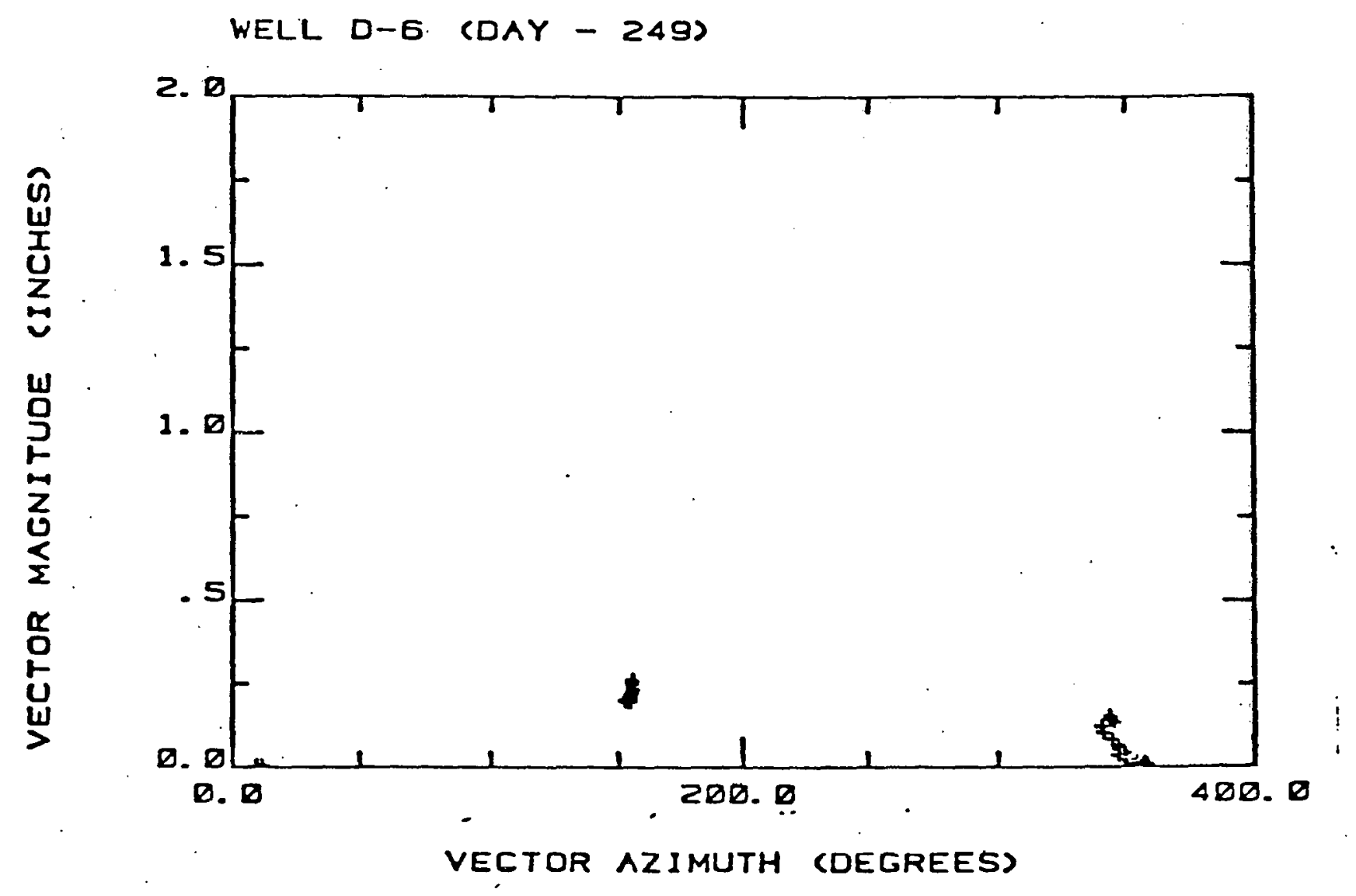

Figure 5-11. Orientation of vector motion occurring 19 days after start of coal burn. 
PREDOMINANT DEFLECTION PLANES

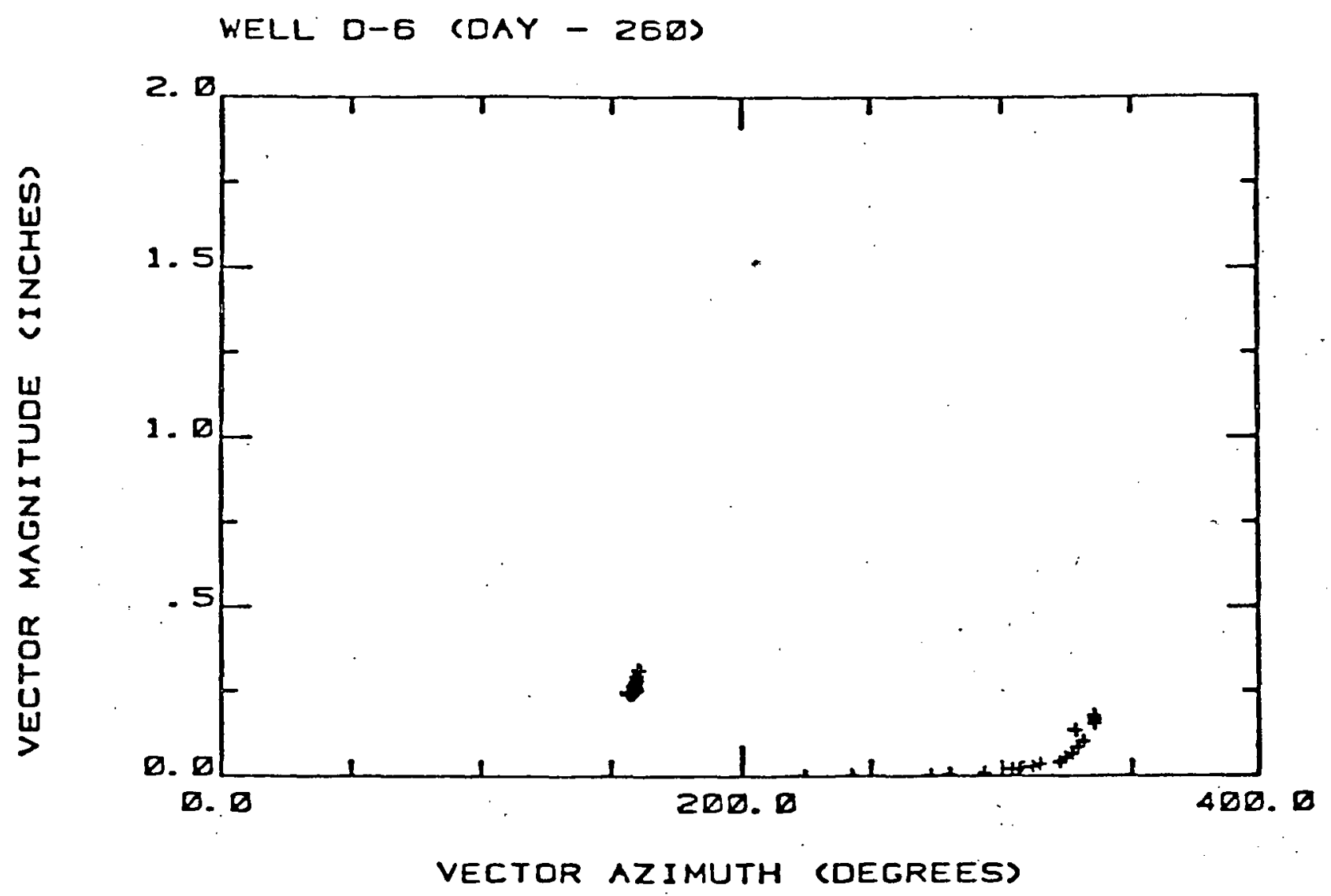

Figure 5-12. Orientation of vector motion occurring 30 days after start of coal burn. 


\section{PREDOMINANT DEFLECTION PLANES}

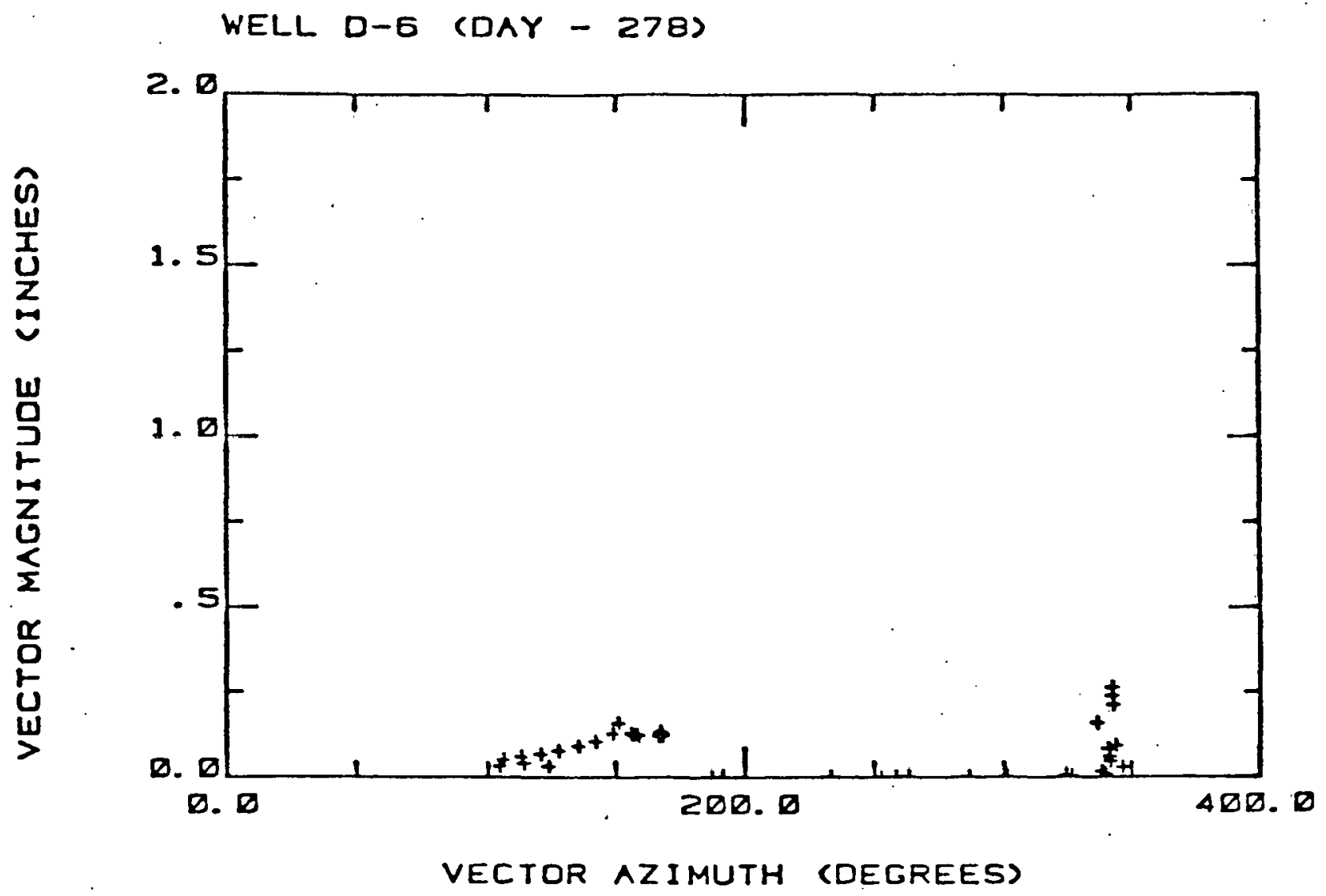

Figure 5-13. Orientation of vector motion occurring 48 days after start of coal burn. 


\section{REFERENCES}

Dahlman, O. and Israelson, H., 1977, Monitoring Underground Nuclear Explosions (Elsevier Scientific Publishing Co., New York).

Ganow, H., 1978, "Hoe Creek III Geotechnical Experiment" in Hoe Creek No 3 Pre Operational Report, R. W. Hill Ed., Lawrence Livermore National Laboratory, UCID-18013, pp.32-38.

Hi11, R.W., 1980, "Hoe Creek No. 3: First Long-Term Underground Coal Gasification Experiment with Oxygen-Steam Injection,". in Energy and Technology Review, Lawrence Livermore National Laboratory, UCRL-52000-80-5, pp.17-25.

Nordyke, M.D., 1981, "Verifying Compliance with the Test Ban Treaties," in Energy and Technology Review, Lawrence Livermore National Laboratory, UCRL-52000-81-6, pp.19-29.

Proskurjakova, T.A., Rykunov, L.N., and Savarensky, E.F., 1973, "Some Results of Study of the Microseisms in the USSR, " Pure and Applied Geophysics (PAGEOPH) 102, 290-295. 
APPENDIX A. Logging Results from South Heater Drift, Spent Fuel Test--Climax

The Spent-Fuel Test being conducted by LLNL in the Climax granite of the Nevada Test Site, involved the drilling of many boreholes. Appendix $A$ and Appendix B of this document are comprised of the core logs for holes that were drilled in two of the three drifts of that facility, Figure A-1, for the placement of electrical heaters. These electrical heaters were used to simulate the heat loading experienced in an actual repository. Therefore the holes were designated by drift and by hole number, i.e., South Heater Hole \#1 for the South Heater Drift Heater Hole \#1. (Note that heater holes are numbered from west to east; i.e., the westernmost holes in both the north and south drift's is designated \#1.) South drift cores were logged by Marianne Doyle (see Report 1). Abbreviations used were kept to a minimum and represent standard usage where possible. For further understanding of the abbreviations see the glossary of terms.

\section{GLOSSARY OF TERMS}

\section{ALT Alteration}

Core Run The number of the cored interval or segment of core removed. This is essentially the sequential numbering of the core barrels removed.

D On the core run information, this refers to footage drilled. This information was taken from the driller's logs and from the F\&S inspector's records.

FSP Feldspar

Jt Joint

MB Mechanical Break. This is distinguished from breaks along joints. Mechanical breaks are those that propagate across solid rock.

NR Not Recovered

QTZ Quartz

$R \quad$ On the core run information, this refers to footage recovered. This information is from the driller's logs and from the F\&S inspector's records.

RQD Rock Quality Designation. Percentage of unbroken core recovered as defined by Deere and others.

SR. Sample Removed prior to logging. 


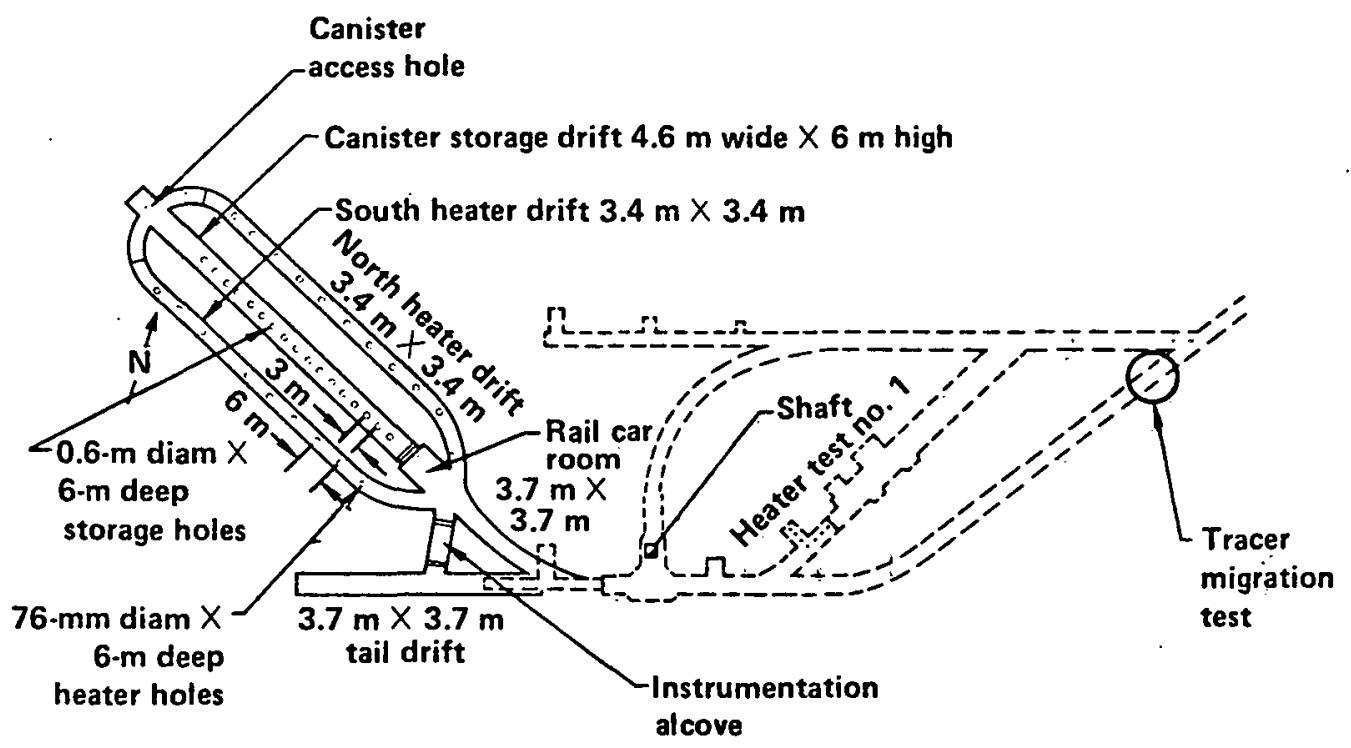

-- Existing workings
- New construction

FIG. A-1 Layout of the Spent Fuel Test facility and adjacent workings 


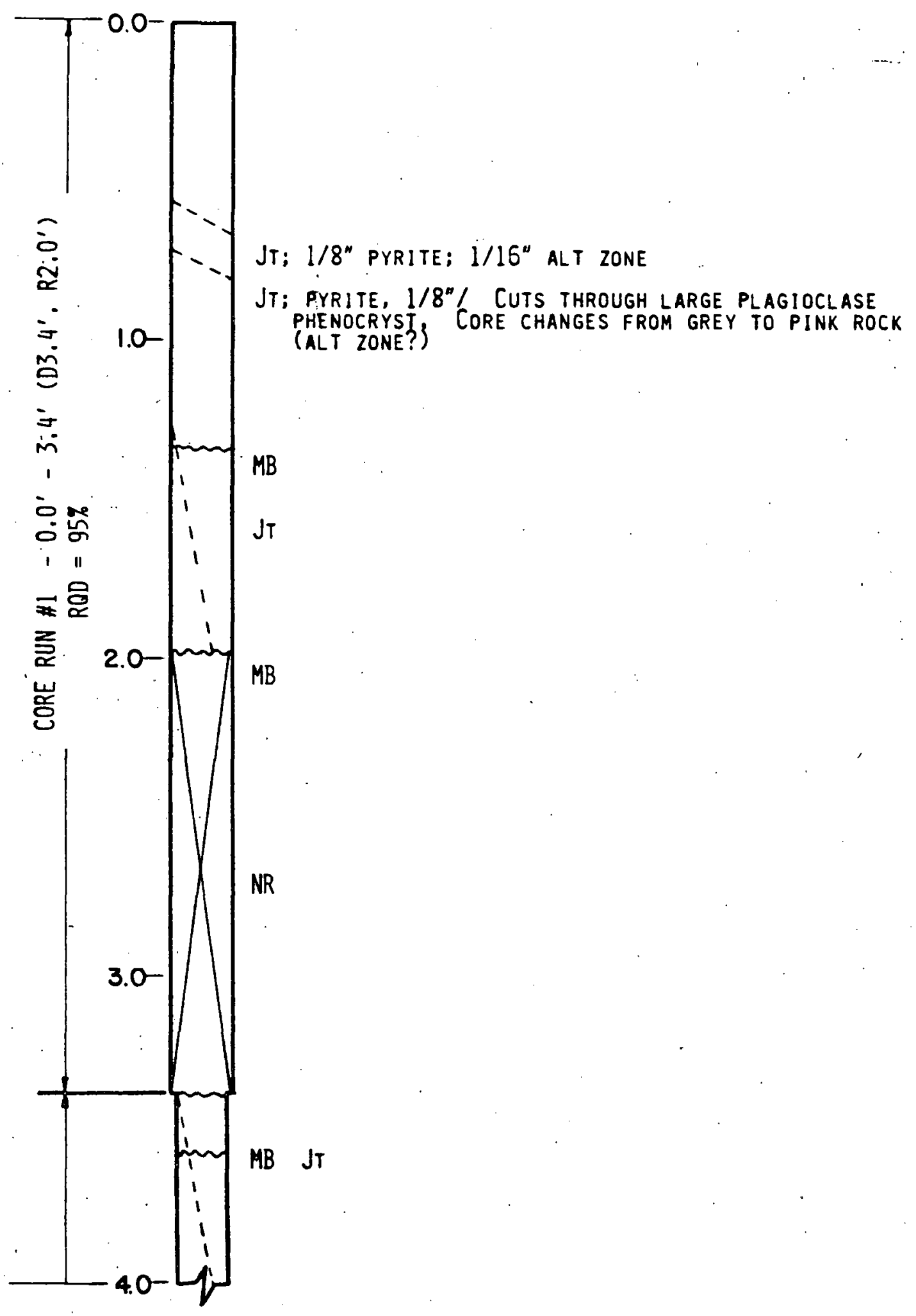

FIG. A-2a South Heater Hole \#1 


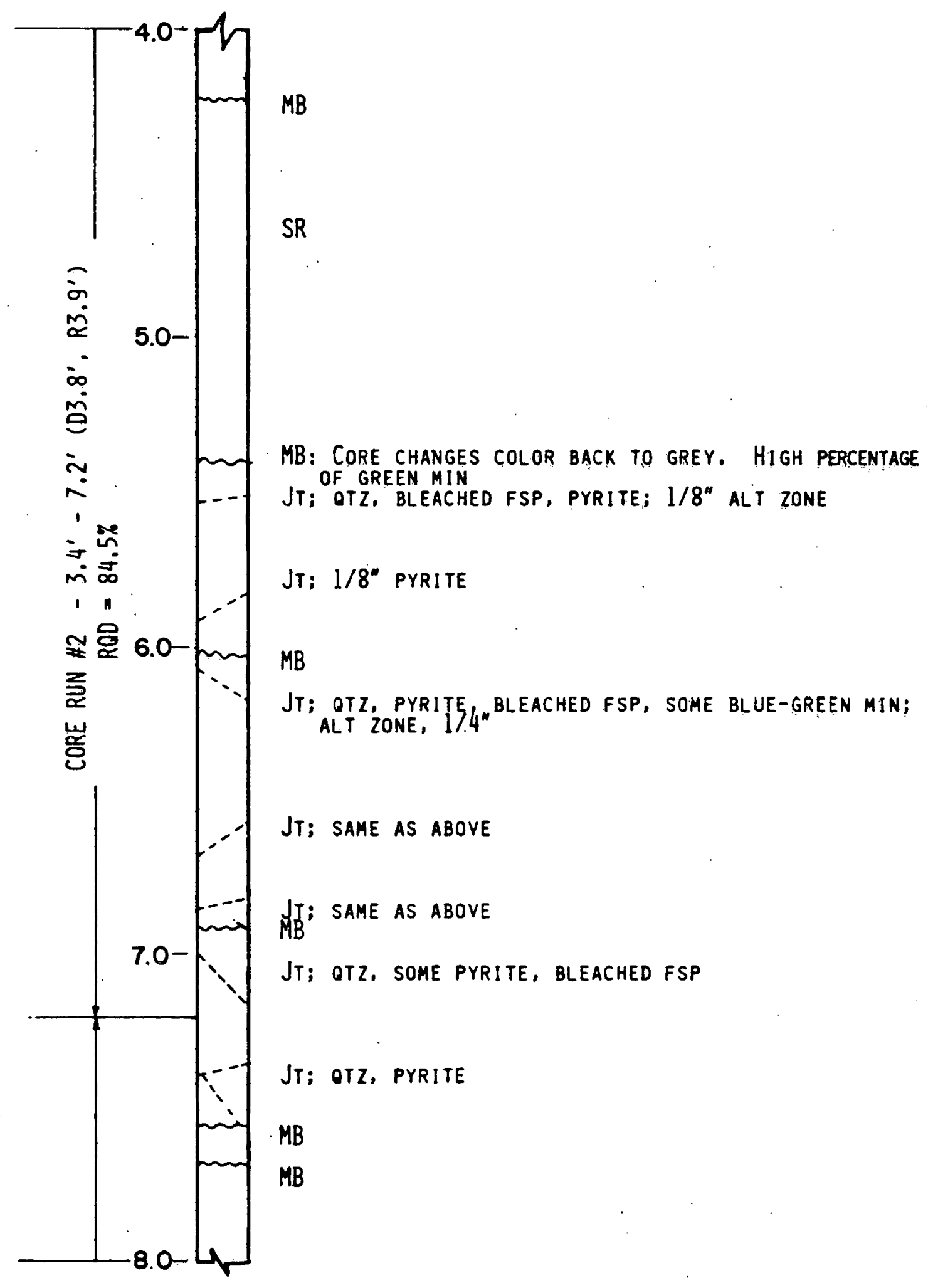

FIG. A-2b (SHH-I) 


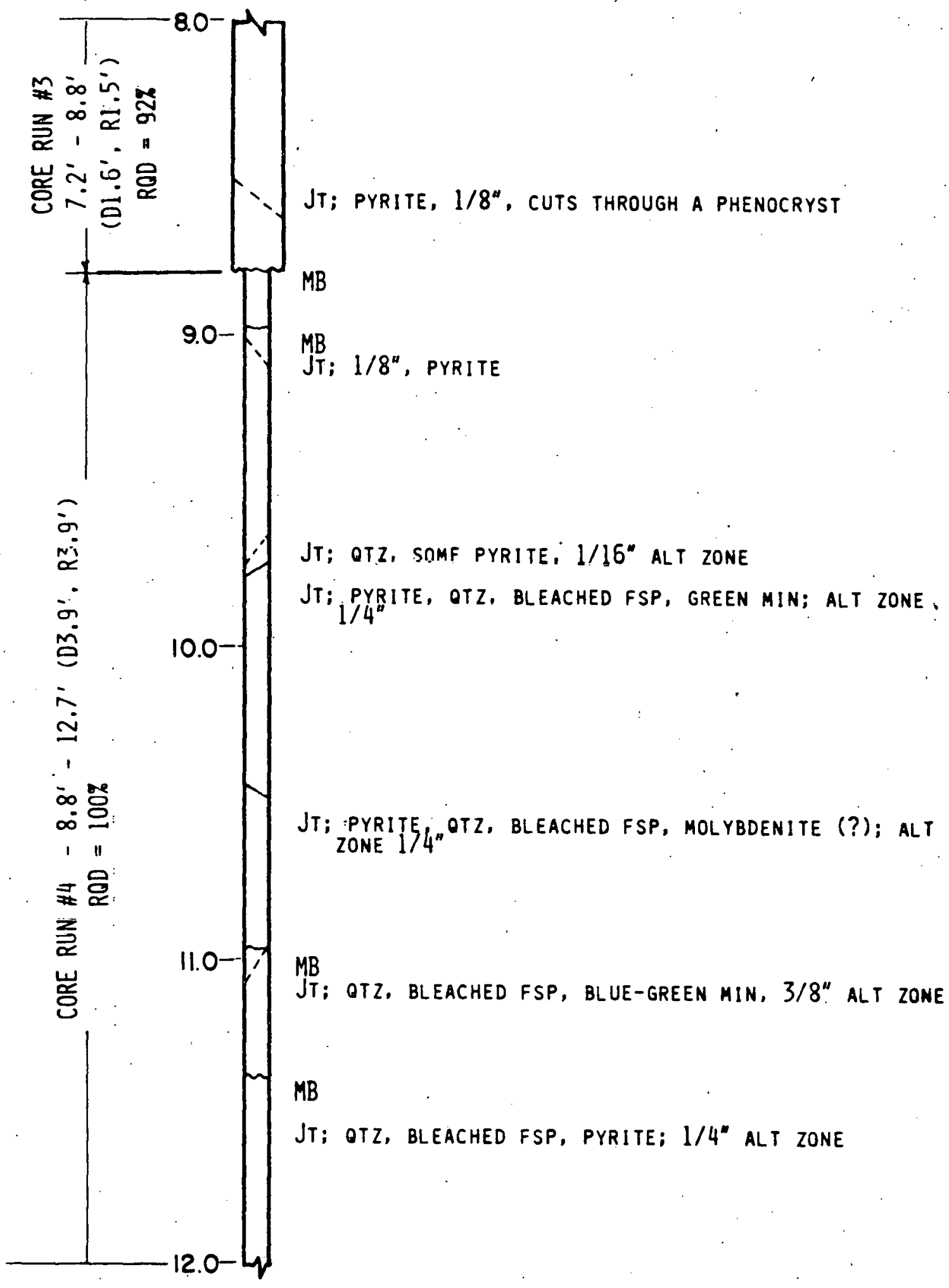

FIf. A-2C (SHH-1). 


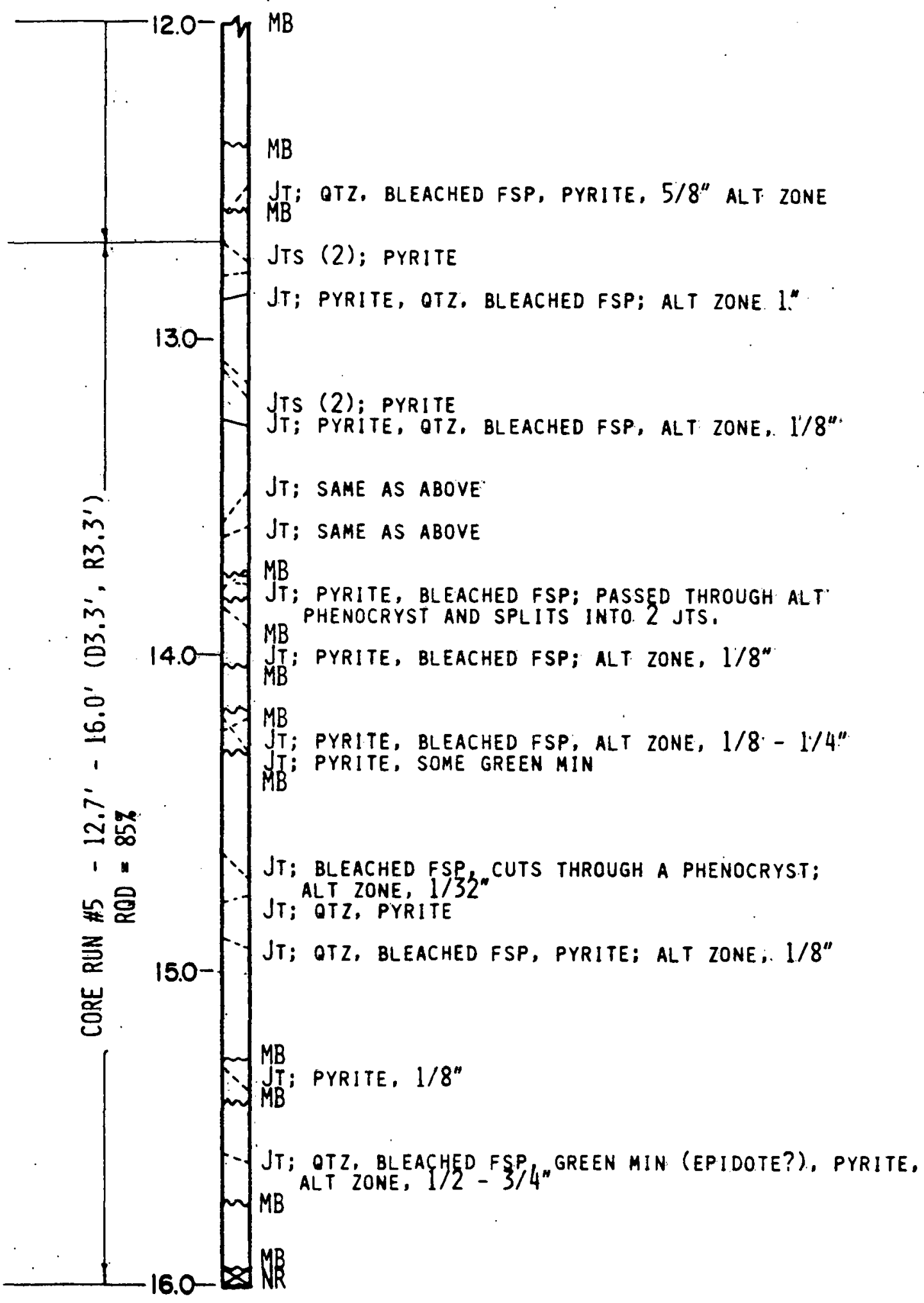

FIG. A-2d (SHH-T) 


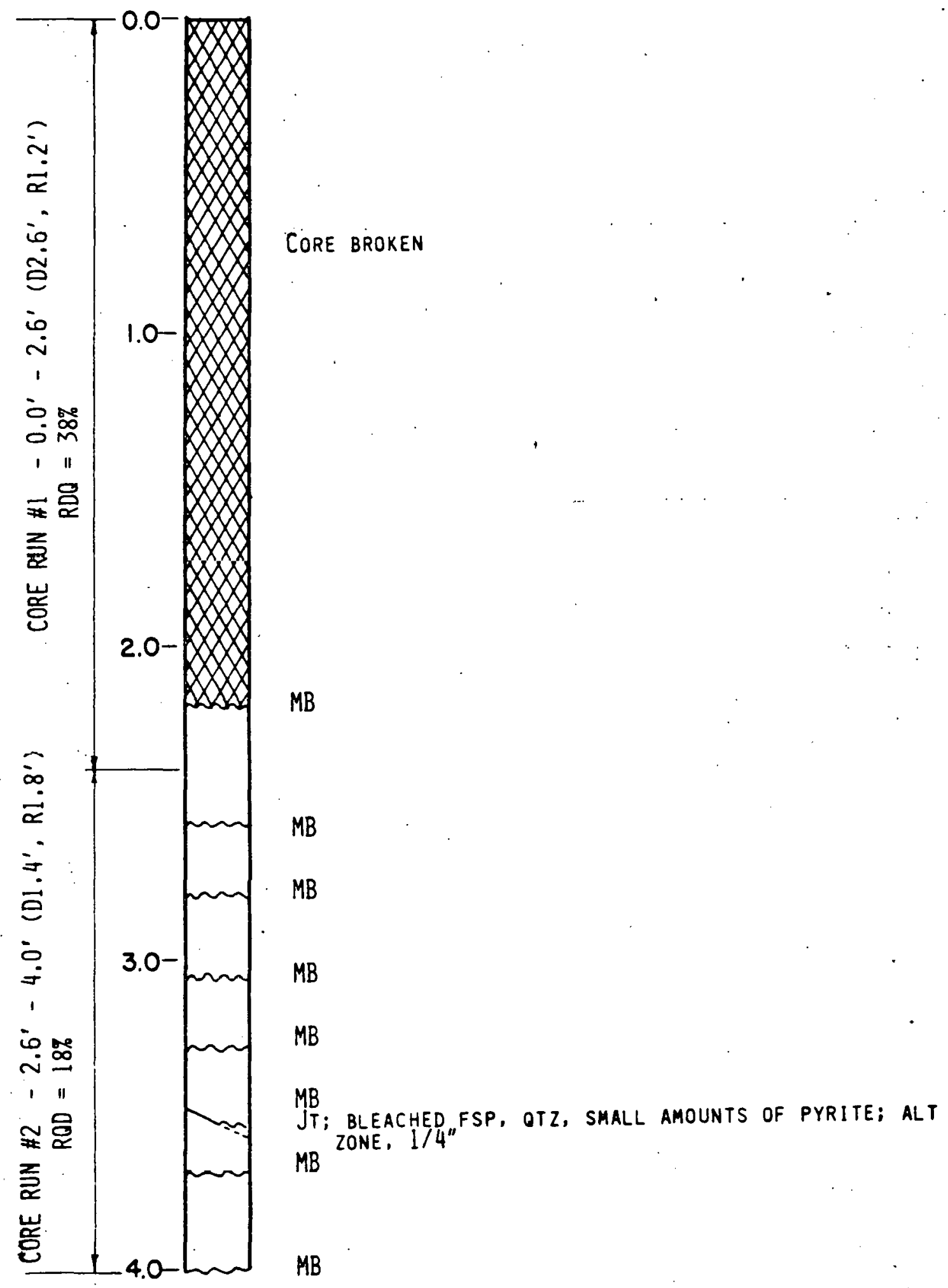

FIG. A-3a South Heater Hole \#2 


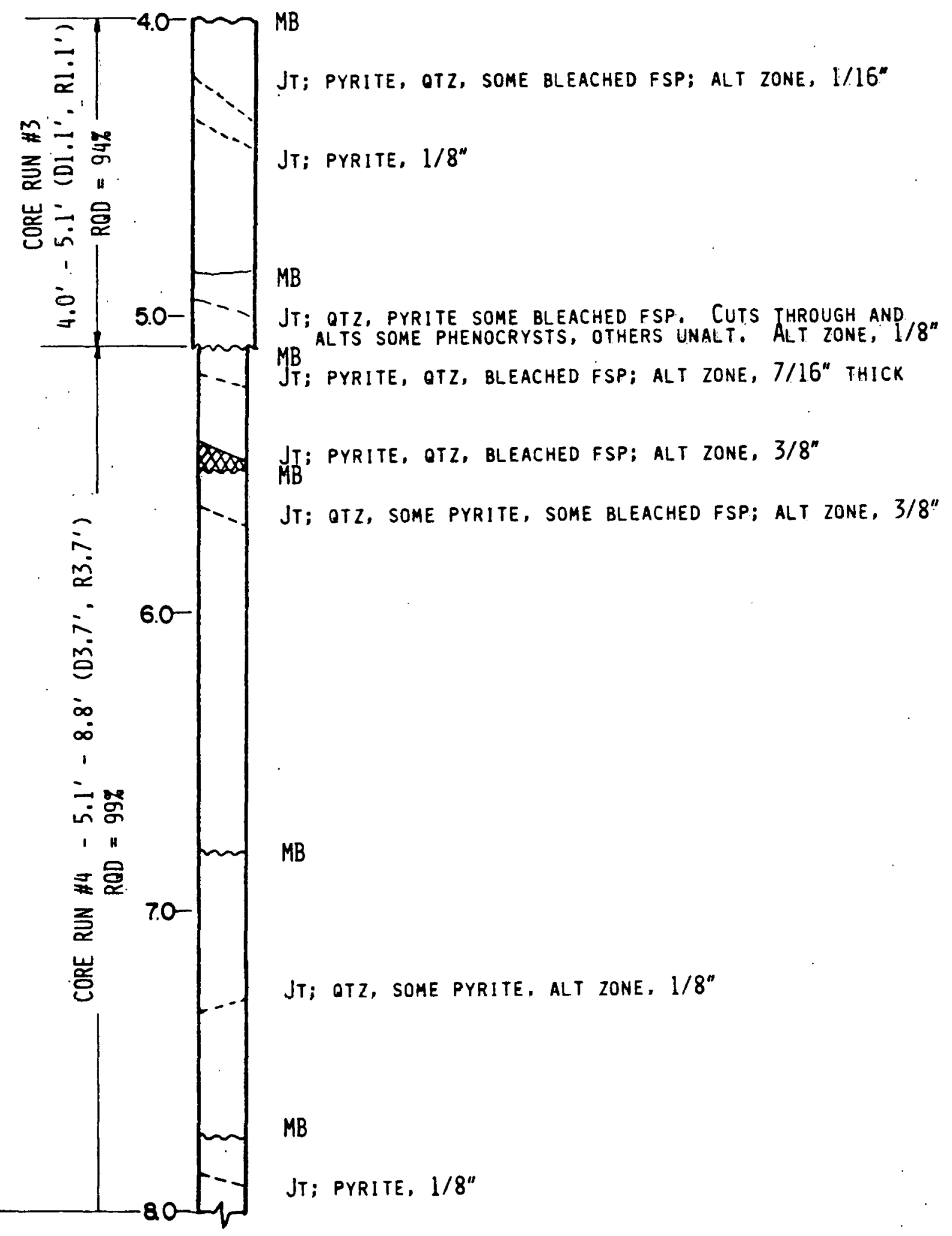

FIG. A-3b (SHH-2) 


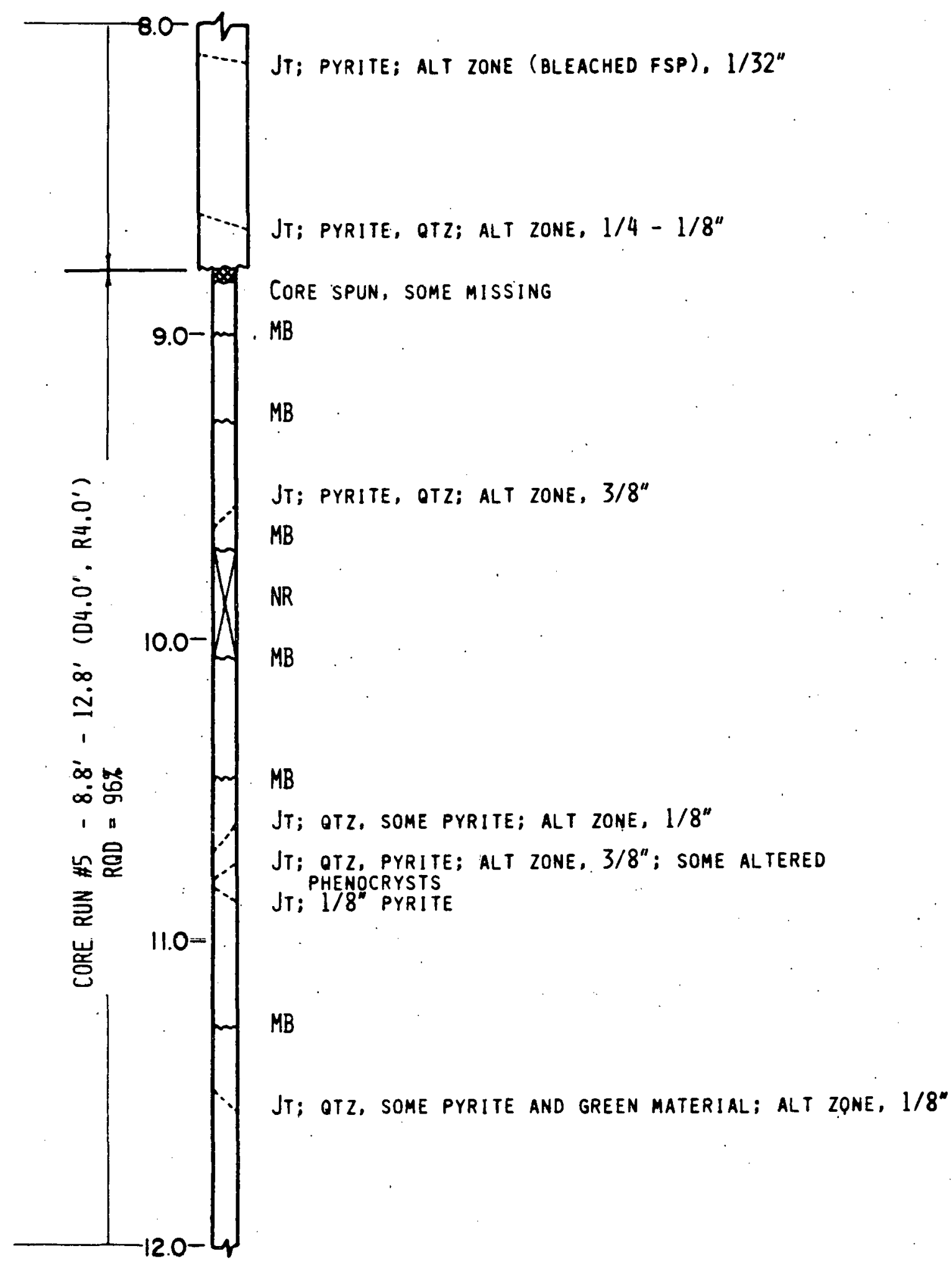

FIG. $A-3 c \quad(S H H-2)$ 


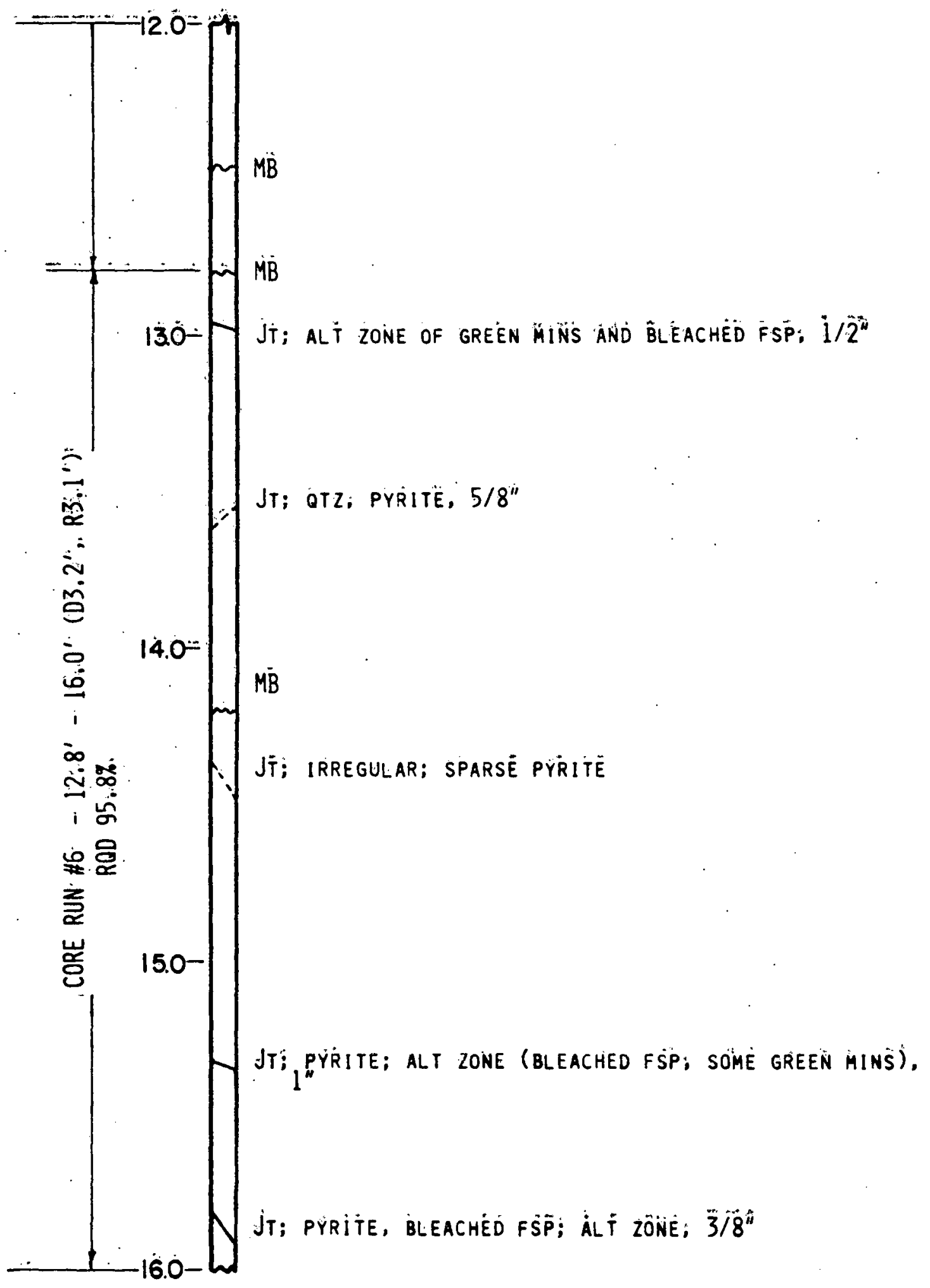

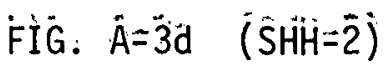




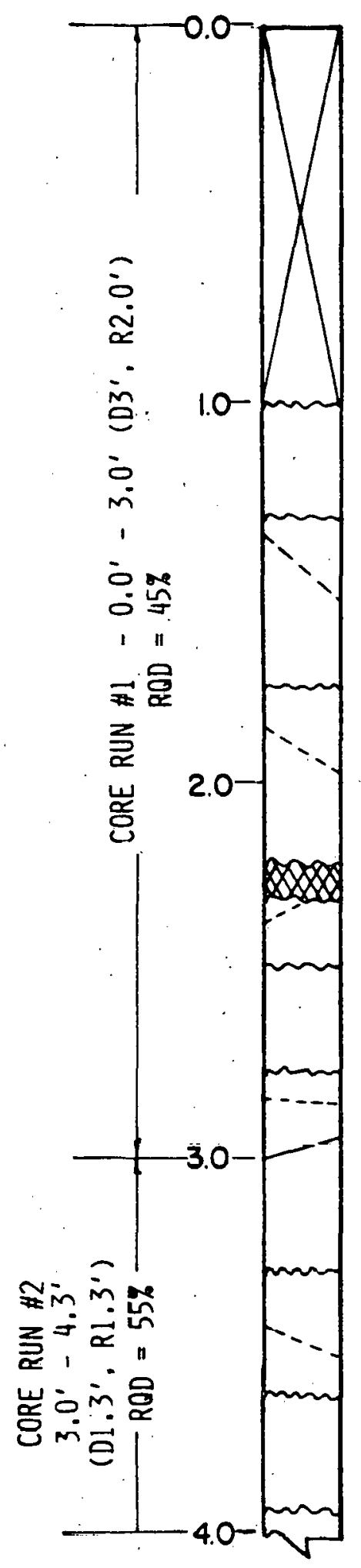

NR

MB

$M B$

JT; PYRITE, BLEACHED FSP ALT ZONE, $1 / 16^{\prime \prime}$

MB

JT; $194^{7}$. BLEACHED FSP. ALTS PHENOCRYSTS; ALT ZONE,

MB

CORE BROKEN

MB

MB: OTZ, BLEACHED FSP; ALT ZONE, $1 / 4^{\prime \prime}$

$M B$

JT; IRREGULAR; OTZ, BLEACHED PLAGIOCLASE; ALT ZONE, IT; PYRITE, otZ, BLEACHED FSP; ALT ZONE, 1/4"

$M B$ JT; PYRITE, OTZ, BLEACHED FSP; ALTS FSP IT CUTS MB

$M B$

FIG. A-4a South Heater Hole \#3 


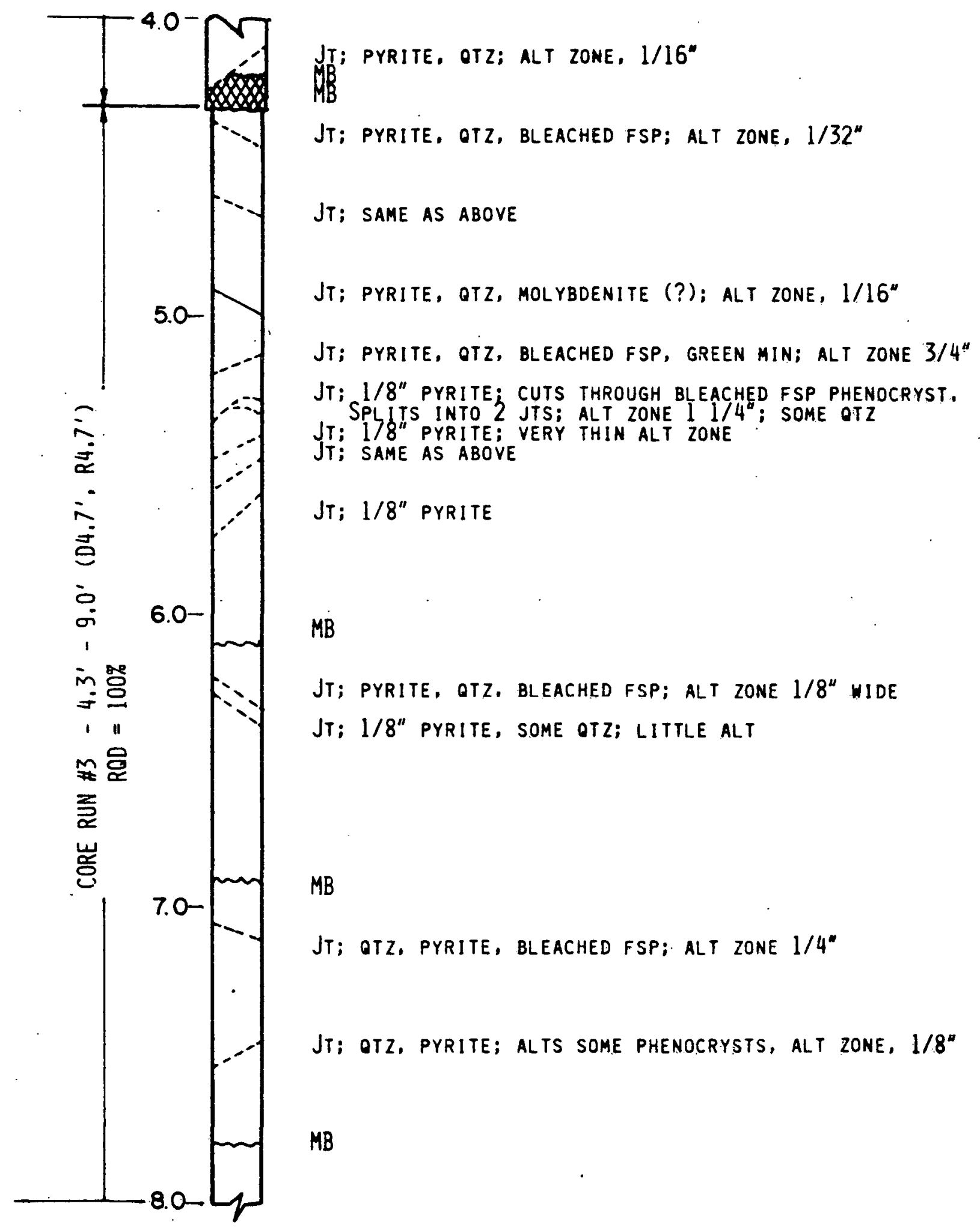

FIG. A-4b (SHH-3) 


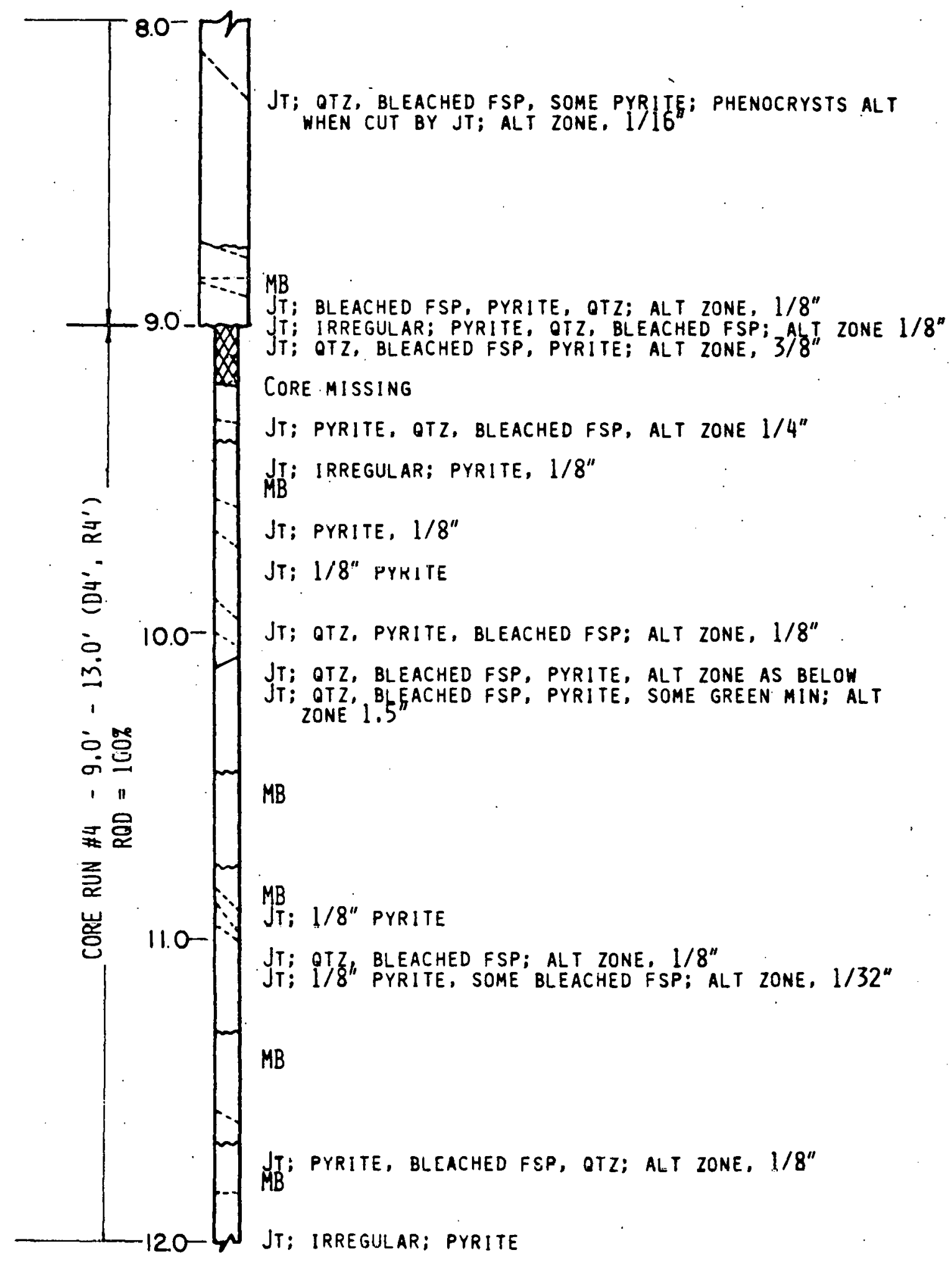

FIG, A-4C (SHH-3) 


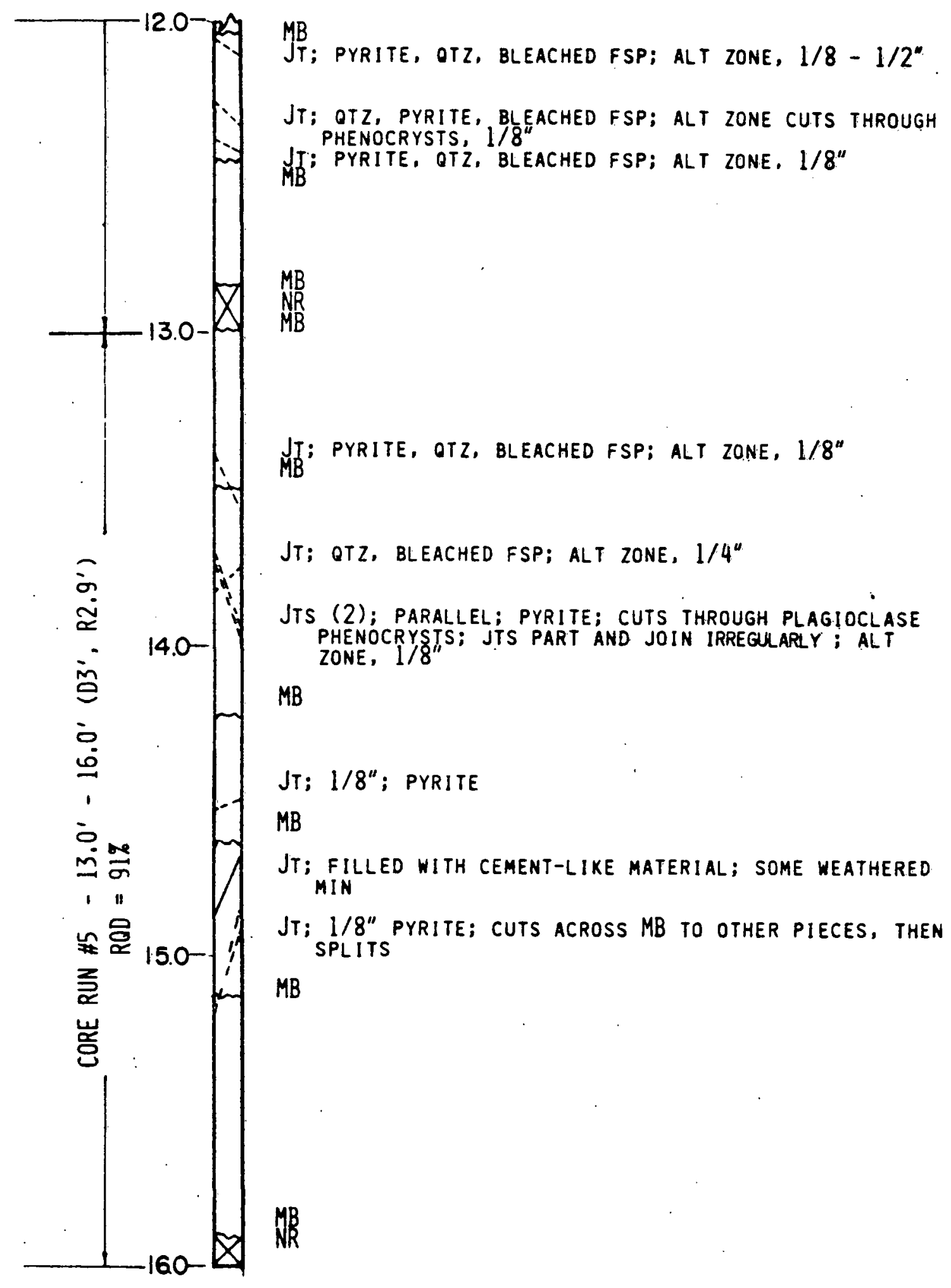

FIG. A-4d (SHH-3.) 


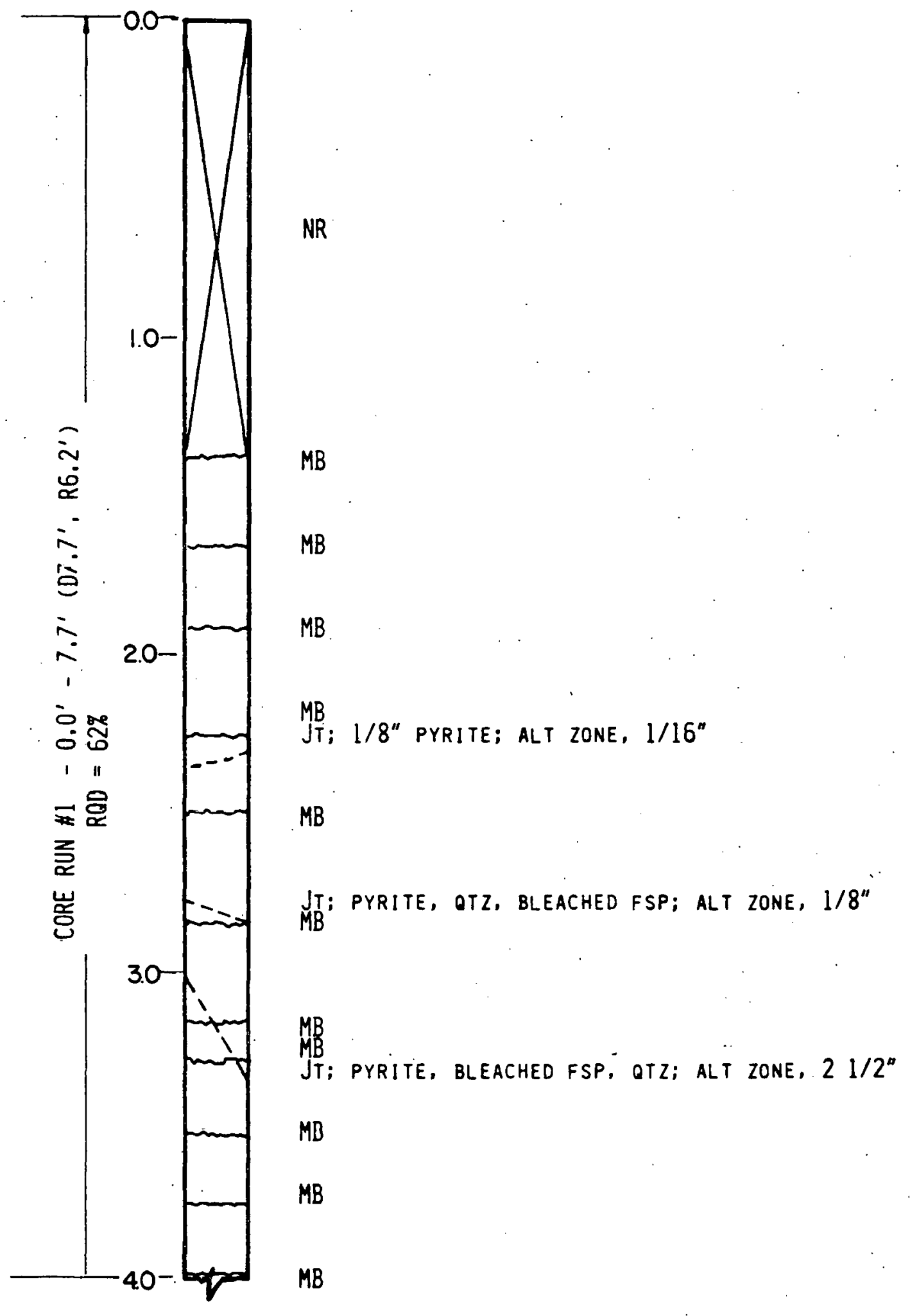

FIG. A-5a South Heater Hole \#4 


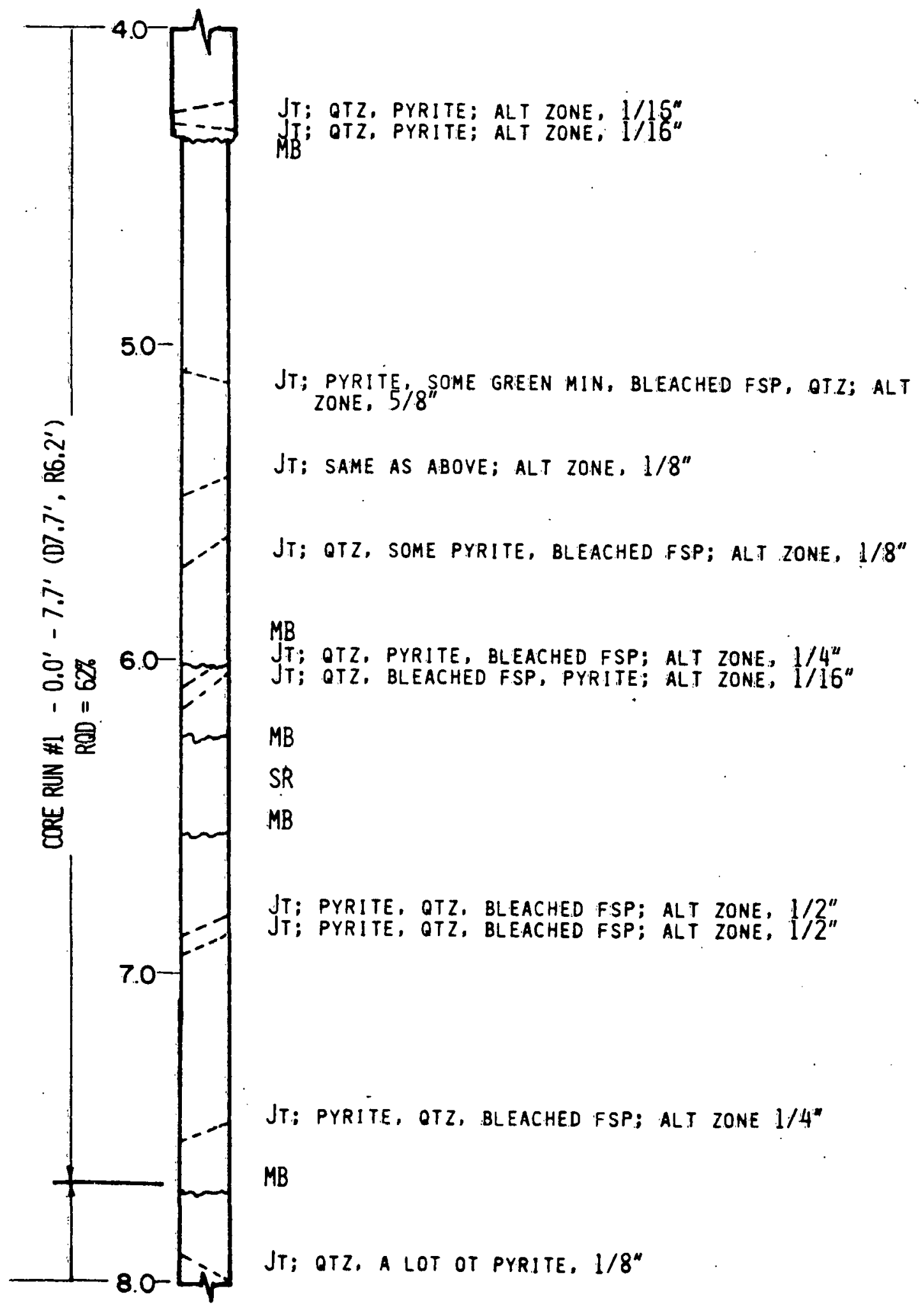

FIG. A-5b (SHH-4) 


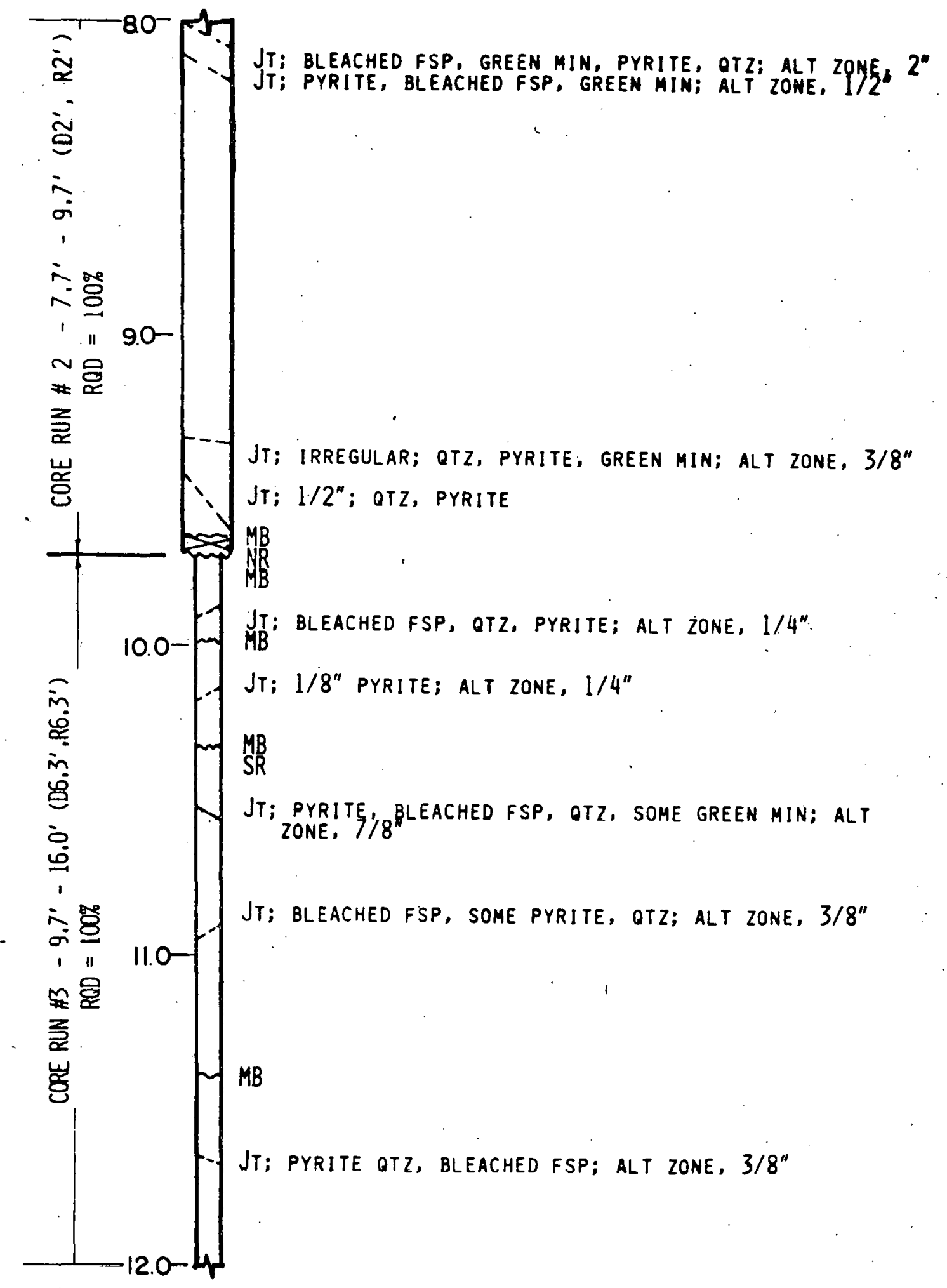

FIG. A-5c (SHH-4) 


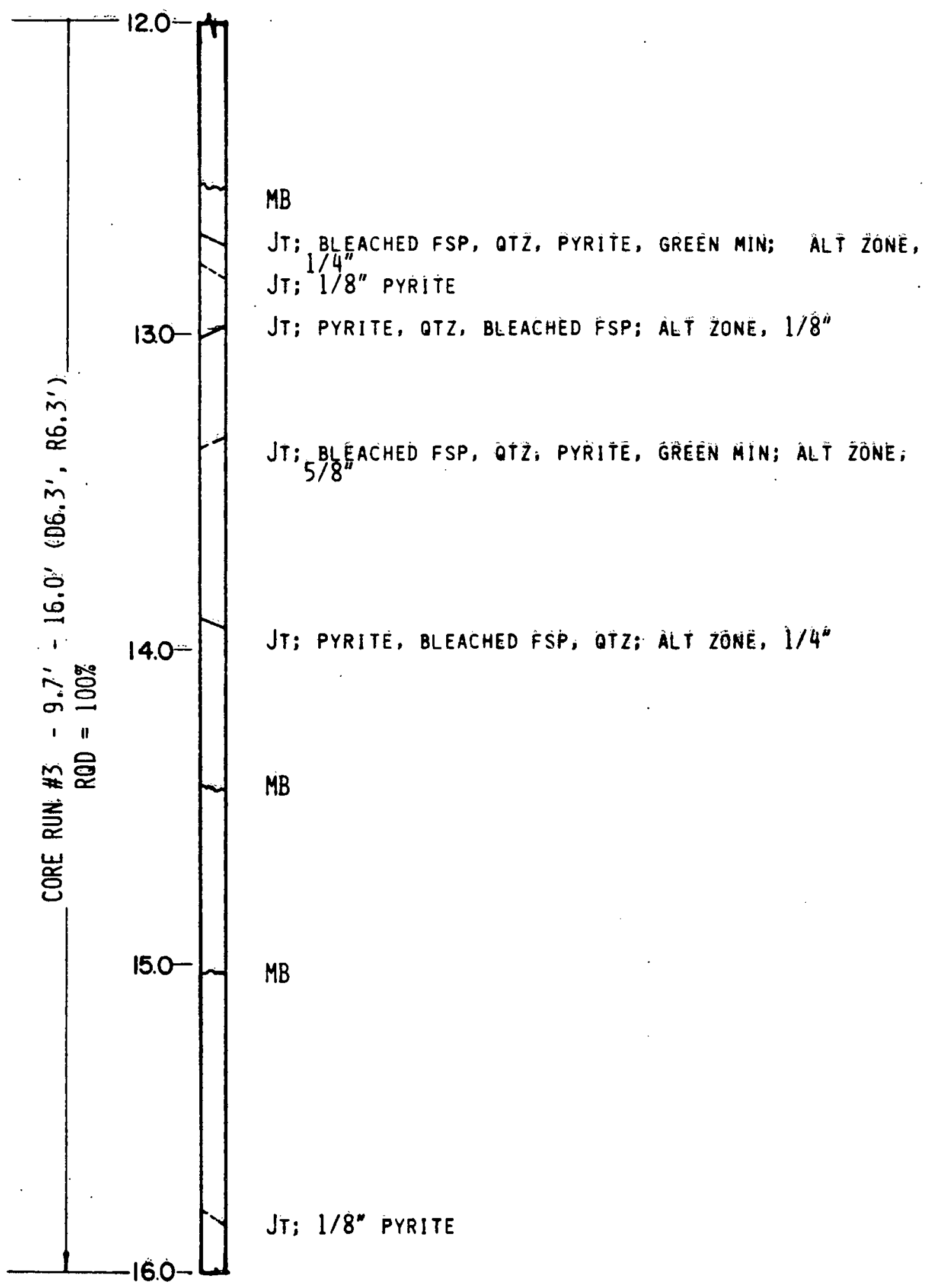

FIG. $A=5 \dot{d} d \quad(S H H-4)$

$-A 18=$ 


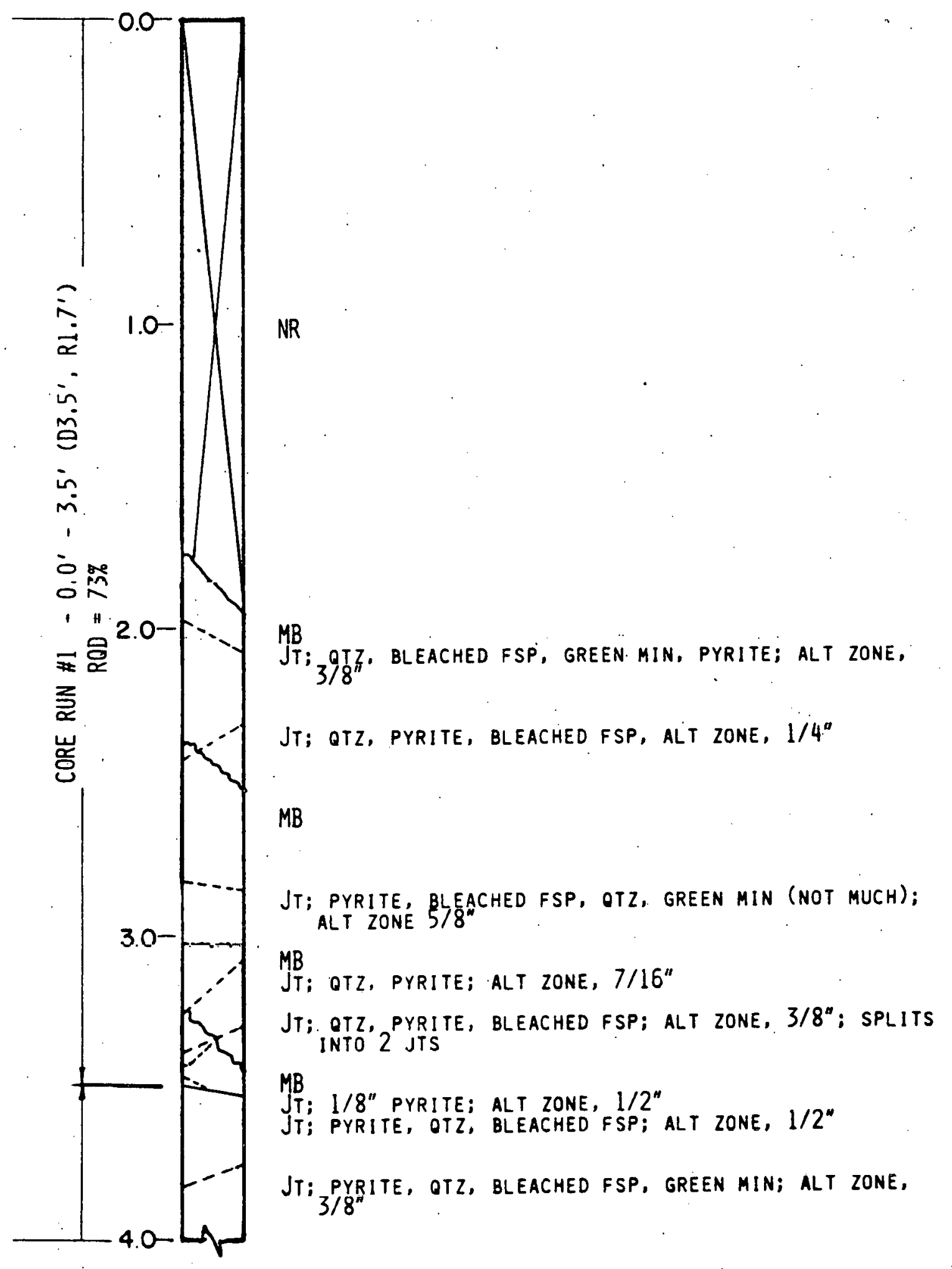

FIG. A-6a South Heater Hole \#5 


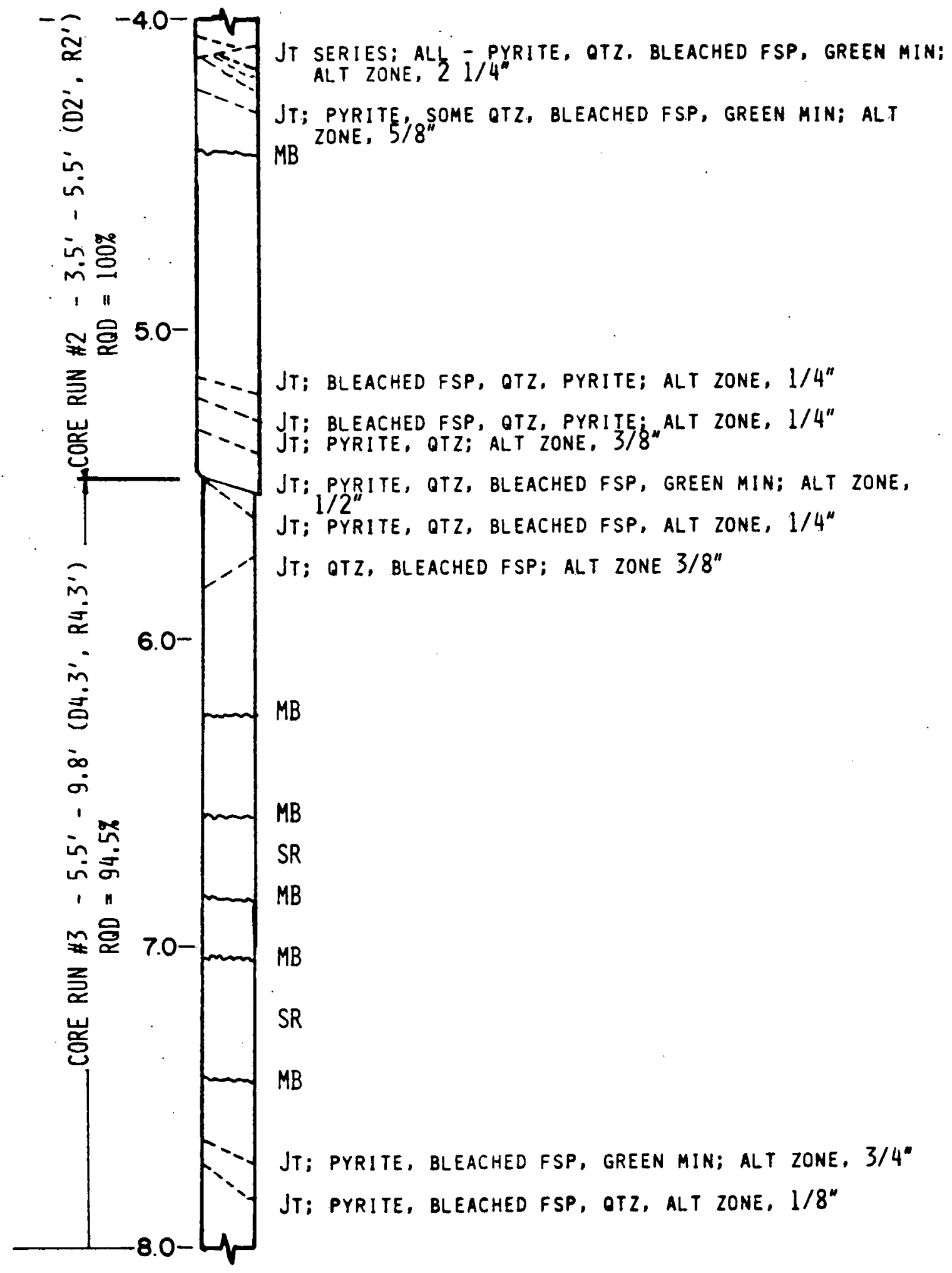

FIG. A-6b (SHH-5) 


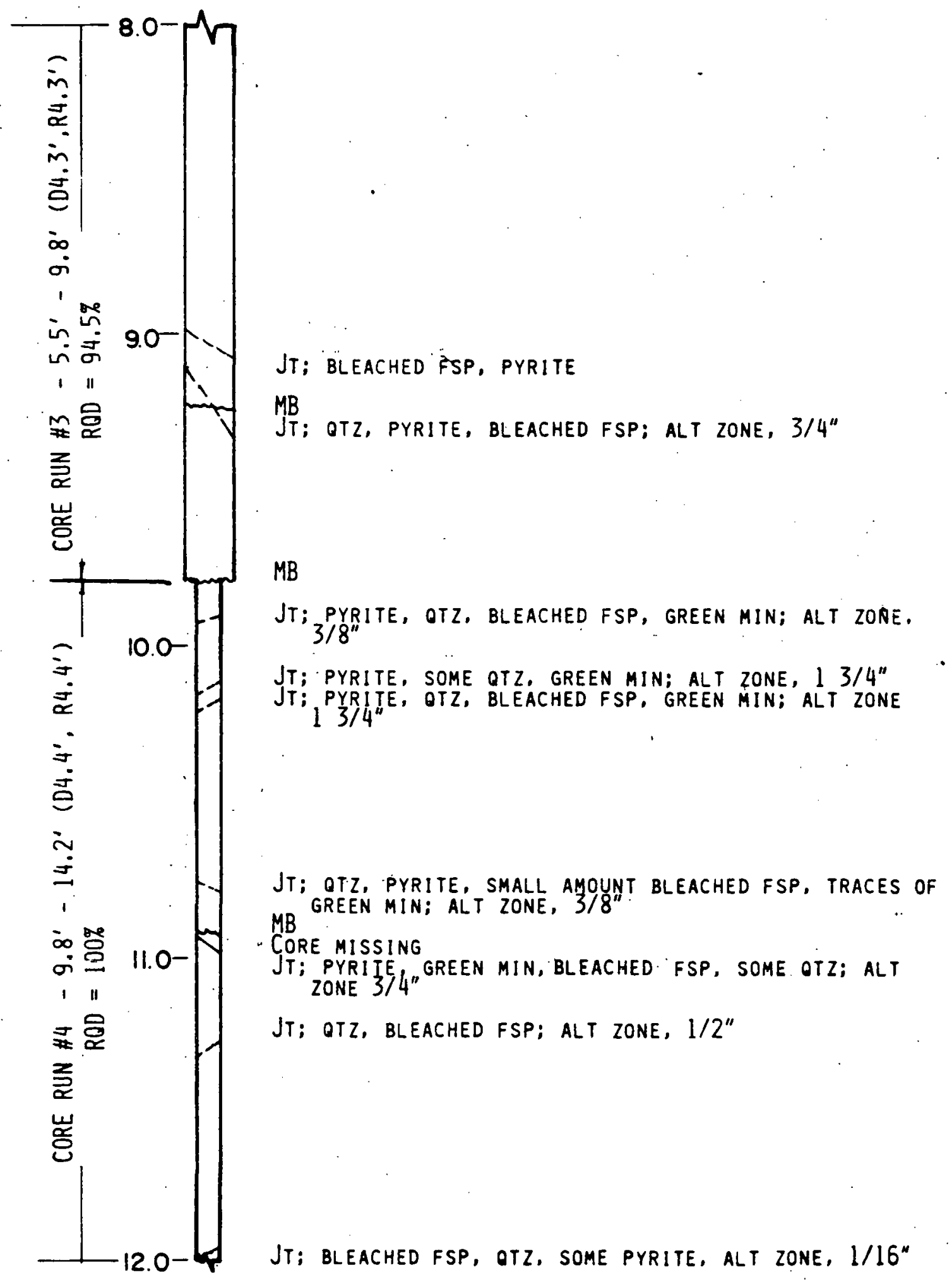

FIG. A-6r. (SHH-5) 


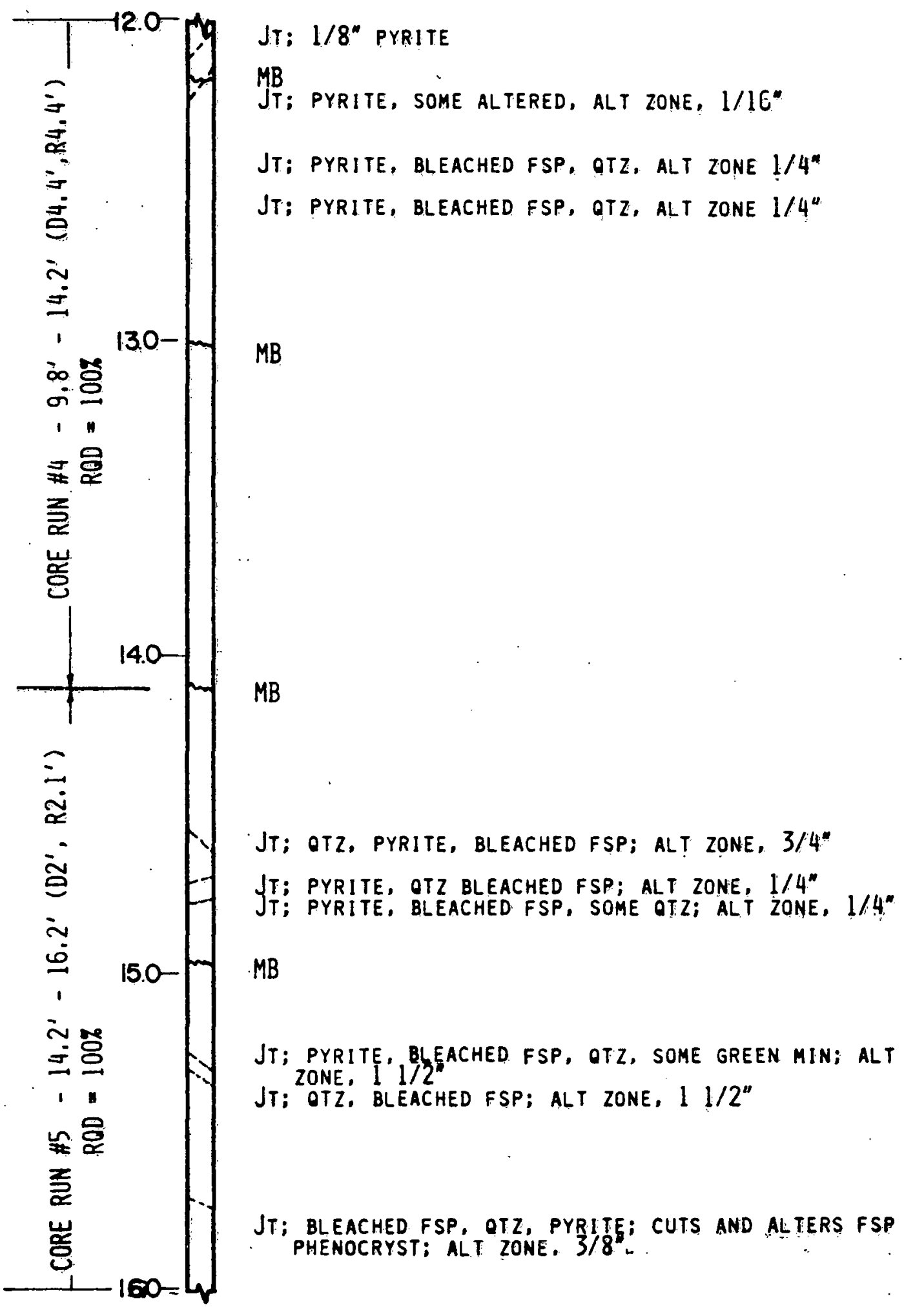

FIG. A-6d (SHH-5) 


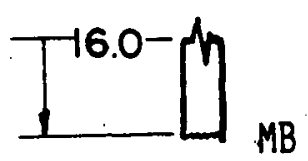

FIG. A-6e (SHH-5)

- A23 - 


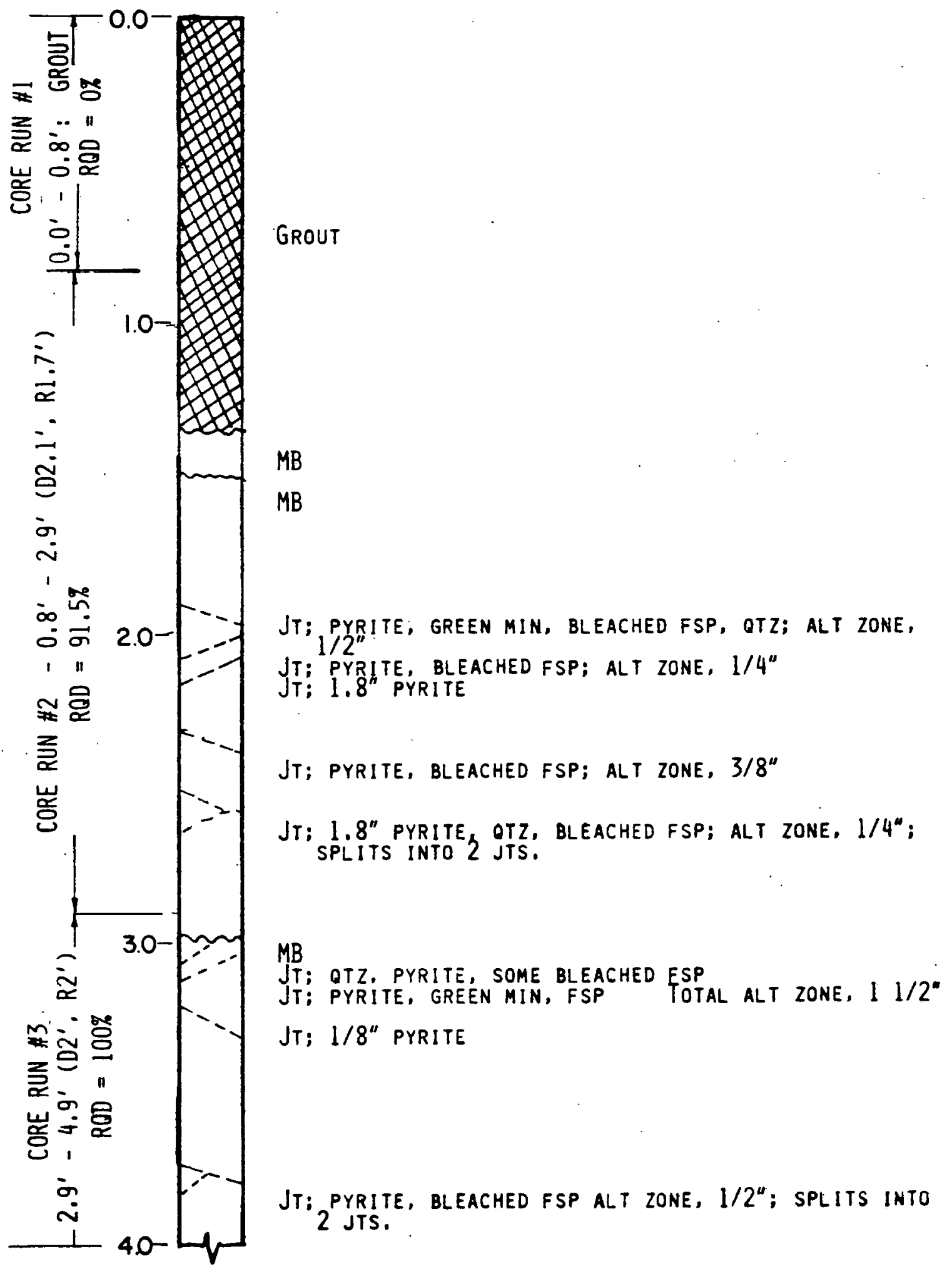

JT; QTZ, PYRITE, SOME BLEACHED ESP
JT; PYRITE, GREEN MIN, FSP JT: 1/8" PYRITE

JT: PYRITE, BLEACHED FSP ALT ZONE, $1 / 2^{*}$; SPLITS INTO

FIG. A-7a South Heater Hole \#6 


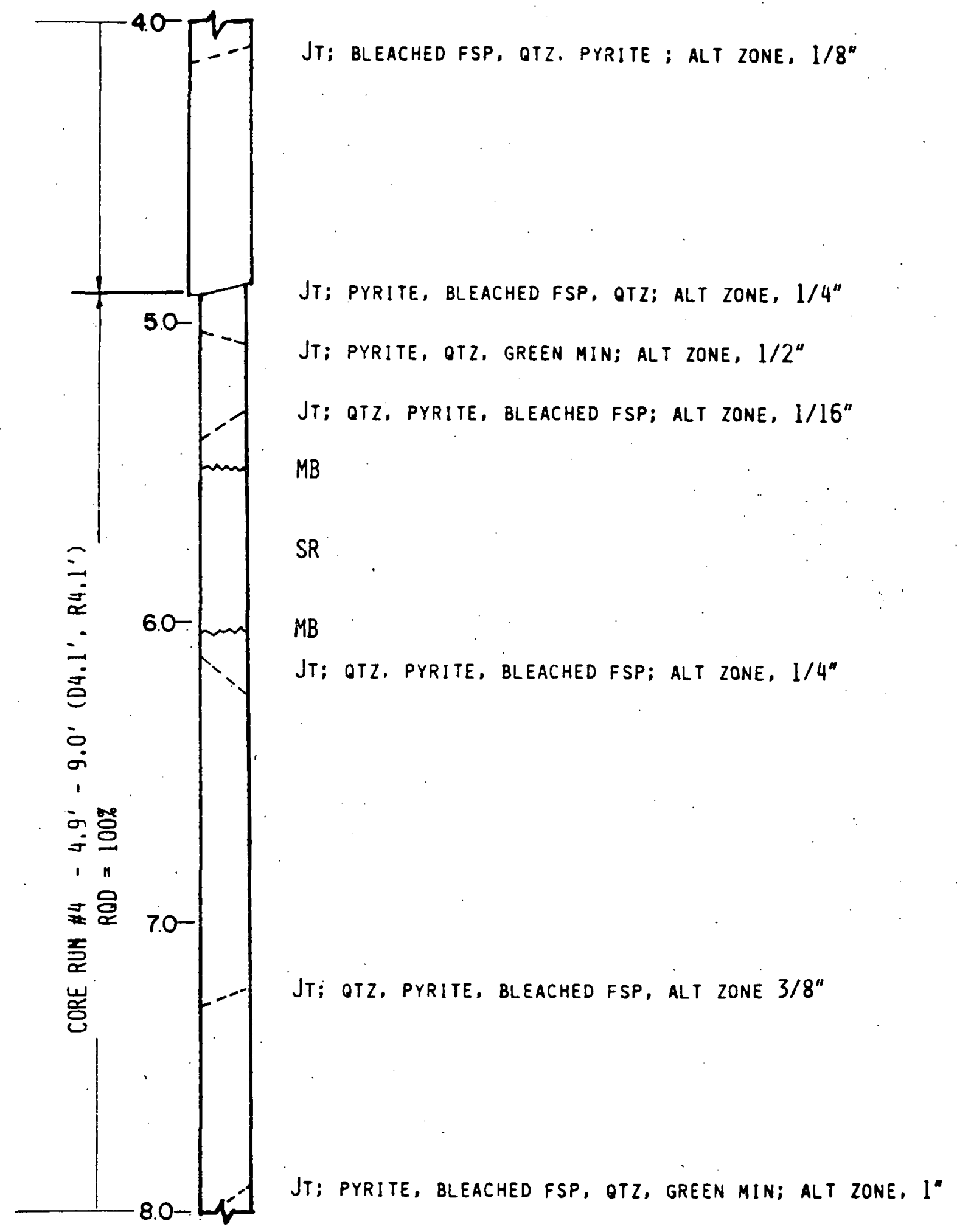

FIG. A-7b (SHH-6) 


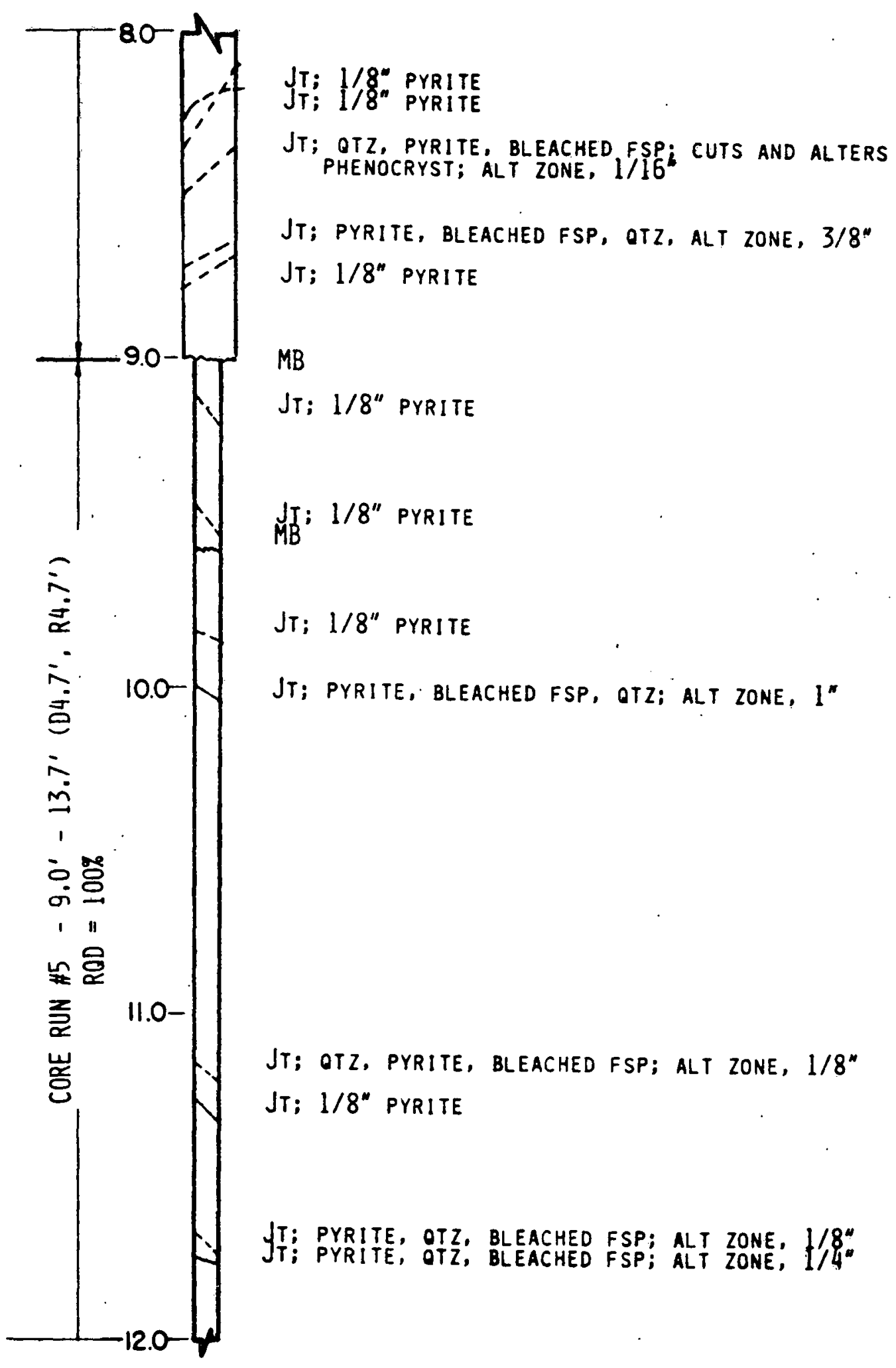

FIG. A-7C (SHH-6) 


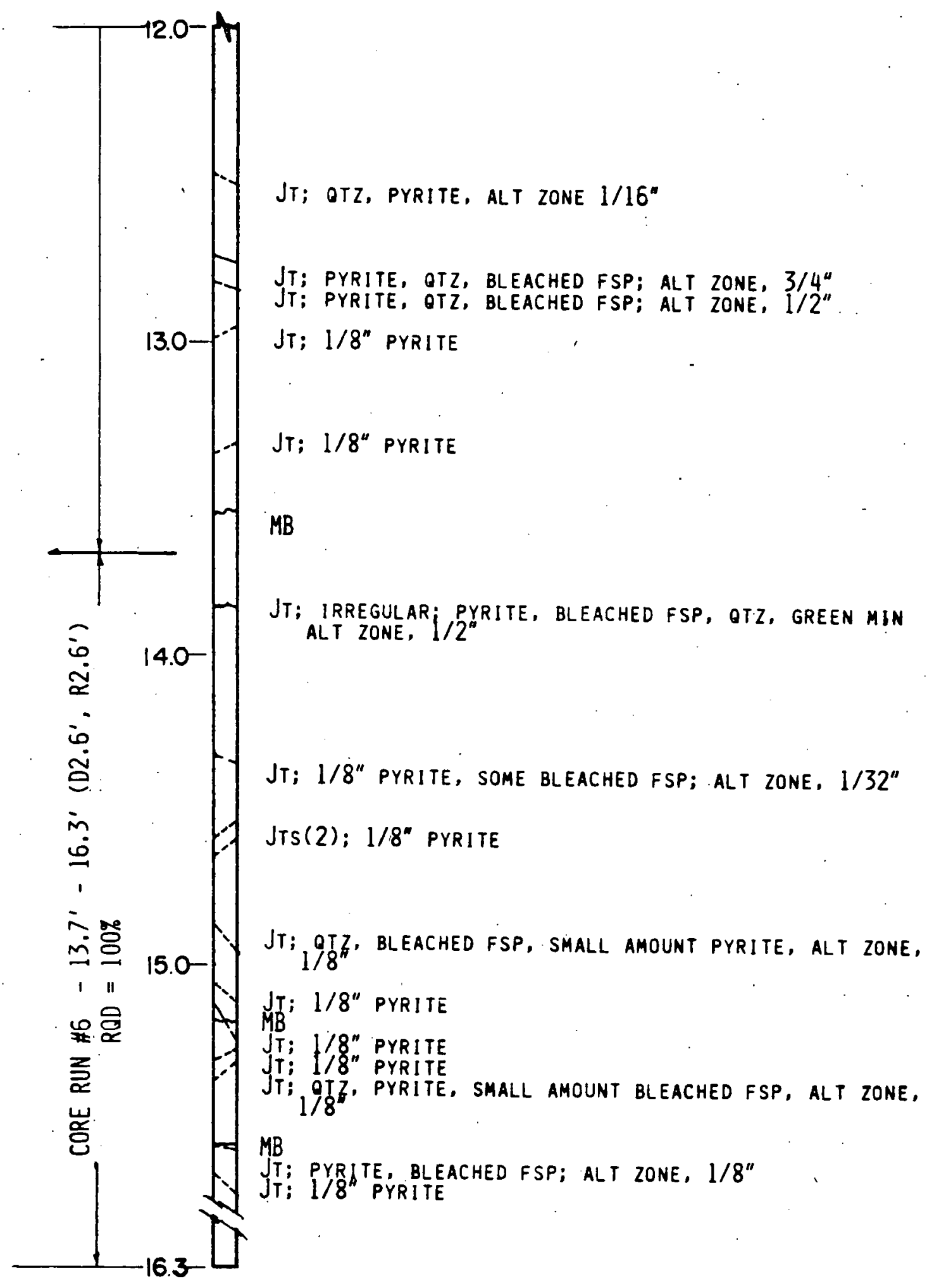

FIG. A-7d (SHH-6) 


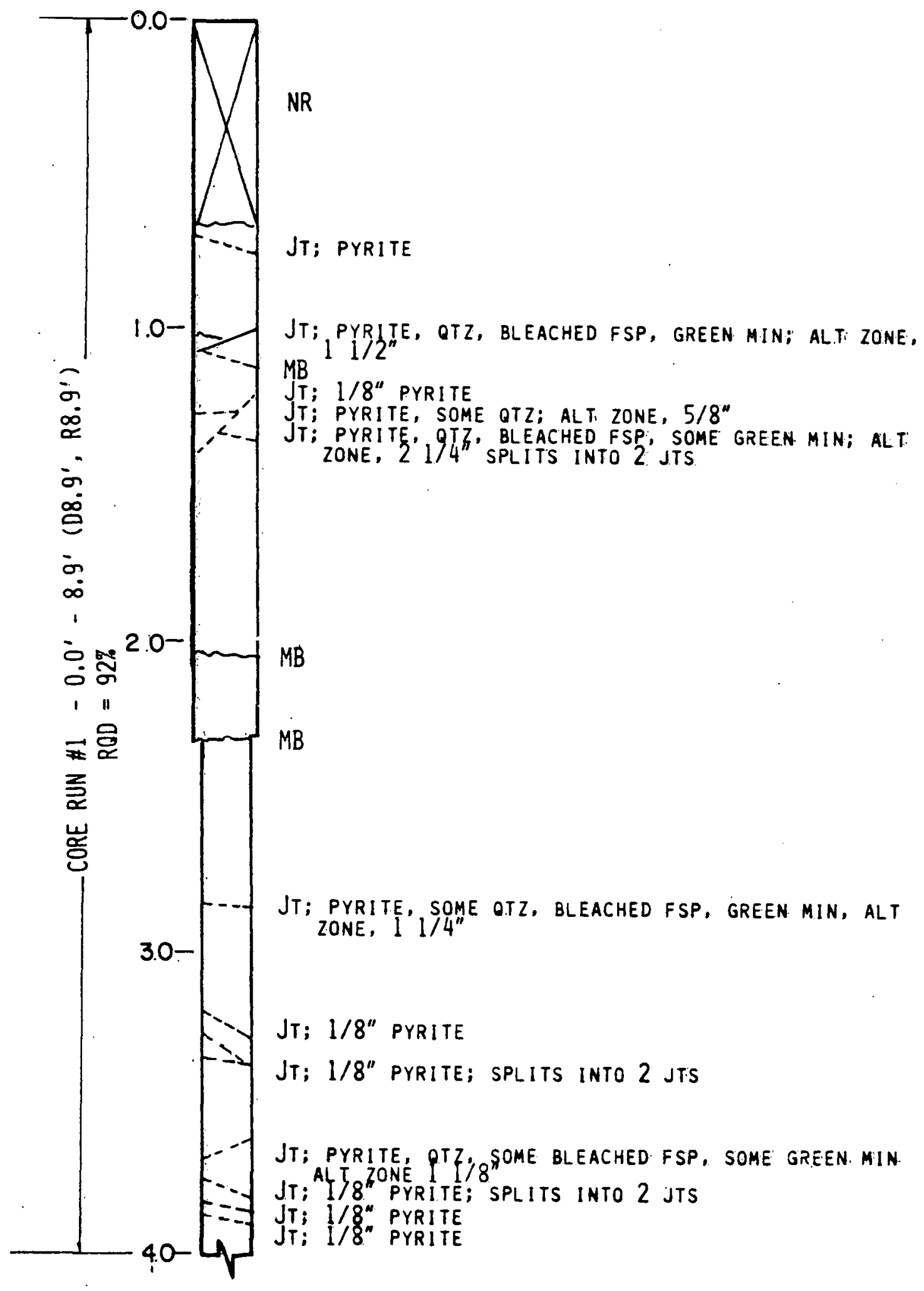

FIG. A-8a South Heater Ho.Te \#7 


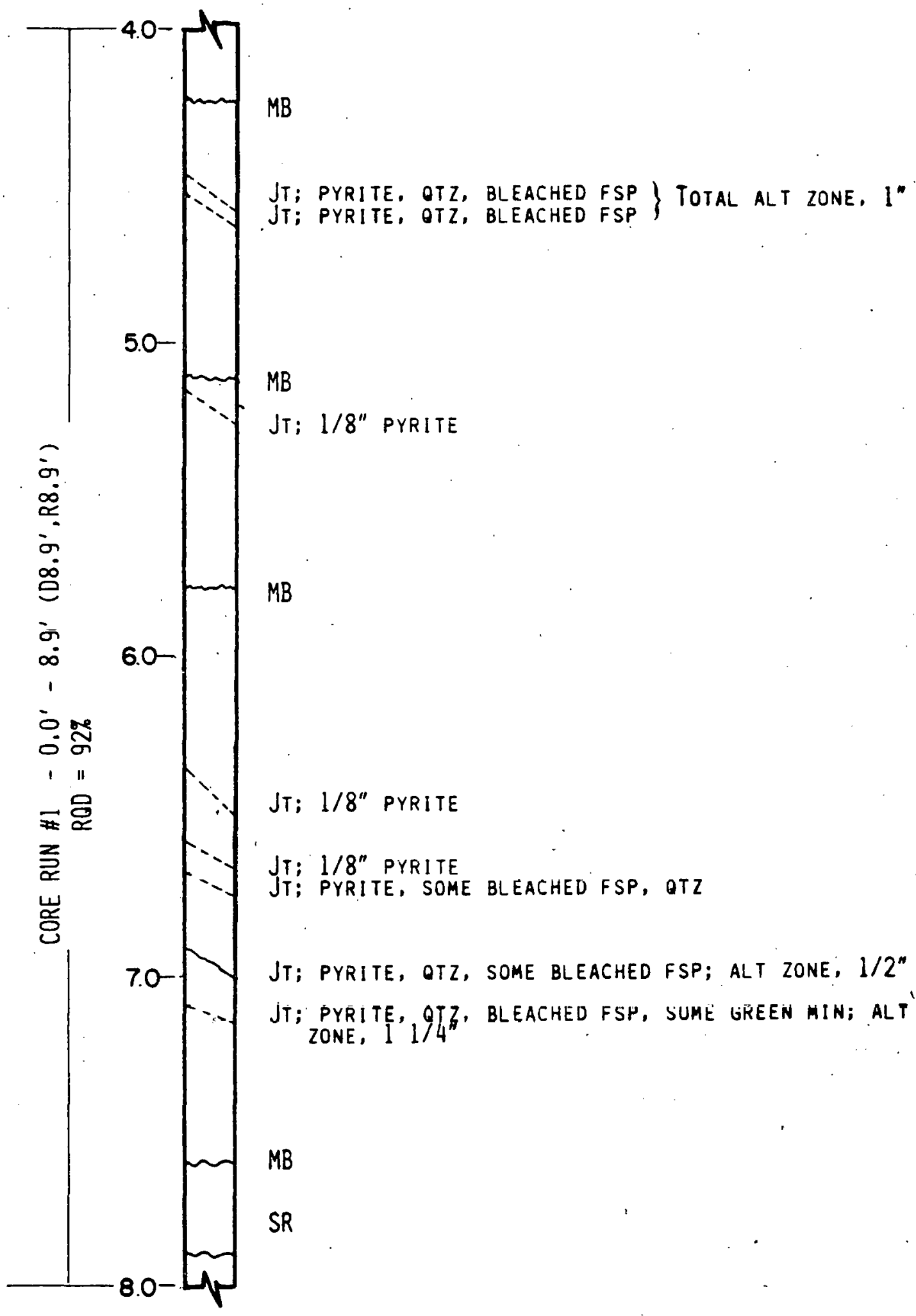

FIG. A-8b (SHH-7) 


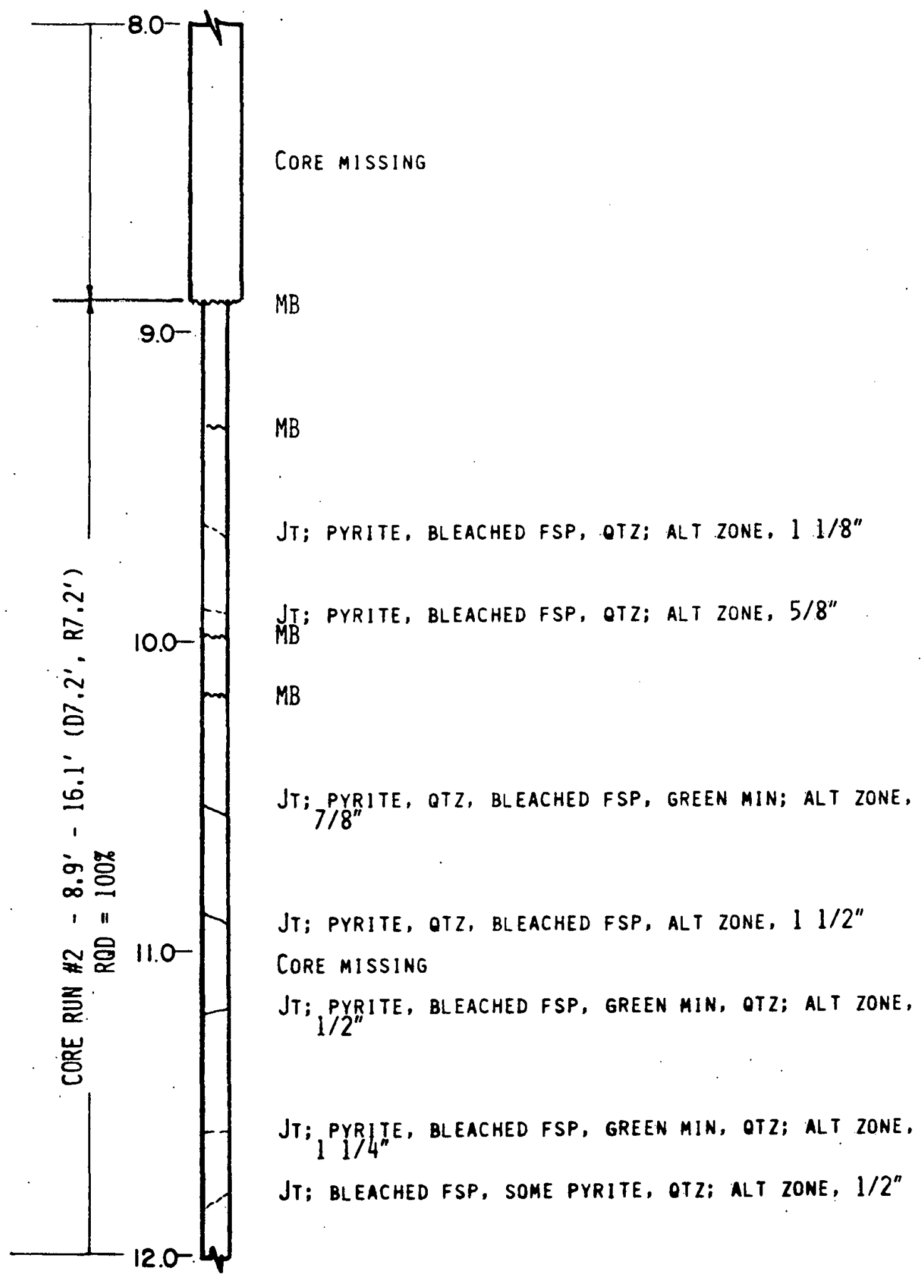

FIG. A-8c (SHH-7) 


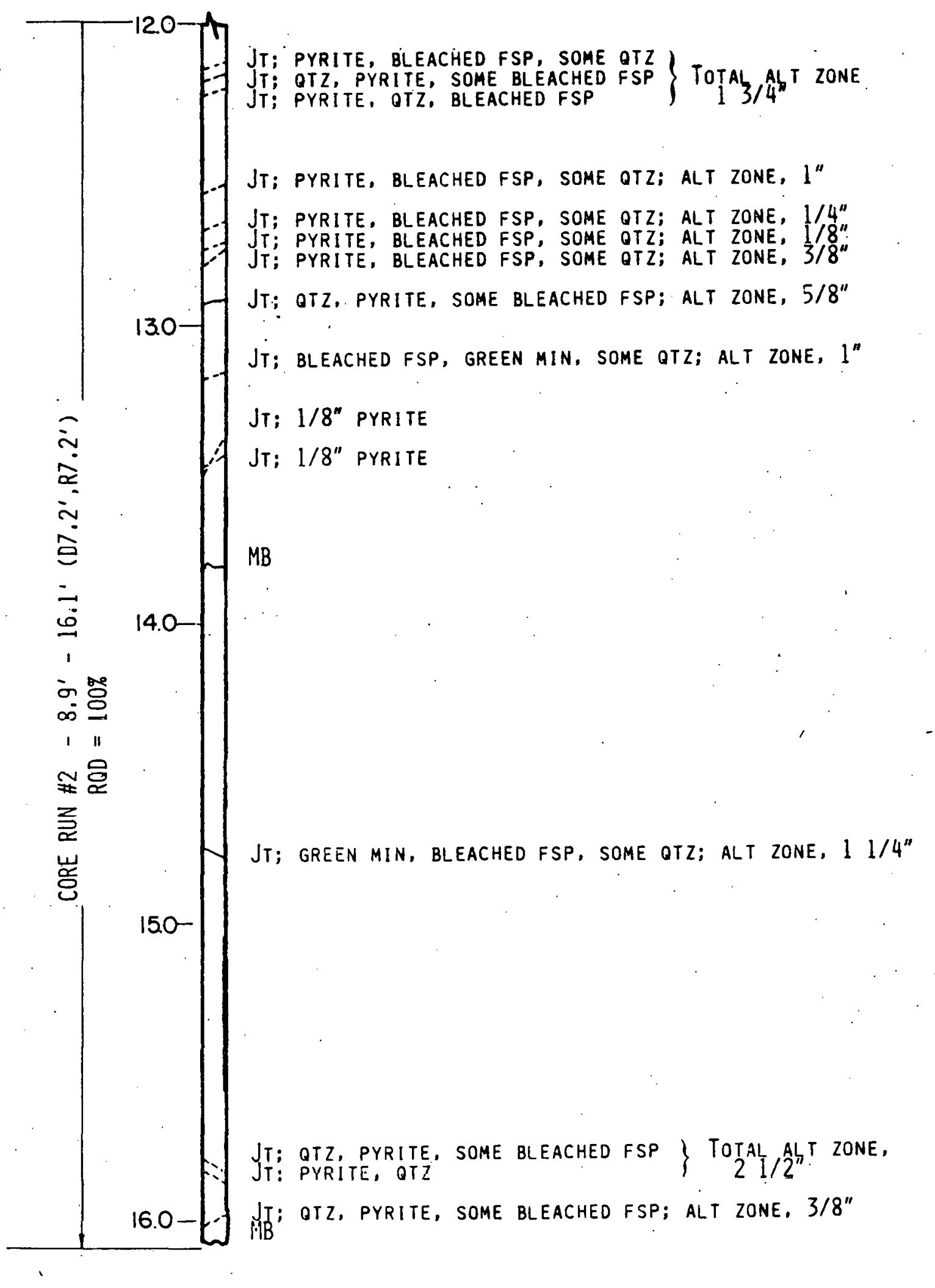

FIG. A-8d $\cdot(S H H-7)$ 


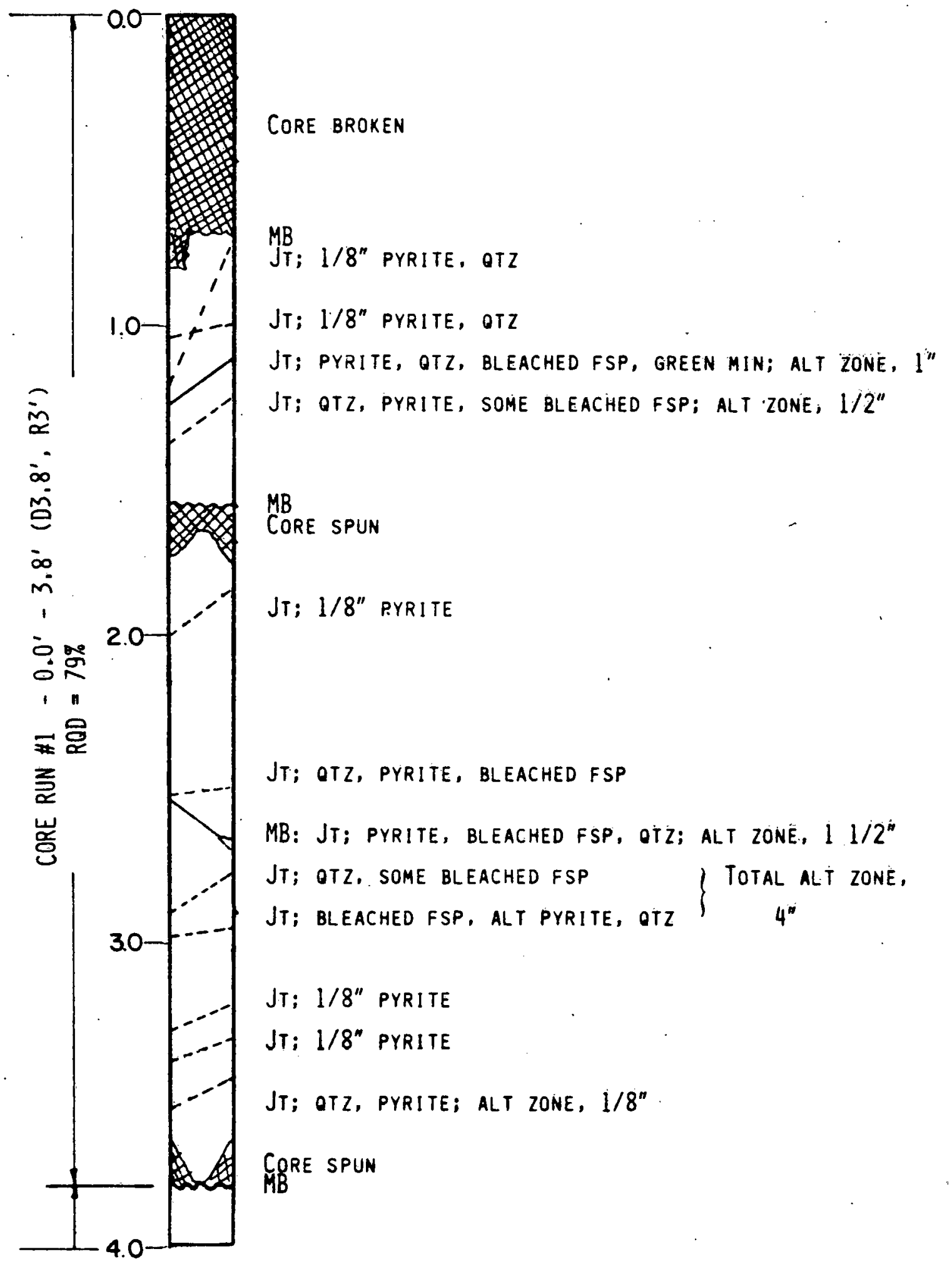

FIG. A-9a South Heàter Hole \#8 


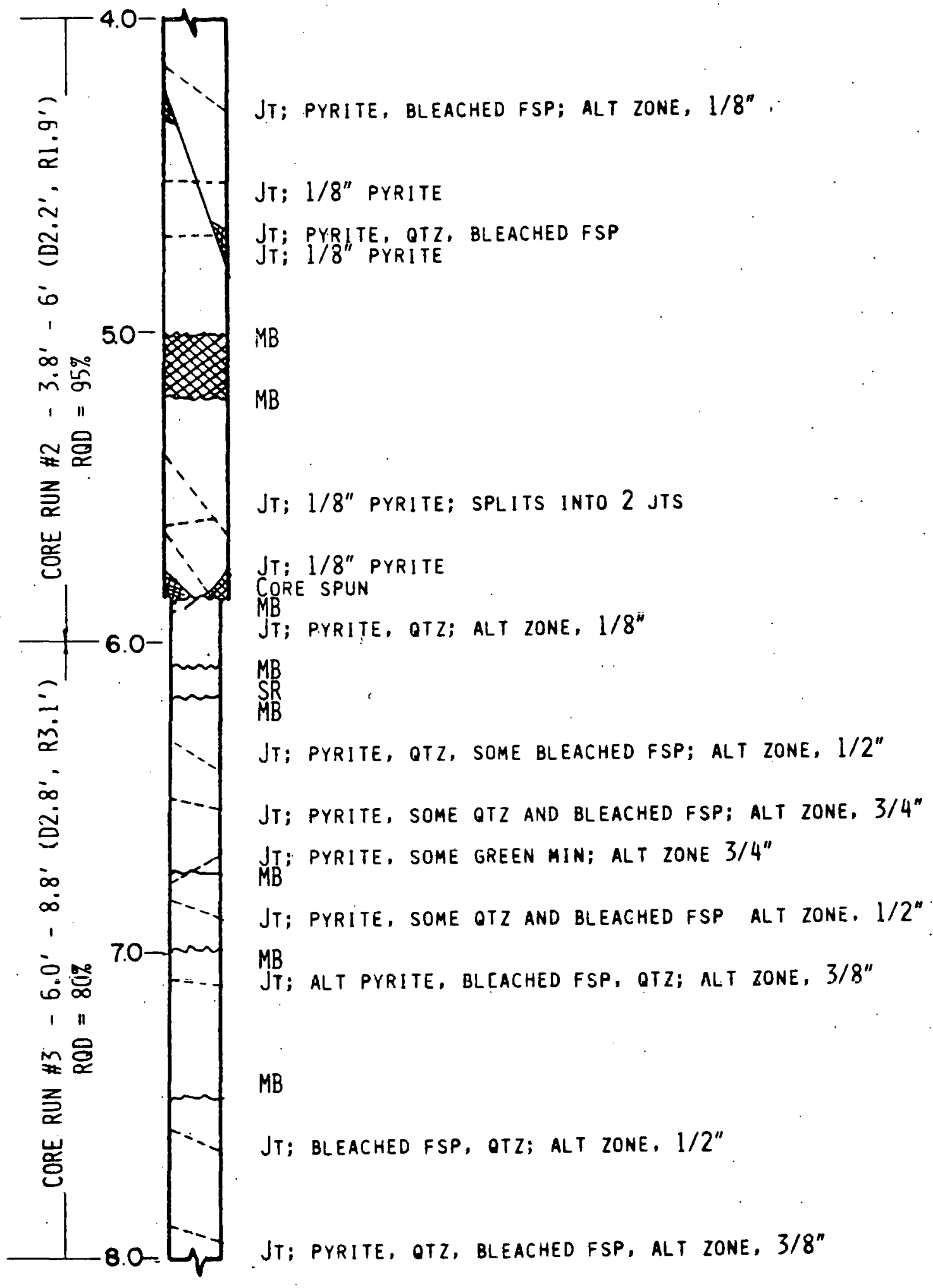

FIG. A-9b (SHH-8) 


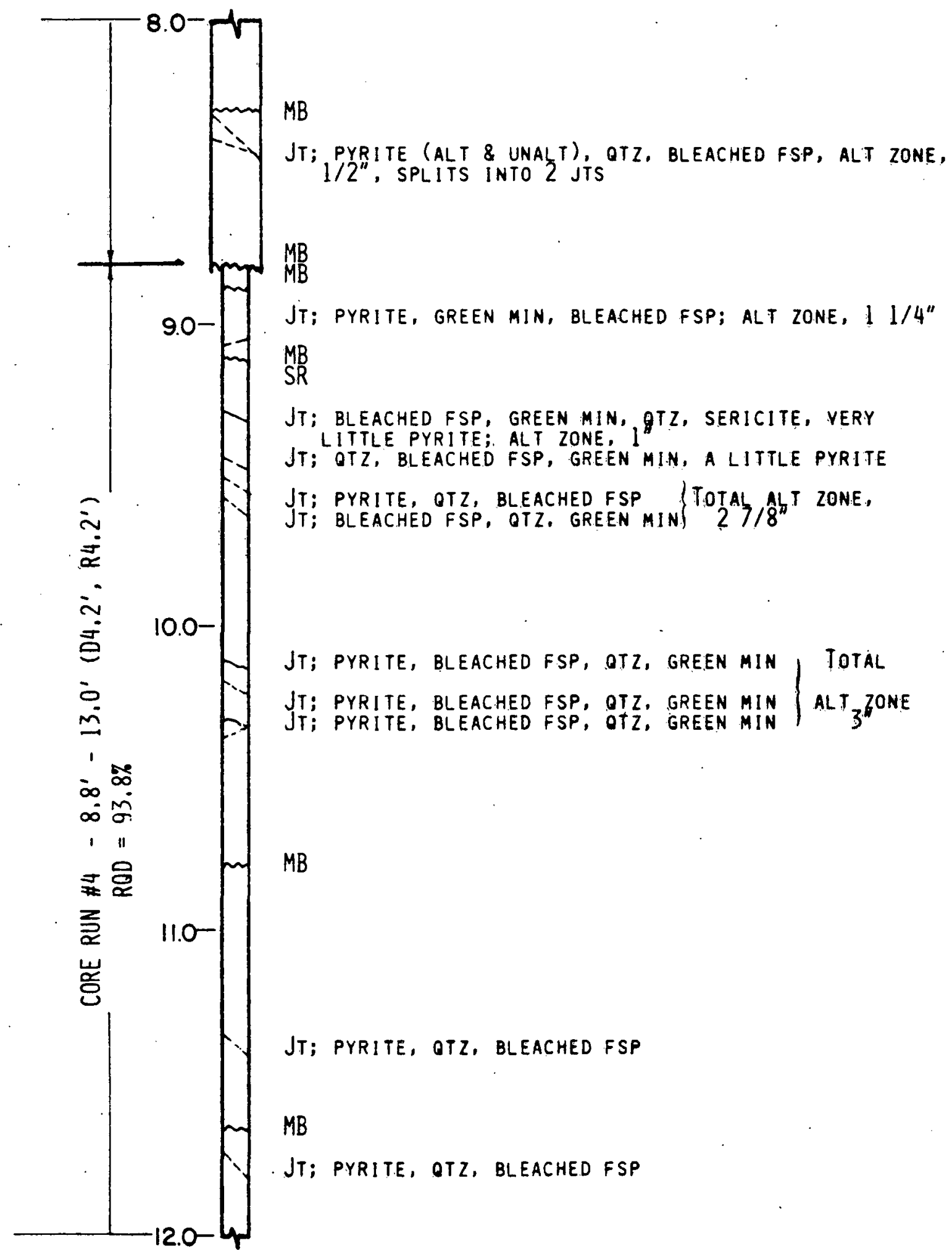

FIG. A-9c (SHH-8) 


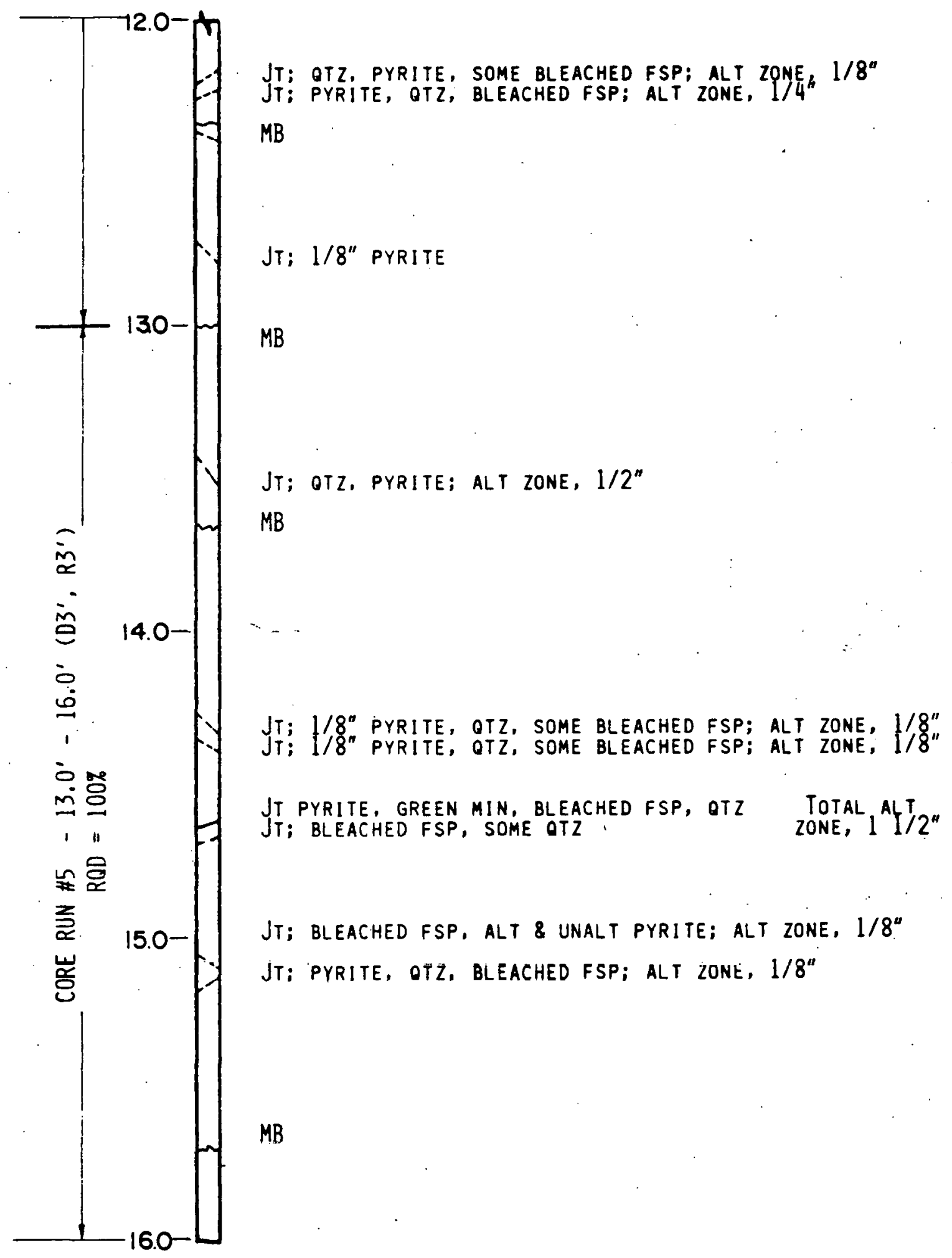

FIG. A-9d (SHH-8) 


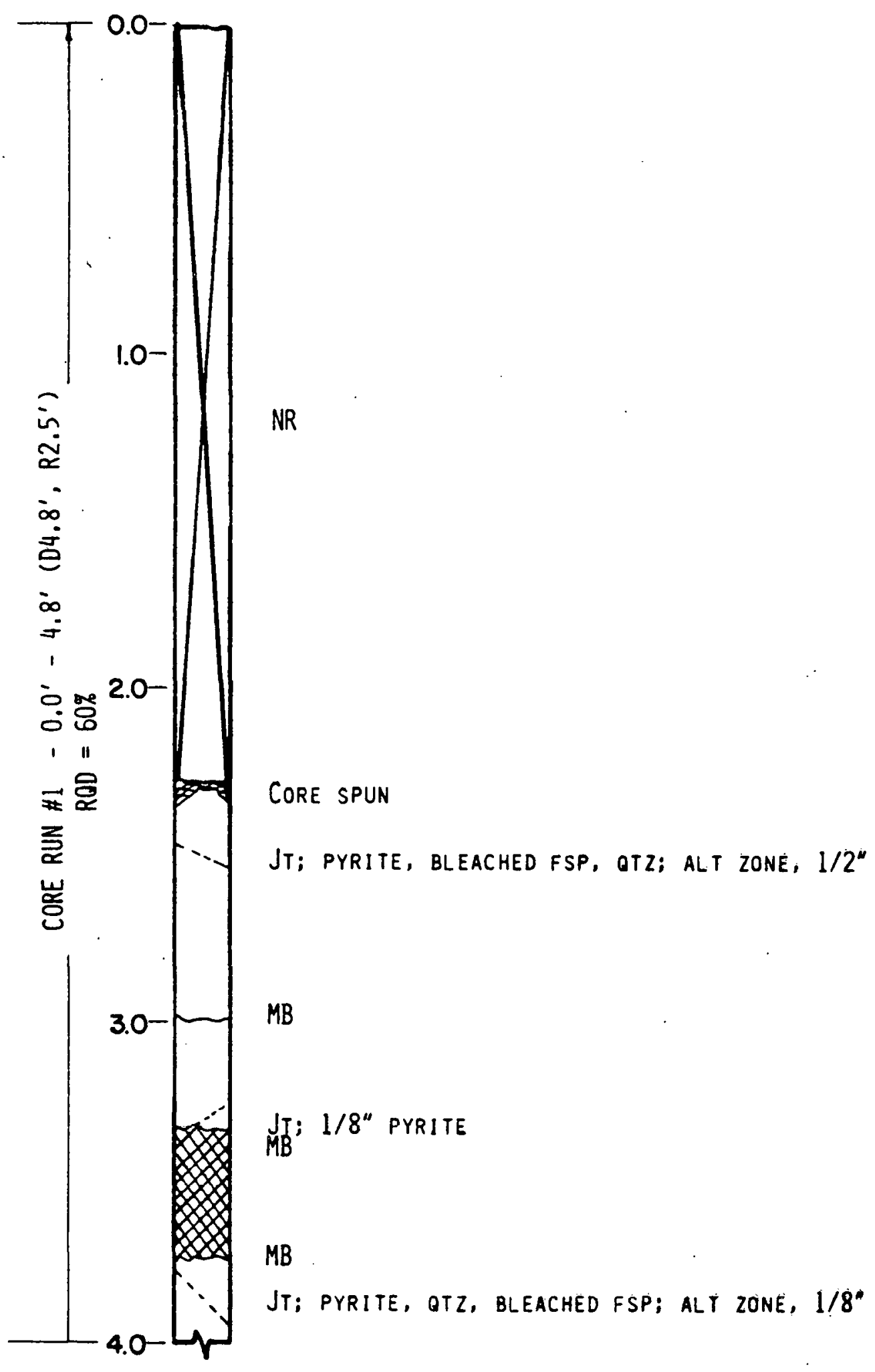

FIG. A-10a South Heater Hole \#9 


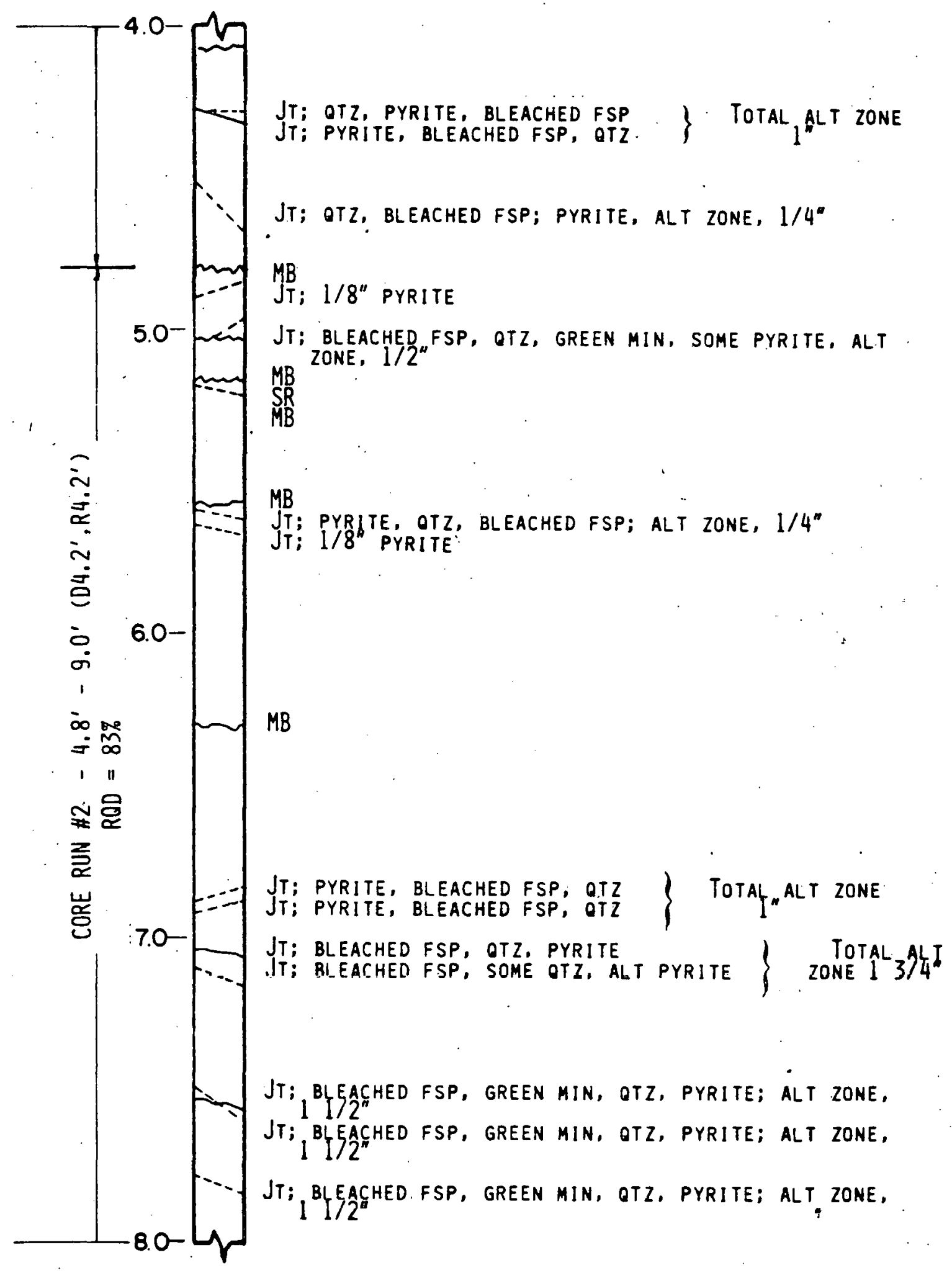

FIG. $1-10 b \quad(5 H H-3)$ 


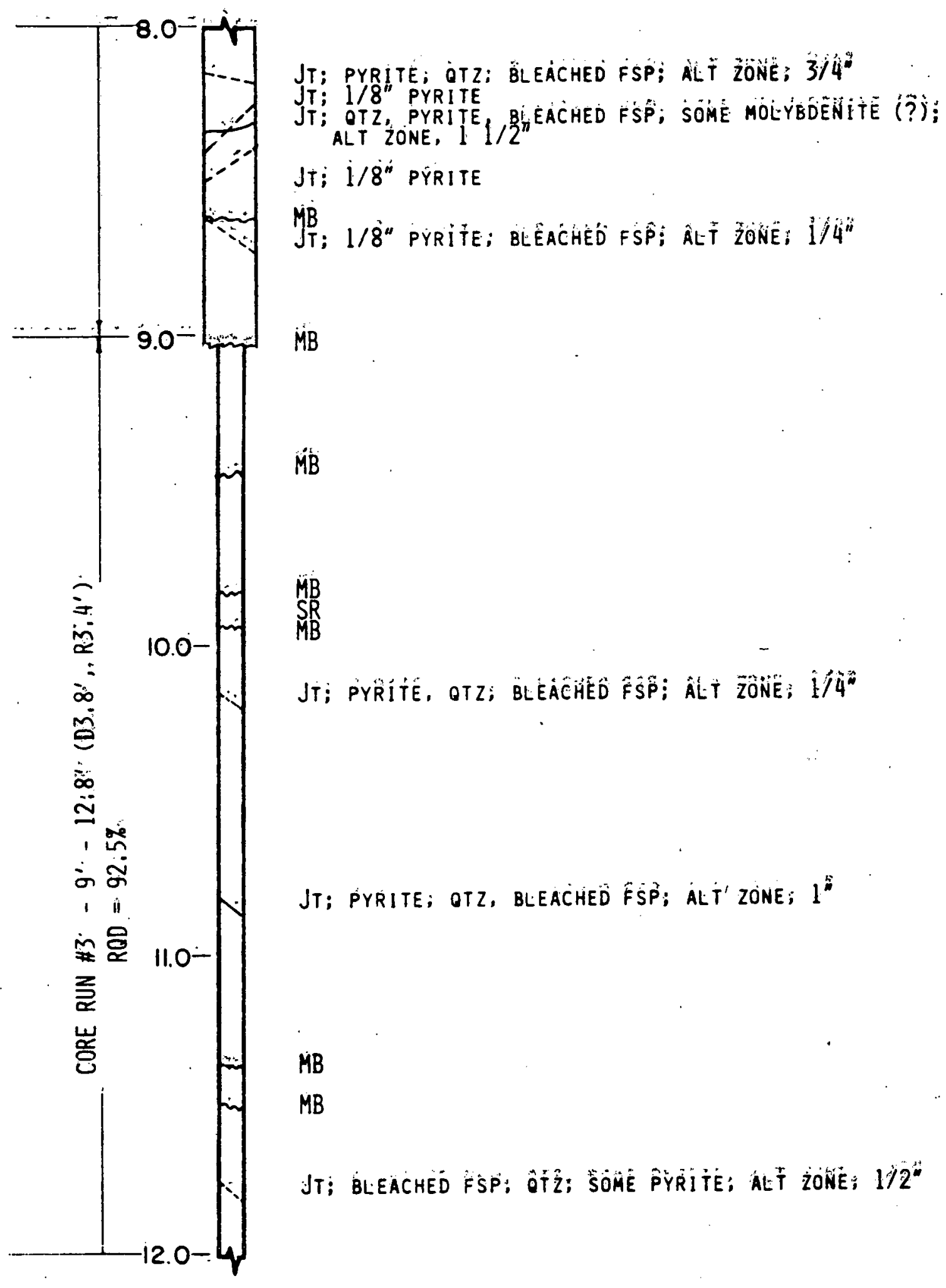

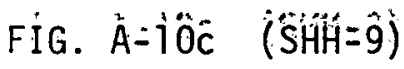




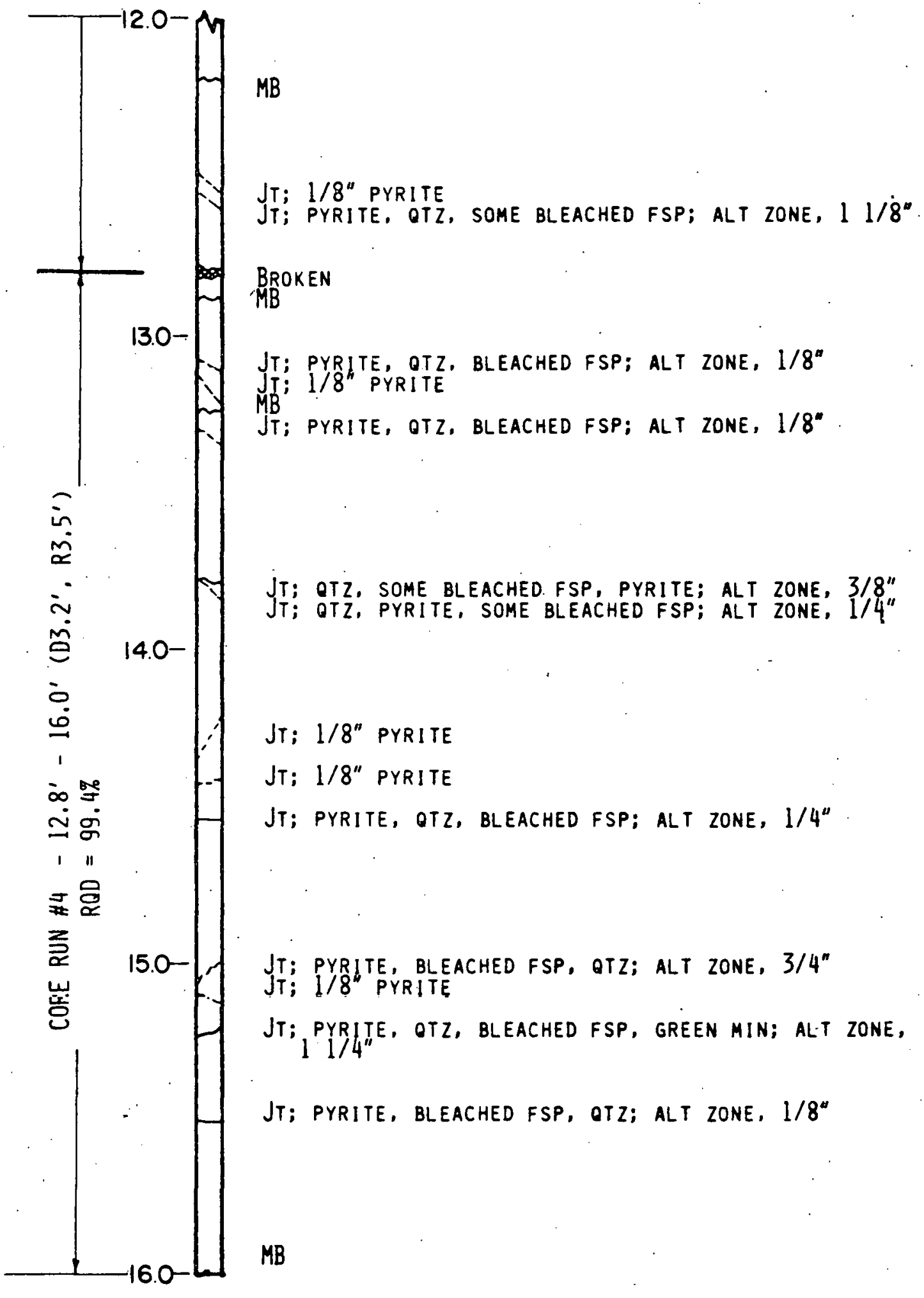

FIG. A-10d (SHH-9) 


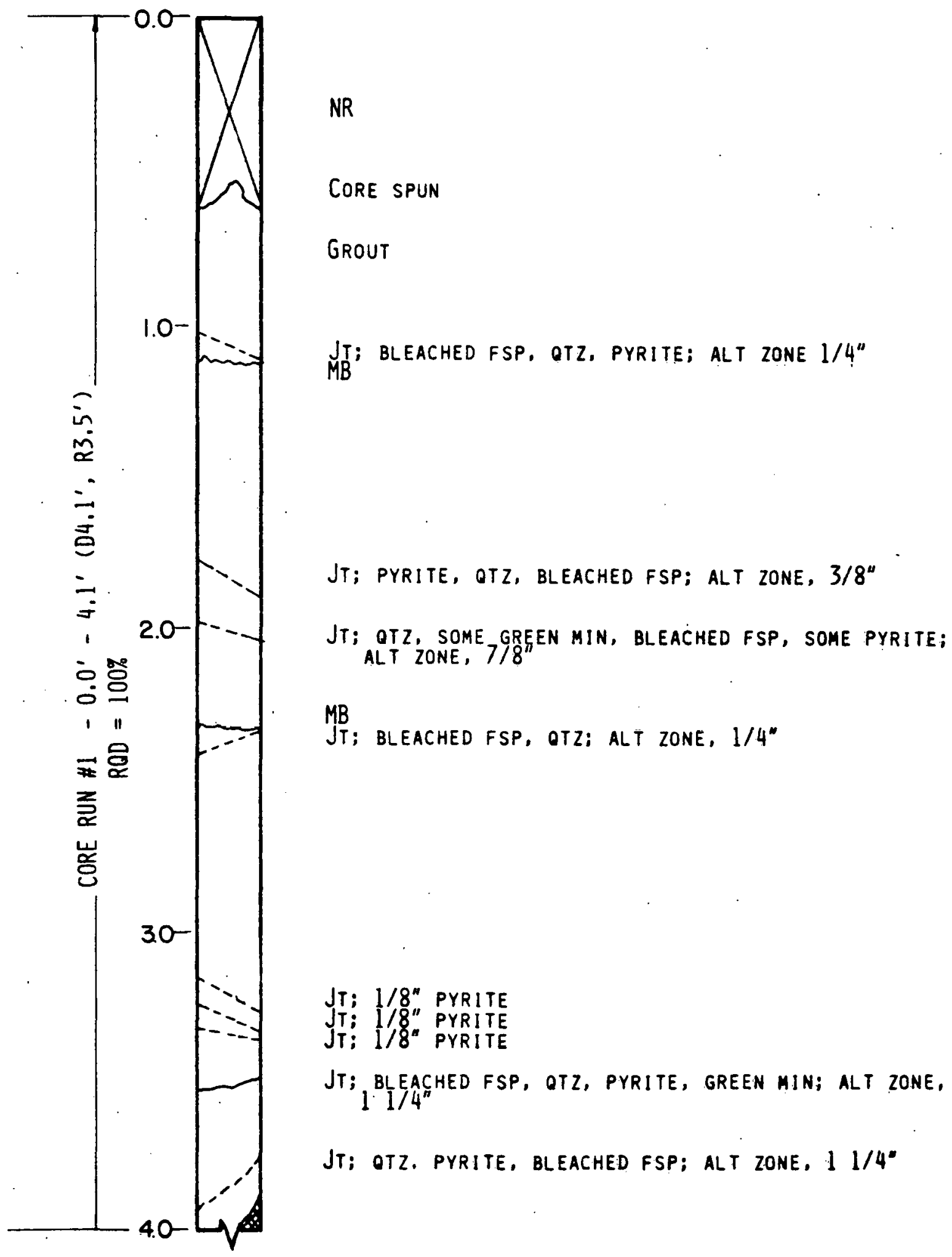

FIG. A-lla South Heater Hole \#10 


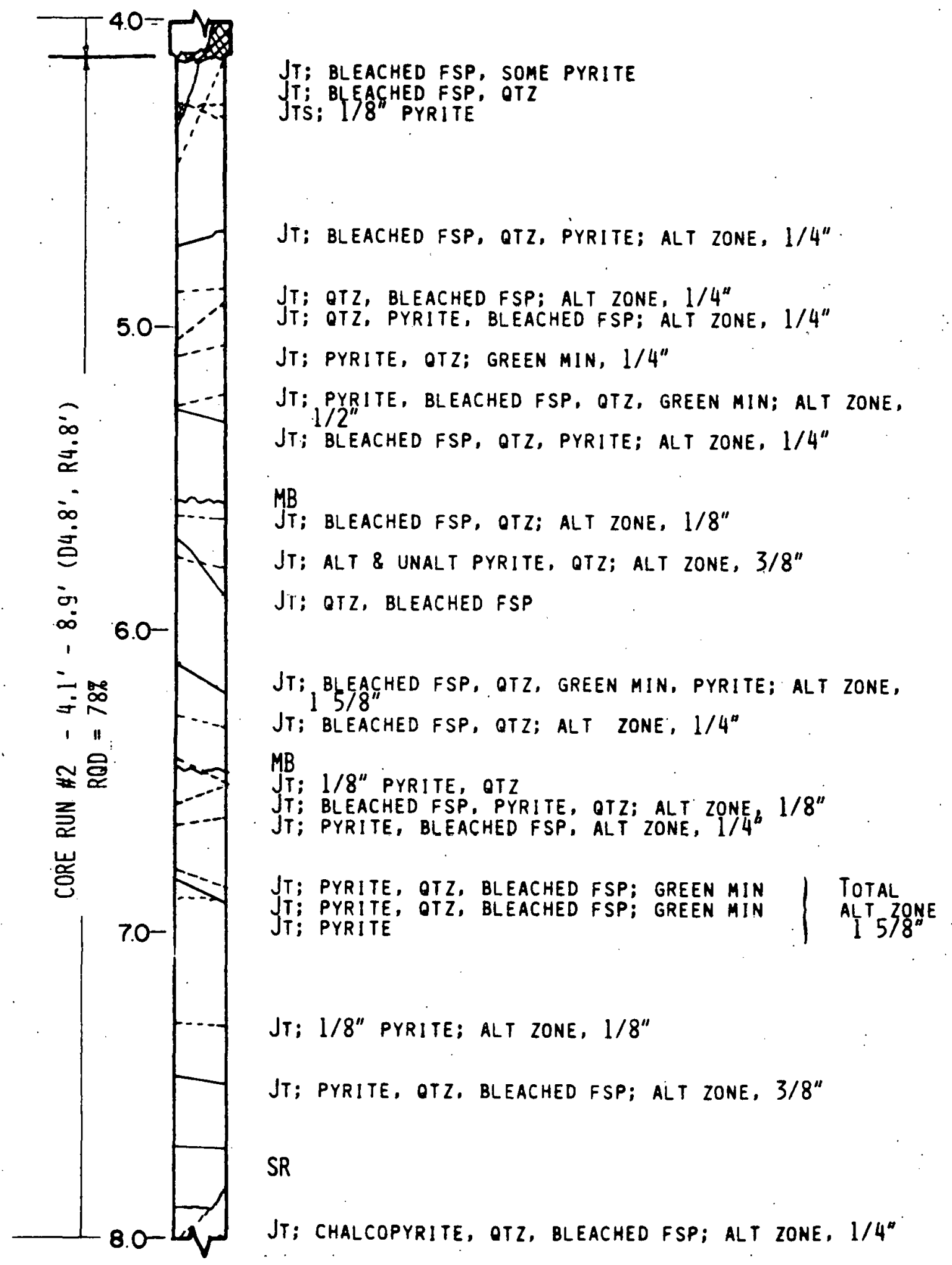

FIG. A-11b (SHH-10) 


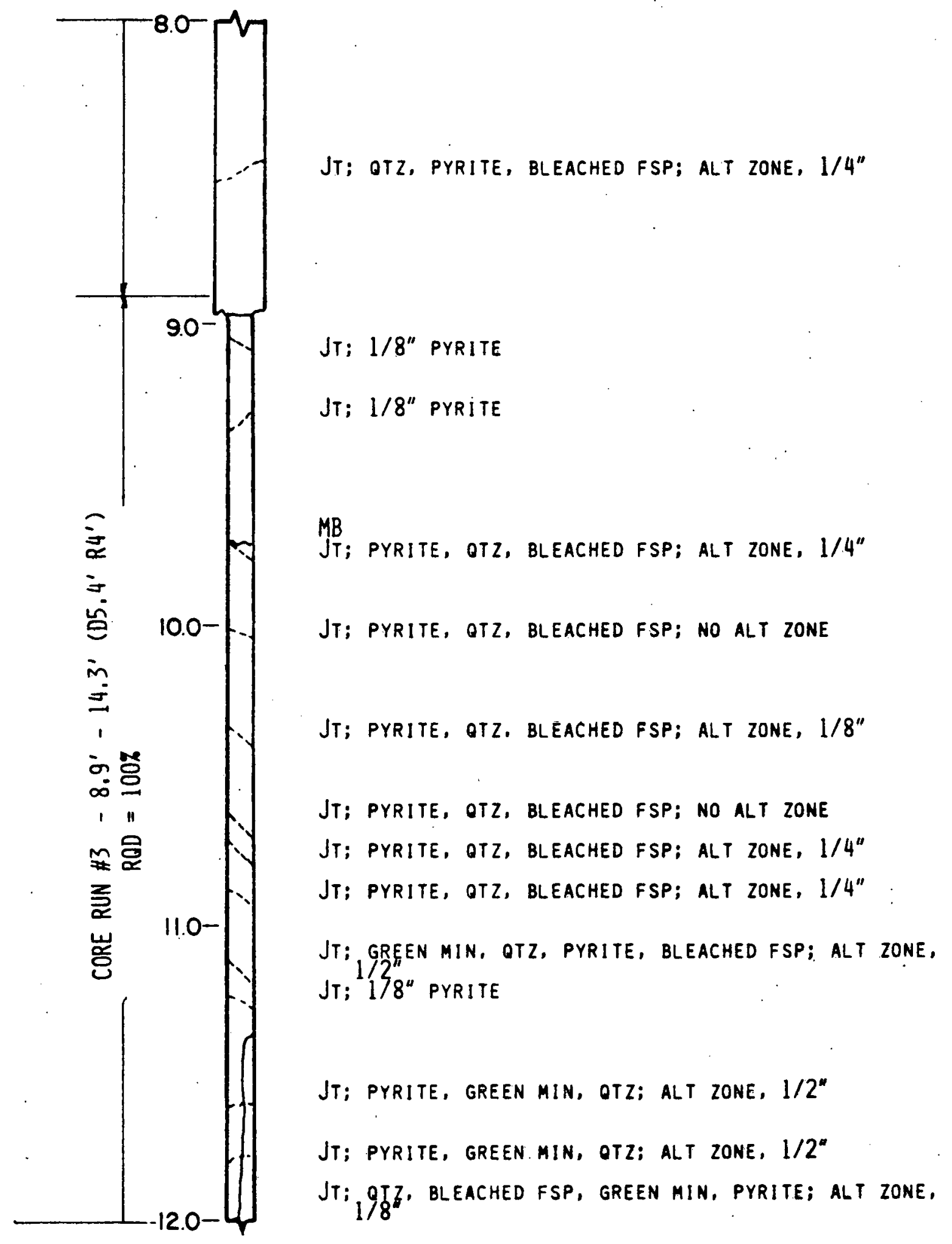

FIG. A-11C (SHH-10) 


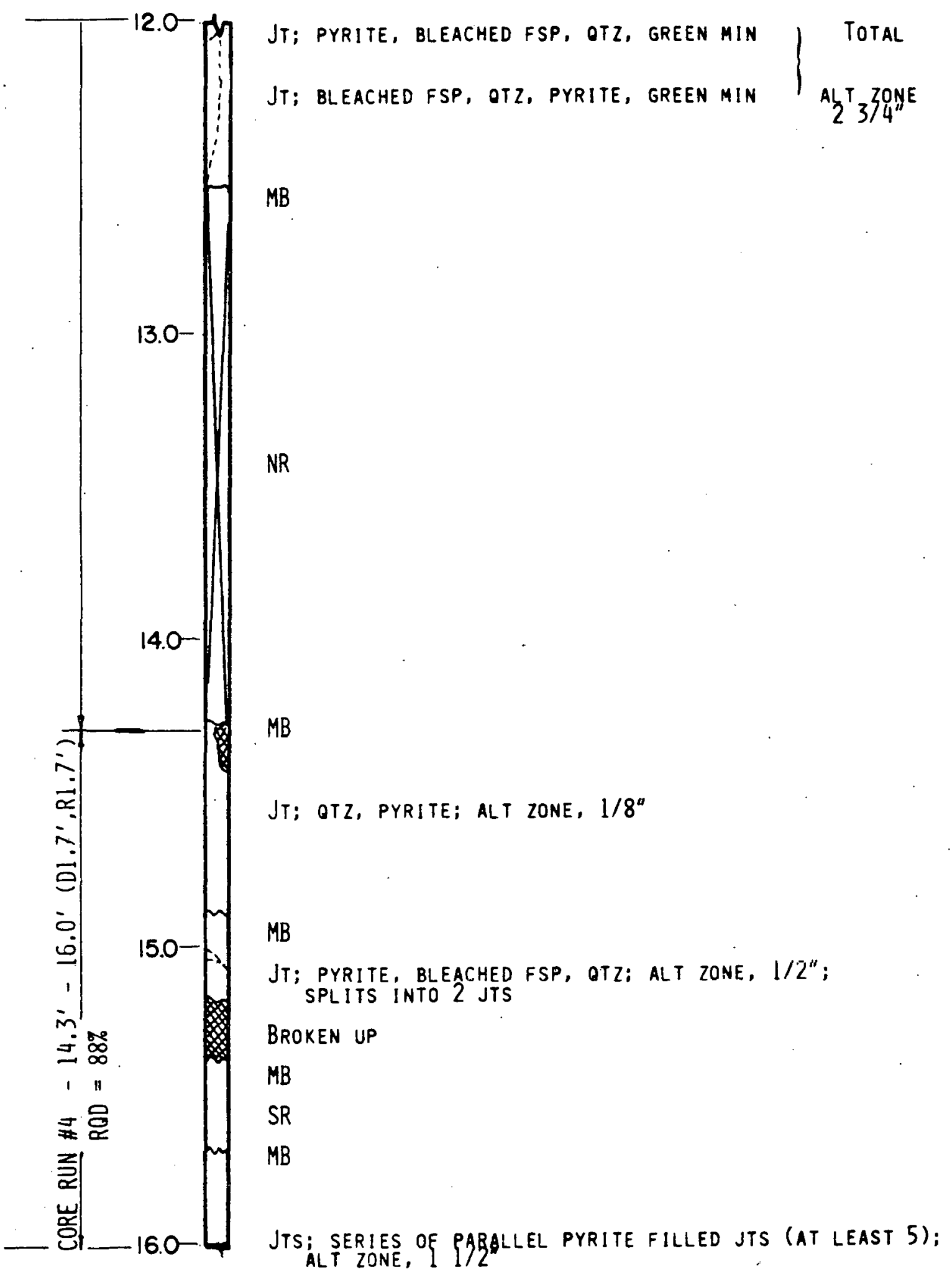

FIG. A-11d (SHH-10) 


\section{PAGES B1 to B2 WERE INTENTIONALLY LEFT BLANK}




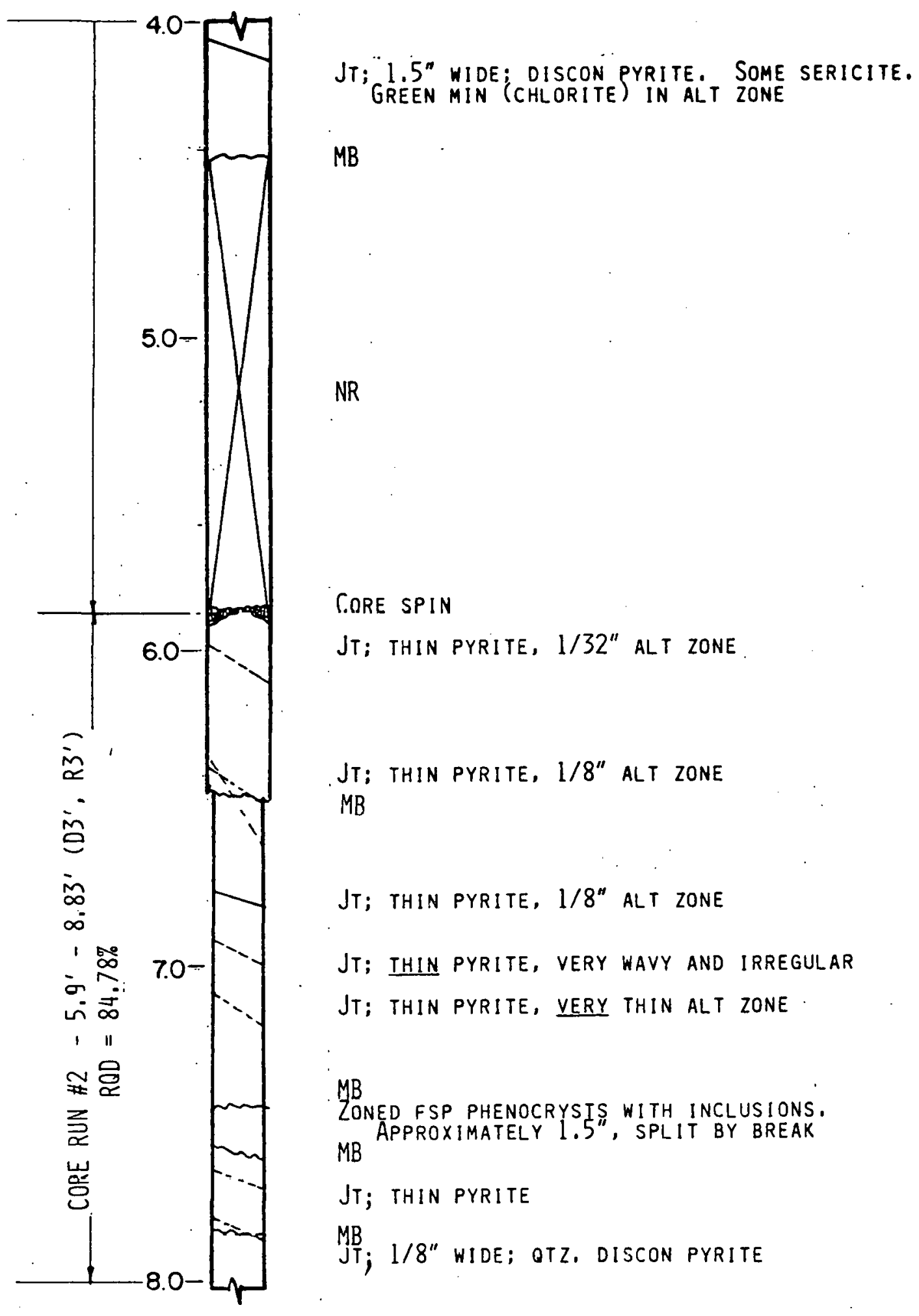

FIG. B-7b (NHH-1) 


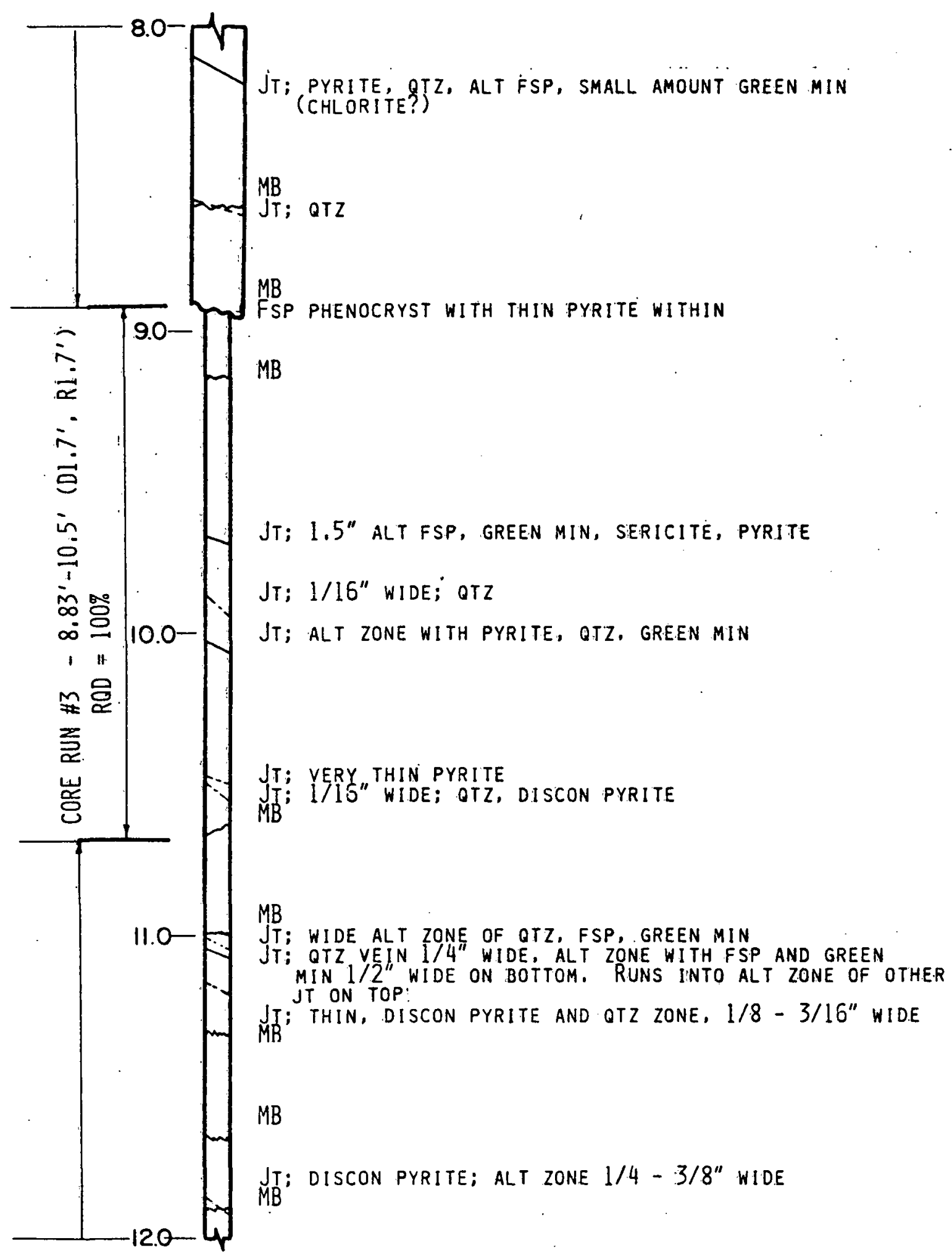

FIG. B-1C (NHH-1) 


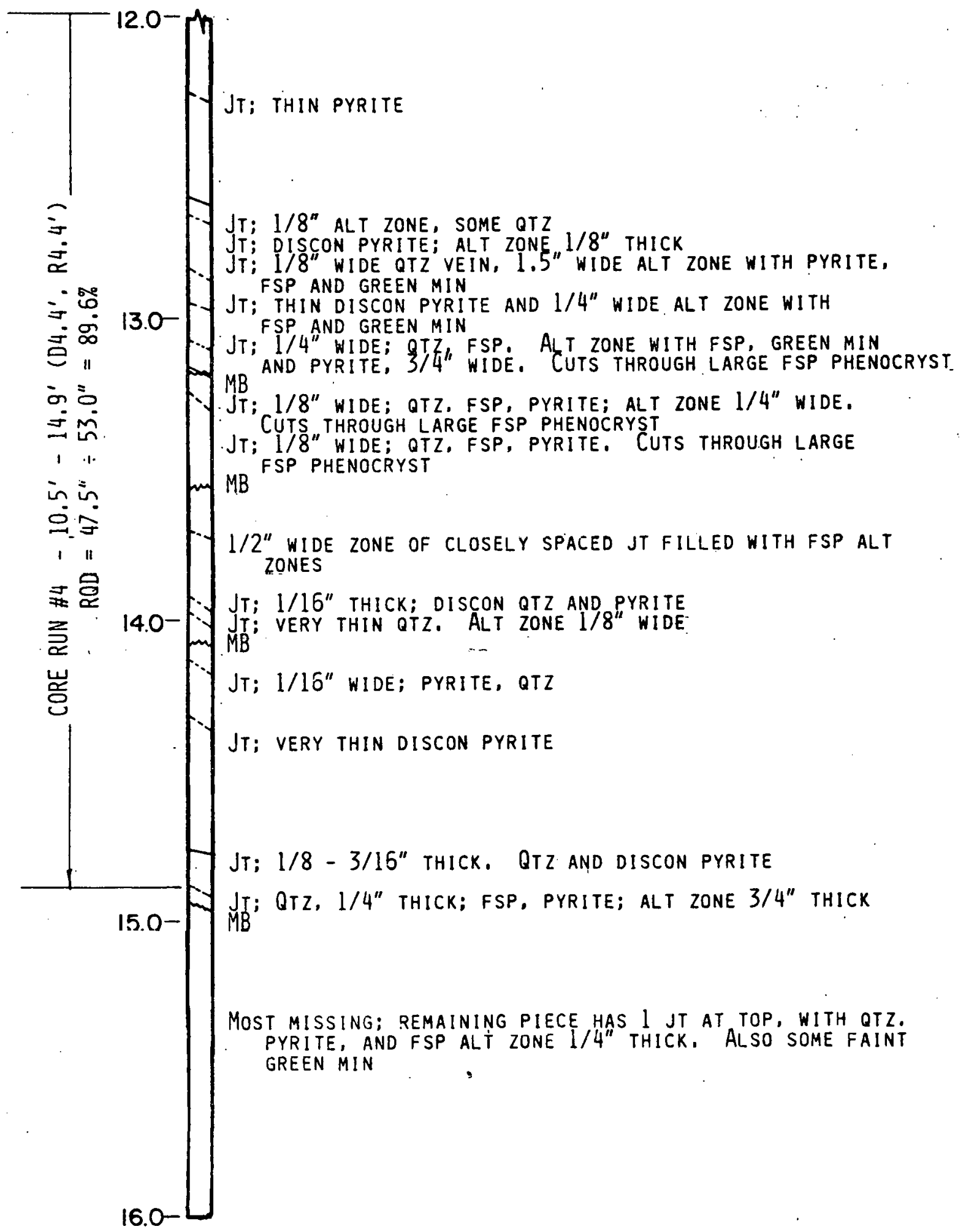

FIG. B-Id (NHH-l) 


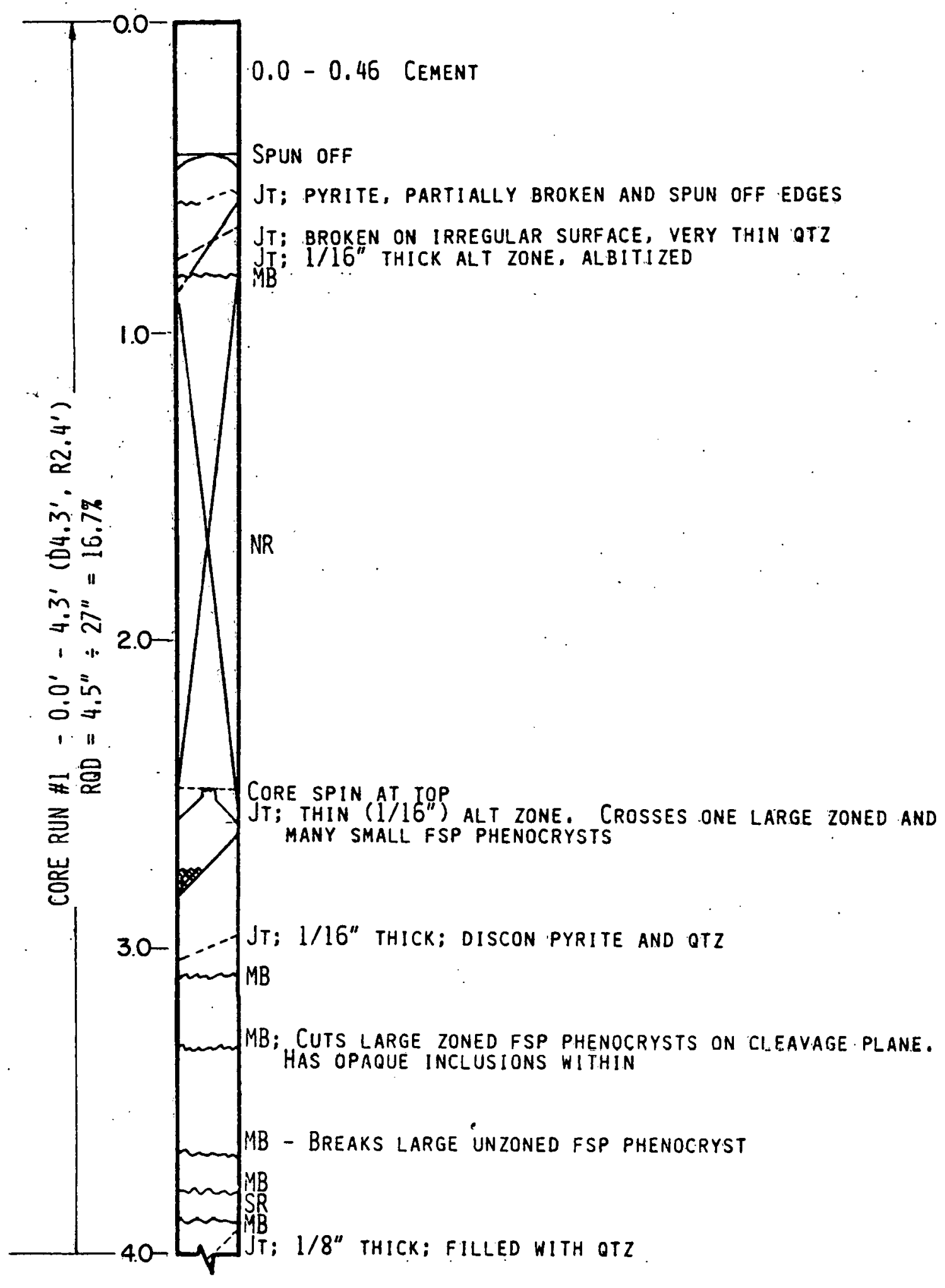

FIG. B-2a North Heater Hole \#2 


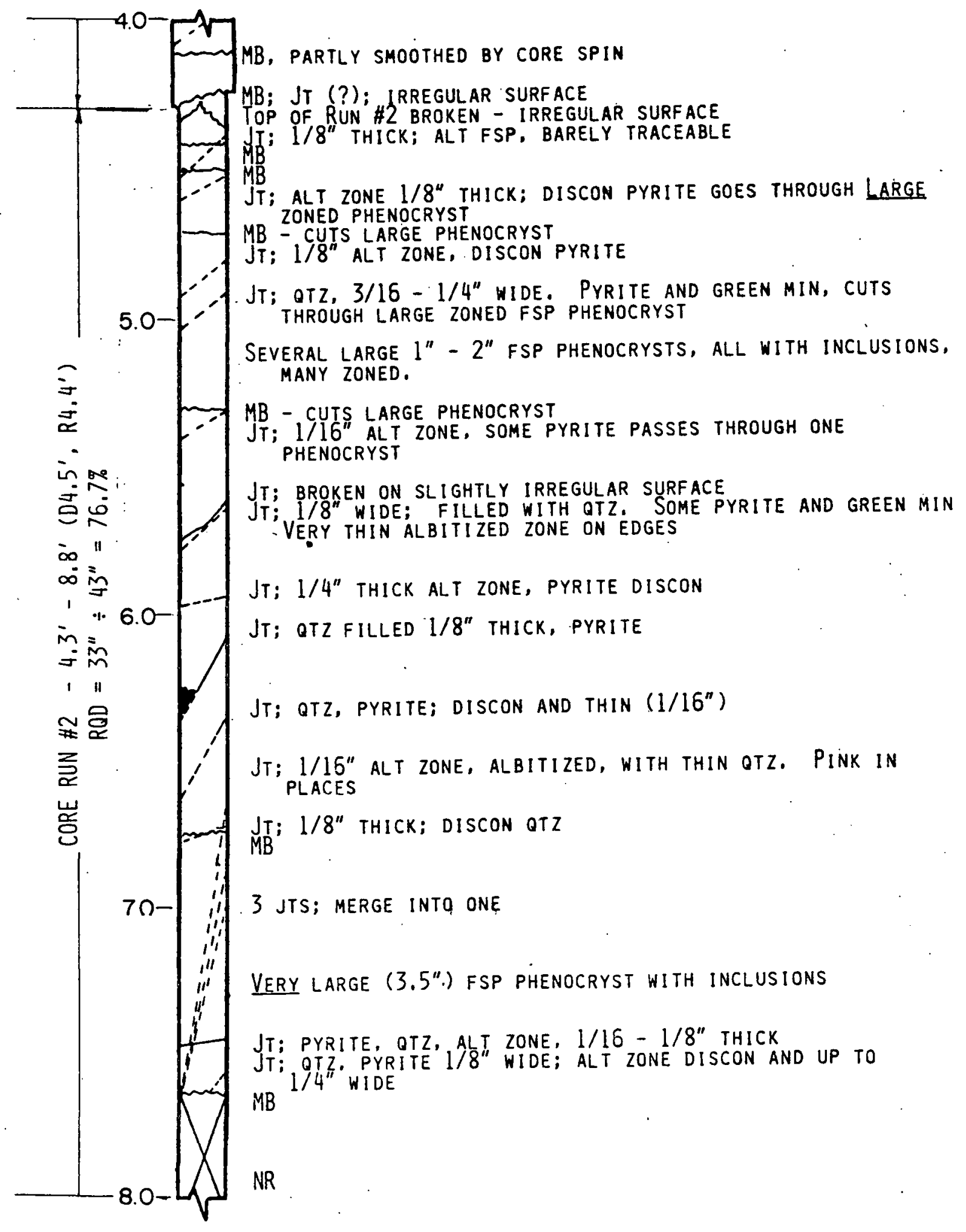

FIG. B-2b (NHH-2) 


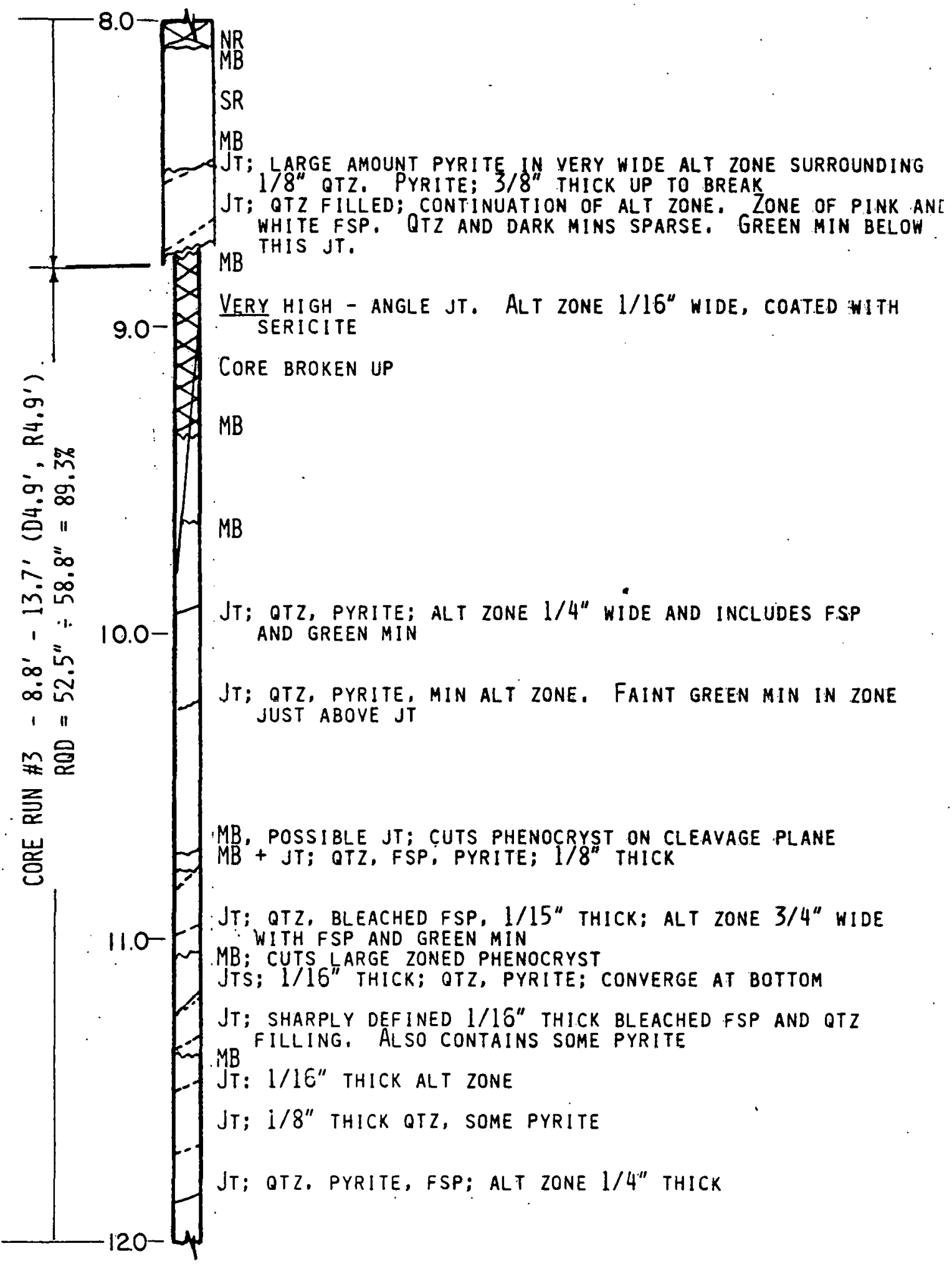

FIG. B-2C (NHH-2) 


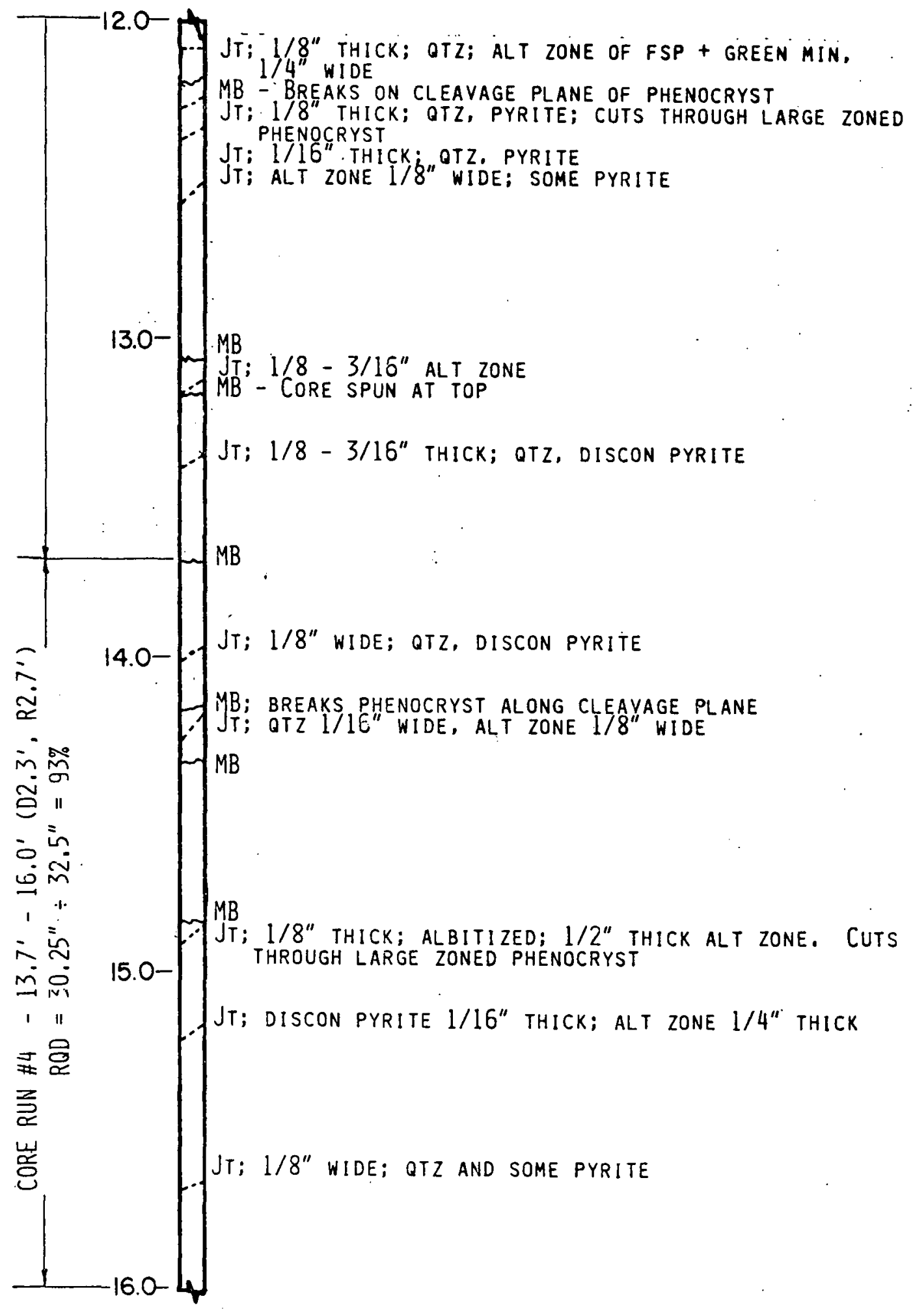

FIG. B-2d (NHH-2) 


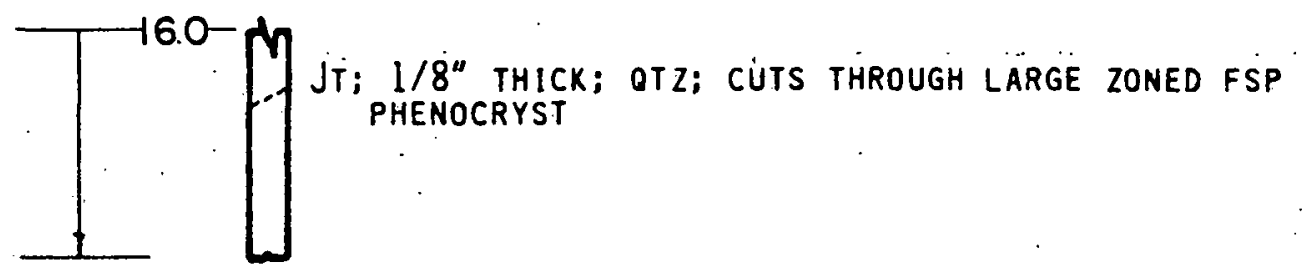

FIG. B-2e (NHH-2)

- B10 - 


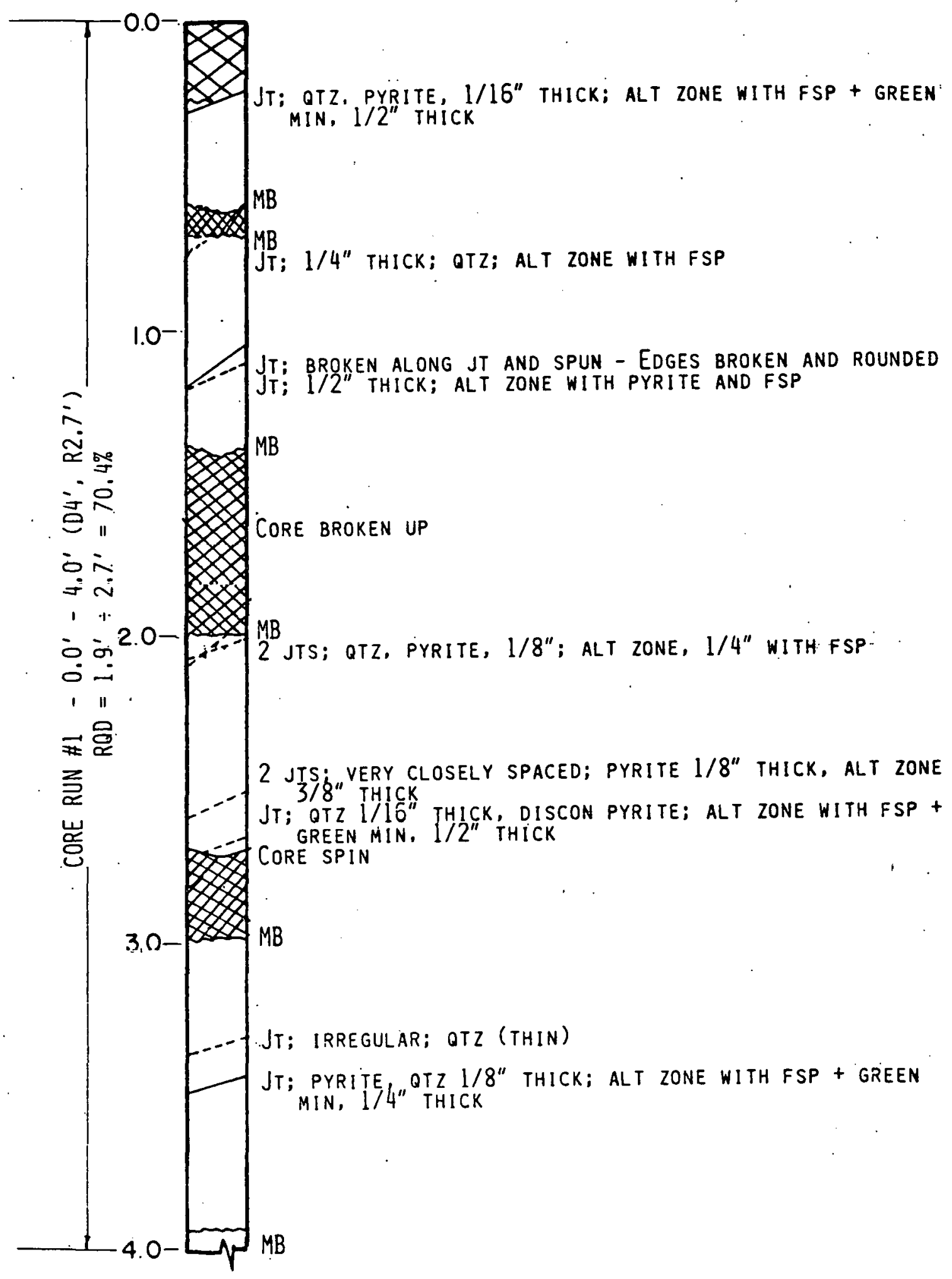

FIG. B-3a North Heater Hole \#3 


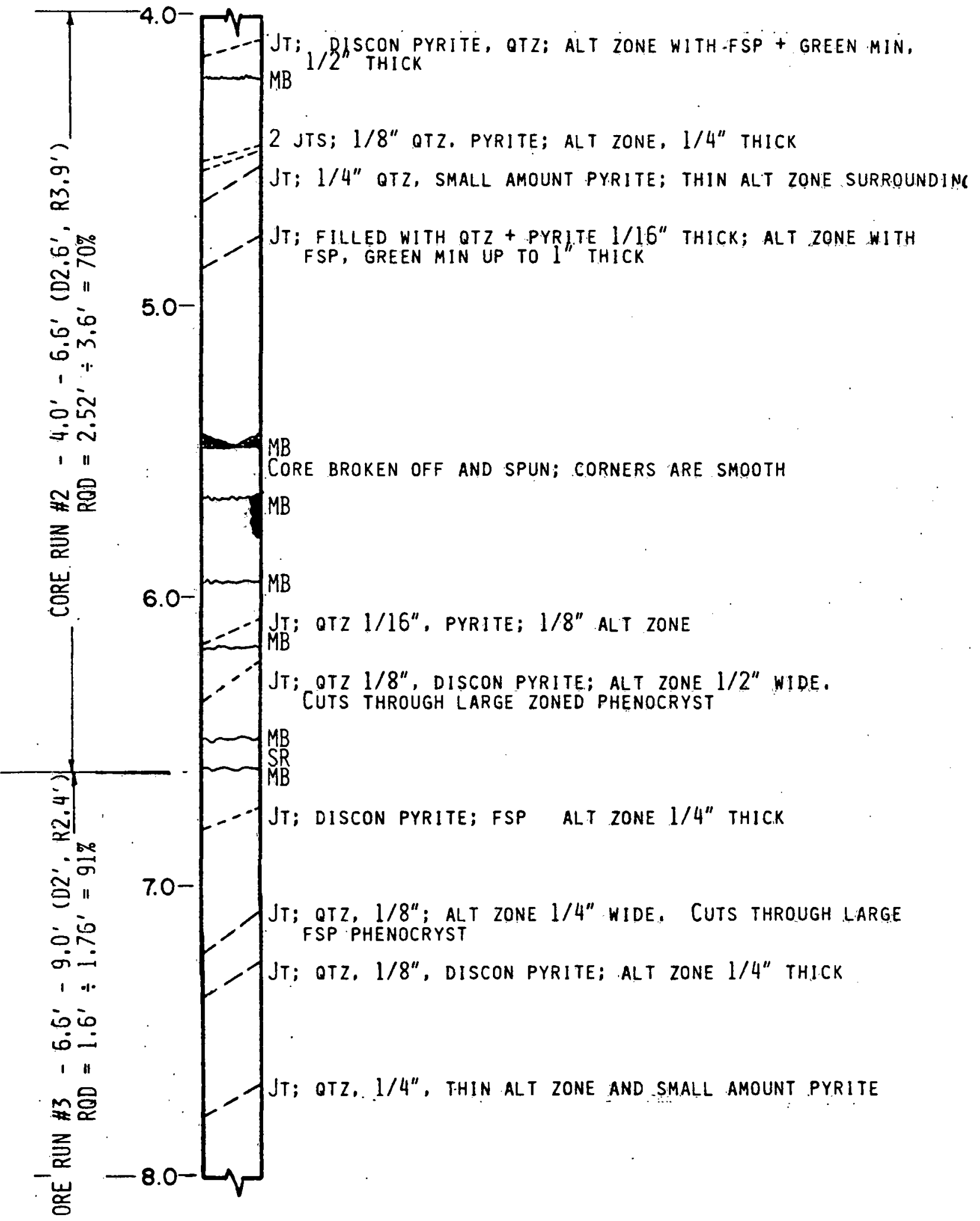

FIG. B-3b (NHH-3) 


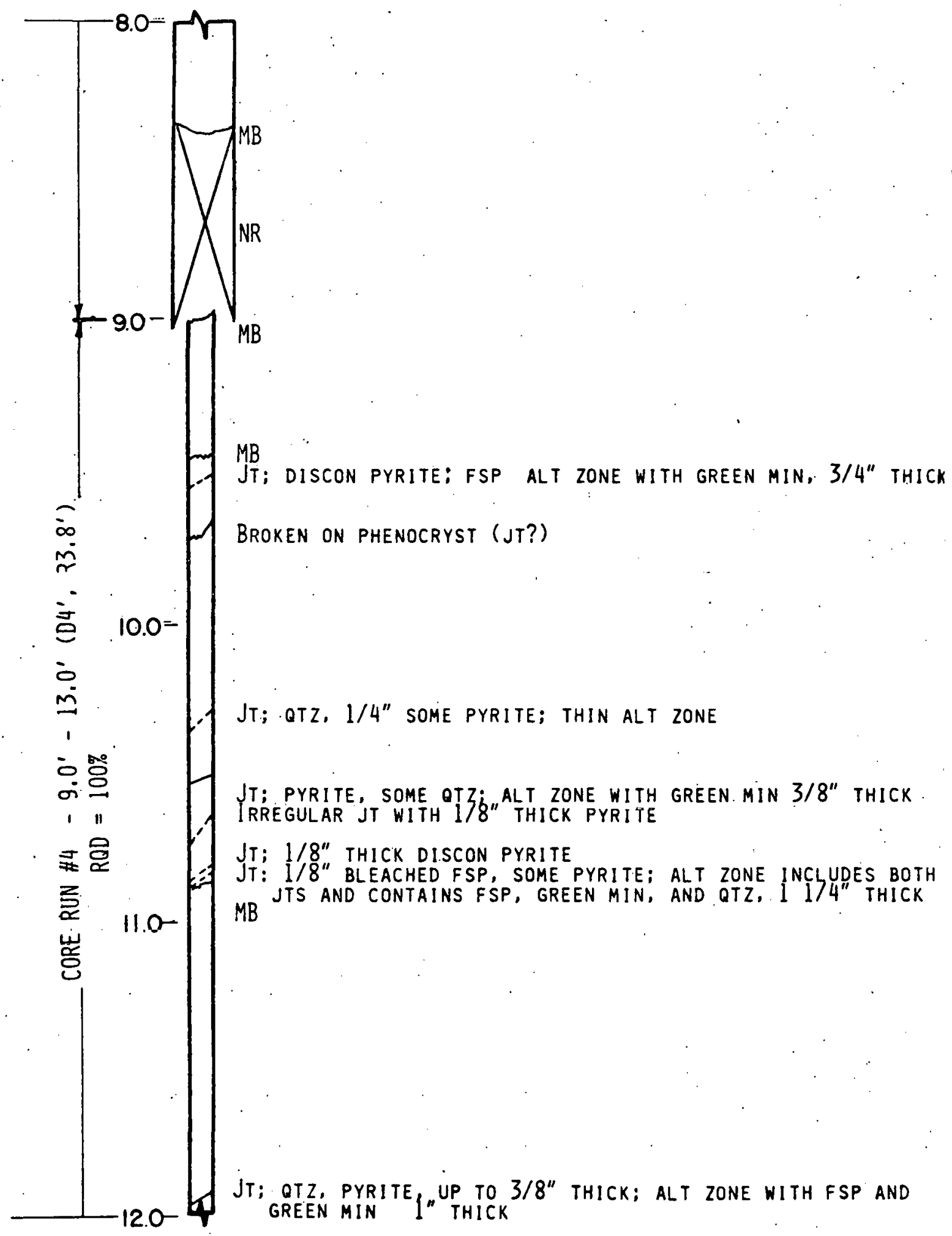

FIG. B-3c (NHH-3) 


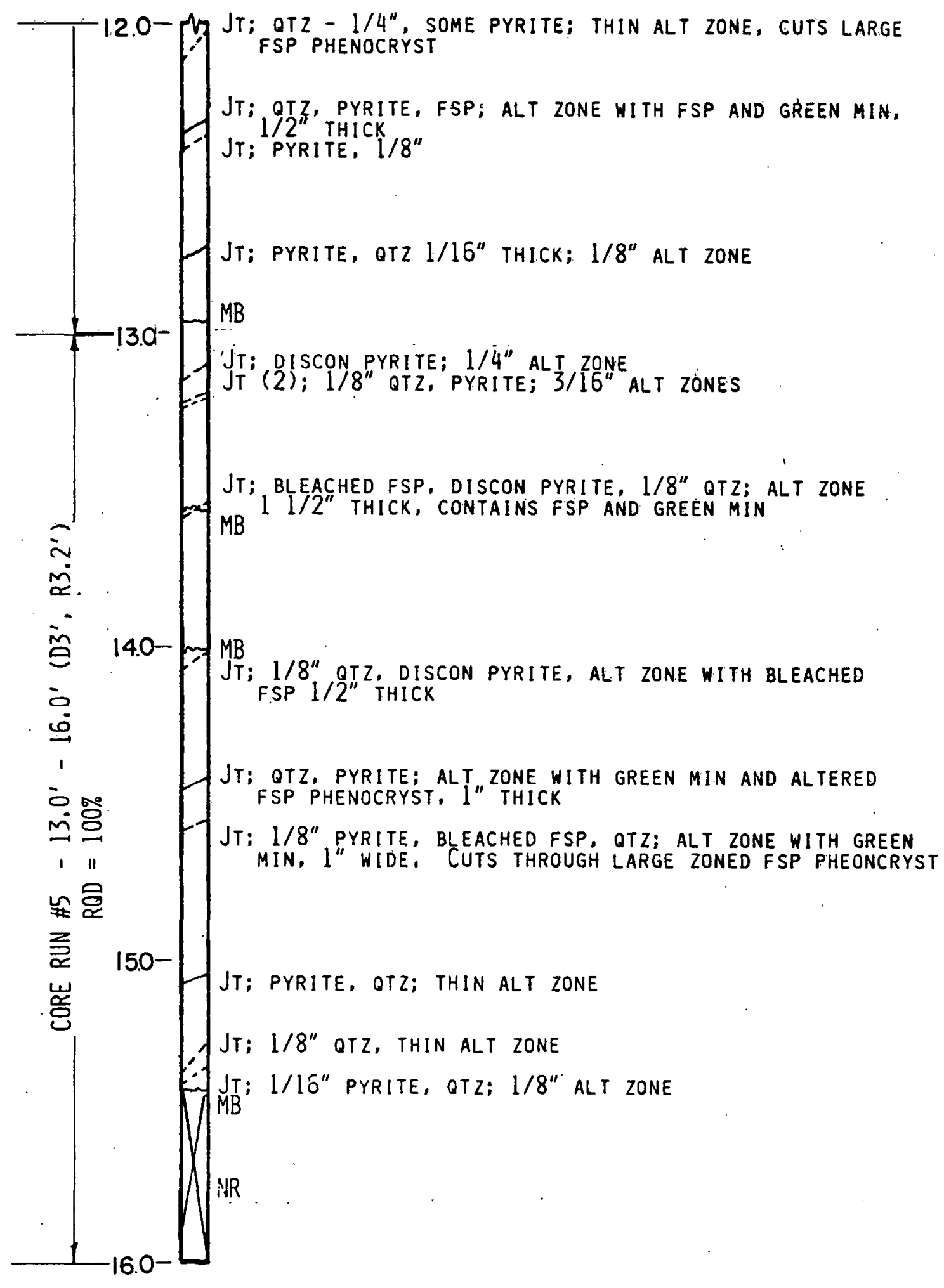

FIG. B-3d (NHH-3) 


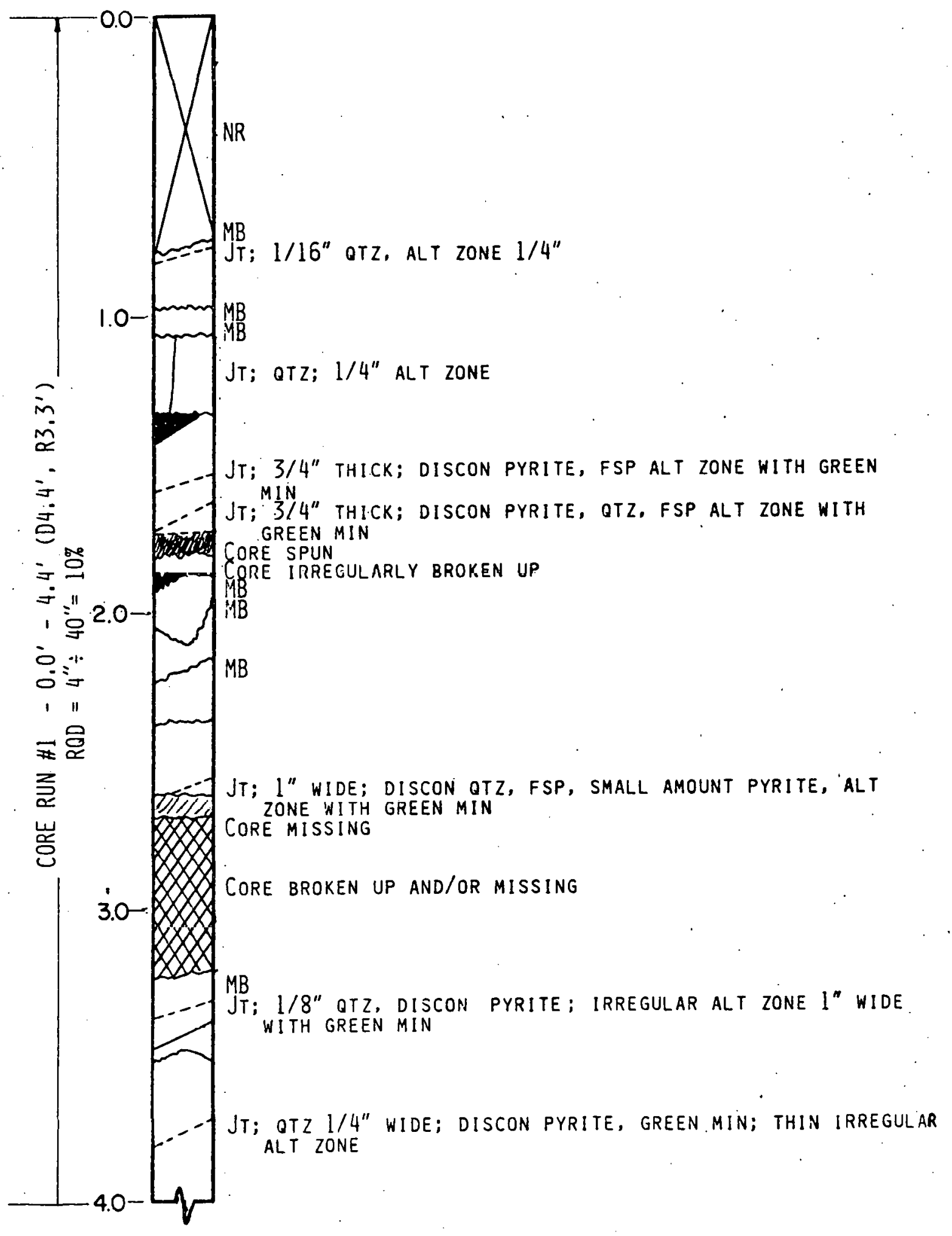

FIG. B-4a North Heater Hole \#4 


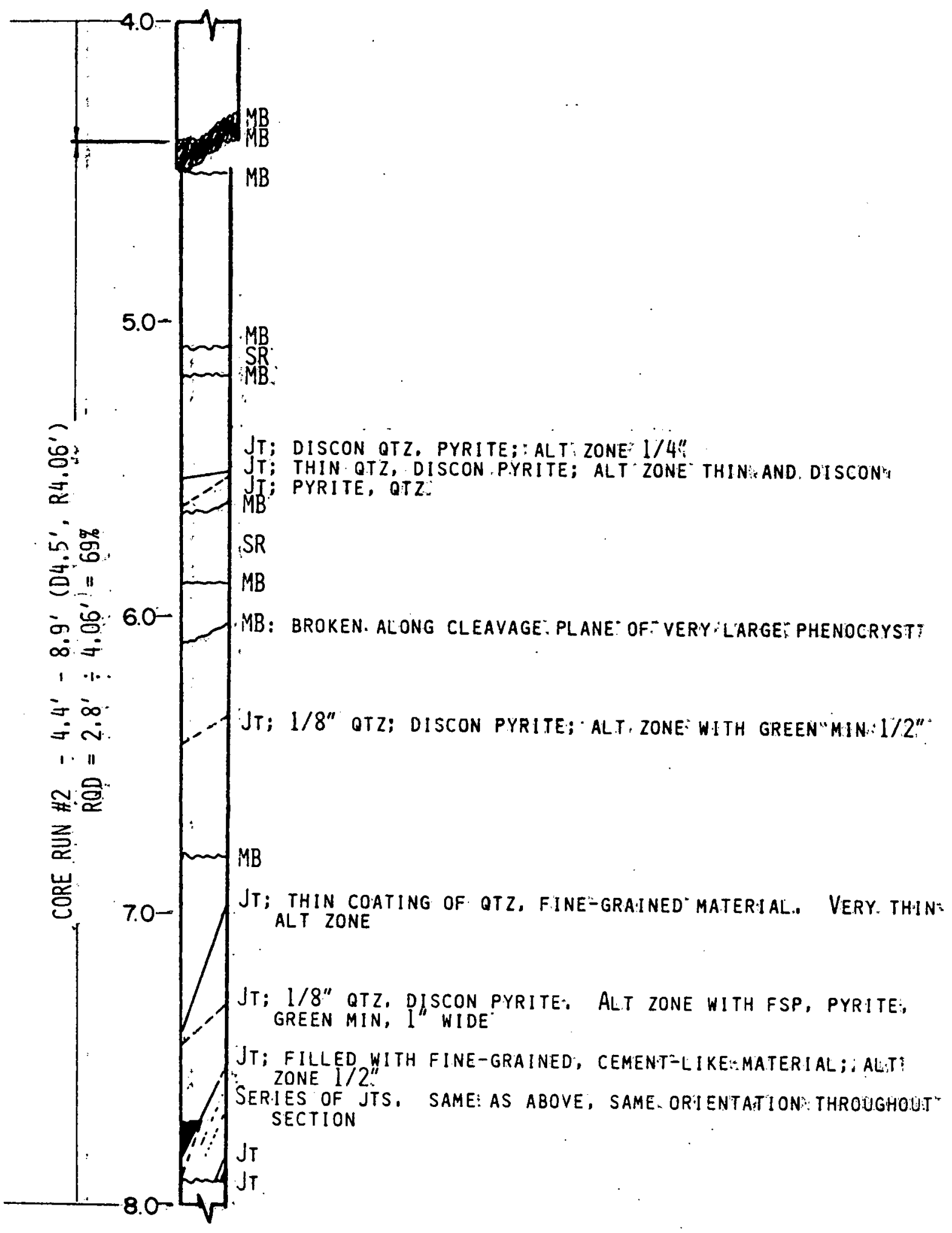

FIG: B $-4 b \quad(\mathrm{NHH}-4)$ ! 


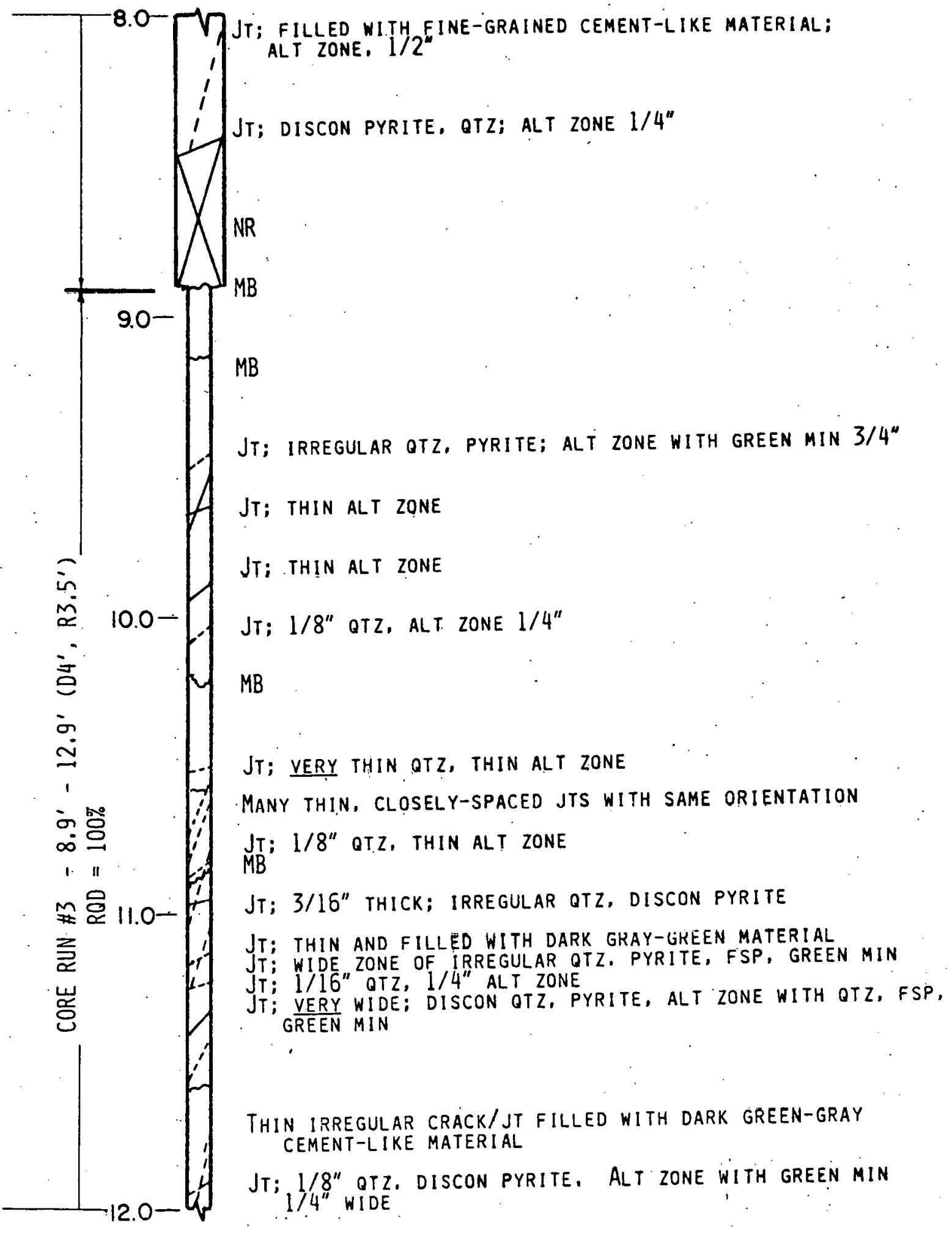

FIG. B-4C. (NHH-4) 


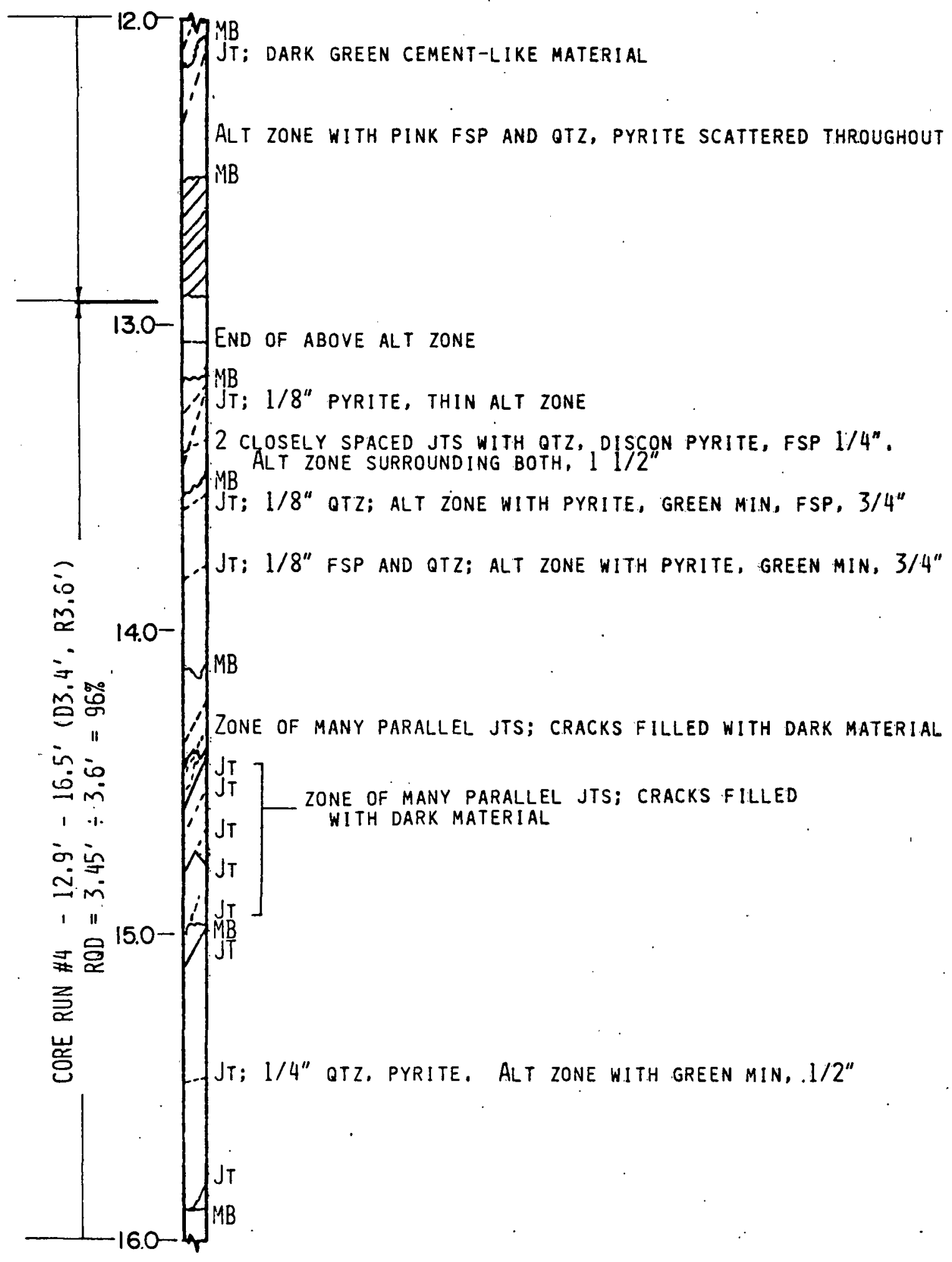

FIG. B-4d (NHH-4) 


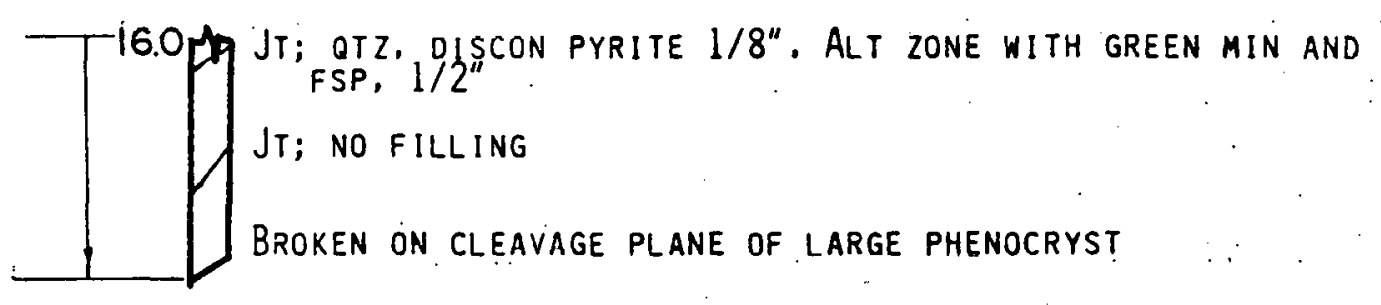

FIG. B-4e (NHH-4)

- B19 - 


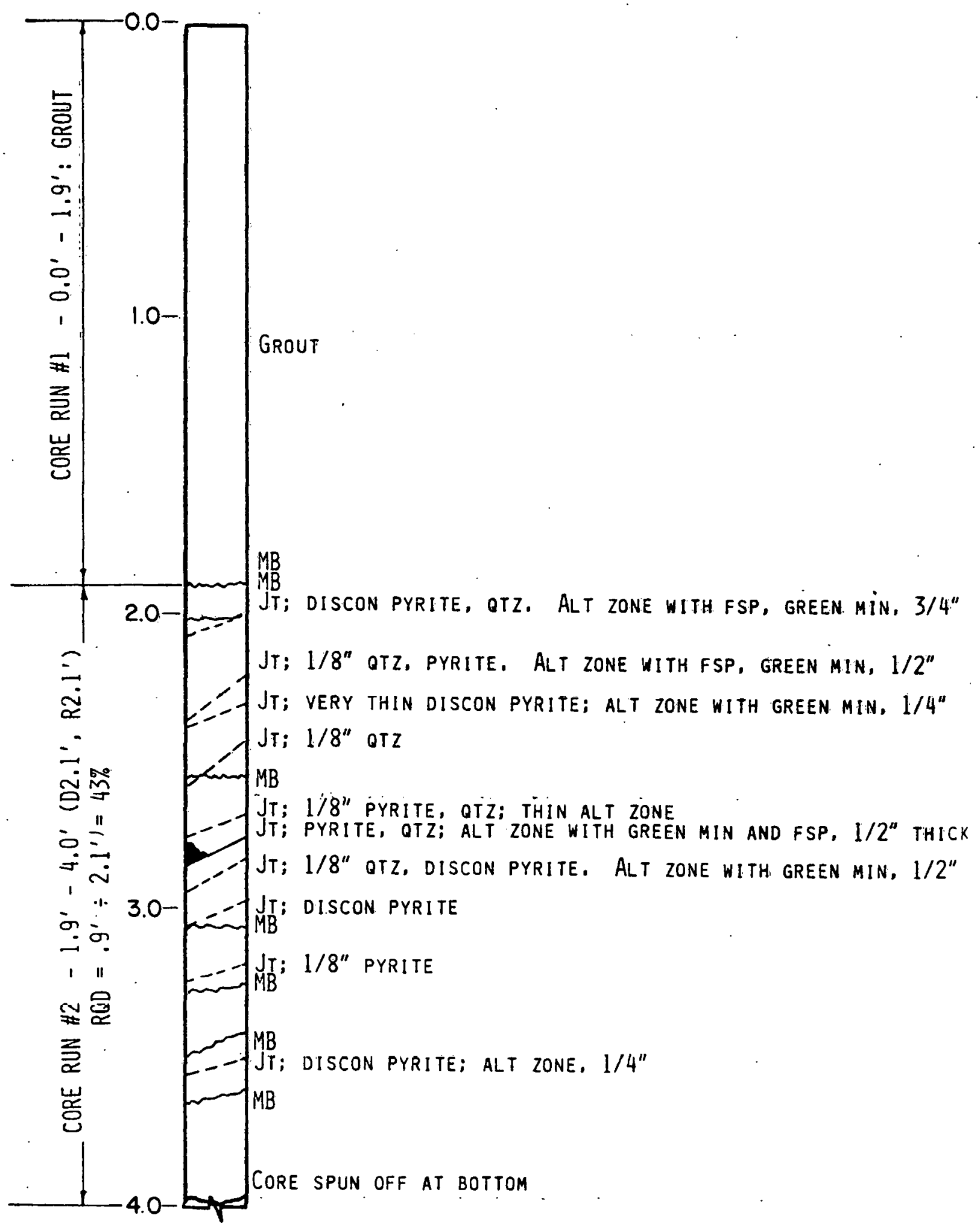

FIG. B-5a North Heater Hole \#5 


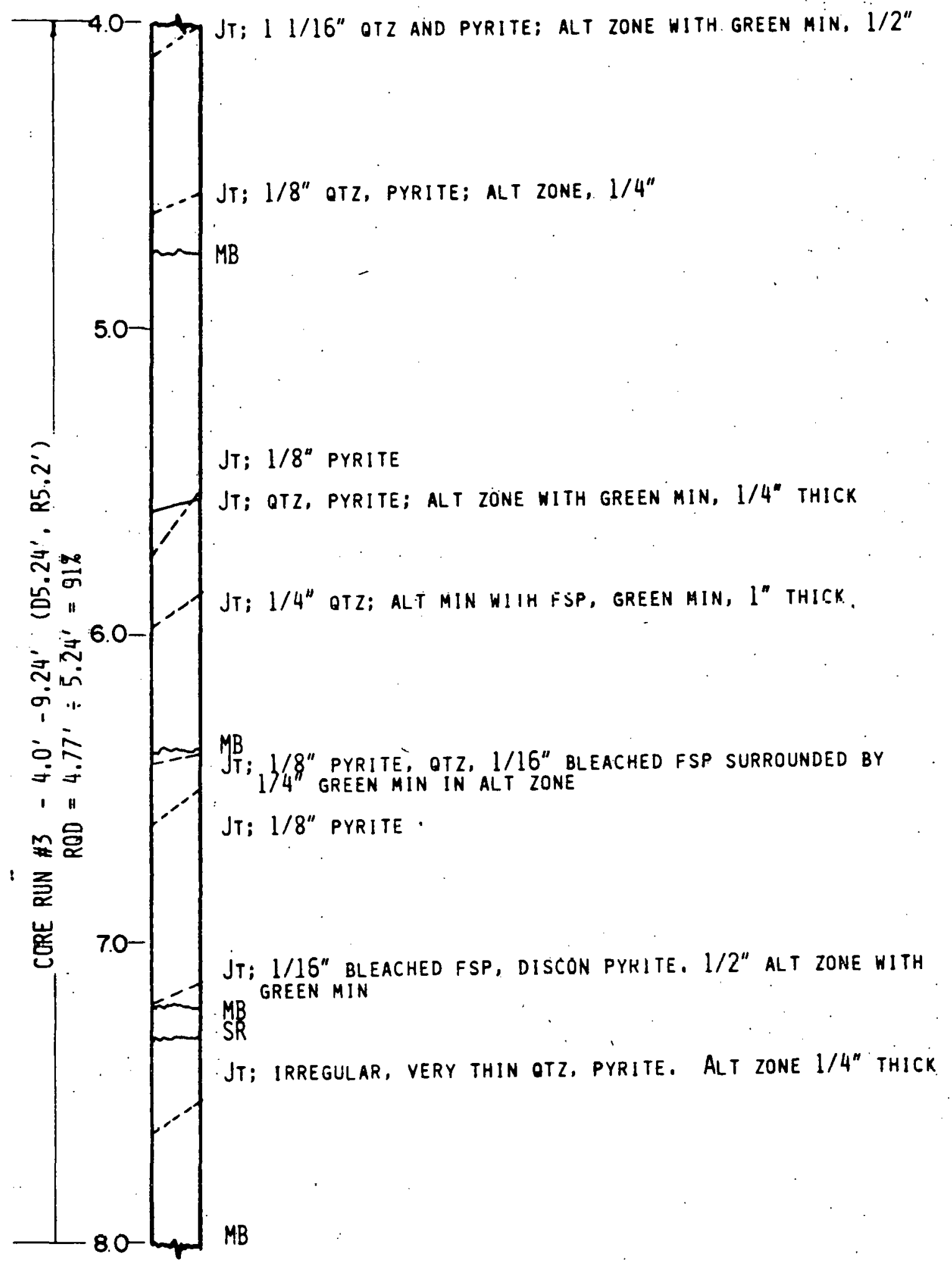

FIG. B-5b (NHH-5) 


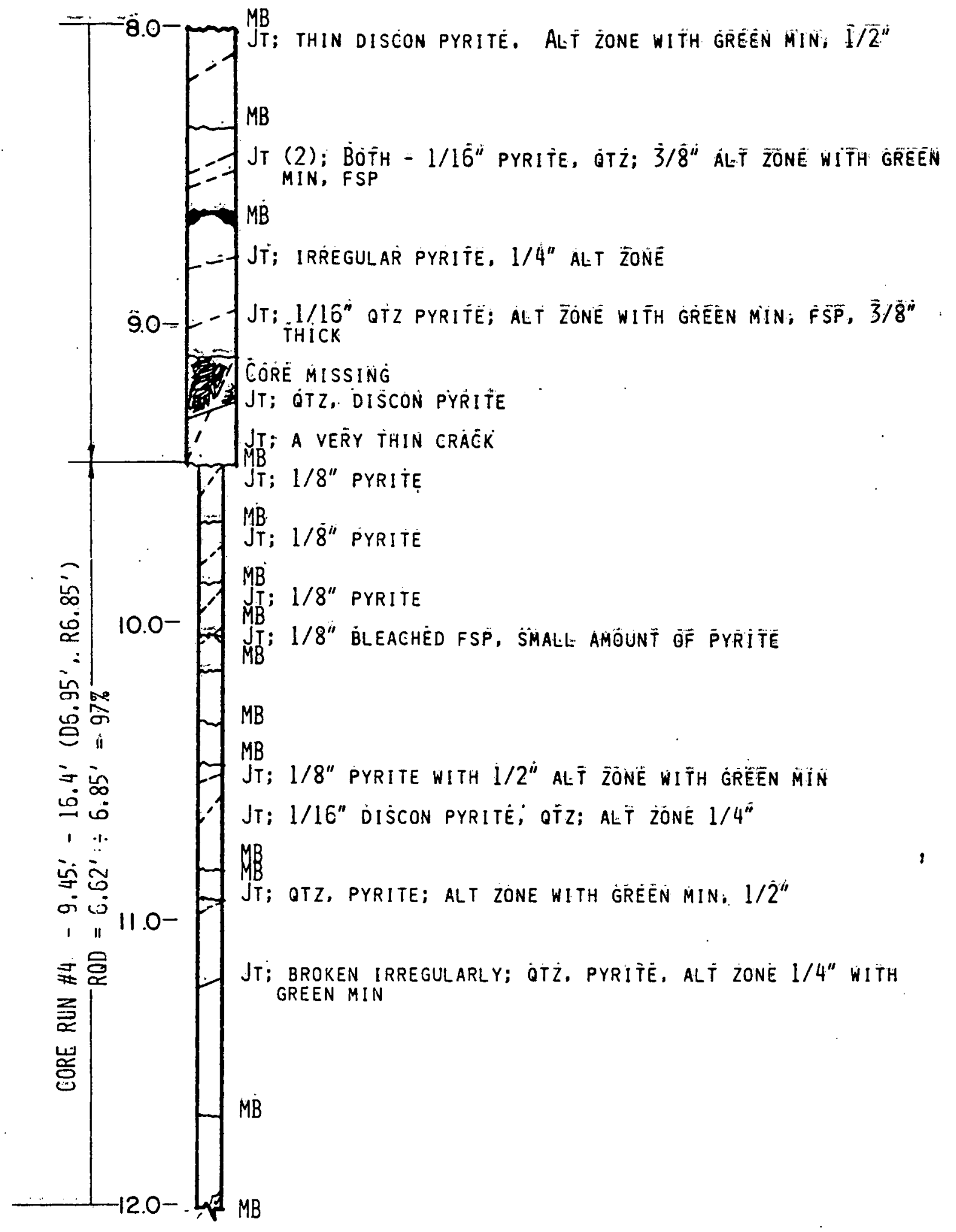

FìG. B $=\overline{5} \dot{C} \quad(\overline{N H H}=5)$ 


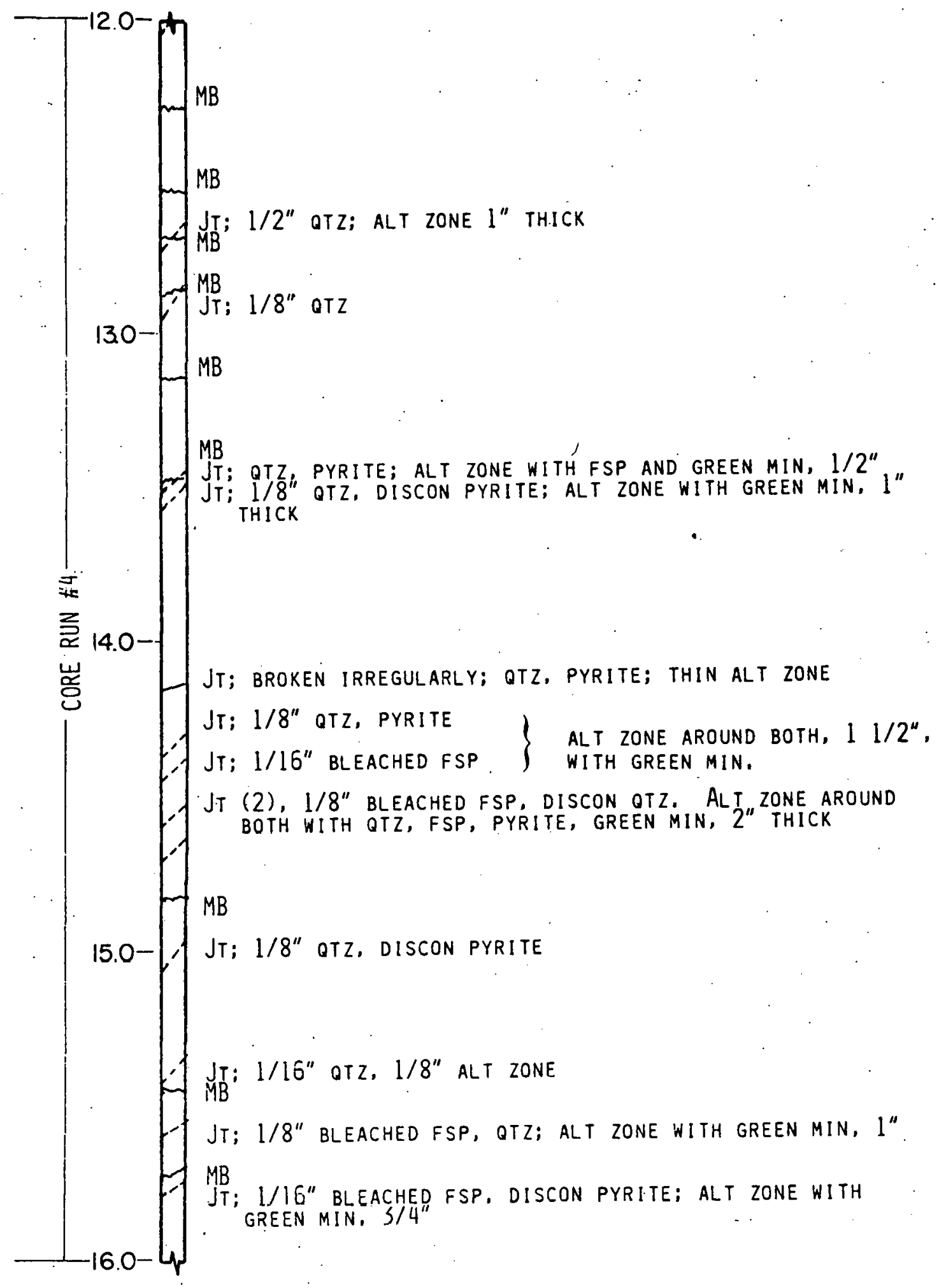

FIG. B-5d (NHH-5) 


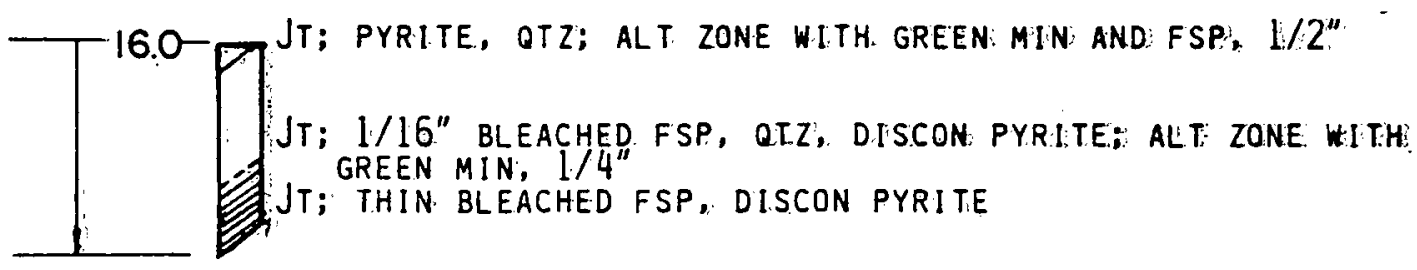

ZONE OF SIMILAR CLOSELY-SPACED JTS. PASS THROUGH LARGE. ZONED FSP. PHENOCRYST

FIG. B-5e (NHH-5) 


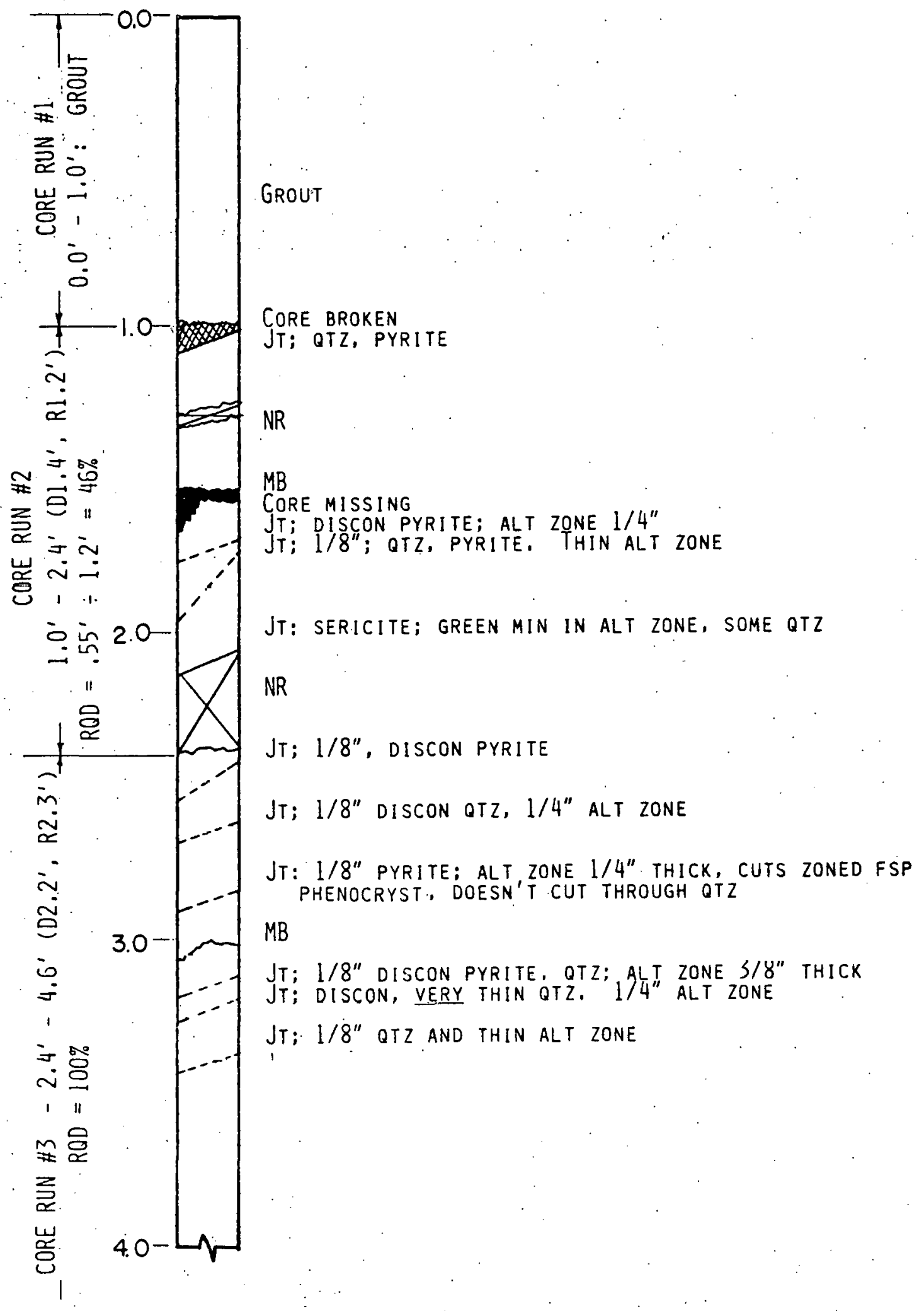

FIG. B-6a North Heater Hole \#6 


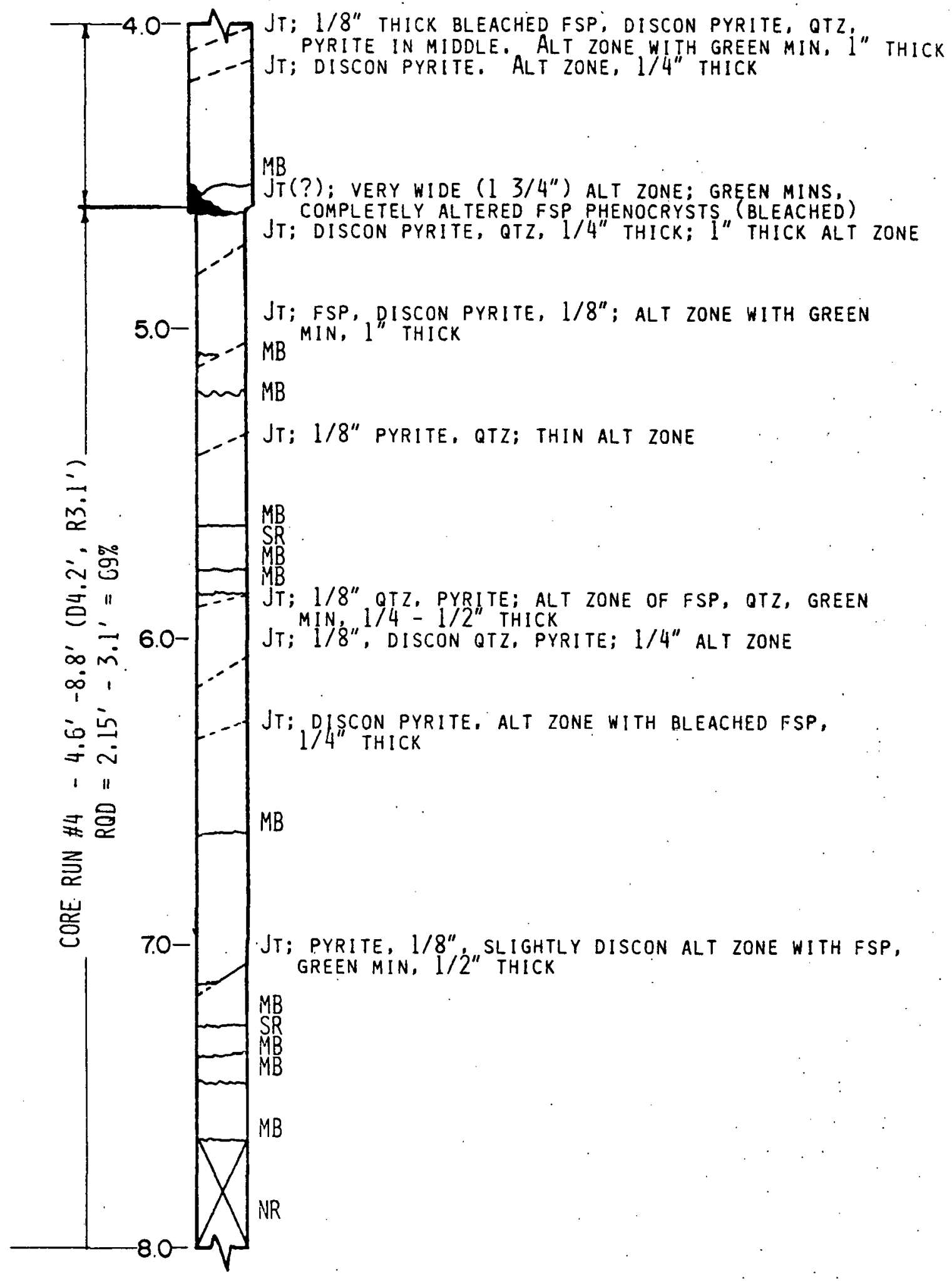

FIG. B-6b (NHH-6) 


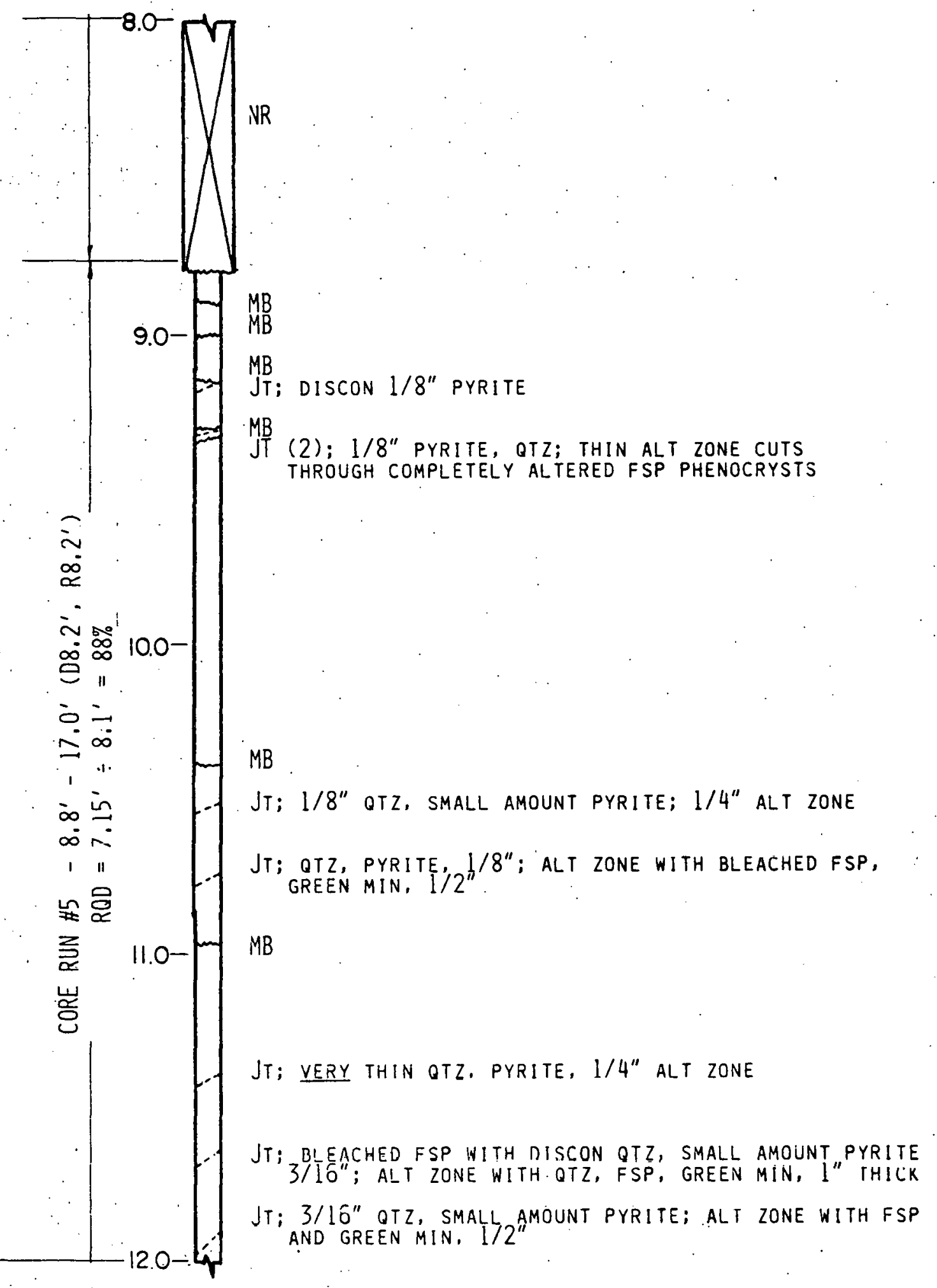

FIG. B-6C (NHH-6) 


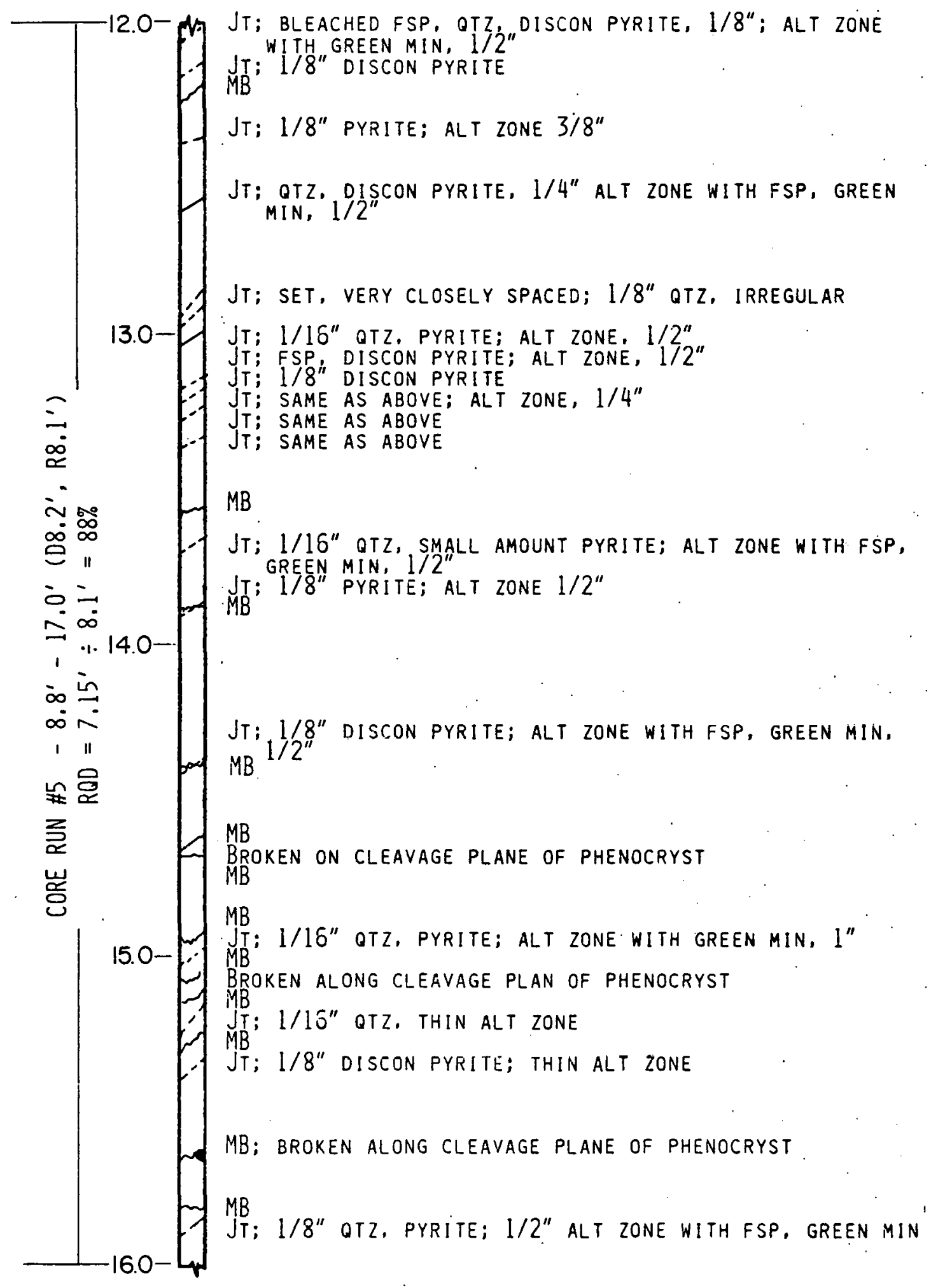

FIG. B-6d (NHH-6) 


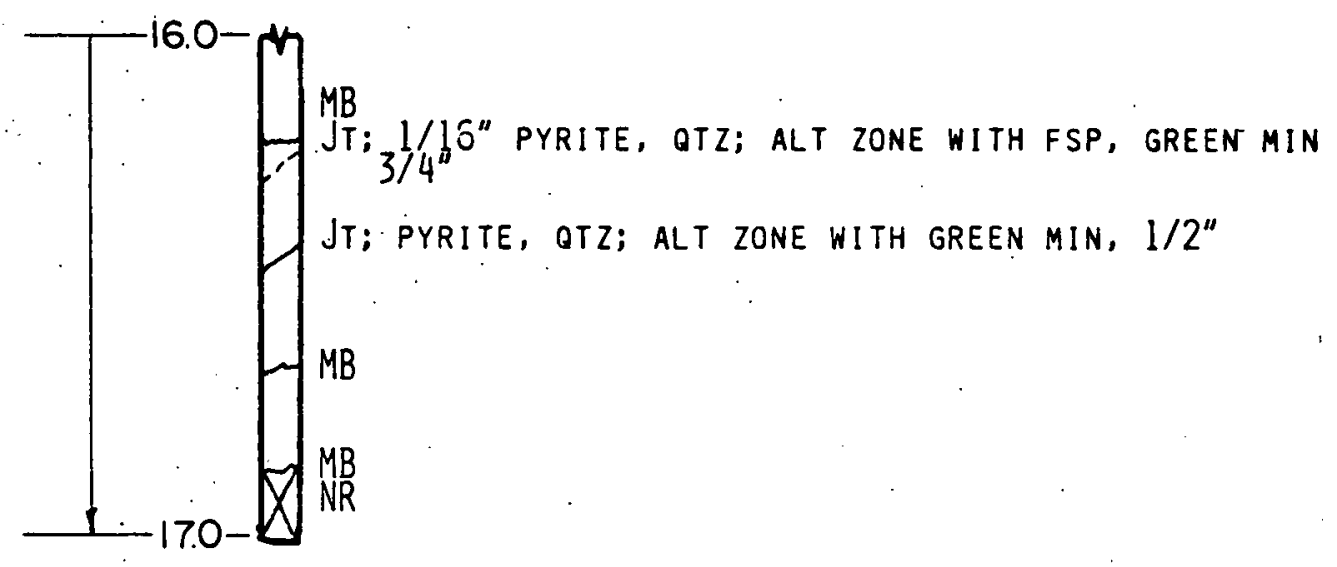

FIG. B-6e (NHH-6) 


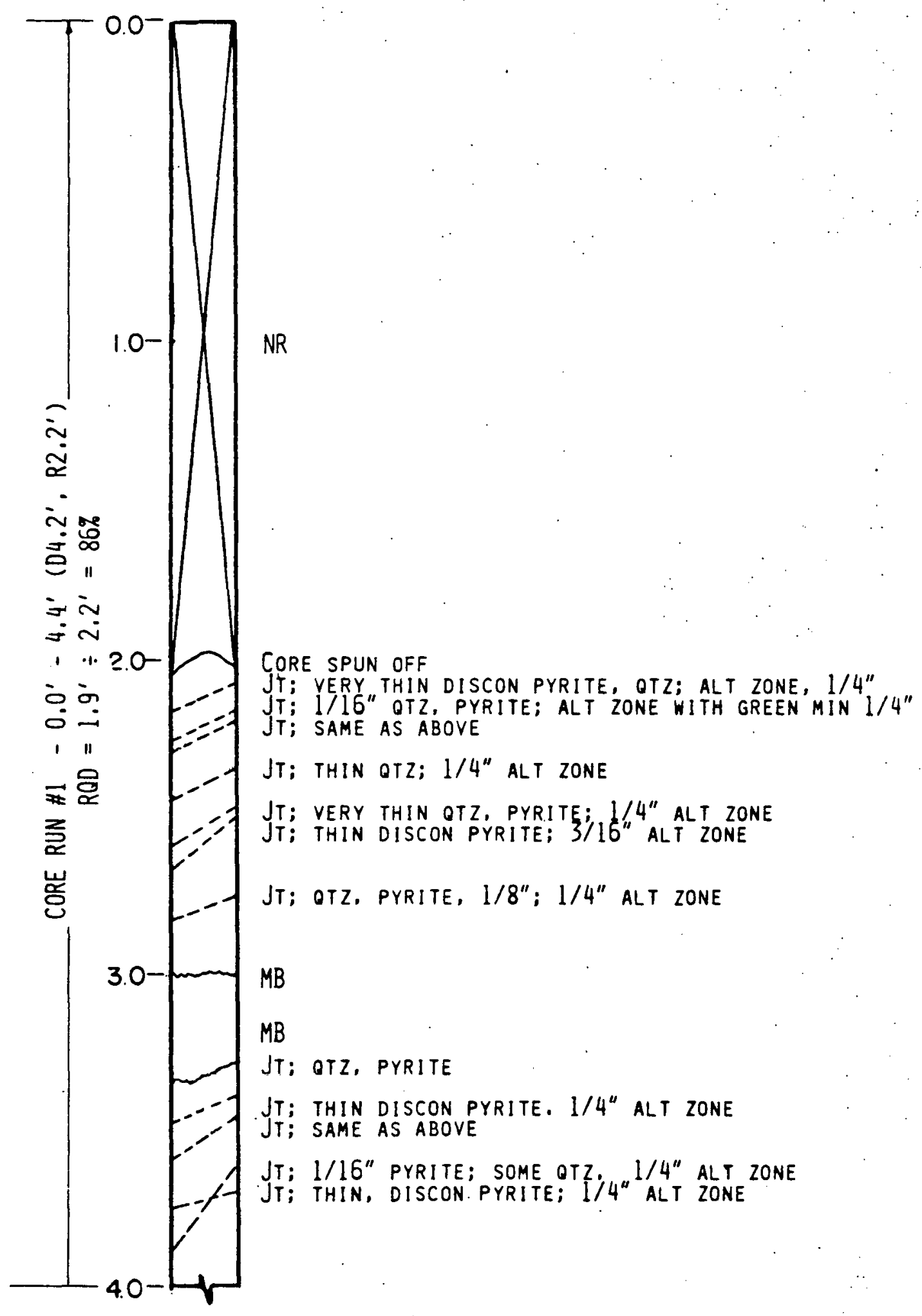

FIG. B-7a North Heater Hole \#7 


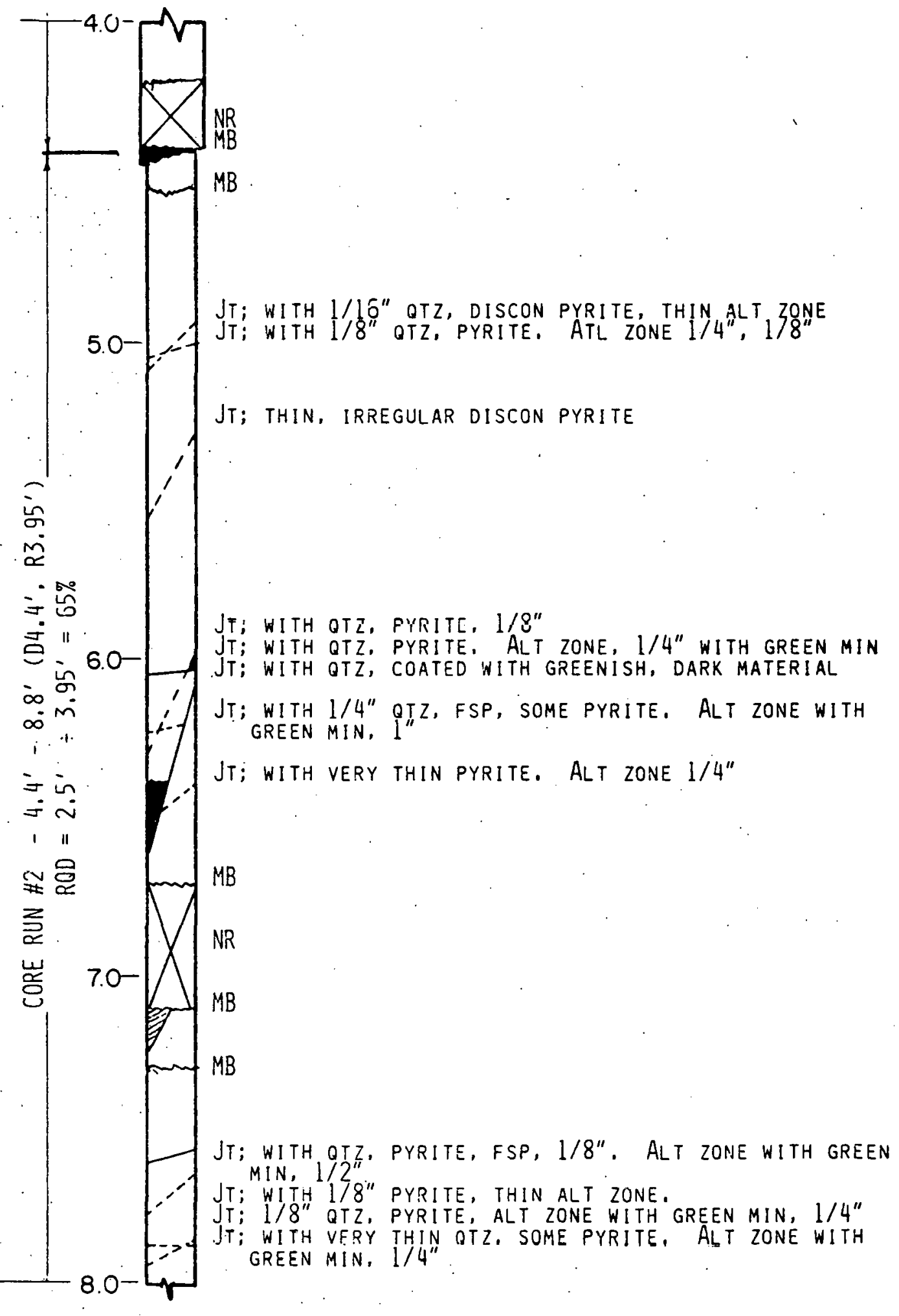

FIG. B-7b (NHH-7) 


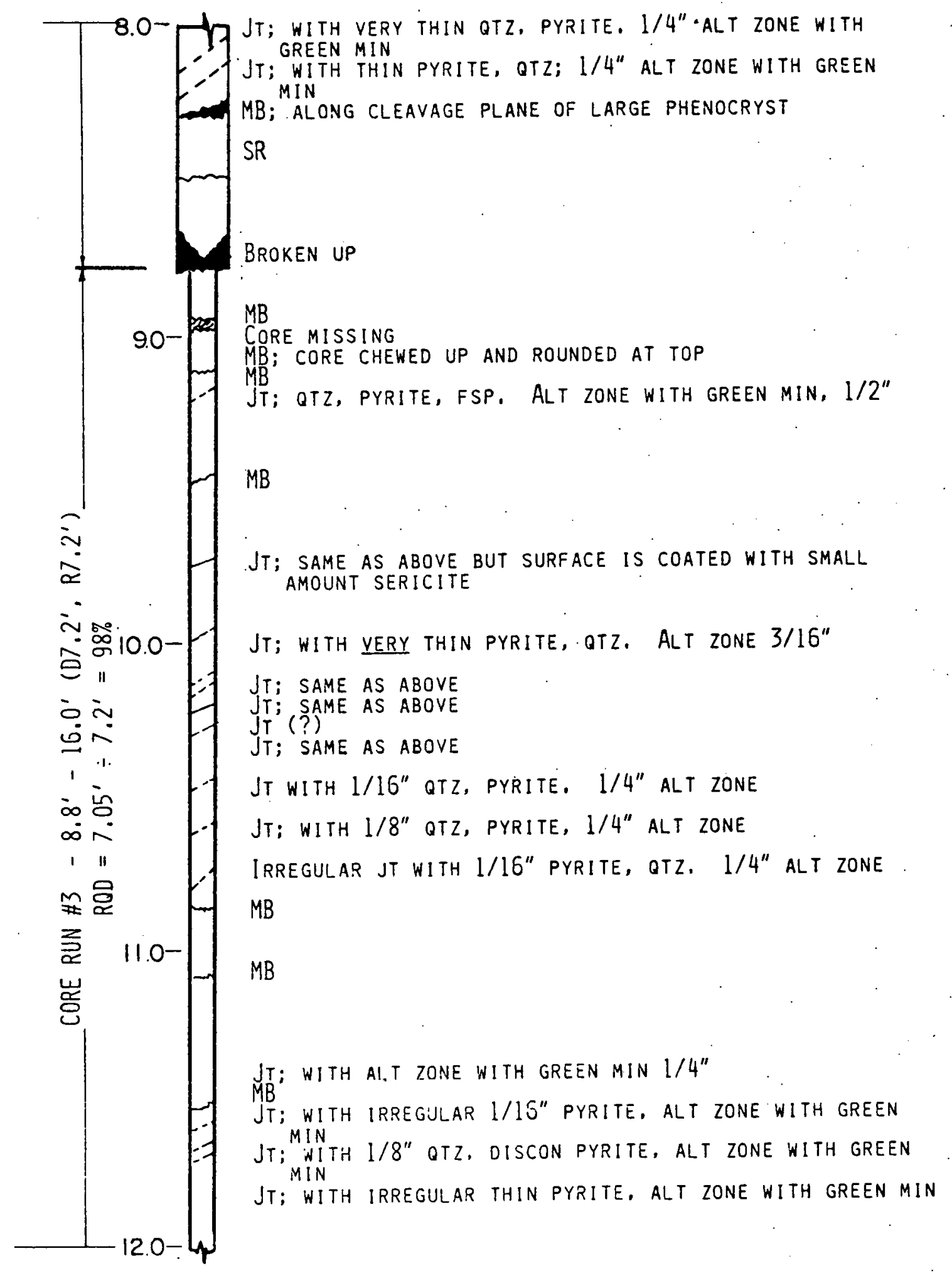

FIG. B-7C (NHH-7) 


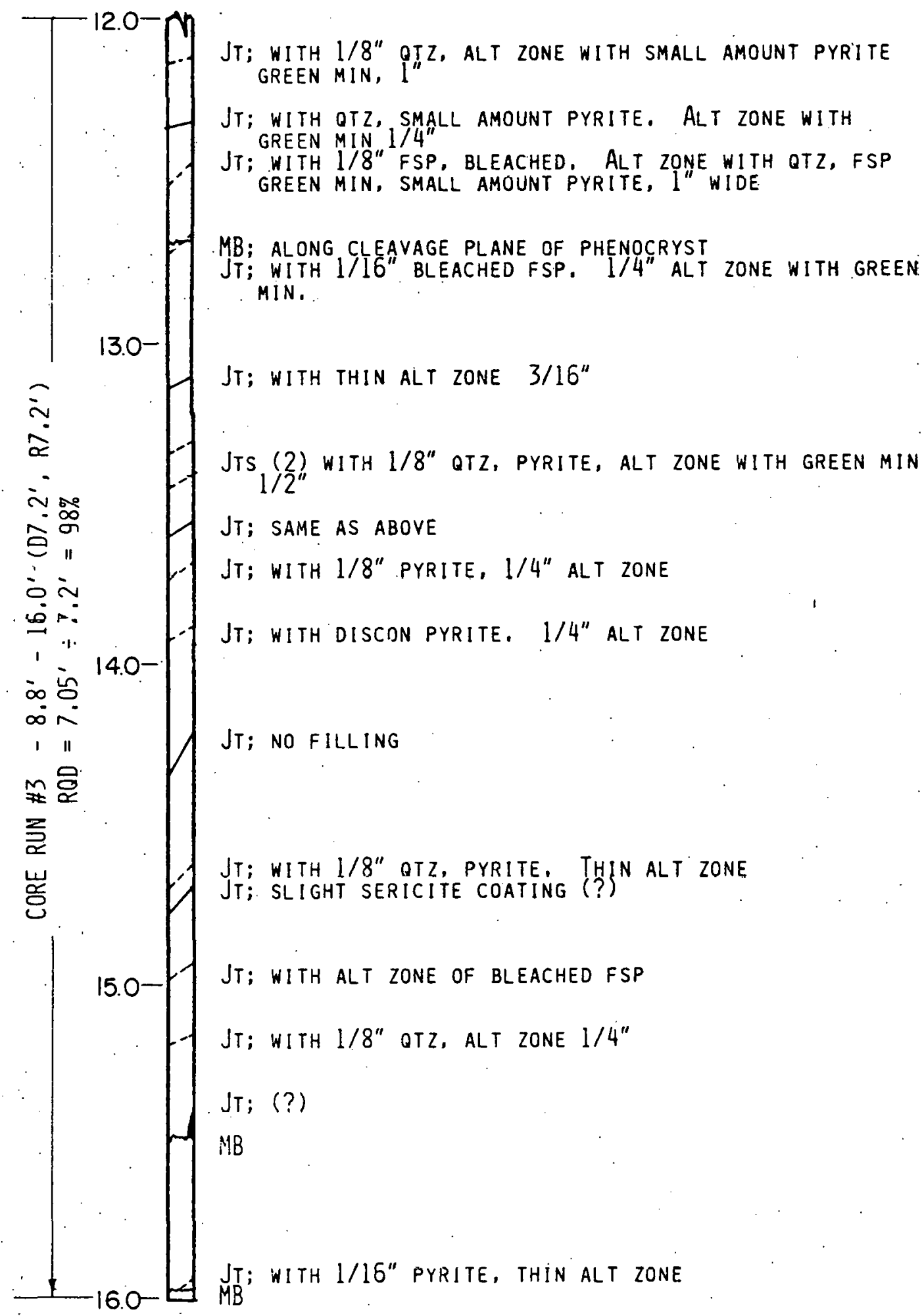

FIG. B-7d (NHH-7) 


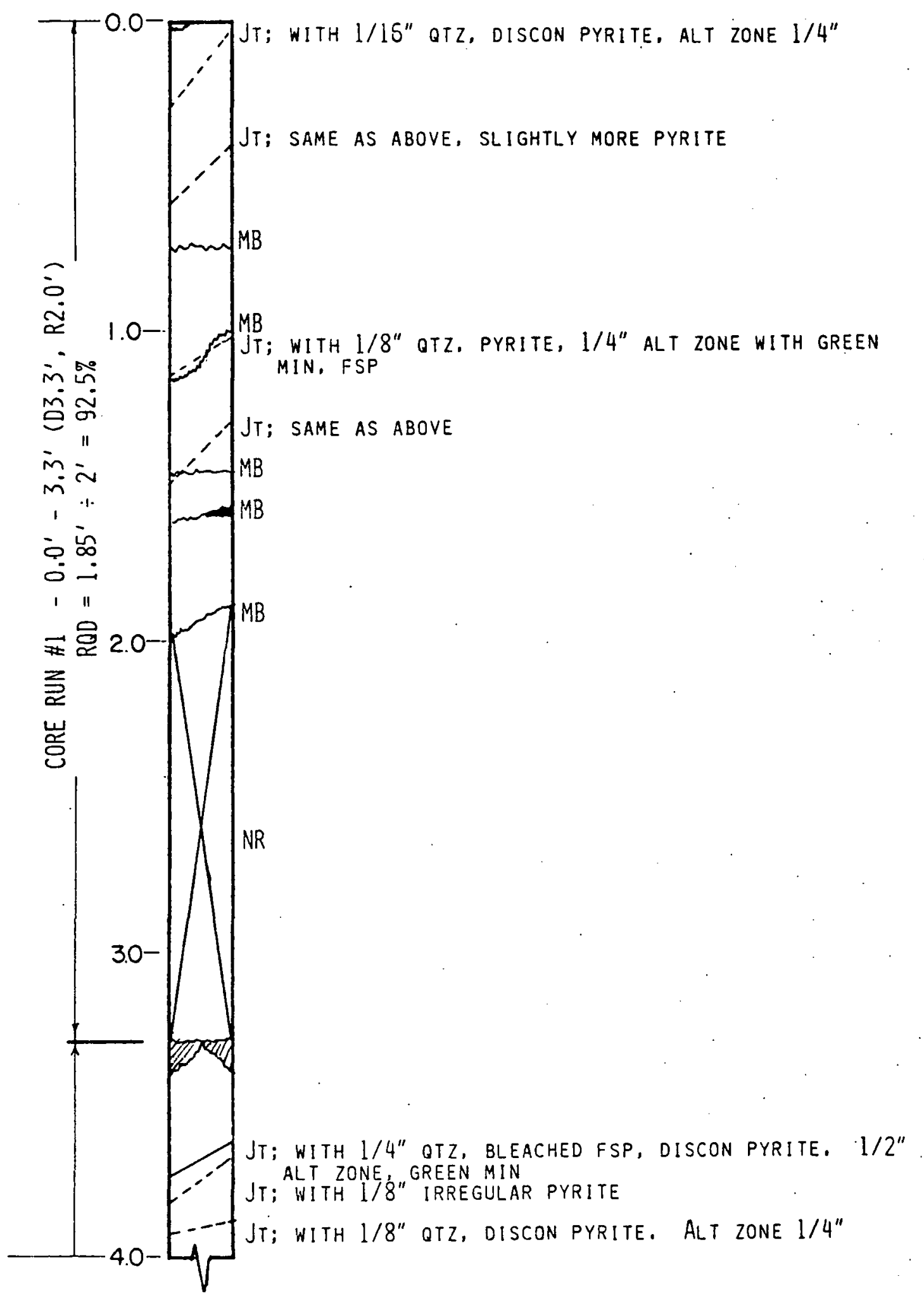

FIG. B-8a North Heater Hole \#8 


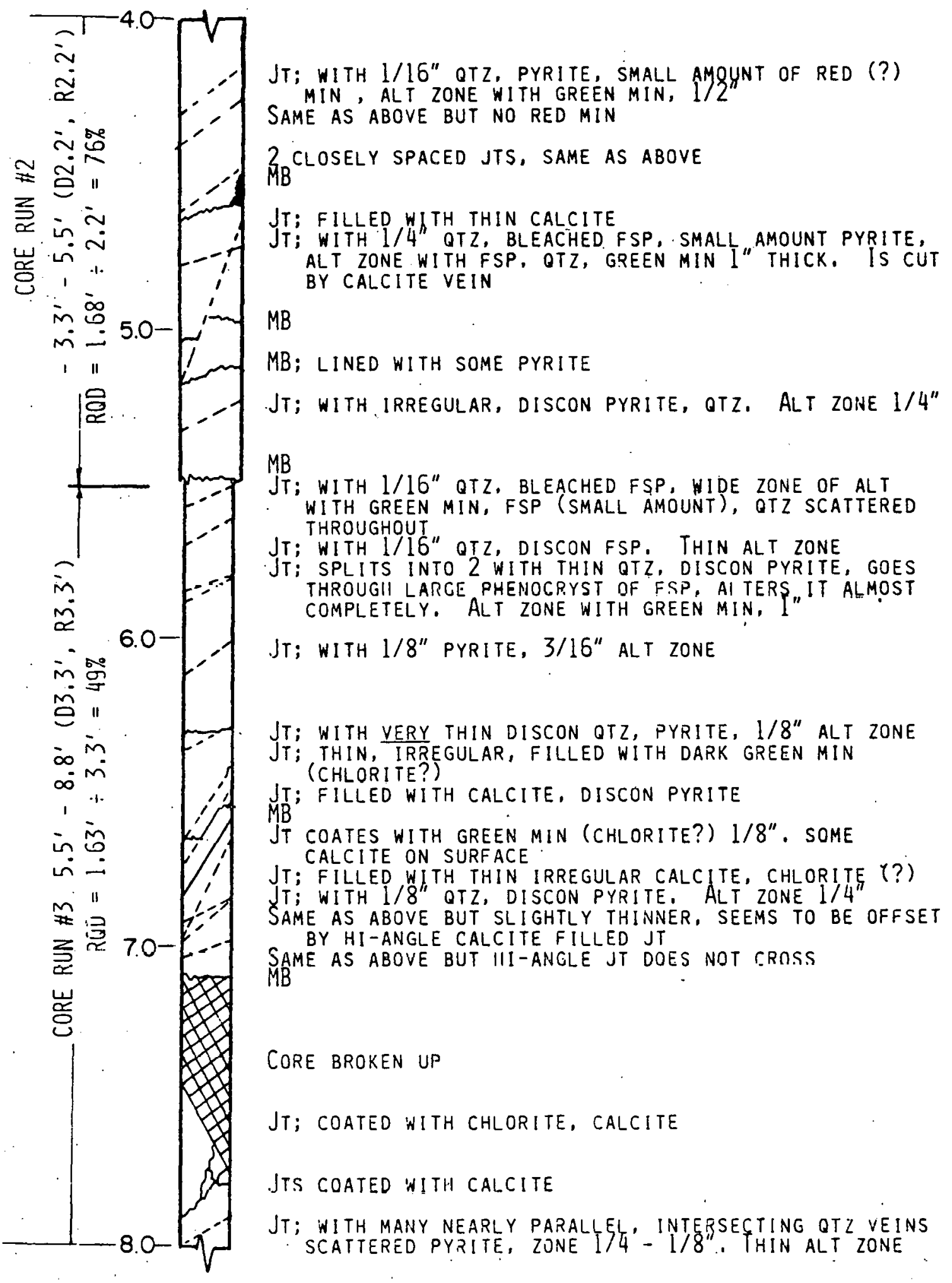

FIG. B-8b (NHH-8) 


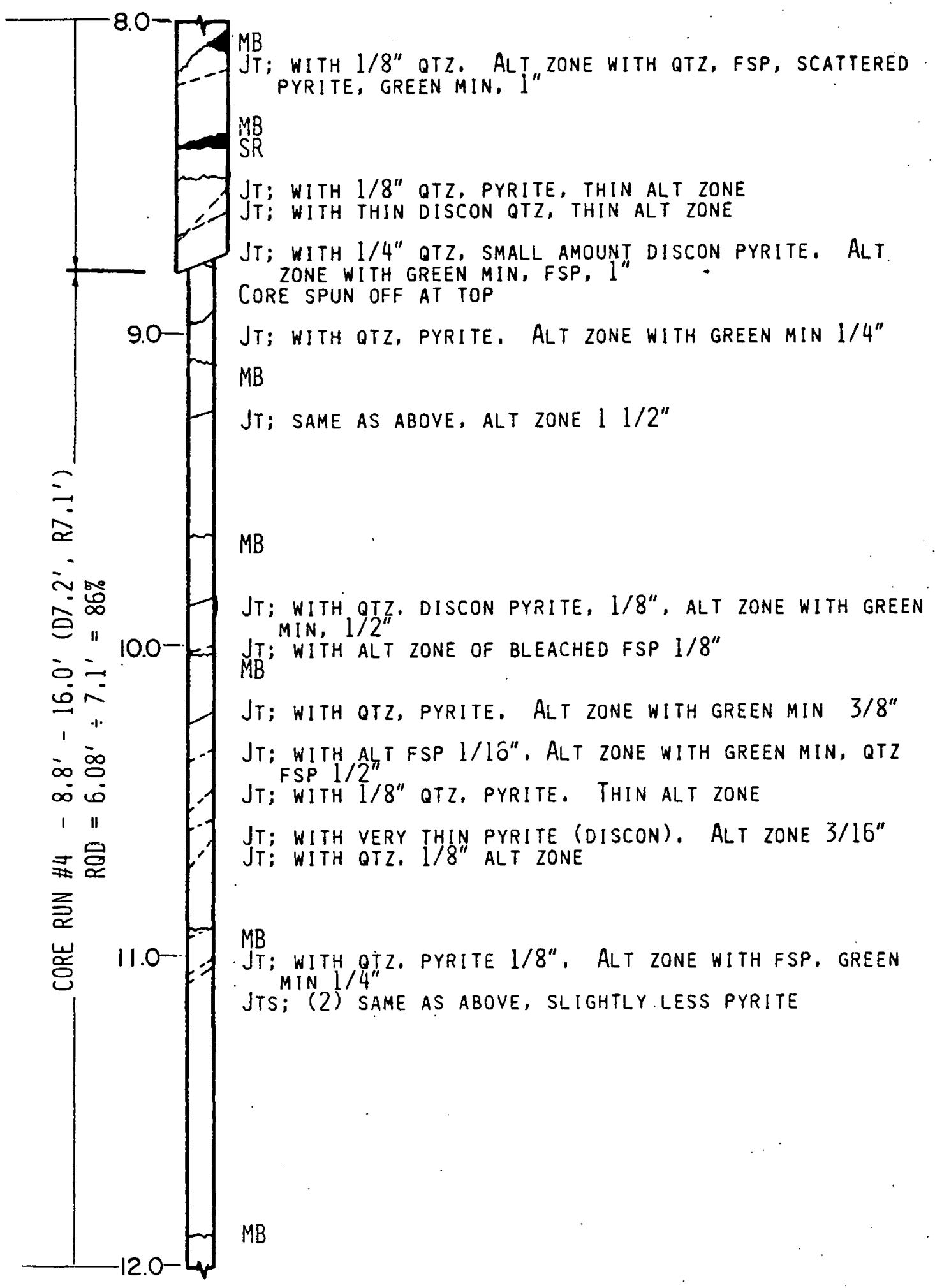

FIG. B-8C (NHH-8) 


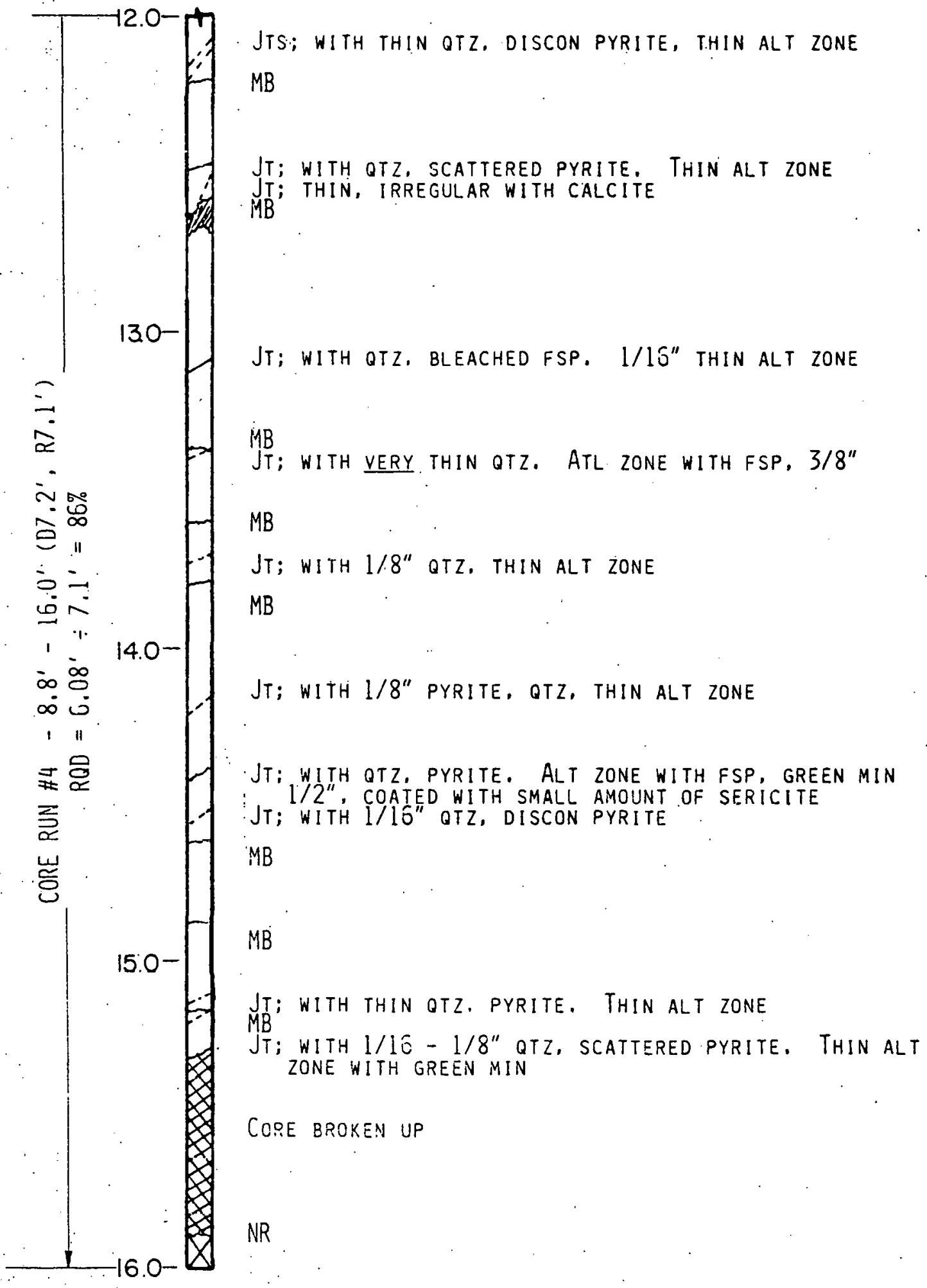

FIG. B-8d (NHH-8) 


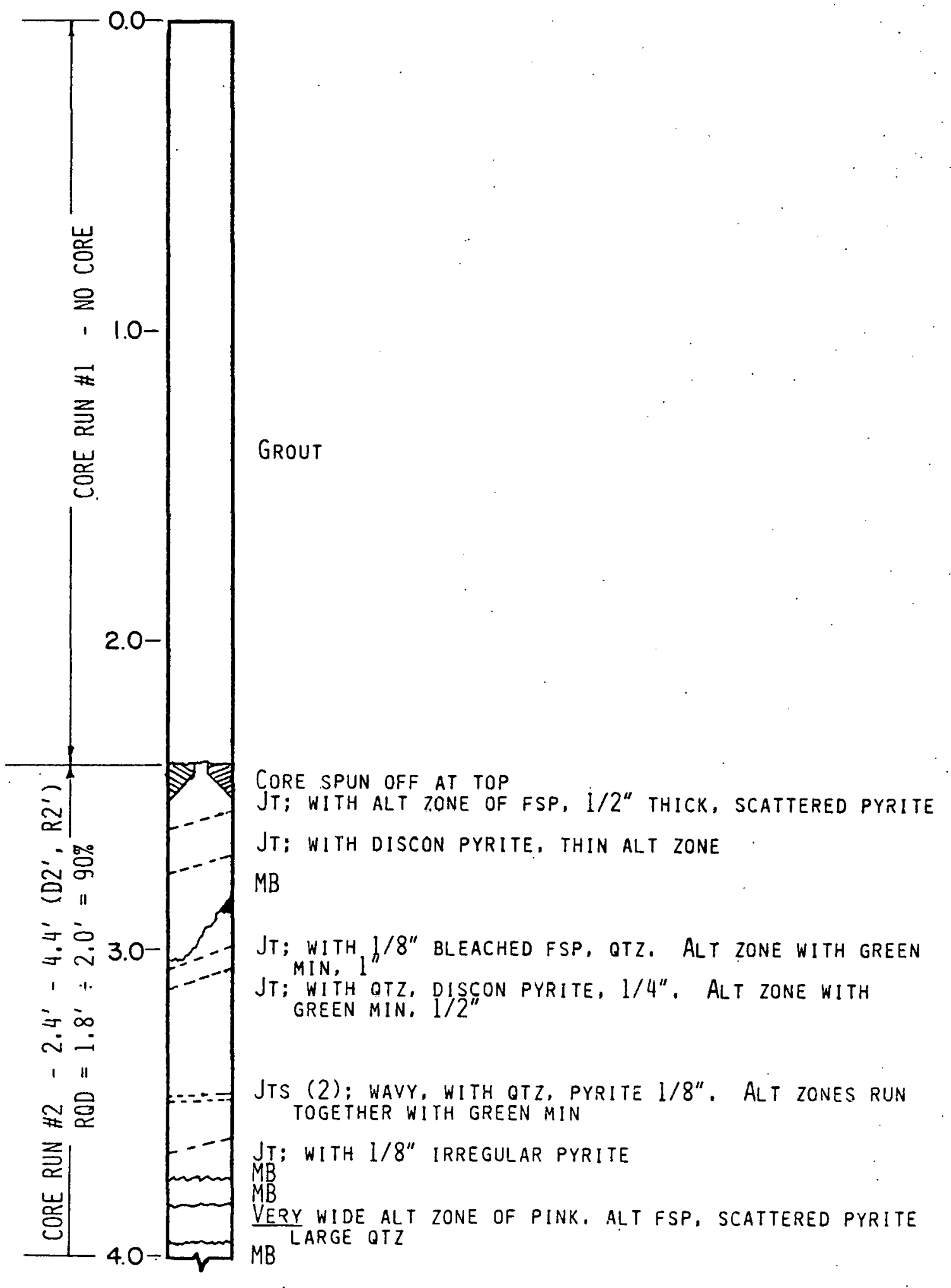

FIG. B-9a North Heater Hole \#9 


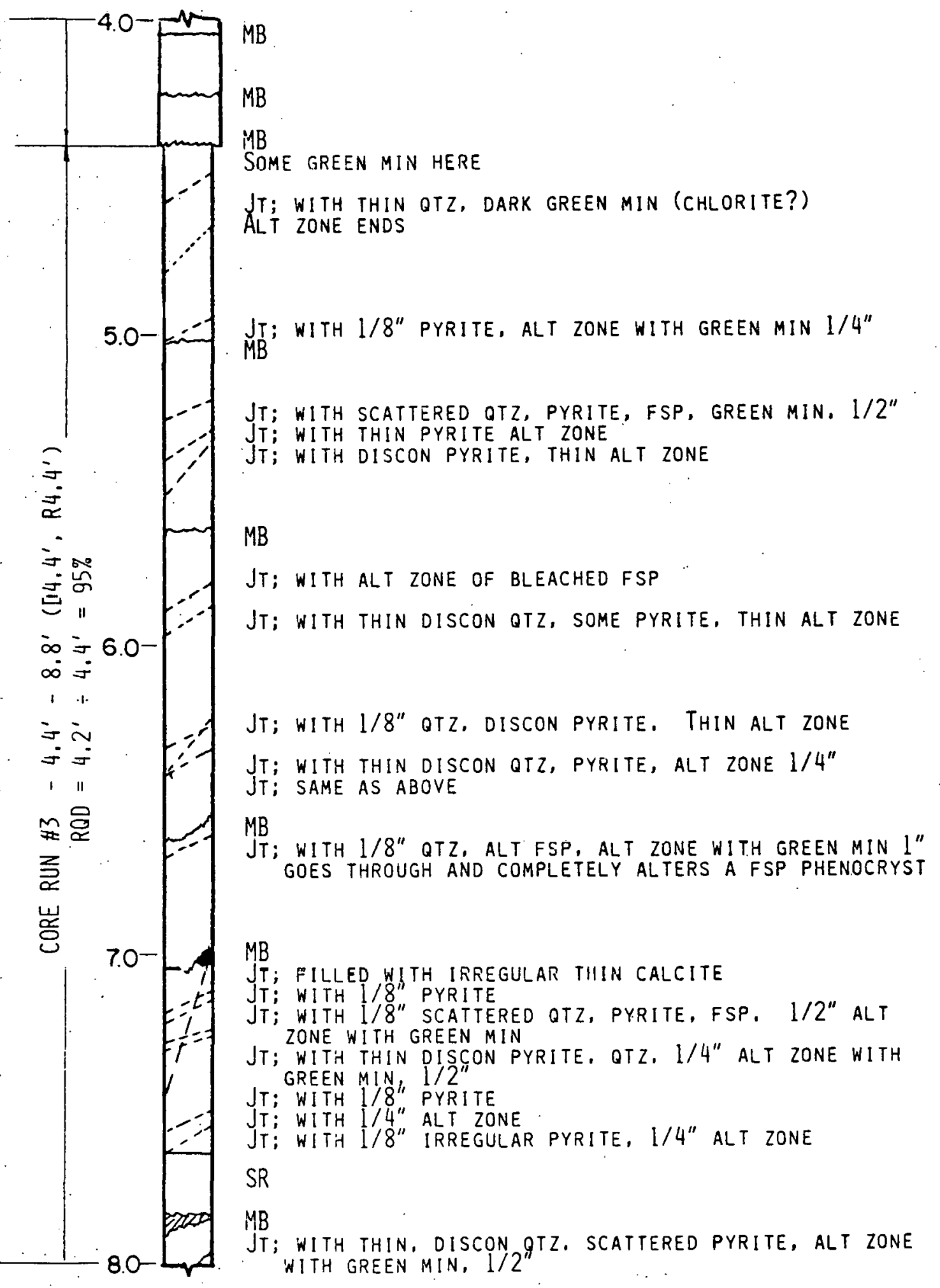

FIG. B-9b (NHH-9) 


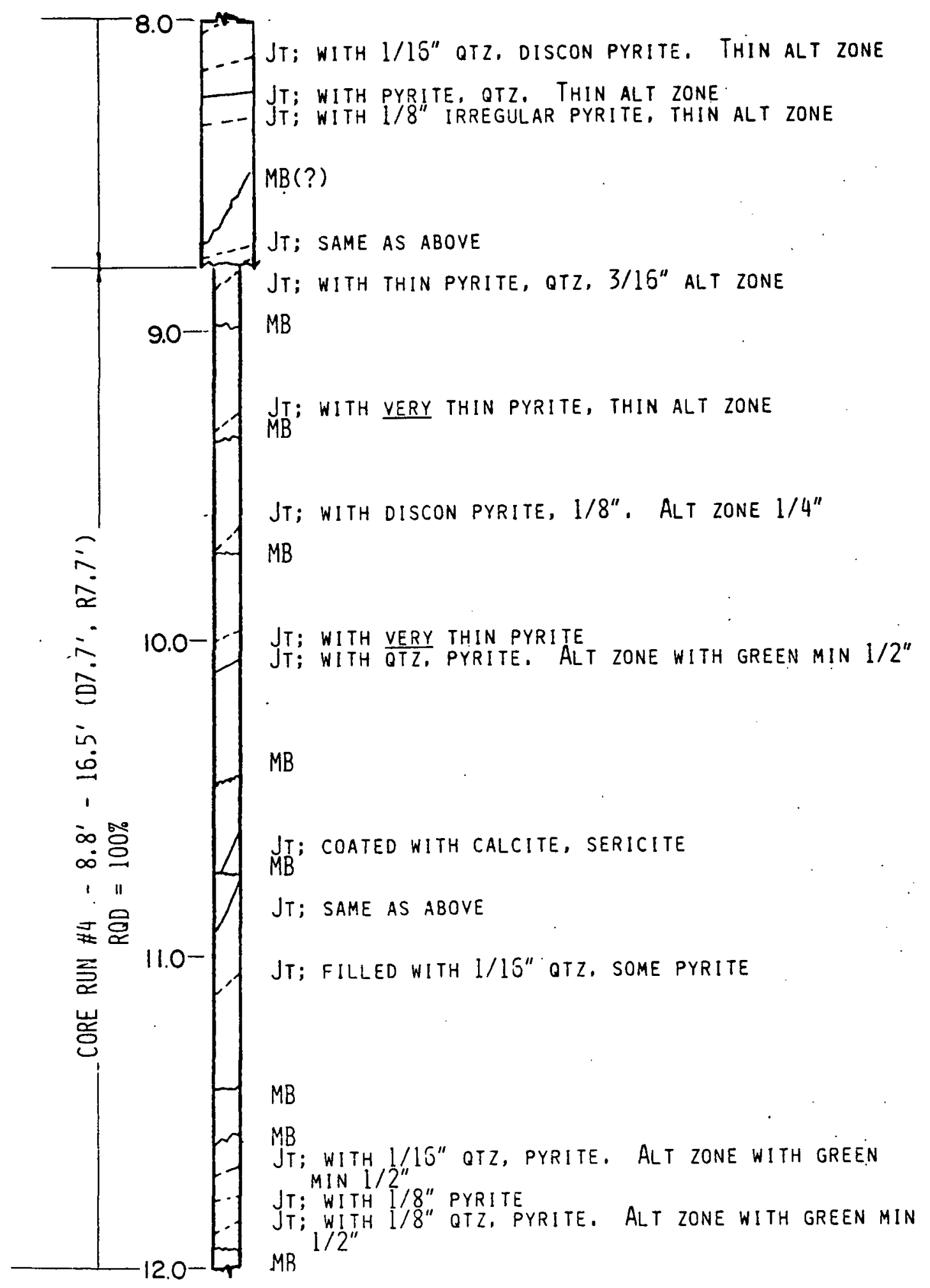

FIG. B-9c (NHH-9) 


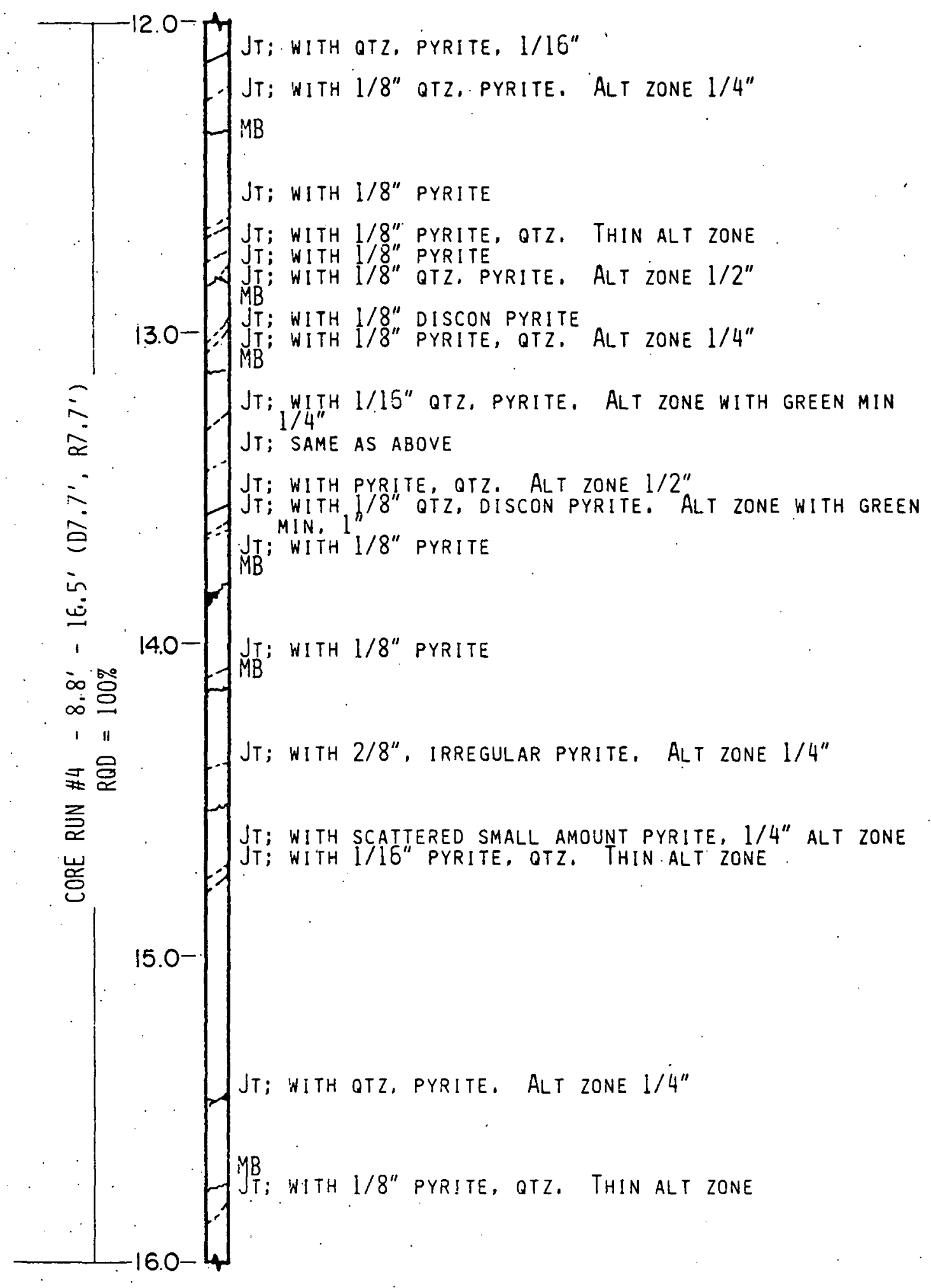

FIG. B-9d (NHH-9) 


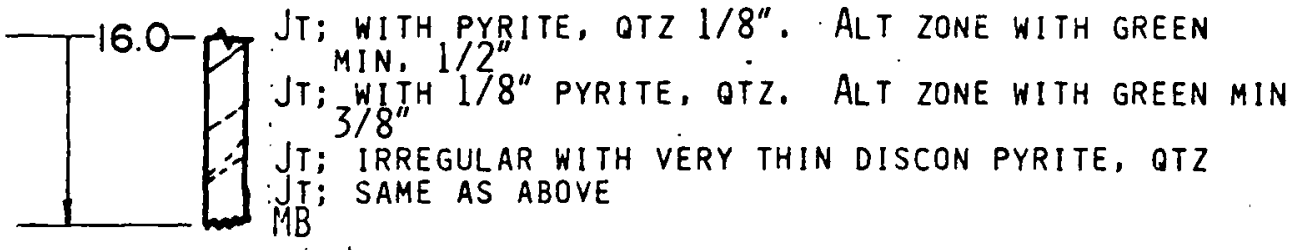

FIG. B-9e (NHH-9) 


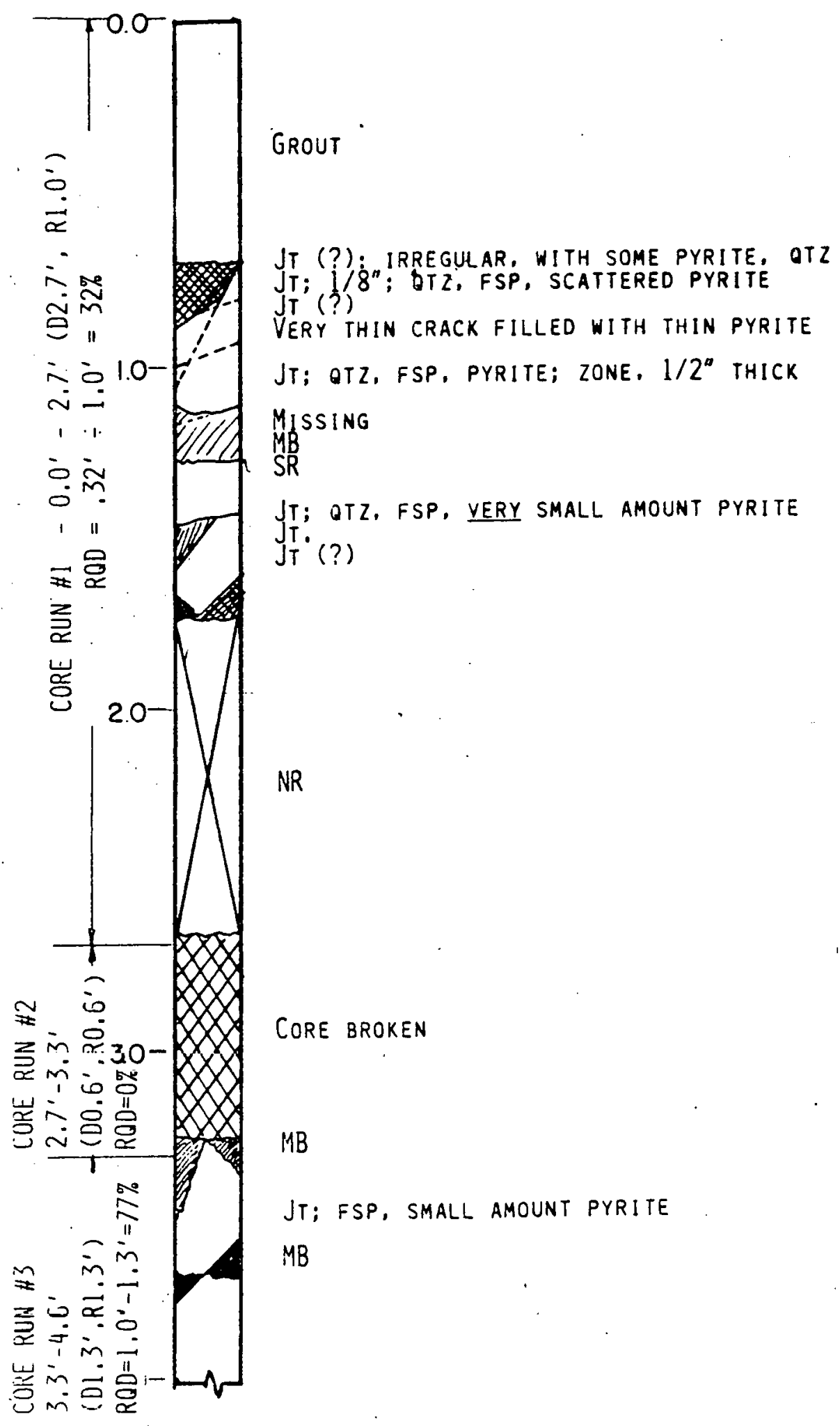

FIG. B-10a North Heater Hole \#10 


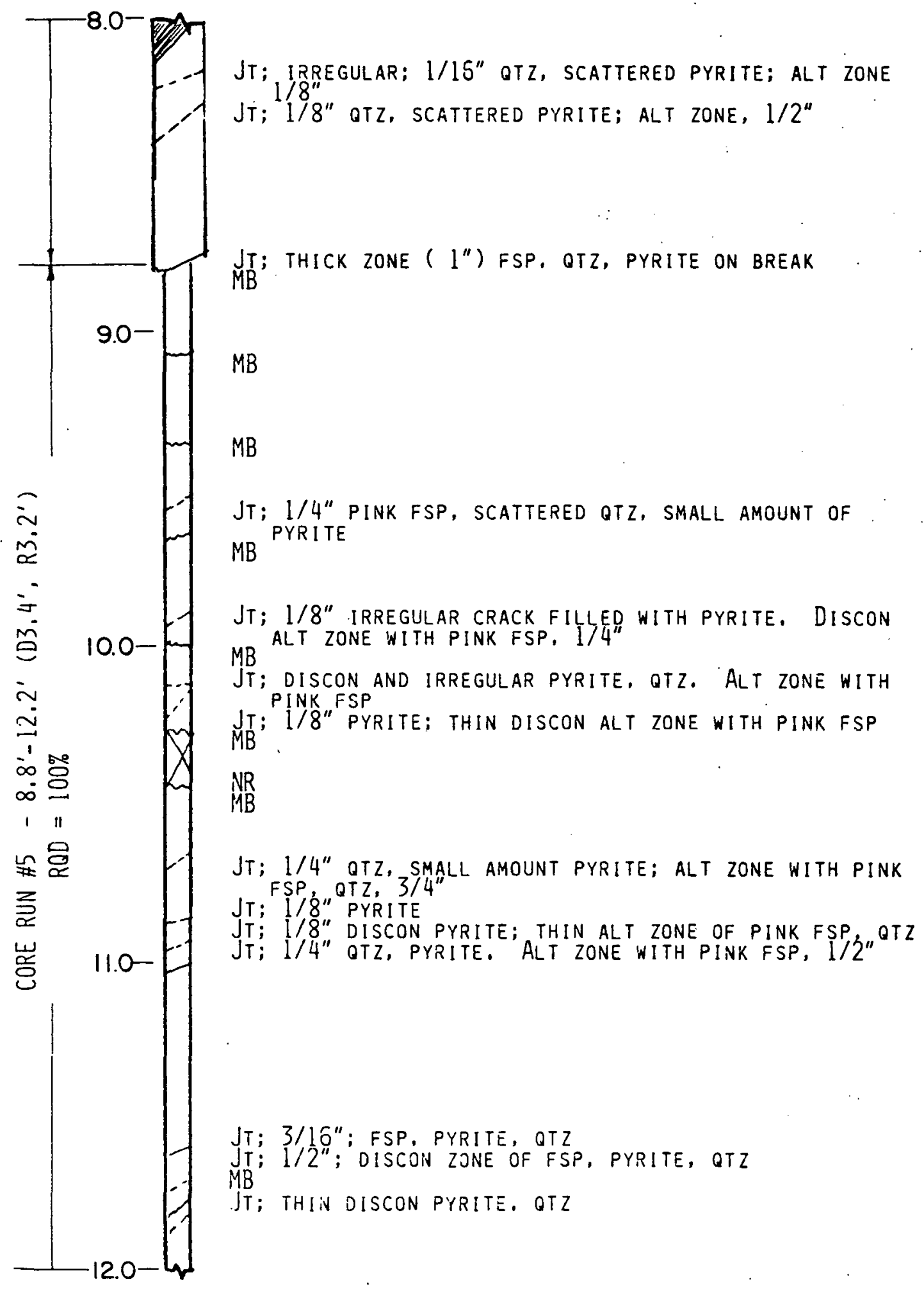

FIG. B-10b (NHH-10) 


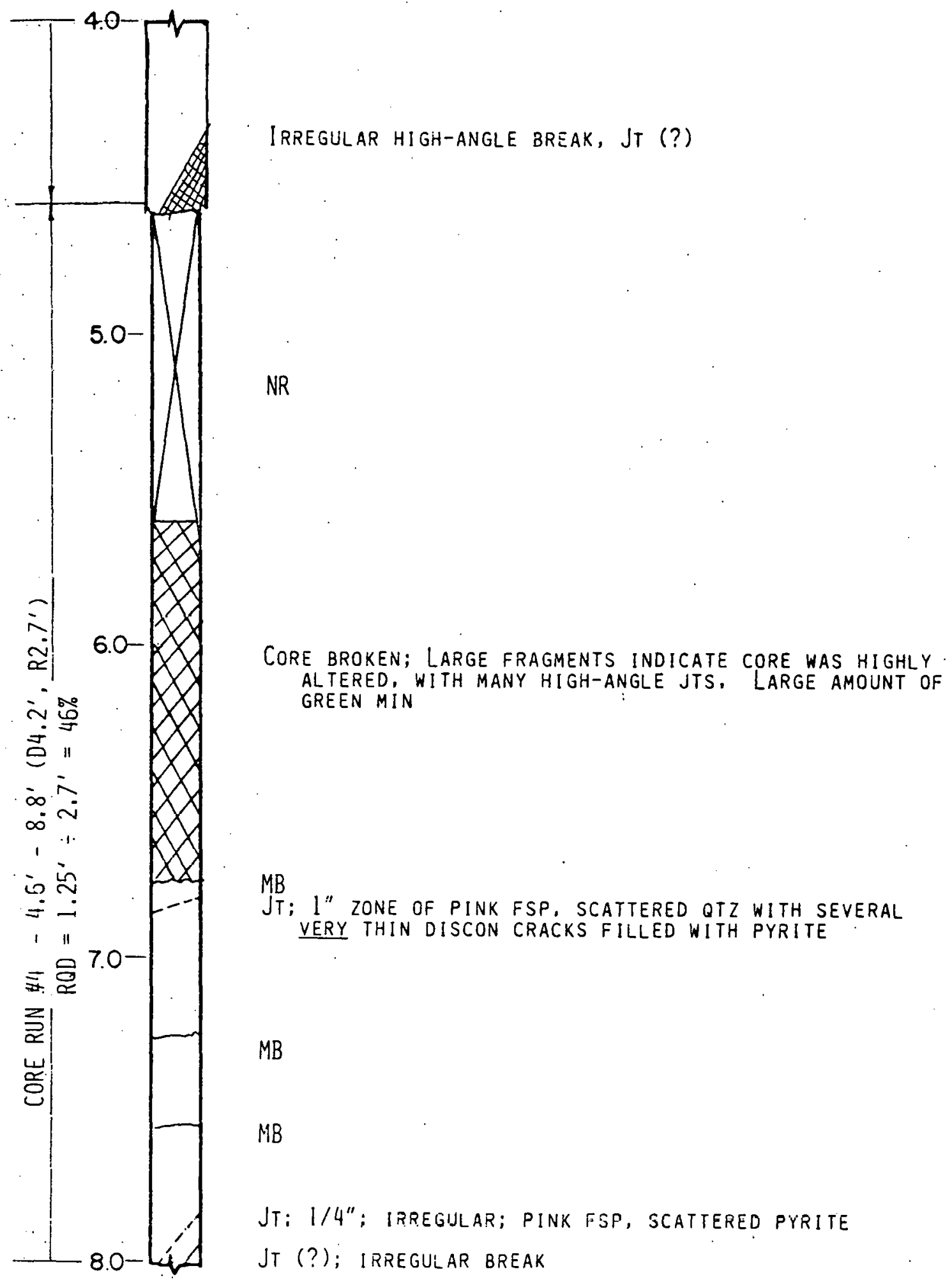

FIG. B-10C (NHH-10) 


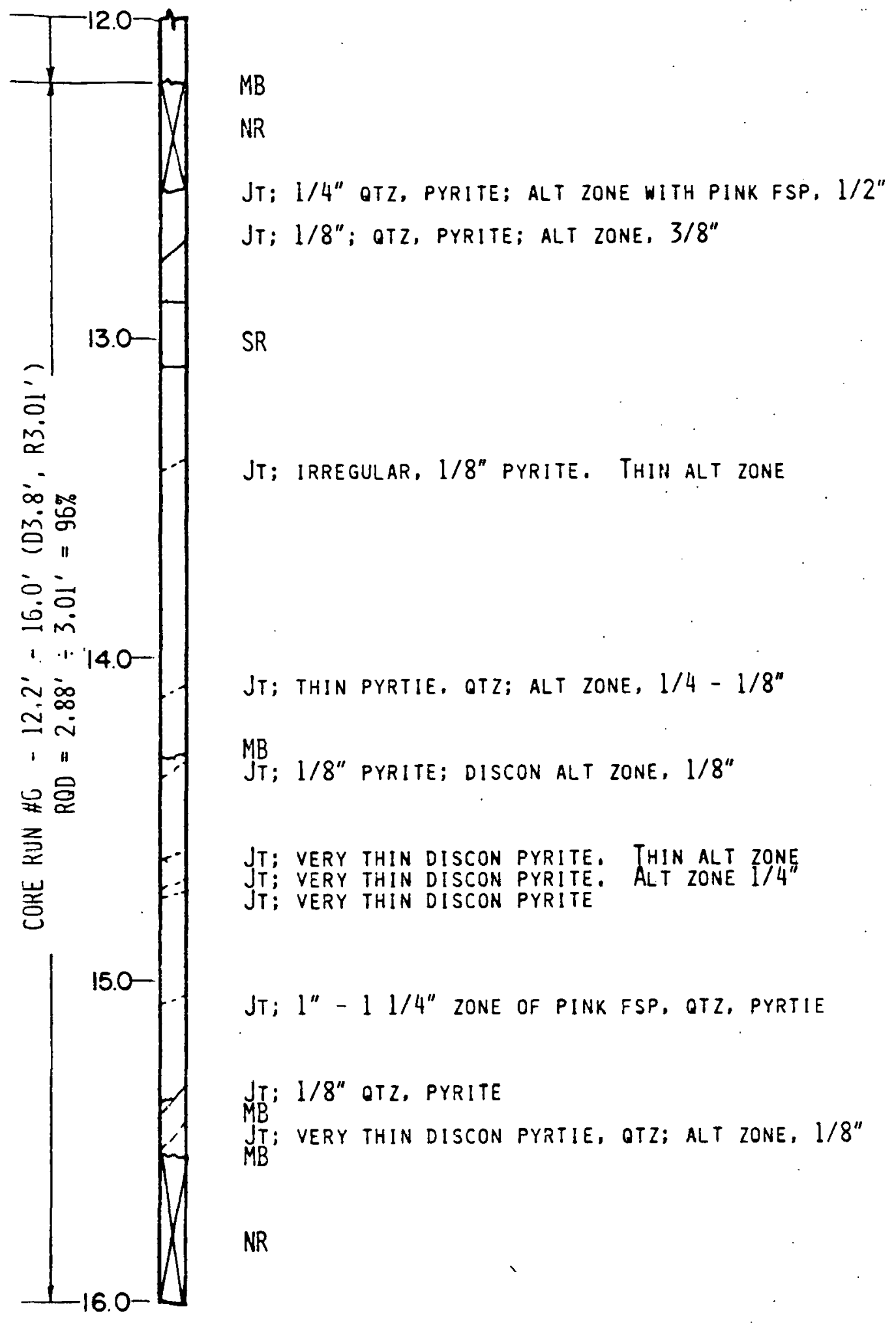

FIG. B-10d (NHH-10) 


\section{DISCLAIMER}

This document was prepared as an account of work sponsored by an agency of the United States Government. Neither the United States Government nor the University of California nor any of their employees, makes any warranty, express or implied, or assumes any legal liability or responsibility for the accuracy, completeness, or usefulness of any information, apparatus, product, or process disclosed, or represents that its use would not infringe privately owned rights. Reference herein to any specific commercial products, process, or service by trade name, trademark, manufacturer, or otherwise, does not necessarily constitute or imply its endorsement, recommendation, or favoring by the United States Government or the University of California. The views and opinions of authors expressed herein do not necessarily state or reflect those of the United States Government thereof, and shall not be used for advertising or product endorsement purposes.

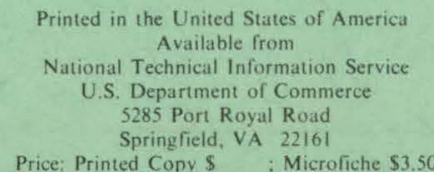

\begin{tabular}{|c|c|c|c|}
\hline Page Range & $\begin{array}{c}\begin{array}{c}\text { Domestic } \\
\text { Price }\end{array} \\
\end{array}$ & Page Range & $\begin{array}{c}\begin{array}{c}\text { Domestic } \\
\text { Price }\end{array} \\
\end{array}$ \\
\hline $001-025$ & $\$ 5.00$ & $326-350$ & $\$ 18.00$ \\
\hline $026-050$ & 6.00 & $351-375$ & 19.00 \\
\hline $051-075$ & 7.00 & $376-400$ & 20.00 \\
\hline $076-100$ & 8.00 & $401-425$ & 21.00 \\
\hline $101-125$ & 9.00 & $426-450$ & 22.00 \\
\hline $126-150$ & 10.00 & $451-475$ & 23.00 \\
\hline $151-175$ & 11.00 & $476-500$ & 24.00 \\
\hline $176-200$ & 12.00 & $501-525$ & 25.00 \\
\hline $201-225$ & 13.00 & $526-550$ & 26.00 \\
\hline $226-250$ & 14.00 & $551-525$ & 27.00 \\
\hline $251-275$ & 15.00 & $526-550$ & 28.00 \\
\hline $276-300$ & 16.00 & 601-up 1 & \\
\hline $301-325$ & 17.00 & & \\
\hline
\end{tabular}

${ }^{1}$ Add 2.00 for each additional 25 page increment from 601 pages up. 
